\title{
Deep Tests in Denmark 1935-1959
}

by

Theodor Sorgenfrei and Arne Buch

Dansk sammendrag:

Dybdeboringer i Danmark

1935-1959

With 22 Plates

I kommission hos

C. A. REITZELS FORLAG (JøRGEN SANDAL)

KØBENHAVN 1964 
DANMARKS GEOLOGISKE UNDERSØGELSE

III. RÆKKE . NR. 36

Geological Survey of Denmark . III. Series . No. 36

\section{Deep Tests in Denmark \\ 1935-1959}

by

Theodor Sorgenfrei and Arne Buch

Dansk sammendrag

Dybdeboringer i Danmark

1935-1959

With 22 Plates

I kommission hos

C. A. REITZELS FORLAG (JØRGEN SANDAL)

København 1964 


\section{PREFACE}

Work on this report on the first period of oil exploration in Denmark was started in 1959 as requested by Dr. H. ØDUM, Director of the Geological Survey of Denmark. In that year the Danish American Prospecting ComPANY relinquished the concession of Denmark and submitted the final portion of exploration data and well sample material to the Geological Survey of Denmark in accordance with the concession.

Completion of the report was, however, delayed for various reasons. The main cause was the transfer of the senior author from the Geological Survey to the Technical University of Denmark in 1961.

By forwarding the report the writers want to emphasize its preliminary nature. The large amount of sample material derived from the wells drilled during the exploration programme is under current study at the Geological Survey. A team of geologists of which the writers are members was organized in 1959 for a careful re-study in detail of lithology, biostratigraphy, tectonics, etc. of the deep subsurface of Denmark.

The work of this team did already result in new knowledge and concepts, which may alter our ideas of the geology in the future. It might, therefore, have been more sensible to postpone the present report. This was, however, deemed inadvisable because of the need for information on the deep tests drilled in Denmark and the fact that the final monographs may keep the public waiting for a while.

Geology is not only taught at the universities, but also at high schools and teachers colleges in our country. Students and teachers have accordingly waited for a report on the geological results of the exploration for many years. The interest of the international public is also of a vivid nature. Denmark is situated in a strategic position from a geologic point of view. It connects the Precambrian basement shield of Fennoscandia with the sedimentary basin of Northern Germany, and it is a link between West and East in Northern Europe.

By preparing this report it has been attempted to meet some of the wishes both of Danes and foreigners. Since it was assumed that the interests of the two groups are not identical, the English and Danish texts are somewhat different.

An apology to the reader for deficiencies and inconsistencies. 
The writers are indebted to Mrs. Rigmor Borg, J. A. Troels-Smith, Ph. D., Gunnar Jansson, M. Sc. and Mr. Chr. WestergaArd for substantial aid during the preparation of the plates. Finally the members of the Team on the Subsurface Geology of Denmark are gratefully acknowledged for valuable discussions and contribution of material for publication.

December 1963

Theodor Sorgenfrei

Institute for ApPlied GeOlogy

TeChNical University OF DenMark

Lyngby
Arne Buch

Geological Survey of DenMark Charlottenlund 


\section{CONTENTS}

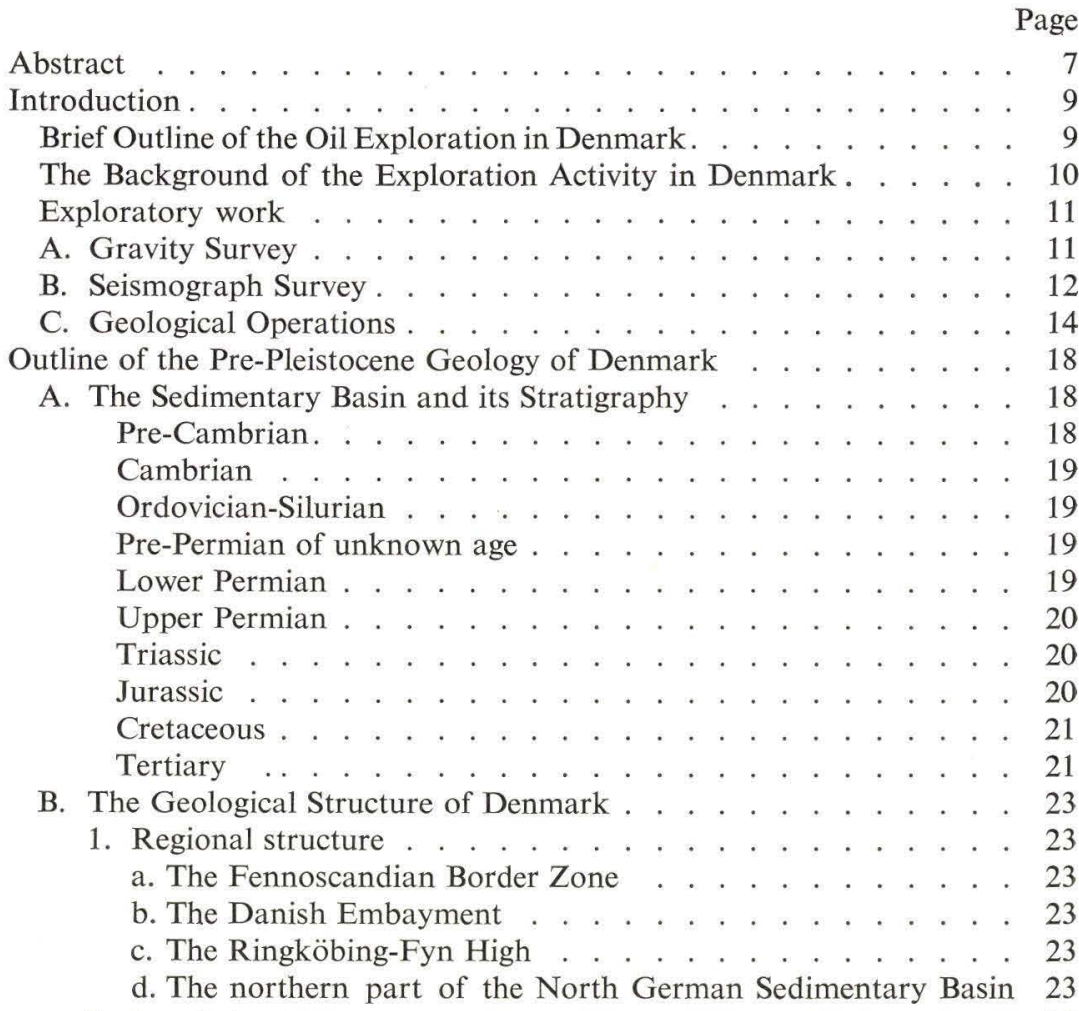

2. Local structure . . . . . . . . . . . . . . . 24

a. The Fennoscandian Border Zone . . . . . . . . . . . . 24

b. The Danish Embayment . . . . . . . . . . . . . . . . 24

c. The Ringköbing-Fyn High . . . . . . . . . . . . . . . 24

d. The northern part of the North German Sedimentary Basin 24

C. Hydrocarbons . . . . . . . . . . . . . . . . . . . . . . . 24

The Drilled Sections and their Stratigraphic Subdivision. . . . . . . . 26

Danish Summary (Dansk Sammendrag). . . . . . . . . . . . . . . 91

Annex: Information on the species of the fossil fauna (Danish). . . . . 103

Foraminifera . . . . . . . . . . . . . . . . . . 103

Graptolithina . . . . . . . . . . . . . . . . . 130

Pelecypoda . . . . . . . . . . . . . . . . . . . 130

Ammonoidea . . . . . . . . . . . . . . . . . . . . . . 137

Belemnites. . . . . . . . . . . . . . . . . . . 140

Literature . . . . . . . . . . . . . . . . . . . . . . . . . 141

Foraminifera . . . . . . . . . . . . . . . . . . . . . . . . . 141

Graptolithina, Mollusca . . . . . . . . . . . . . . . . . . 143

Borings . . . . . . . . . . . . . . . . . . . 145

Plates 1-22 (13-22 unbound in cover pocket) 


\begin{abstract}
The exploration activity which resulted in the 31 deep tests reported on in this paper is briefly outlined in the introductory chapter.

Mr. F. RavLIN initiated exploration by drilling the two wells at Harte. $\mathrm{He}$ held the concession covering all of Denmark from 1935 to 1938, when GuLF Oil CORPORATION acquired the concession. A large amount of geophysical and geological work was subsequently carried out under the aegis of the GULF OIL Corporation, and until 1957 eighteen deep tests were completed. Finally, during the period from 1957 to 1959, when the STAndard Oil Company of NEW JeRSEY was the concessionaire, seismic work was carried out in selected areas, and 11 deep tests were drilled.

Among the geological results the most important one was the proof of a well developed Pre-Upper Cretaceous sedimentary basin in Denmark. The rock column includes Pre-Cambrian, Cambrian, Ordovician, Silurian, Permian, Triassic, Jurassic, and Lower Cretaceous formations. A thick evaporite sequence in the Upper Permian Zechstein is the prerequisite of the salt dome province discovered in North Jutland.

Oil shows were encountered in dolomites of the Zechstein in South Jutland, but these petroliferous beds proved unproductive. A short blow out of petroleum gas was, moreover, experienced while drilling in the Suldrup salt dome in North Jutland. It is assumed, that a Zechstein dolomite was the reservoir.

An abbreviated well log is given for each of the 31 deep tests. Graphic logs of the wells arranged into simple cross sections are found on plates 18 to 22 . Bibliographic references regarding fossil species of importance for biostratigraphy are given in the Danish annex at the end of the paper. Most of the species concerned are illustrated on plates 1 to 11 .
\end{abstract}




\section{INTRODUCTION}

\section{BRIEF OUTLINE OF THE OIL EXPLORATION IN DENMARK}

The history of oil exploration in Denmark has partly been dealt with by Hilmar Ødum (1960) in his paper on the salt exploration. The main events in the history of the prospecting for hydrocarbons in Denmark were otherwise as follows:

In January 1935 the Danish Government granted to Mr. Fred Ravlin, a U.S. citizen, an exclusive right to prospect for all undiscovered minerals in Denmark (except for the Faroe Islands and Greenland). The Danish American Prospecting Co. was subsequently formed by Mr. RavLin, and the first two tests for oil and natural gas, Harte No. 1 and No. 2, were drilled in Jutland during the period July 1935 till April 1938. Both holes were dry. Partly before and partly while these drillings were carried out a very limited amount of geophysical work, including magnetometer, gravimeter, and refraction seismograph surveys, was carried out.

In August 1938 the Danish American Prospecting Company and the Danish concession was taken over by Gulf Refining Company (Gulf Oil Corporation, Pennsylvania, U.S.A.) Shortly thereafter the Danish American Prospecting Company commenced extensive exploratory activities in Denmark. A detailed gravimeter survey was started in September 1938, seismograph operations were initiated in June 1939, and drilling of stratigraphic tests and structure core holes with a Sullivan rig began in the fall of 1939. Moreover, various geological surveys and studies were in progress.

All operations were suspended, when the German army invaded Denmark on April 9, 1940.

Early in 1946 operations were resumed. Drilling of structure core holes on gravity features suggesting salt domes was continued with the Sullivan rig. Furthermore an Emsco J-750 rig and a Cardwell model " $R$ "'-rig were brought into Denmark. The first deep test with the Emsco rig, Vinding No. 1, was started in July 1947. The Cardwell rig was put in operation on the Suldrup salt dome in September the same year. The rigs are shown on plate 12 .

The gravity survey was completed in July 1948, and the seismic surveys were continued until October 1953.

Drilling activity was going on almost uninterruptedly till October 1953 . The Sullivan rig was drilling structure core holes and core holes in the salt domes. 
Similarly the Cardwell rig was included in both the salt prospecting programme and structure drilling. Moreover, a number of semi deep tests and stratigraphic tests were drilled with the Cardwell rig. Only 5 deep tests were completed with the Emsco rig.

The Gassum No. 1 deep test was standing idle from February 1949 to December 1950 during a period of negotiations, when concession matters were discussed with the Danish Government. Drilling with the Cardwell rig was also suspended during this period.

Since June 2, 1950, operations were carried out under a new concession signed by King Frederik IX the said date.

Due to the discouraging results of the exploration efforts it was decided to suspend field operations on February 1, 1954. Interpretation and compilation work was, however, continued on a small scale. Structure drilling was resumed with a Failing 1200 rig in January 1956. Shortly afterwards the drilling of seismic shot holes was started.

On May 13, 1957, Standard Oil of New Jersey took over the Danish American Prospecting Company and resumed operations on a full scale under a new concession from which salt deposits were excluded.

Two seismic crews were active from July to December 1957, and one of the crews continued work until December 1958. Eleven wildcats were drilled from December 1957 to May 1959 with an Emsco 800 rig (see plate 12). All wells were, however, dry holes, and the concession was finally given up on June 30 , 1959 .

THE BACKGROUND OF THE EXPLORATION ACTIVITY IN DENMARK

When the Danish American Prospecting Company initiated its exploration activity in Denmark a number of small oil fields had been found south of the country in Northern Germany. The northernmost of these fields, the Heide field, was situated only about $80 \mathrm{~km}$. south of the Danish-German frontier.

Actual data on the pre-Upper Cretaceous formations in Denmark were lacking. However, there were good reasons to assume conditions similar to the ones prevailing in Northern Germany. Saline ground water suggested the presence of salt deposits at depth, and the geophysical surveys of the Geological Survey of Denmark and the Danish Geodetic Institute which included magnetic, gravimetric and seismic surveys, and were initiated in 1929, indicated interesting structural features.

Except for minor occurrences of methane gas in Pleistocene interglacial sands in Vendsyssel and in the smaller islands south of Fyn no significant seepages of hydrocarbons were known from Denmark.

The first goal of the exploration was accordingly to provide a sufficient amount of data for an appraisal of the subsurface geology of Denmark. 
Interests were particularly concentrated on the potential extension of the petroliferous formations as known from the adjacent parts of Germany. Since it was generally agreed that the oil and gas produced from the dolomites of the Upper Permian Zechstein in Germany was indigenous, the Zechstein became the main objective formation for drilling.

Discoveries in Germany after World War II demonstrated the importance of the sands in the Lower Cretaceous and Jurassic as oil reservoirs. Potential sands in the pre-Upper Cretaceous Mesozoic formations of Denmark were consequently also included as drilling objectives in the exploration programme.

\section{EXPLORATORY WORK}

\section{A. GRAVITY SURVEY}

The whole country except of Bornholm was surveyed with the Gulf gravimeter, and Bouguer Anomaly maps to the scale of 1:100.000 were constructed. By figures the survey may be illustrated as follows.

Start of survey: September 26, 1938.

Suspension period during World War II: April 12, 1940 to August 20, 1946. Completion of survey: July 6, 1948.

Total party months: 53.

Total number of stations: 18.682.

Area surveyed: $42.200 \mathrm{~km}^{2}$.

Average station spacing: $\quad 2.26 \mathrm{~km}^{2}$.

Average station grid: $1.5 \mathrm{~km}$.

Probable error of single observation: $\quad 0.03$ milligal. Probable error of Bouguer values: $\quad 0.06$ milligal.

The Bouguer gravity results were interpreted by Dr. Sigmund HAMmer of the Gulf Research and Development Company. Dr. Hammer finally also constructed and interpreted a Residual Gravity Map to the scale of 1:100.000.

It appeared that the gravimeter was a very useful reconnaissance tool under the geological conditions prevailing in Denmark. Significant gravitational features were outlined on the maps (plates 14-16).

A salt dome province was discovered in North Jutland. It was characterized by rather distinct gravity anomalies, the most conspicuous features being the round deep gravity minima over the piercement salt domes. The RingköbingFyn Regional High, on the other hand, appeared as a system of NNW-SSE trending, relatively sharp, local gravity highs suggesting shallow basement horsts and intervening narrow grabens. The gravity anomalies in the transition belt between the salt dome province and the Ringköbing-Fyn High were less well defined and, accordingly, more difficult to interpret. 
South of the Ringköbing-Fyn High the extension of the North German Salt Dome Province was outlined by local sharp gravity lows extending southward into Germany from the east coast of South Jutland.

Central Sjælland was characterized by broad, approximately N-S trending features, while more anomalous conditions seemed to prevail in Southern Sjælland. A relatively pronounced maximum was located in the northwestern region of the island.

Interpretation of the gravity results was generally based on all available geological data, published as well as unpublished ones. It was of considerable importance in this context that the Well Files of the Geological Survey were accessible, and that the current results of research on the subsurface carried out by the staff of the Geological Survey were at the disposal of the exploration company.

\section{B. SEISMOGRAPH SURVEY}

Refraction surveys were carried out by one party in the North Jutland Salt Dome Province before World War II from June 1939 till April 1940. This work was resumed in June 1946.

The gravity lows of the North Jutland Salt Domes were mainly surveyed until October 1947, whereby the refraction shooting yielded reasonably good results. The situation changed, however, when the less contrasting structures of South Jutland were examined. It was hardly possible to get a clear picture of the structural situation by means of the refraction method in this region. From 1947, therefore, reflection shooting became the rule, and refraction shooting was only carried out occasionally in regions with shallow high speed material and for the purpose of velocity shooting.

Large areas of Jutland, Southwestern Sjælland, and Lolland were successively surveyed with reflection shooting from November 1947 to November 1953. Two crews were in operation from September 1951 to February 1953 while one crew was working during the remaining time.

A total of 114 party months had been completed from June 1939 to April 1940 and from June 1946 to October 31, 1953. It amounted to $5.148 \mathrm{~km}$. of profiles corresponding to ca. $45 \mathrm{~km}$. per party month.

The last period of seismic work covered the time from July 10, 1957 to December 20, 1958 while Standard Oil of New Jersey had the concession. Two parties were in operation from July 1957 to January 1958, and only one crew worked from January to December 1958.

A total of 24 party months were spent, and $1386 \mathrm{~km}$. of seismic profiles were completed. This corresponds to $57.7 \mathrm{~km}$. per party month. Only reflection shooting was carried out during this period.

Reflection horizons. Various reflection horizons were experienced in the 
subsurface of Denmark during the seismic work. The following were the most persistent ones:

1. Base of the Tertiary. This horizon is obviously related to the velocity contrast between the Tertiary clays and shales, and the underlying Danian limestone. The horizon has not been contoured during the seismic survey.

2. Base of the Upper Cretaceous. It is the most caracteristic reflection horizon of Denmark which was generally referred to as the "Top of the Lower Cretaceous". It is, however, obviously closely related to the indurated limestone horizon found at the base of the Upper Cretaceous, somewhat above the boundary to the Lower Cretaceous. This horizon has generally been used as a marker horizon in the structure mapping.

3. Top of the Middle Keuper. This horizon was simply called "Top of Keuper" on the understanding that the lithology of the overlying Rhaetic of the Upper Keuper belongs to a different cycle and forms the basal part of the sedimentary sequence otherwise referred to the Jurassic.

The reflection horizon may practically be identical with the boundary between the shale-sandstone sequence of the Rhaetic and the more or less massive claystones and marlstones of the Middle Keuper.

4. Top of the Upper Permian Zechstein Salt. The marked velocity change at the boundary between the sandstones and siltstones of the basal Triassic (Bunter) and the rock salt of the Zechstein produces this reflection horizon. It has locally been a useful marker horizon by the structure mapping.

5. Top of the C 3-Dolomite of the Zechstein evaporite sequence. It represents the velocity change between the thick $\mathrm{C}$ 5-Rock Salt interval (including the basal C 4-Anhydrite) and the underlying C 3-Dolomite. It generally was the deepest reflection horizon which was occasionally recognized in areas with a thick salt sequence.

6. Top of Pre-Cambrian Basement. In areas outside the salt basins i.e. on the Ringköbing-Fyn High and the Vendsyssel area it was occasionally possible to obtain reflections from the top of the basement.

Presentation of seismic results. During the operations of the Gulf Oil Corporation the seismic results were obtained as conventional records from which reflection times and depths were calculated. Seismic cross sections and contour maps showing significant reflection horizons were elaborated on the basis of these data. Interpreters were: A. H. MAC KeE, H. MAC Grew, P. JENSEN and J. RoBINSON.

When the Standard Oil of New Jersey started its survey in 1957 the newly invented variable-density-film method was used, and contour maps based on reflection time were drafted. Interpretation work was carried out by J. C. Johnson, M. C. Hogue, R. Slettene and M. Spaeth. 


\section{GEOLOGICAL OPERATIONS}

The efforts were initially concentrated upon the establishment of a biostratigraphic subdivision of the marine intervals of the rock column encountered during the drilling programme which included the core holes listed in table 1 below and the deep tests in table 3, p. 27. The non fossiliferous parts of the column were subdivided in accordance with their lithologies, electrical properties, or chemical-mineralogical composition. An adequate geological interpretation of the structure of the areas covered by the geophysical investigations was simultaneously attempted by correlation of geological maps and cross sections with corresponding geophysical data.

Regional studies of paleogeography, occurrence of hydrocarbons, sedimentary basins, structure etc. were also carried out, and paleogeographic maps of various types were compiled.

The coverage with deep drill holes was relatively good in South Jutland and Vendsyssel while there are rather large unexplored areas in Central Jutland and the islands as far as the deeper pre-Upper Cretaceous formations are concerned. Nowhere, for instance, has the evaporite sequence of the Zechstein been penetrated in the North Jutland Salt Basin, and the deep tests south of the Ringköbing-Fyn High stopped in the Lower Permian Rotliegend formation.

The well logs of the 31 most important deep and semi-deep tests are found on pages 28-90. The geological results of the wells represent an immense increase of the knowledge of the geology of Denmark. Formations older than the Upper Cretaceous were known before only from Bornholm where lower Paleozoic and Mesozoic formations are exposed. No well had penetrated the Upper Cretaceous in Jutland and the islands west of the Öresund prior to the drilling of the Harte well which stopped in the Triassic.

The following brief outline of the geological setting of Denmark includes the most significant new concepts derived from the geological and geophysical results of the exploration activity until 1958 .

The locations of the core holes and the deep tests are shown on the map plate 17 .

TABLE 1

STRUCTURE CORE HOLES AND SALT EXPLORATION

CORE HOLES DRILLED IN DENMARK FROM 1939-1952

\begin{tabular}{lcccl} 
Structure & Well No. & $\begin{array}{c}\text { D.G.U. Well } \\
\text { File No. }\end{array}$ & $\begin{array}{c}\text { Final } \\
\text { Depth }\end{array}$ & Formation \\
\hline Batum* & 1 & 38.136 & $162.5 \mathrm{~m}$ & Cap Rock \\
- & $1 \mathrm{~A}$ & 38.137 & $762-$ & Rock Salt \\
- & 2 & 38.150 & $66.5-$ & Pleistocene \\
- & 3 & 38.149 & $763-$ & Rock Salt \\
- & 4 & 46.169 & $471-$ & Senonian \\
- & 5 & 38.139 & $521-$ & Rock Salt \\
* Salt structure. & & & &
\end{tabular}




\begin{tabular}{|c|c|c|c|c|}
\hline Structure & Well No. & $\begin{array}{l}\text { D.G.U. Well } \\
\text { File No. }\end{array}$ & $\begin{array}{l}\text { Final } \\
\text { Depth }\end{array}$ & Formation \\
\hline Batum* & 6 & 38.140 & $388.5-$ & Rock Salt \\
\hline- & 7 & 38.141 & $491.5-$ & Rock Salt \\
\hline - & 8 & 38.142 & $361 \mathrm{~m}$ & Rock Salt \\
\hline - & 9 & 38.143 & $553-$ & Rock Salt \\
\hline - & 10 & 46.170 & $370.5-$ & Rock Salt \\
\hline - & 11 & 38.144 & $204-$ & Rock Salt \\
\hline - & 12 & 38.145 & 196 & Rock Salt \\
\hline - & 13 & 38.146 & 622 & Rock Salt \\
\hline - & 14 & 38.147 & 254 & Cap Rock \\
\hline - & 15 & 38.148 & 457 & Rock Salt \\
\hline - & 16 & 38.151 & 606 & Rock Salt \\
\hline- & $16 \mathrm{~A}$ & 38.152 & 207 & Rock Salt \\
\hline Draaby* & 1 & 31.23 & 183 & Pleistocene \\
\hline $\mathrm{Eg}$ & 1 & 113.31 & 316 & Danian \\
\hline- & 2 & 113.32 & $320-$ & Danian \\
\hline - & 3 & 103.60 & $423.5-$ & Danian \\
\hline- & 4 & 104.948 & $378-$ & Danian \\
\hline Egholm & 1 & 26.172 & $469.5-$ & Lower Cretaceous \\
\hline- & 2 & 26.173 & $63-$ & Upper Cretaceous \\
\hline- & $2 \mathrm{~A}$ & 26.173 & $473.5-$ & Lower Cretaceous \\
\hline Fjerritslev* & 1 & 24.23 & $182.5-$ & Senonian \\
\hline Frederikshavn & 1 & 11.170 & $380.5-$ & Lower Cretaceous \\
\hline- & 2 & 7.676 & $352-$ & Lower Cretaceous \\
\hline - & 3 & 7.681 & $338.5-$ & Lower Cretaceous \\
\hline - & 4 & 11.171 & $388.5-$ & Lower Cretaceous \\
\hline- & 5 & 7.686 & $337-$ & Lower Cretaceous \\
\hline - & 6 & 7.683 & 334 & Lower Cretaceous \\
\hline - & 7 & 7.684 & 380 & Lower Cretaceous \\
\hline- & 8 & 7.685 & 334 & Lower Cretaceous \\
\hline Gamborg & 1 & 135.53 & 189 & Senonian \\
\hline- & 2 & 135.52 & 219 & Senonian \\
\hline- & 3 & 134.228 & $177-$ & Senonian \\
\hline - & 4 & 134.227 & $160.5-$ & Senonian \\
\hline - & 5 & 135.54 & $223-$ & Pleistocene \\
\hline - & 6 & 135.55 & $203-$ & Senonian \\
\hline- & 7 & 134.226 & $158.5-$ & Danian \\
\hline Harboöre* & 1 & 43.19 & $762-$ & Rock Salt \\
\hline Hem & 1 & 49.76 & 87 & Pleistocene \\
\hline- & $1 \mathrm{~A}$ & 49.76 & 115 & Senonian (?) \\
\hline- & 2 & 49.77 & 75 & Danian \\
\hline Herning* & 1 & 84.778 & 126 & $\begin{array}{l}\text { Pleistocene (and } \\
\text { Cap Rock?) }\end{array}$ \\
\hline Hvidbjerg* & 1 & 44.140 & $685.5-$ & Lower Cretaceous \\
\hline Hvornum* & 1 & 57.134 & $564-$ & Rock Salt \\
\hline Höjrup & 1 & 125.254 & $199.5-$ & Danian \\
\hline- & 2 & 125.255 & $187.5-$ & Danian \\
\hline - & 3 & 125.253 & $224.5-$ & Danian \\
\hline - & 4 & 134.225 & $183-$ & Danian \\
\hline Jerslev & 1 & 17.83 & $699.5-$ & Lower Cretaceous \\
\hline Klelund & 1 & 123.18 & $315.5-$ & Danian \\
\hline- & 2 & 123.19 & $394-$ & Danian \\
\hline - & 3 & 124.21 & $332.5-$ & Danian \\
\hline Langstrup & 1 & 187.133 & $223.4-$ & Senonian \\
\hline- & $2 \mathrm{~B}$ & 187.134 & $286.8-$ & Senonian \\
\hline Legind* & 1 & 29.213 & $183-$ & Upper Cretaceous \\
\hline Lyngby & 1 & 8.21 & $556.5-$ & Lower Cretaceous \\
\hline Lögstör & 1 & 39.302 & 185 & Upper Cretaceous \\
\hline- & 2 & 32.537 & $183.5-$ & Upper Cretaceous \\
\hline Mönsted* & 1 & 65.179 & $762-$ & Rock Salt \\
\hline
\end{tabular}

\footnotetext{
* Salt structure
} 


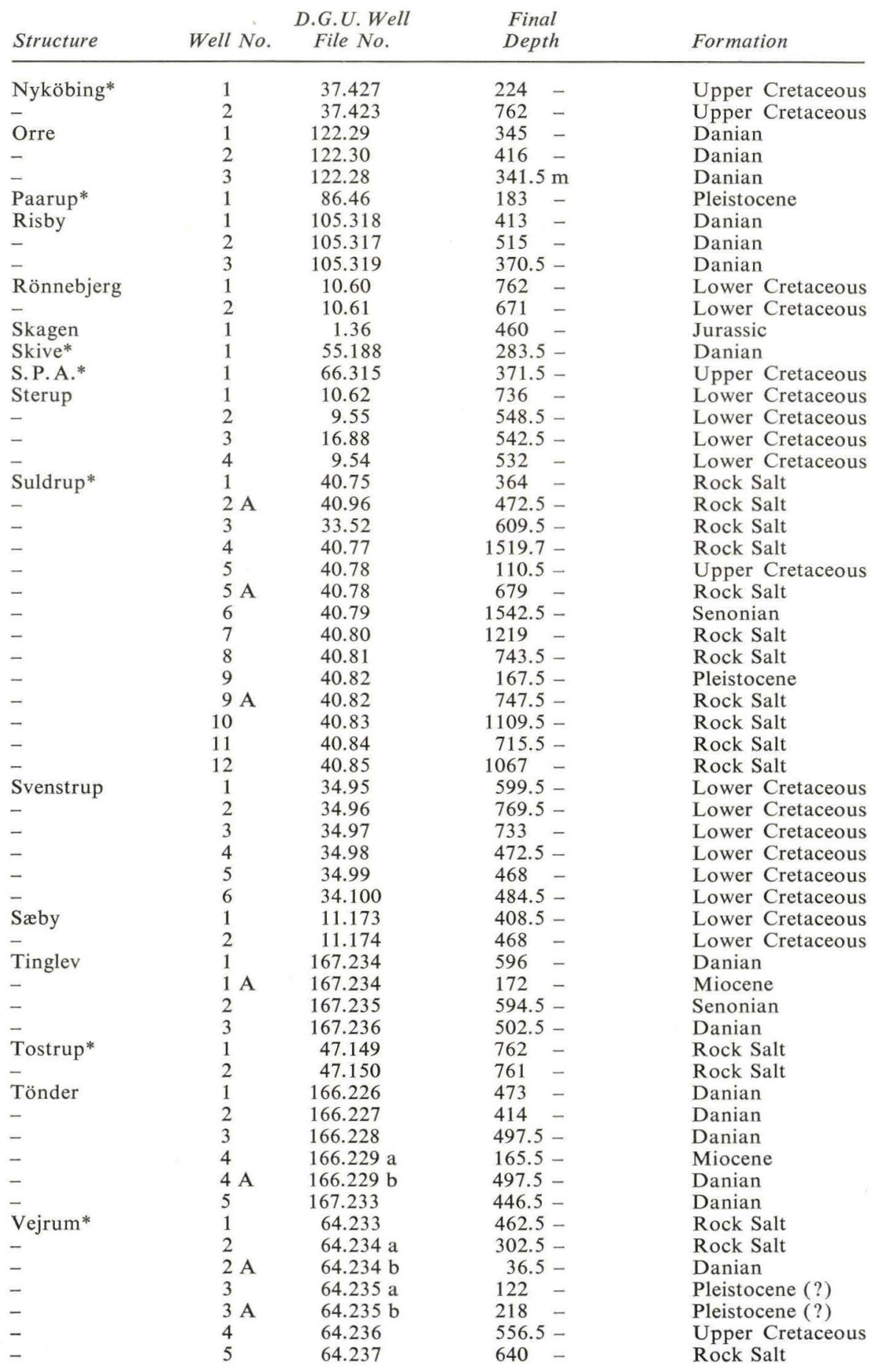

* Salt structure 


\begin{tabular}{lcccl} 
Structure & Well No. & $\begin{array}{c}\text { D.G.U.Well } \\
\text { File No. }\end{array}$ & $\begin{array}{c}\text { Final } \\
\text { Depth }\end{array}$ & Formation \\
\hline Vejrum* & 6 & 64.238 & $548-$ & Lower Cretaceous \\
Viborg & 1 & 66.318 & $489.5-$ & Danian \\
- & 2 & 66.317 & $318.5-$ & Eocene \\
- & 3 & 56.192 & $350.5-$ & Paleocene \\
- & 4 & 56.191 & $323 \mathrm{~m}$ & Paleocene \\
- & 5 & 56.190 & $319.5-$ & Danian \\
- & 6 & 66.316 & $189.5-$ & Oligocene \\
Vraa & 1 & 9.52 & $560.5-$ & Lower Cretaceous \\
- & 2 & 9.49 & $524.5-$ & Lower Cretaceous \\
- & 3 & 9.51 & $510.5-$ & Lower Cretaceous \\
- & 4 & 9.53 & $526-$ & Lower Cretaceous \\
Vrensted & 1 & 9.50 & $73.5-$ & Pleistocene \\
- & 1 & 9.50 & $576-$ & Lower Cretaceous \\
Ödsted & 1 & 124.22 & $289.5-$ & Danian \\
Öster Halne & 1 & 26.166 & $500-$ & Lower Cretaceous \\
- & 2 & 26.167 & $471-$ & Lower Cretaceous \\
- & 3 & 26.168 & $385.5-$ & Lower Cretaceous \\
- & 4 & 26.169 & $498.5-$ & Lower Cretaceous \\
- & 5 & 26.170 & $425-$ & Lower Cretaceous \\
- & 6 & 25.55 & $550.5-$ & Lower Cretaceous \\
Öster Vraa & 1 & 10.63 & $574.5-$ & Lower Cretaceous \\
\hline
\end{tabular}

Structure Core Holes:

Salt Exploration Core Holes: 


\section{OUTLINE OF THE PRE-PLEISTOCENE GEOLOGY OF DENMARK}

\section{A. THE SEDIMENTARY BASIN AND ITS STRATIGRAPHY}

In a regional sense Denmark belongs to the Northwest European Sedimentary Basin and in this capacity it is related with southern Sweden, northern Germany, the Netherlands, and eastern England.

The Danish sedimentary basin is bordered to the east by the large Scandinavian Pre-Cambrian shield of Fennoscandia. Bed rock exposures are relatively scarce, since the Pleistocene glacial drift covers the older formations in the main part of the country. The formations at the base of the Pleistocene Glacial Drift are shown on plate 13 .

The formations shown in table 2 p. 22 have been encountered west of the Öresund in the deep tests so far drilled.

The most complete sedimentary sequence is found in the Danish Embayment which is the area of subsidence between the Fennoscandian Border Zone and the Ringköbing-Fyn High mentioned below. The High proper and the region on its southwest are generally devoid of Jurassic and thick Lower Cretaceous deposits. Another characteristic feature is the rather shallow Pre-Cambrian basement in the High.

It is not intended to give a detailed account of the stratigraphic evidence in the different wells and areas in the present case. The following report on the stratigraphic procedures applied and the distribution of the individual stratigraphic units may, however, illustrate the degree of certainty of the stratigraphic conclusions and the remaining paleogeographic problems.

Pre-Cambrian. Shallow Pre-Cambrian gneiss was encountered at $1286 \mathrm{~m}$ at Frederikshavn in northernmost Jutland, possibly on the trend of the Fennoscandian Border Zone. The gneiss is related to the basement rocks of southwestern Sweden (Noe-NygaARd 1951 and 1963).

Further south, beyond the Danish Embayment, the Pre-Cambrian of the Ringköbing-Fyn High has been reached by the Grindsted and Glamsbjerg wells at $1599 \mathrm{~m}$ and $903 \mathrm{~m}$ respectively. The rocks are metamorphic. They have recently been described by NO-NYEGAARD (1963). Reference is otherwise made to the well log descriptions. 
Cambrian. Sandstones and shales of Cambrian age are exposed on the island of Bornholm, situated in the Baltic, and in southwesternmost Sweden. Furthermore, the black shales and the subjacent sandstones encountered below the Ordovician-Silurian shales of the Slagelse well have been referred to the Cambrian on the basis of their lithology and due to their stratigraphic position below the Ordovician-Silurian beds.

To give a definite statement regarding the distribution of the Cambrian sandstone and shales on this meager evidence would be hazardous. However, it seems reasonable to assume a Cambrian sequence under the major part of Sjælland and the surrounding seas and islands. It is probable that these Cambrian deposits and corresponding beds in the Oslo region belong to one sedimentary basin. With this possibility in mind Cambrian deposits may be expected also in the northern Kattegat and parts of North Jutland.

Ordovician-Silurian. The interval of the Slagelse well referred to the Ordovician-Silurian was classified by means of its Graptolites. Related deposits are known from Bornholm, southwestern Sweden, and the Oslo region. Obviously the sequence reflects similar depositional conditions as those prevailing during the Cambrian. Environments and paleogeography were therefore probably more or less the same.

Pre-Permian of unknown age. The unmetamorphosed pre-Zechstein shales of the Hönning and Aabenraa wells are apparently non fossiliferous, and they are distinctly different from the Rotliegend redbeds of sandstones and siltstones as known e.g. from the Tönder, Böxlund, and Rödby wells. Although biozonation has thus been impossible so far it is quite reasonable to refer the pre-Zechstein shales at Hönning and Aabenraa to either the Carboniferous, the Silurian, the Ordovician, or the Cambrian. During these periods pelitic sediments were deposited in southwestern Fennoscandia and the North Sea area.

At first sight reference to the Silurian-Ordovician might appear most reasonable particularly due to the presence of beds of this age in the Slagelse deep test. However, the possibility of the shales being of Carboniferous age should not be disregarded.

Lower Permian. The red beds below the basal limestone of the Upper Permian have been referred to the Lower Permian Rotliegendes on the basis of their lithology and stratigraphic relations. Up to now Rotliegend beds are known only from the areas south and east of the Ringköbing-Fyn High. However, since lower Permian sandstones do occur in the Oslo region in Norway we may also expect Rotliegend sediments in the regions north of the High, i.e. in the Danish Embayment (see p. 18).

Of particular interest are the volcanic extrusives below the Rotliegend beds 2* 
in the Rödby well and the basaltic rocks in the Rödekro well. They are probably due to lower Permian igneous activity. As is well known such activity took place in the Oslo region and in Central Germany.

Upper Permian. The limestone at the base of the thick evaporite sequence of the upper Permian Zechstein includes Bryozoa which refer the limestone to the biozone of the Zechsteinkalk in Germany. The overlying evaporite sequence has been subdivided into five evaporite cycles (A-E) which in turn were subdivided into individual evaporite members. Lettering of the cycles start at the top of the sequence. The topmost cycles A, B and C are easily correlated with Zechstein sequences farther south in Lower Saxonia and the Harz region. The lower part of the Zechstein evaporites in Denmark, viz. the D and E cycles, differ, however, from the development of the "Werra cycle" in its type area, the Werra basin in Central Germany. The differences suggest that local basins with different evaporation history was the rule during early Zechstein time. Later, when the local basins were filled up with evaporites the precipitation became obviously rather uniform over the entire northwest European basin to judge from the persistant lithological features of the evaporites.

Triassic. As with the Permian sequence it has been necessary to rely largely on lithologic features in subdividing the series referred to the Triassic. Four major divisions are easily recognizable in the Danish Triassic: a) the Bunter, consisting of continental redbeds with an evaporite interval at the top, b) the Muschelkalk, a grey argillaceous limestone, c) the lower-middle Keuper sequence consisting of grey or varicoloured claystones and marlstones, occasionally with evaporites, and d) the upper Keuper or Rhaetic which is a series of dark, marine shales and sandstones with some limestone intervals.

On the basis of their content of Mollusca the Muschelkalk and the Rhaetic beds could, biostratigraphically, be correlated with corresponding beds in Germany. Due to the scarcity of megafossils and lack of cored intervals the correlation of the wells had, however, mainly to depend on the examination of ditch samples and electric log characters. The electro-stratigraphic zonation was very successful in view of the persistent and simple nature of the features of the electric logs. A special difficulty in the regional correlation is the lack of electric logs from the Triassic intervals of the Vinding and Gassum wells.

The Bunter and Keuper beds extend undoubtedly under the major part of the country and the adjoining seas while the Muschelkalk in its typical marine development may be restricted to the southern parts of Denmark. The Danish Triassic basin must be considered part of the large Northwest European Triassic basin.

Jurassic deposits occur mainly in the subbasin of the Danish Embayment. They include the lower Jurassic dark shales with subordinate sandstone 
intervals of the Lias, the middle Jurassic deltaic series of shales and sandstones of the Dogger, and the upper Jurassic shales and claystones with subordinate sandstones referred to as Malm.

The deposits have been subdivided and correlated biostratigraphically. The Lias shales include a relatively rich fauna of Ammonites, Mollusca and Foraminifera which have yielded excellent possibilities of biozonation. The Dogger interval is poorly fossiliferous and its biostratigraphic classification has therefore caused considerable difficulties. Foraminifera and Ostracoda have been applied.

Mollusca, and to some extent the Foraminifera, have been used in the correlation of the upper Jurassic Malm beds.

The Lias basin corresponds apparently to the region between the RingköbingFyn High and the Fennoscandian Shield. The Dogger basin is reduced in comparison with the Lias basin. Up to now Dogger beds have only been encountered in North Jutland. Malm deposits are known from Gassum and northwards to Skagen.

Several similarities exist between the development of the Lower and Middle Jurassic in Denmark, Germany and eastern England which suggest more or less close relationships of the different basins during sedimentation. However, there is no counterpart to the Northwest German evaporite basin during the Upper Jurassic in Denmark while there are relationships between the Upper Jurassic of Yorkshire and Jutland.

Cretaceous. There is a fundamental difference between the lower and the upper Cretaceous beds lithologically. In a way the shales of the Lower Cretaceous form the continuation of the Jurassic sedimentation, while the limestonechalk facies of the Upper Cretaceous represents quite different paleogeographic conditions.

The entire Cretaceous sequence is practically marine, and its biostratigraphic subdivision has not caused major difficulties due to its prolific microand megafaunas.

The lower Cretaceous sequence is relatively thick in the region of the Danish Embayment while it is much reduced in the Ringköbing-Fyn High. The upper Cretaceous chalk series form a thick cover over the whole country except for the northernmost tip of Jutland.

Tertiary. The succession of the Tertiary shales, clays and sands above the upper Cretaceous (Danian) limestone are marine except for the lignite sands and clays in the Miocene interval. The Tertiary beds have been subdivided by means of their Mollusca and Foraminifera.

The distribution of the individual formations of the Tertiary is well illustrated by the geological map of the pre-Pleistocene formations (plate 13). 
TABLE 2

OUTLINE OF FORMATIONS IN DENMARK

\begin{tabular}{|c|c|c|c|c|c|}
\hline Era & Epoch* & Approx. Age & $\begin{array}{l}\text { Stratigraphic } \\
\text { Column En }\end{array}$ & ivironment & $\begin{array}{l}\text { Approx. } \\
\text { Maximum } \\
\text { Thickness }\end{array}$ \\
\hline \multirow{14}{*}{ 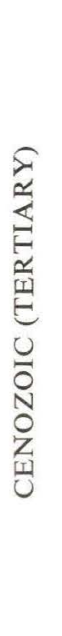 } & L. Pliocene & Pontian? & Sæd clay and sand & marine & unknown \\
\hline & U. Miocene & Sarmatian & Gram clay and sand & marine & $35 \mathrm{~m}$ \\
\hline & & & $\begin{array}{l}\text { Hodde formation, } \\
\text { clay, sand, gravel }\end{array}$ & marine & $10 \mathrm{~m}$ \\
\hline & M. Miocene & Tortonian & Odderup formation, & deltaic & $30 \mathrm{~m}$ \\
\hline & & & $\begin{array}{l}\text { sands with IIgnite } \\
\text { Arnum sands }\end{array}$ & marine & $100 \mathrm{~m}$ \\
\hline & L. Miocene & Burdigalian & $\begin{array}{l}\text { Ribe formation, } \\
\text { sands with lignite }\end{array}$ & deltaic & $100 \mathrm{~m}$ \\
\hline & & Aquitanian & Klintinghoved clay & marine & $30 \mathrm{~m}$ \\
\hline & U. Oligocene & Chattian & Cilleborg clay & \multirow{2}{*}{ marine } & $40 \mathrm{~m}$ \\
\hline & M. Oligocene & Rupelian & Branden clay & & $50 \mathrm{~m}$ \\
\hline & U. Eocene? & Exact age & Sövind marl & \multirow{4}{*}{ marine } & $20 \mathrm{~m}$ \\
\hline & M. Eocene & unknown & Lillebelt clay & & $50-60 \mathrm{~m}$ \\
\hline & & & Rösnæs clay & & $40-50 \mathrm{~m}$ \\
\hline & L. Eocene & Ypresian? & $\begin{array}{l}\text { Mo clay with } \\
\text { volc. tuff }\end{array}$ & & \\
\hline & Paleocene & $\begin{array}{l}\text { Sparnacian } \\
\text {-Montian }\end{array}$ & $\left.\begin{array}{l}\text { Kerteminde clay } \\
\text { and marl } \\
\text { Lellinge greensand }\end{array}\right\}$ & marine & $\begin{array}{r}160 \mathrm{~m} \\
10 \mathrm{~m}\end{array}$ \\
\hline \multirow{10}{*}{$\begin{array}{l}0 \\
0 \\
0 \\
N \\
0 \\
\mathscr{W} \\
\Sigma \\
\Sigma\end{array}$} & & Danian & Danian limestones & marine & $150 \mathrm{~m}$ \\
\hline & U. Cretaceous & $\begin{array}{l}\text { Senonian } \\
\text { Cenomanian }\end{array}$ & $\begin{array}{l}\text { White Chalk, marls } \\
\text { and limestones }\end{array}$ & marine & $1800 \mathrm{~m}$ \\
\hline & L. Cretaceous & $\begin{array}{l}\text { Albian } \\
\text {-Valanginian }\end{array}$ & $\begin{array}{l}\text { Clays, shales, and } \\
\text { subordinate sands }\end{array}$ & $\begin{array}{l}\text { mainly } \\
\text { marine }\end{array}$ & $400 \mathrm{~m}$ \\
\hline & U. Jurassic & $\begin{array}{l}\text { Portlandian } \\
\text {-Oxfordian }\end{array}$ & $\begin{array}{l}\text { Clays, shales, and } \\
\text { some sands }\end{array}$ & $\begin{array}{l}\text { marine and } \\
\text { deltaic }\end{array}$ & $275 \mathrm{~m}$ \\
\hline & M. Jurassic & $\begin{array}{l}\text { Callovian? } \\
\text {-Aalenian? }\end{array}$ & $\begin{array}{l}\text { Clays, shales, } \\
\text { and sands }\end{array}$ & $\begin{array}{l}\text { marine and } \\
\text { deltaic }\end{array}$ & $320 \mathrm{~m}$ \\
\hline & L. Jurassic & $\begin{array}{l}\text { Charmouthian } \\
\text {-Hettangian }\end{array}$ & $\begin{array}{l}\text { Shales and } \\
\text { some sands }\end{array}$ & $\begin{array}{l}\text { mainly } \\
\text { marine }\end{array}$ & $350 \mathrm{~m}$ \\
\hline & & $\begin{array}{l}\text { Rhaetic } \\
\text { (U. Keuper) }\end{array}$ & Shales and sands & $\begin{array}{l}\text { marine and } \\
\text { deltaic }\end{array}$ & $200 \mathrm{~m}$ \\
\hline & U. Triassic & $\begin{array}{l}\text { M. Keuper } \\
\text {-L. Keuper }\end{array}$ & $\begin{array}{l}\text { Claystones, marl- } \\
\text { stones, and locally } \\
\text { evaporites }\end{array}$ & $\begin{array}{l}\text { mainly con- } \\
\text { tinental (playa) }\end{array}$ & $410 \mathrm{~m}$ \\
\hline & M. Triassic & Muschelkalk & $\begin{array}{l}\text { Marlstones and } \\
\text { limestones }\end{array}$ & marine & $180 \mathrm{~m}$ \\
\hline & L. Triassic & Bunter & $\begin{array}{l}\text { Claystones and } \\
\text { siltstones }\end{array}$ & $\begin{array}{l}\text { mainly continen- } \\
\text { tal (playa) }\end{array}$ & $1280 \mathrm{~m}$ \\
\hline \multirow{4}{*}{ 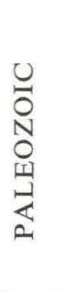 } & U. Permian & Zechstein & Rock salt, anhy- & marine and & $1020 \mathrm{~m}$ \\
\hline & L. Permian & Rotliegendes & $\begin{array}{l}\text { drite, and dolomites } \\
\text { Claystones, sand- } \\
\text { stones, conglom- } \\
\text { erates, and extrusives }\end{array}$ & $\begin{array}{l}\text { saline } \\
\text { mainly } \\
\text { continental }\end{array}$ & $260 \mathrm{~m}$ \\
\hline & $\begin{array}{l}\text { Silurian } \\
\text {-Ordovician }\end{array}$ & & $\begin{array}{l}\text { Shales, some } \\
\text { siltstone }\end{array}$ & marine & $320 \mathrm{~m}$ \\
\hline & Cambrian & & $\begin{array}{l}\text { Black shales, silt- } \\
\text { stones, and sandstone }\end{array}$ & marine & $185 \mathrm{~m}$ \\
\hline
\end{tabular}

* $\mathrm{U}=\mathrm{Upper}, \mathrm{M}=$ Middle, $\mathrm{L}=$ Lower. 


\section{B. THE GEOLOGICAL STRUCTURE OF DENMARK \\ 1. Regional structure}

a. The Fennoscandian Border Zone. A zone of block faulting with elevated basement horsts and downfaulted grabens forms the so-called Fennoscandian Border Zone between the Fennoscandian Shield and the Danish sedimentary basin. The strike of the Border Zone is about NW-SE, which is the main tectonic trend of Denmark. The Border Zone extends through Scania (southwestern part of Sweden), and the island of Bornholm is lying on its trend to the southeast. To the northwest the northernmost tip of Vendsyssel may be included in the Border Zone as suggested by the shallow Pre-Cambrian at Frederikshavn and the shallow Mesozoic at Skagen.

Locally the displacement of the Pre-Cambrian basement along the faults bordering the horsts may be on the order of $3000 \mathrm{~m}$. or more.

b. The Danish Embayment. A region of major subsidence follows southwest of the Border Zone. Its width is about $200 \mathrm{~km}$. to the north and about 125 to $150 \mathrm{~km}$. to the south. This part of the basin has been called the Danish Embayment due to its submergence during the major part of the Mesozoic. The southwestern margin of the Embayment is formed by the Ringköbing-Fyn High.

Depth to the pre-Cambrian basement may be more than $4500 \mathrm{~m}$. in the deepest parts of the basin in North Jutland, while the basement is probably somewhat shallower in the Sjælland portion of the Embayment.

In North Jutland the Salt Dome Province illustrates the structural significance of the thick rock salt sequence of the Zechstein. Here, in the central part of the Embayment, the Zechstein salt may be covered by more than $3000 \mathrm{~m}$. thick sediments of higher density than that of the rock salt, and the salt intervals may totally be 800 to $1000 \mathrm{~m}$. thick.

c. The Ringköbing-Fyn High. It is difficult to define the regional strike of this high on the basis of our present fragmentary knowledge. In lack of sufficient evidence NW-SE may be a reasonable approximation.

The southwestern flank of the high forms the border of the North German sedimentary basin. It runs from the Ribe area to the vicinity of Aabenraa where it obviously bends towards east continuing south of Fyn. The preCambrian basement is found at $1599 \mathrm{~m}$. at Grindsted and at $903 \mathrm{~m}$. at Glamsbjerg.

d. The northern part of the North German Sedimentary Basin. A very small fringe of this basin extends into South Jutland. Its tectonics include faulting, slight folding and salt flowage. 


\section{Local structure}

a. The Fennoscandian Border Zone. The local structural features of the Border Zone have been studied in exposures, mines, quarries etc. in Scania and on Bornholm. The sedimentary sequence has been block faulted and folded. Paleozoic and post Cretaceous movements and probably movements of other ages were responsible for the structural deformations and displacements.

b. The Danish Embayment. The salt flowage masks the structure of the PrePermian in this area. Otherwise the structure is dominated by the salt domes. Interdomal highs are found between some of the piercement domes. Outside the salt dome province proper low anticlines and fault structures suggest a reduced salt sequence, or shallower position of the salt than in the dome province, or a combination of both possibilities.

c. The Ringköbing-Fyn High is broken up in fault blocks which apparently moved during Triassic, Cretaceous and Tertiary times as evidenced by seismic cross sections and well sections from Fyn. The trend of the faults is apparently mainly NNW-SSE, which suggest an en échelon arrangement of the structures and shearing stresses during the tectonic movements. Horsts and grabens have developed.

The Slagelse well disclosed tilting of the Pre-Permian beds at the eastern end of the high. The movements may be either Caledonian or Variscan. This is of considerable interest, because it is the first safe evidence of Pre-Permian tectonics of Paleozoic age in the sedimentary basin of Denmark. On the southwestern border of the Ringköbing-Fyn high a pronounced angular unconformity is found between the basal Zechstein and the pre-Permian shales as evidenced by the Hönning well. The movements responsible for the dislocation may be of the same age as the ones which produced the unconformity at Slagelse.

The unmetamorphosed character of the shales at Slagelse and at Hönning speaks in favour of the Variscan revolution.

d. The northern part of the North German Sedimentary Basin. The basin extends to a line from Ribe to the vicinity of Aabenraa from where the boundary bends towards east and continues south of Fyn. Between Tönder and Flensborg we find low salt anticlines and faults while the piercement anticlines of east Sleswick extend to the isle of Als on the east coast of South Jutland.

\section{HYDROCARBONS}

The only oil shows obtained so far were encountered in the dolomites of the Zechstein in South Jutland. The rock intervals concerned and gravities of the oil were as follows: 
Aabenraa No. 1

2203-2221 m (7229'-7287') D2-dolomitic limestone, oil stained.

Gravity not determined.

This interval proved unproductive.

Tönder No. 1

2395-2401 m (7856'-7876 $)$ B3-dolomite with oil cuts, $27^{\circ}$ API

3091-3118 m (10142'-10230') C3-dolomite, oil stained, $22^{\circ}$ API

The formations were in both cases unable to produce, and the $\mathrm{C} 3$-dolomite yielded salt water on formation tests.

Tönder No. 2

2994-3019 m (9822'-9905') C3-dolomite, oil stained, $20^{\circ}$ API

The well yielded non-inflammable nitrogen gas on formation test. It is located structurally about $76 \mathrm{~m}$. (250') higher than Tönder No. 1.

The Tönder structure may be considered a monoclinal, south dipping structure at the horizon of the C3-Dolomite, whereas structural conditions at Aabenraa No. 1 are rather obscure. This well was originally drilled as a stratigraphic test and may be relatively much off-structure.

Slight fluorescence and oil cuts were encountered in the B3, C3, D9, and D3 dolomite intervals of the Hönning well.

Inflammable gas erupted from well No. 8 in the Suldrup Salt Dome while drilling at about $452 \mathrm{~m}$. (1483') in the Zechstein Salt. The gas may possibly have originated from an equivalent of the B3-Dolomite. The outflow of gas soon ceased. An analysis showed about 84 per cent methane, about 7 per cent ethane and higher hydrocarbons, and about 9 per cent nitrogen.

Another small flow of gas occurred in well No. 1 in the Tostrup Salt Dome while drilling in salt at a depht of about $513 \mathrm{~m}\left(1650^{\prime}\right)$. The composition of the gas is unknown since no sample of the gas was collected.

Minor gas shows are known from water wells lowered into the Danian Limestone in NE Sjælland. These shows are of interest since they are located in the area of the Danish Embayment. The gas may certainly not be of Upper Cretaceous origin, but may have its source in pre-Cretaceous formations. Both the Middle Mesozoic and the Zechstein may come into account in this connection.

In part of SE Sjælland, Mön and Falster the ground water from the White Chalk contains small amounts of methane. The origin of the gas is not known. Bacterial activity has been suggested. However, pre-Senonian formations may also be the source in view of the recent discovery of the Reinkenhagen oil field producing from the C3-dolomite of the Zechstein ca. $100 \mathrm{~km} \mathrm{SE}$ of the methane area. 


\section{THE DRILLED SECTIONS AND THEIR STRATIGRAPHIC SUBDIVISION}

The following description of the sequences encountered in the 31 deep tests drilled up to now represents the combined results of the efforts of the geologists of the Danish American Prospecting Company (DAPCo) and Danmarks Geologiske Undersøgelse (D.G.U) i.e. the Geological Survey of Denmark.

Each well log is preceded by a brief outline of the geophysical evidence of structure, the previous core drill results in the area, the objective of the boring, the drilling dates, and the location data. Longitude coordinates are based on the prime meridian of Copenhagen Observatory, $12^{\circ} 34^{\prime} 40^{\prime \prime} \mathrm{E}$ of Greenwich. The description of the encountered sequence summarizes the data of the individual rock intervals on the basis of examinations of ditch, bit, and core samples as reported by the well geologists of the DAPCo and the D.G.U. The stratigraphic subdivisions included in the logs were mainly inferred from paleontological evidence as brought about by the work of the paleontologists of the DAPCo as well as the D.G.U. All depth figures indicate depth below ground elevation and not below rotary table! Graphic logs are found on plates 18-22, and the locations of the wells are shown on the map plate 17.

The most significant fossils are indicated at the rock intervals. A short outline in Danish including important bibliographic references and the specific characters and stratigraphic significance of the individual species is given in the majority of species in the last chapter of the present paper. The writers have attempted to unify the systematic nomenclature, which underwent changes in several cases during the period from the start of drilling operations until the termination of the manuscript.

Most borings were logged electrically, and the sequences were currently correlated on the basis of their lithologic, biostratigraphic, and electric log features as the wells were completed. A re-study and control of the original correlations by the writers resulted in a number of stratigraphical amendments which are included in the log descriptions below.

It should be mentioned that drilling was much faster in the deep tests drilled from 1957 and onwards than in the ones drilled before 1957. The possibilities of identification of formations were accordingly relatively poor in the wells drilled after 1957 because of the long intervals from which the cuttings of the 
ditch samples originated. The lithology is therefore less specified in the tests drilled after Jan. 1, 1957. The following list relating the borings to this date is given for the reader's guidance:

TABLE 3

DEEP TESTS

DEEP TESTS DRILLED BEFORE JANUARY 1, 1957

1. (A) By Mr. F. Ravlin:

$\begin{array}{lllll}\text { Harte } & \text { No. } 1.51) \text { Harte } & \text { (p. } 5 \text { (p. 52) }\end{array}$

2. (B) By Gulf Oil Corporation:

$\begin{array}{llllll}\text { Aabenraa } & \text { No. } 1 . & \text { (p. 28) } & \text { Ringe } & \text { No. } 1 . & \text { (p. 60) } \\ \text { Arnum } & \text { No. } 1 . & \text { (p. 32) } & \text { Rödby } & \text { No. } 1 . & \text { (p. 62) } \\ \text { Börglum } & \text { No. } 1 . & \text { (p. 35) } & \text { Rödby } & \text { No. } 2 . & \text { (p. 65) } \\ \text { Frederikshavn } & \text { No. } 1 . & \text { (p. 40) } & \text { Skagen } & \text { No. } 2 . & \text { (p. 71) } \\ \text { Frederikshavn } & \text { No. } 2 . & \text { (p. 42) } & \text { Tönder } & \text { No. } 1 . & \text { (p. 75) } \\ \text { Frederikshavn } & \text { No. } 3 . & \text { (p. 43) } & \text { Tönder } & \text { No. 2. } & \text { (p. 78) } \\ \text { Gassum } & \text { No. } 1 . & \text { (p. 45) } & \text { Uglev } & \text { No. } 1 . & \text { (p. 82) } \\ \text { Glamsbjerg } & \text { No. } 1 . & \text { (p. 47) } & \text { Ullerslev } & \text { No. } 1 . & \text { (p. 84) } \\ \text { Haldager } & \text { No. } 1 . & \text { (p. 50) } & \text { Vinding } & \text { No. } 1 . & \text { (p. 89) }\end{array}$

DEEP TESTS DRILLED AFTER JANUARY 1, 1957

3. By Standard Oil Company of New Jersey:

$\begin{array}{llllll}\text { Fjerritslev } & \text { No. } 1 . & \text { (p. 36) } & \text { Lavö } & \text { No. } 1 . & \text { (p. 59) } \\ \text { Fjerritslev } & \text { No. } 2 . & \text { (p. 37) } & \text { Rödekro } & \text { No. } 1 . & \text { (p. 69) } \\ \text { Flyvbjerg } & \text { No. } 1 . & \text { (p. 39) } & \text { Slagelse } & \text { No. } 1 . & \text { (p. 72) } \\ \text { Grindsted } & \text { No. } 1 . & \text { (p. 48) } & \text { Vedsted } & \text { No. } 1 . & \text { (p. 85) } \\ \text { Hönning } & \text { No. } 1 . & \text { (p. 54) } & \text { Vemb } & \text { No. } 1 . & \text { (p. 87) } \\ \text { Horsens } & \text { No. } 1 . & \text { (p. 57) } & & & \end{array}$

The initials of the scientists and assistants who contributed with work on lithology, paleontology, electric logs, etc. are shown at the end of each log. The following list is a key to the initials including the affiliation of the workers responsible during the drilling operations:
A. B. - Arne Buch (DAPCo and DGU)
A. D. - Arne Dinesen (DGU)
A. F. B. - Allan F. Baker (DAPCo)
A. N. - Aksel Nørvang (DAPCo)
A. N. N. - Arne Noe-Nygaard (University of Copenhagen)
E. C. - Ebbe Christensen (DAPCo)
E. S. - Erik Stenestad (DGU)
F. F. - Fridtjof Frebold (DAPCo) 
G. L. - Gunnar Larsen (DGU)

G. V. O. - Gregers Vang Olsen (DGU)

H. F. - Hans Frebold (DAPCo)

H. Ø. - Hilmar Ødum (DGU)

J. A. N. - John A. Norwood (DAPCo)

J. B. S. - Jørgen Birket-Smith (DGU)

J. E. F. - John Erdélyi Fazekas (DAPCo)

J. F. F. - John F. Forrest (DAPCo)

J. M. D. - J. M. Dorreen (DAPCo)

K. H. - Knud Højgaard (DGU)

K. J. L. - Kai Junker Larsen (DAPCo)

L. B. R. - Leif Banke Rasmussen (DGU)

L. J. A. - Lars Jørgen Andersen (DGU)

M. H. - Mogens Hoff(DAPCo)

N. V. J. - Niels Viggo Jessen (DGU)

O. B. - Ole Berthelsen (DGU)

P. H. B. - Peter H. Baadsgaard (DGU and DAPCo)

R. W. - Robert Weynschenk (DAPCo)

S. B. J. - Stig Bak Jensen (DGU)

S. M. - Sole Munck (University of Copenhagen)

T.S. - Theodor Sorgenfrei (DGU and DAPCo)

W. C. - Werner Christensen (DGU)

W. S. - Wolfgang Schott (Amt für Bodenforschung, Hannover).

\section{Aabenraa No. 1 - D.G.U. File No. 160.101.}

Gravity anomaly: Broad residual gravity maximum suggesting an uplifted basement fault block. Length NW-SE about $35 \mathrm{~km}$., width NE-SW 20 to $25 \mathrm{~km}$. The boring is located about $10 \mathrm{~km}$. NW of the crest of the gravity feature.

Seismic survey: a. Reflection. Anticlinal structure cut by a NW trending fault as indicated by a reflection horizon near the top of the Zechstein salt. Very poor, or practically no, structural control of the beds below the salt.

The boring is located about $2.5 \mathrm{~km}$. SW of the assumed fault on the downthrown block. The top of the Zechstein salt was suggested at about $5900^{\prime}$ (ca. $1798 \mathrm{~m}$.) below sea level (i.e. at a depth of 6060' or ca. $1847 \mathrm{~m}$.).

b. Refraction. A refraction survey indicated a high speed refraction marker at about 5500' (ca. $1676 \mathrm{~m}$.) below sea level. This refraction marker was assumed to be dolomite or basement.

Previous core drill results: None.

Objective: Stratigraphic test primarily designed to test the Permian Zechstein formation. The development of lithofacies in the Zechstein assumed to be favourable since Aabenraa is situated in a belt paleogeographically intermediate between the Arnum and Tönder areas. 
Location: About $5 \mathrm{~km}$. WSW of Aabenraa City and $0.5 \mathrm{~km}$. E of Aarslev village. Coordinates: $55^{\circ} 1.53^{\prime} \mathrm{N} ; 3^{\circ} 13.38^{\prime} \mathrm{W}$ of Copenhagen Observatory.

Drilling: Spudded December 11, 1952, completed July 4, 1953.

Elevation: Ground $52.7 \mathrm{~m}$. (173'). Rotary table $56.1 \mathrm{~m}$. (184').

Stratigraphy, main lithology and paleontology:

0 - 111 m. Pleistocene. Glacial drift. (Istidsdannelser).

$\left(0^{\prime}-364^{\prime}\right)$

111 - 199 m. Miocene. Quartz sand, grey, coarse grained, and Mica clay,

$\left(364^{\prime}-653^{\prime}\right)$ brown to black. (Kvartssand, gråt, grovkornet, og brunt til sort glimmerler).

199 - 340 m. Eocene. Clay, greenish grey, sticky, brown at base (Ler, fedt, $\left(653^{\prime}-1114^{\prime}\right)$ grønliggråt, forneden brunt). Vaginulinopsis decorata, Cibicides sulzensis, Eponides candidulus, Spiroplectammina carinata, Radiolaria.

340 - 388 m. Lower Eocene and Paleocene. Clay, dark grey, sticky, with $\left(1114^{\prime}-1273^{\prime}\right)$ indurated beds. (Ler, fedt, mørkegråt med hårde lag). Gaudryina hiltermanni, Pseudovalvulineria sp., Bulimina trigonalis, Bulimina aspero-aculeata, Globigerina yeguaensis.

388 - 396 m. Danian. Bryozoan limestone with chert. (Bryozokalk og flint). $(1273$ '-1297') “Discorbis" binkhorsti.

396 - 885 m. Senonian-Turonian. Chalk, white, soft, with chert. Limestone, $\left(1297^{\prime}-2894^{\prime}\right) \quad$ white, in bottom part harder with marl. (Skrivekridt med flint, og hvid kalksten, nedre del hård med mergel). Bolivina incrassata, Angulogavelinella bettenstaedti, Reussella pseudospinulosa, Pseudovalvulineria cf. lorneiana, Globorotalites michelinianus, Stensioeina exsculpta.

885 - 912 m. Cenomanian. Limestone, white, with marl. (Kalksten, hvid, (2894'-2990') med mergel). Gavelinopsis cenomanica.

912 - 921 m. Albian. Claystone, reddish brown, silty, calcareous. (Lersten, $\left(2990^{\prime}-3019^{\prime}\right) \quad$ rødlig brun, finsandet, kalkholdig). Arenobulimina sp.

921 - 942 m. ?Aptian, ?Barremian-Hauterivian. Claystone, dark greenish $\left(3019^{\prime}-3089^{\prime}\right)$ grey, calcareous. (Lersten, mørk grønliggrå, kalkholdig). Lenticulina spp., Vaginulina sp., Planularia crepidularis.

942 - 944 m. ?Valanginian. Sand, fine grained, greenish grey. (Sand, fin(3089'-3097') kornet, grønliggråt).

944 - 949 m. Rhaetic. Shale and claystone, dark greenish grey. (Skifer og (3097'-3112') lersten, mørk grønliggrå). Ostracod F.

$949-1232 \mathrm{~m}$. Keuper. Claystone, varicoloured, green, greenish grey, and $\left(3112^{\prime}-4042^{\prime}\right)$ brownish grey. Anhydrite beds and bands of sandstone. (Lersten, broget, grøn, grønliggrå og brunliggrå. Lag af anhydrit og sandsten). 
$1232-1388 \mathrm{~m}$. Muschelkalk. Interbanded and interlaminated claystone and $\left(4042^{\prime}-4555^{\prime}\right)$ limestone, argillaceous and arenaceous, greenish grey. (Skiftende lag af kalksten og lersten, grønliggrå, stedvis sandet).

$1388-1851 \mathrm{~m}$. Bunter.

$\left(4555^{\prime}-6073^{\prime}\right)$

$1388-1475$ m. Röt. Claystone, reddish brown, silty, with thin anhydritic

$\left(4555^{\prime}-4840^{\prime}\right)$ bands. (Lersten, rødligbrun, finsandet med tynde anhydritholdige bånd).

$1475-1505$ m. Röt. Claystone, greenish grey and brownish grey, inter$\left(4840^{\prime}-4939^{\prime}\right)$ bedded with anhydrite, finely crystalline, light grey. (Lersten, grønliggrå og brunliggrå, afvekslende med lag af anhydrit, finkrystallinsk, lysegrå).

1505-1522 m. Röt. Anhydrite, finely crystalline, light grey. (Anhydrit, $\left(4939^{\prime}-4994^{\prime}\right) \quad$ finkrystallinsk, lysegrå).

$1522-1533$ m. Röt. Claystone, slightly calcareous and anhydritic, greenish $\left(4994^{\prime}-5029^{\prime}\right)$ grey and brownish grey. (Lersten, svagt kalkholdig og anhydritisk, grønliggrå og brunliggrå).

1533-1566 m. Röt. Claystone, sandy, reddish brown with bands of

$\left(5029^{\prime}-5139^{\prime}\right)$ sandstone, and of dolomitic sandstone, reddish brown and greenish grey. (Lersten, sandet, rødligbrun med bånd af sandsten og af dolomitisk sandsten, rødligbrun og grønliggrå). Chara oogoniae.

$1566-1633 \mathrm{~m}$. Claystone, silty, reddish brown with greenish portions,

$\left(5139^{\prime}-5359^{\prime}\right)$ and thin bands of siltstone, reddish brown and greenish grey. Oolites (Lersten, finsandet, rødligbrun med grønlige partier og tynde bånd af finsandsten, rødligbrun og grønliggrå).

$1633-1643 \mathrm{~m}$. Claystone as above, with bands of sandstone, argillaceous

$\left(5359^{\prime}-5390^{\prime}\right)$ and calcareous. (Lersten, som ovenfor med bånd af sandsten, leret og kalkholdig).

$1643-1835 \mathrm{~m}$. Claystone and siltstone, reddish brown, with bands of $\left(5390^{\prime}-6019^{\prime}\right)$ sandstone, calcareous and micaceous. (Lersten og finsandsten, rødligbrun med bånd af sandsten, kalkholdig og glimmerholdig).

$1835-1851 \mathrm{~m}$. Claystone, variegated, interbanded, light greenish grey $\left(6019^{\prime}-6073^{\prime}\right)$ and reddish brown, slightly calcareous and anhydritic. (Lersten, broget, vekslende lys grønliggrå og rødligbrun i tynde bånd, svagt kalkholdig og anhydritisk).

1851 -2332 m. Upper Permian, Zechstein.

$\left(6073^{\prime}-7653^{\prime}\right)$

1851-1855 m. ?A8-Anhydrite, white, dense, at base about $1 \mathrm{~m}$ of Clay$\left(6073^{\prime}-6085^{\prime}\right)$ stone, dark brown. (Anhydrit, hvid, tæt. Ved basis $1 \mathrm{~m}$ tykt lag af mørkebrun lersten). 
1855-1891 m. A5-Rock salt, colourless, with anhydrite in thin bands. $\left(6085^{\prime}-6204^{\prime}\right)$ (Stensalt, farveløst, med tynde anhydritbånd).

1891 -1911 m. A4-Anhydrite, white, dense, with Rock salt from 1894 $\left(6204^{\prime}-6269^{\prime}\right) \quad 1897$ m. $\left(6214^{\prime}-6223^{\prime}\right)$. (Anhydrit, hvid, tæt, Stensalt fra 1894-1897 m).

at $1911 \mathrm{~m}$. A3-Dolomite. Abt. $60 \mathrm{~cm}$. of anhydrite with some patches

$\left(6269^{\prime}\right)$ of dolomite, brownish grey, tight. (Anhydrit, ca. $60 \mathrm{~cm}$ med dolomitiske partier, brunliggrå, tæt).

1911-1981 m. B5-Rock salt, clear to colourless, occasionally slightly $\left(6269^{\prime}-6501^{\prime}\right)$ pinkish. (Stensalt, hvidt til farveløst, stedvis let rødligt). 1981 -1983 m. B4-Anhydrite, dolomitic, dense, brownish grey. (Anhydrit, $\left(6501^{\prime}-6505^{\prime}\right)$ dolomitisk, tæt, brunliggrå).

$1983-2010$ m. B3-Dolomite, brownish grey, dense, finely laminated with $\left(6505^{\prime}-6594^{\prime}\right)$ many nodules and bands of anhydrite. Less laminated in bottom part. (Dolomit, brunliggrå, tæet, tyndt lamelleret med talrige anhydritknolde og -bånd. Mindre lamelleret forneden).

2010-2014 m. B1-Shale, dark grey to greyish black, dolomitic. (Skifer, (6594'-6608') mørkegrå til grålig sort, dolomitisk).

2014-2016 m. C8-Anhydrite, light grey, finely crystalline. (Anhydrit, lyse$\left(6608^{\prime}-6614^{\prime}\right)$ grå, finkrystallinsk).

2016-2085 m. C5-7-Rock salt, clear to colourless, at base with anhydrite. $\left(6614^{\prime}-6839^{\prime}\right) \quad$ (Stensalt, hvidt til farveløst, med anhydrit nederst).

2085-2092 m. C4-Anhydrite, dolomitic, finely crystalline, tight, slightly $\left(6839^{\prime}-6865^{\prime}\right)$ petroliferous. (Anhydrit, dolomitisk, finkrystallinsk, tæt, let olieførende).

2092-2118 m. C2-3-Dolomite and limestone, brownish grey, in middle $\left(6865^{\prime}-6949^{\prime}\right)$ part oolitic, in lower part dense and tight. $\mathrm{H}_{2} \mathrm{~S}$. (Dolomit og kalksten, brunliggrå, midterste del oolitisk, nederst tæt. Indeholder $\mathrm{H}_{2} \mathrm{~S}$ ).

2118-2121 m. D9-Dolomite, anhydritic, light brownish grey, at base $\left(6949^{\prime}-6959^{\prime}\right)$ interbedded with anhydrite. (Dolomit, anhydritisk, lys brunliggrå. Nederst skiftende med anhydritlag).

$2121-2203 \mathrm{~m}$. D4-Anhydrite, light grey, dense to coarsely crystalline. $\left(6959^{\prime}-7229^{\prime}\right) \quad$ (Anhydrit, lysegrå, tæt til grov krystallinsk).

$2203-2221 \mathrm{~m}$. D2-3-Dolomite and limestone, light brownish grey, inter$\left(7229^{\prime}-7287^{\prime}\right)$ laminated with anhydrite. Oil staining and sweating. (Dolomit og kalksten, lys brunliggrå med indlejrede anhydritlag. Let olieimprægneret. Borekernerne »sveder« olie).

2221 -2236 m. E9-Dolomite, light brownish grey, with anhydrite in bands $\left(7287^{\prime}-7336^{\prime}\right)$ and laminae of small knots. (Dolomit, lys brunliggrå med bånd og striber af småknoldet anhydrit). 
2236-2290 m. E4-Anhydrite, light grey, with dolomite, brownish grey. $\left(7336^{\prime}-7516^{\prime}\right) \quad$ (Anhydrit, lysegrå med dolomit, brunliggrå).

2290-2309 m. E3-Dolomite, greyish brown, porous, in upper part reef $\left(7516^{\prime}-7577^{\prime}\right)$ development with bryozoan colonies and crinoids, in basal parts more compact, brecciated. Galena crystals. (Dolomit, grålig brun, porøs, i øvre del revfacies med bryozokolonier og crinoider, nederst mere kompakt, breccieret. Blyglanskrystaller). Fenestrellina reticulata.

2309 -2330 m. E2-Limestone, light brownish grey, with dolomite patches. $\left(7577^{\prime}-7646^{\prime}\right) \quad$ (Kalksten, lys brunliggrå med dolomitpartier).

2330-2332 m. E1-Limestone, laminated argillaceous, varicoloured, at

$\left(7646^{\prime}-7653^{\prime}\right)$ base: Breccia of claystone, calcareous with quartz. (Kalksten, lerholdig i tynde lag, broget, nederst: lerstensbreccie, kalkholdig med kvarts).

2332 -2344 m. Pre-Zechstein. Argillite, reddish brown, faintly slated, with (?) $\left(7653^{\prime}-7689^{\prime}\right)$ quartz veins. (Argillit, rødlig brun, svagt skifret med (?) kvartsårer).

Well geologists: J.F.F.; M.H.; L.B.R.; S.B.J.; K.H.; G.V.O. Micropaleontologists: A.N.; P.H.B.

Lithology: A.N.; T.S.

Schlumberger interpreter: J.A.N.

\section{Arnum No. 1 - D.G.U. File No. 150.24.}

Gravity anomaly: Residual gravity maximum indicating a local uplifted basement fault block. Length NW-SE about $35 \mathrm{~km}$. Width NE-SW about $15 \mathrm{~km}$. The uplift is apparently bounded by parallel faults with NW-SE and N-S strikes.

The boring is located about $10 \mathrm{~km}$. S to $\mathrm{E}$ of the crest of the gravity feature.

Seismic survey: a. Reflection. A NW-SE trending, complex, anticlinal structure suggested by a reflection horizon near the top of the Zechstein. The well is located about $2 \mathrm{~km}$. W of the crest of the structure, where the top of the Zechstein is suggested at a depth of about 6030' (ca. $1838 \mathrm{~m}$.) by the reflection survey.

b. Refraction. A high speed refraction marker indicates a small, local structure. The refraction marker assumed to be Dolomite or pre-Zechstein basement.

The well is located on the crest of the feature, where the refraction marker is suggested at a depth of about 6530' (ca. $1990 \mathrm{~m}$.).

Previous core drill results: None.

Objective: Stratigraphic test to be carried through to the Pre-Zechstein with a full evaluation of the Zechstein.

Location: About $17 \mathrm{~km}$. SE of Ribe City and $3.2 \mathrm{~km}$. S to W of Arnum cross road. Coordinates: $55^{\circ} 13.22^{\prime} \mathrm{N} ; 3^{\circ} 36.87^{\prime} \mathrm{W}$ of Copenhagen Observatory. 
Drilling: Spudded August 6, 1952; completed November 27, 1952.

Elevation: Ground 39.3 m. (129'). Rotary table 42.7 m. (140').

Stratigraphy, main lithology and paleontology:

0 - 39 m. Pleistocene. Sand and sandy clay. (Sand og sandet ler).

$\left(0^{\prime}-129^{\prime}\right)$

39 - 263 m. Miocene. Mica clay, blackish, basal parts brown. (Glimmerler, $\left(129^{\prime}-862^{\prime}\right)$ sort, nederst brunt). Cancris auriculus, Bulimina elongata.

263 - 359 m. Eocene. Clay, greenish grey, sticky, brown in basal parts.

$\left(862^{\prime}-1179^{\prime}\right) \quad$ (Plastisk ler, grønliggråt, nederst brunt). Vaginulinopsis decorata, Cibicides sulzensis, Spiroplectammina carinata, Gaudryina hiltermanni.

359 - 398 m. Lower Eocene and Paleocene. Clay, dark grey with bands of $\left(1179^{\prime}-1305^{\prime}\right) \quad$ silicified claystone. (Ler, mørkegråt med bånd af kiselholdig lerskifer). Pseudovalvulineria sp.

398 - 406 m. Danian. Bryozoan limestone with chert. (Bryozokalk med flint). $(1305$ '-1333') "Discorbis" binkhorsti.

406 - 884 m. Senonian-Turonian. Chalk, white, soft, with chert. Limestone, $\left(1333^{\prime}-2901^{\prime}\right) \quad$ white, in lower parts with marl, greenish grey. (Skrivekridt med flint og hvid kalksten, nedre del med grønliggrå mergel). Pseudotextularia elegans, Angulogavelinella bettenstaedti, Reussella pseudospinulosa, Pseudovalvulineria cf. lorneiana, Stensioeina exsculpta.

884 - 906 m. Cenomanian. Chalk, white with marl, greenish grey. (Kalksten, (2901'-2974') hvid med grønliggrå mergel). Gavelinopsis cenomanica.

906 - 917 m. Lower Cretaceous, Albian. Claystone, reddish brown. (Lersten, (2974'-3007') rødligbrun). Arenobulimina sp.

917 - 992 m. Lower Cretaceous. Claystone, dark greenish grey; lower part: (3007'-3255') silt, greenish grey. (Lersten, mørk grønliggrå; nedre del finsand, grønliggråt). Planularia crepidularis.

$992-1142$ m. Keuper. Claystone, varicoloured, reddish brown, with green $\left(3255^{\prime}-3747^{\prime}\right)$ parts, interbedded with sandstone, reddish brown, with anhydrite. (Lersten, broget, rødligbrun med grønne partier, afvekslende med sandsten, rødligbrun med anhydrit).

$1142-1296 \mathrm{~m}$. Muschelkalk. Claystone, greenish grey and grey, calcareous, $\left(3747^{\prime}-4252^{\prime}\right)$ interbedded and interlaminated with argillaceous limestone and dolomite, grey. (Lersten, grønliggrå og grå, kalkholdig, afvekslende med lag og striber af leret kalksten og dolomit, grå).

$1296-1747$ m. Bunter.

$\left(4252^{\prime}-5732^{\prime}\right)$

1296-1384 m. Röt. Claystone, silty, reddish brown with green portions, $\left(4252^{\prime}-4542^{\prime}\right)$ the lower part varicoloured, with anhydrite throughout. 
(Lersten, finsandet, rødligbrun med grønne partier, nederste del broget. Hele afsnittet med anhydrit).

$1384-1416$ m. Röt. Claystone, greenish grey to grey and reddish brown, $\left(4542^{\prime}-4647^{\prime}\right)$ interbedded with anhydrite, light grey, finely crystalline with rock salt. (Lersten, grønliggrå til grå og rødligbrun afvekslende med lysegrå anhydrit, finkrystallinsk med stensalt).

$1416-1429$ m. Röt. Claystone, greyish brown to varicoloured, reddish $\left(4647^{\prime}-4689^{\prime}\right)$ brown. (Lersten, gråligbrun, broget til rødligbrun). Chara oogoniae.

$1429-1465 \mathrm{~m}$. Sandstone, finegrained with thin beds of claystone, reddish $\left(4689^{\prime}-4807^{\prime}\right)$ brown, micaceous, with anhydrite. (Sandsten, finkornet med tynde lag af lersten, rødligbrun, glimmerholdig med anhydrit).

$1465-1467 \mathrm{~m}$. Siltstone, highly dolomitic and anhydritic, greyish green, $\left(4807^{\prime}-4812^{\prime}\right)$ much black material (organic?). (Finsandsten, meget dolomitisk og anhydritisk, gråliggrøn med stort indhold af sort (organisk?) materiale).

$1467-1747 \mathrm{~m}$. Claystone, silty, reddish brown, with frequent thin bands $\left(4812^{\prime}-5732^{\prime}\right)$ of siltstone, greenish grey, micaceous. (Lersten, finsandet, rødligbrun, med talrige tynde lag af finsandsten, grønliggrå, glimmerholdig).

$1747-1814$ m. Upper Permian, Zechstein.

$\left(5732^{\prime}-5952^{\prime}\right)$

$1747-1762 \mathrm{~m}$. C4(?)-Anhydrite, grey to reddish brown, with conglomer-

$\left(5732^{\prime}-5780^{\prime}\right)$ atic sandstone at the base. (Anhydrit, grå til rødligbrun med konglomeratisk sandsten nederst).

$1762-1800 \mathrm{~m}$. C3( ?)-Dolomite, light brownish grey to light grey, oolitic.

$\left(5780^{\prime}-5907^{\prime}\right) \quad$ (Dolomit, lys brunliggrå til lysegrå, oolitisk).

1800 -1814 m. D4(?)-Anhydrite, white, with inclusions of dolomite. (An-

$\left(5907^{\prime}-5952^{\prime}\right) \quad$ hydrit, hvid med indeslutninger af dolomit).

$1814-1844$ m. Pre-Zechstein. Fanglomeratic rock with angular fragments of $\left(5952^{\prime}-6049^{\prime}\right)$ gneiss including biotite-hornblende gneiss, garnet-hornblende gneiss etc. (NOE-NyGAARD 1963). (Fanglomeratagtig bjergart med skarpkantede gnejspartier bl.a. biotit-hornblende gnejs, granat-hornblende gnejs m.v.)

Well geologists: J.F.F.; M.H.; L.B.R.; N.V.J.; L.J.A.; S.B.J.; K.H.

Micropaleontologist: A.N.

Paleontologists: T.S.; P.H.B.

Lithology: T.S.

Schlumberger interpreter: J.A.N. 
Börglum No. 1 - D.G.U. File No. 9.58.

Gravity anomaly: Structure not related to any apparent gravity anomaly.

Seismic survey: a. Reflection. Apparently closed fold with moderate relief paralleling the Vraa fault on the south or upthrown side. Apparent closure on the order of 200' (about $60 \mathrm{~m}$.). The indicated structure is roughly $10 \mathrm{~km}$. long and $6 \mathrm{~km}$. wide.

b. Refraction. About 500' (ca. $152 \mathrm{~m}$.) of questionable reversal shown on $3600 \mathrm{~m}$./s. horizon at southern end of profile "NJ-5". The horizon lies at about $4100^{\prime}$ (ca. $1250 \mathrm{~m}$.) at the highest point. Control on the deeper $5600 \mathrm{~m} . / \mathrm{s}$. horizon is lost at 13000' (ca. $3962 \mathrm{~m}$.) several km. E of Börglum.

Previous core drill results: Uplift confirmed by core drilling. Closure appears to be on the order of 300' (ca. $90 \mathrm{~m}$.) over an area of about $14 \mathrm{~km}$. in length and $8 \mathrm{~km}$. in width. The feature is bounded to the north by the Vraa fault, to the east by a cross fault, and to the south by regional south dip. To the west it extends under the Skagerrak. Potential fault $\mathrm{S}$ of the well location.

Objective: A test of the Lower Cretaceous-Jurassic-Rhaetic sequence of the seismograph feature south of and on the upthrown side of the Vraa fault.

The reflection seismograph survey suggested the top of the Lower Cretaceous at about 1600' (ca. $490 \mathrm{~m}$.) below sea level as confirmed by the core drilling program.

Location: About $12 \mathrm{~km}$. SW of Hjörring City and $700 \mathrm{~m}$. NNE of Börglum windmill. Coordinates: $57^{\circ} 22.54^{\prime} \mathrm{N} ; 2^{\circ} 44.28^{\prime} \mathrm{W}$ of Copenhagen Observatory.

Drilling: Spudded August 14, 1951; completed September 26, 1951.

Elevation: Ground 19.2 m. (63'). Rotary table 22.6 m. (74').

\section{Stratigraphy, main lithology and paleontology.}

$0-115 \mathrm{~m}$. Pleistocene. Sand, gravel and clay. (Sand, grus og ler).

$\left(0^{\prime}-378^{\prime}\right)$

115 - 469 m. Senonian. Chalk, white, soft, with chert, bands of greenish $\left(378^{\prime}-1539^{\prime}\right)$ marl in increasing amounts towards basal part. At base, ca. $15 \mathrm{~m}$. of limestone, light grey. (Skrivekridt med flint og hvid kalksten, nedre del hård med mergel). Bolivina incrassata.

$469-485 \mathrm{~m}$. ?Turonian. Claystone, shaly, dark brownish black. (Lersten, $\left(1539^{\prime}-1591^{\prime}\right)$ mørk brunsort). Globigerinae.

485 - $507 \mathrm{~m}$. Cenomanian. Clay and claystone, light greenish grey. (Ler og $\left(1591^{\prime}-1662^{\prime}\right)$ lersten, lys grønliggrå). Gavelinopsis cenomanica.

$507-804 \mathrm{~m}$. Lower Cretaceous. Claystone, greenish to greyish black, sandy. $\left(1662^{\prime}-2639^{\prime}\right)$ At base: sand, argillaceous. (Lersten, grønlig sort til grålig sort, sandet; nederst: sand, leret). Fish remains, Gavelinella $s p$., Planularia crepidularis, Megaspores. 
$804-1009$ m. Upper Jurassic.

$\left(2639^{\prime}-3311^{\prime}\right)$

$804-881 \mathrm{~m}$. Lower Portlandian. Sand and sandstone, in top part inter$\left(2639^{\prime}-2889^{\prime}\right)$ laminated with claystone, in lower part alternating with claystone. (Sand og sandsten i øverste del vekslende med tynde lerstenslag, forneden vekslende med lersten). Astarte saemanni, Buchia fischeri, Protocardia morinica.

881 - 911 m. Kimeridgian. Sand, greenish grey, rich in glauconite. (Sand, $\left(2889^{\prime}-2989^{\prime}\right)$ grønliggråt, glaukonitrigt).

$911-1009$ m. Oxfordian. Claystone and shale, dark greenish grey. (Ler$\left(2989^{\prime}-3311^{\prime}\right)$ sten, mørk grønliggrå). Astarte subdepressa, Ostrea delta, Camptonectes lens, Oxytoma expansa, Cucculaea contracta, Quenstedtia cf. gibbosa.

1009 -1182 m. Middle Jurassic, Dogger. Sandstone, with laminae of claystone, $\left(3311^{\prime}-3879^{\prime}\right)$ grey. (Sandsten med tynde lag af lersten, grå). Plant remains. $1182-1368$ m. Lower Jurassic, Lias. Claystone, dark grey to greyish black, $\left(3879^{\prime}-4489^{\prime}\right)$ shaly, interlaminated with sand. Concretionary clay ironstone. (Lersten, mørkegrå til gråsort, med tynde sandlag. Lerjernstenskonkretioner). Haplophragmoides sp., Geinitzina tenera pupoides, Dentalina matutina matutina, Marginulina prima rugosa, Ostracods.

$1368-1524 \mathrm{~m}$. Rhaetic. Sandstone, shale and claystone, interchanging, dark $\left(4489^{\prime}-4999^{\prime}\right)$ grey, greyish black; near base: sandstone with interlaminated claystone. (Sandsten og lersten, afvekslende, mørkegrå, grålig sort, nederst med tynde lerstenslag). Plant remains.

Well geologists: J.F.F.; K.J.L.; G.L.; J.B.S.

Micropaleontologist: A.N.

Paleontologists: T.S.; P.H.B.

Schlumberger interpreter: J.A.N.

Fjerritslev No. 1 - D.G.U. File No. 24.216.

Gravity anomaly: The boring is located about $5 \mathrm{~km}$. SW of the centre of residual gravity maximum "37" and near the northeastern flank of residual gravity minimum "V", Fjerritslev.

Seismic survey: Reflection. A closed structure of anticlinal type. Possibility of complex faulting along the NE-SW trending crest and in transverse directions. The reflection horizon near the base of the Upper Cretaceous indicates possibility of two minor closed areas along the crest. The well is placed near the southwestern centre on the suggested downthrown side of the NE-SW trending fault. Indicated minimum closure near the base of the Upper Cretaceous about $400 \mathrm{~m}$. Closed area approximately $50 \mathrm{~km}^{2}$. 
Previous core drill results: Fjerritslev Core Hole No. 1: no conclusive results. Objective: Test of the Jurassic-Rhaetic interval for oil and gas accumulations, and test of the Jurassic (Malm, Dogger, and Lias) for source bed studies.

Location: $3.1 \mathrm{~km}$. WSW of Fjerritslev railway station. Coordinates: $57^{\circ} 04$. $872^{\prime} \mathrm{N} ; 3^{\circ} 21.725^{\prime} \mathrm{W}$ of Copenhagen Observatory.

Drilling: Spudded February 14, 1958; completed February 28, 1958.

Elevation: Ground $4.5 \mathrm{~m}$. Rotary table $8.0 \mathrm{~m}$.

Stratigraphy, main lithology and paleontology:

0 - 2 m. Pleistocene. Sand.

2 - 274 m. Senonian-?Turonian. Chalk, white, soft, with chert. Limestone, white, with traces of greenish marl. (Skrivekridt med flint og kalksten med spor af grønlighvid mergel). Stensioeina pommerana, Reussella pseudospinulosa.

274 - 287 m. Cenomanian. Limestone, white, with greenish marl. (Hvid kalksten med grønlig mergel). Gavelinopsis cenomanica.

287 - 404 m. Lower Cretaceous, Albian-Valanginian. Claystone, dark grey, greenish grey. (Lersten, mørkegrå og grønliggrå). Glomospira sp., Planulina sp., Epistomina spinulifera, Epistomina caracolla.

404 - 452 m. Upper Jurassic, Malm. Claystone and silt, greenish grey. (Lersten og finsand, grønliggråt). Lenticulina sp., Astacolus sp., Haplophragmoides $s p$.

452 - 647 m. Middle Jurassic, Dogger. Claystone, shale, and siltstone, brownish grey. (Lersten og finsand, brunliggråt). Marginulinopsis sp., Reinholdella of. dreheri, Lenticulina d'orbignyi.

647 - 915 m. Lower Jurassic, Lias. Claystone, shale, and siltstone, dark grey. (Lersten og finsand, mørkegråt). Saracenaria sublaevis, Bolivina liasica.

Well geologists: A.F.B.; A.D.

Micropaleontologist: A.B.

Schlumberger interpreters: A.F.B.; J.M.D.; T.S.

Fjerritslev No. 2 - D.G.U. File No. 24.217.

Gravity anomaly: About $2 \mathrm{~km}$. W of the centre of residual gravity maximum “37", and $7 \mathrm{~km}$. NE of the centre of residual gravity minimum "V", Fjerritslev.

Seismic survey: Reflection. Structure description, see Fjerritslev No. 1. Well No. 2 is placed in the northeastern minor closed area on the crest, close W of the centre, on the upthrown side of a suggested minor fault with E-W trend.

Previous core drill results: None.

Objective: Stratigraphic test of the flank of the large, faulted structure 
suggested by the reflection seismograph survey, and check of the possible flank convergence for oil and gas accumulation in the Jurassic-Rhaetic strata.

Location: $1.4 \mathrm{~km}$. NW of Fjerritslev railway station and $2.9 \mathrm{~km}$. NE of Fjerritslev No. 1. Coordinates: $57^{\circ} 05.768^{\prime} \mathrm{N}$; $3^{\circ} 19.590^{\prime} \mathrm{W}$ of Copenhagen Observatory.

Drilling: Spudded March 12, 1958; completed May 5, 1958.

Elevation: Ground $4.5 \mathrm{~m}$. Rotary table $8.0 \mathrm{~m}$.

Stratigraphy, main lithology and paleontology:

0 - $12 \mathrm{~m}$. Pleistocene. Sand and gravel. (Sand og grus).

12 - $274 \mathrm{~m}$. Senonian. Chalk, white, soft, with chert. Limestone, white and whitish grey, with marl, pale green. (Skrivekridt med flint og hvid til hvidliggrå kalksten med lys grønlig mergel). Bolivina incrassata, Bolivinoides draco draco, Stensioeina pommerana, Angulogavelinella bettenstaedti, Reussella pseudospinulosa.

274 - 286 m. Santonian-Turonian. Limestone, white, some cuttings slightly glauconitic. (Hvid kalksten stedvis svagt glaukonitholdig). Globotruncana spp., Arenobulimina spp.

286 - 299 m. Cenomanian. Marl, greenish, glauconitic. (Mergel, grønlig, glaukonitisk). Hagenowella advena, Gavelinopsis cenomanica.

$299-1074$ m. Lower Cretaceous, Albian-Valanginian. Claystone and clay, greenish grey, blackish grey, locally siltstone, green, micaceous, and sandstone, green, rich in glauconite. (Lersten og ler, grønliggrå og sortegrå, enkelte lag af finsandsten, grøn, glimmerholdig og sandsten, grøn, glaukonitrig). Epistomina intercedens, Epistomina caracolla, Planularia crepidularis.

1074 -1177 m. Upper Jurassic, Malm. Claystone and clay, dark greenish grey, shale, dark grey, very silty. (Lersten og ler, mørkt grønliggråt og mørkegråt, meget finsandet). Saracenaria sp., Lenticulina sp., Haplophragmoides sp., Macrodentina (Polydentina) aff. wicherii (Klingler det.)

1177 -1539 m. Middle Jurassic, Dogger. Shale, dark grey, with sandstone, whitish green, glauconitic, finegrained. (Lersten, mørkegrå med hvidliggrøn sandsten, glaukonitisk, finkornet). Ammodiscus sp., Ostracods, Reophax multilocularis, Reinholdella cf. dreheri, Fish teeth, Pyrite casts of gastropods.

$1539-2300 \mathrm{~m}$. Lower Jurassic, Lias. Shale, grey and dark grey to greenish grey, beds of siderite, in lower part: beds of sandstone, white. (Lersten, grå og mørkegrå, med lag af siderit, forneden lag af hvid sandsten). Dentalina matutina, Bolivina liasica, Marginulina prima, Planularia stilla.

$2300-2326 \mathrm{~m}$. Rhaetic. Alternating thin beds of shale, dark grey, silty, 
micaceous, and sandstone, white, slightly glauconitic with coal fragments. (Afvekslende tynde lag af lersten, mørkegrå, finsandet, glimmerholdig og sandsten, hvid, svagt glaukonitholdig med brudstykker af kul).

2326 -2341 m. Keuper. Shale, variegated, reddish brown and yellowish green. (Lersten, broget, rødligbrun og gulliggrøn).

Well geologists: A.F.B.; A.D.

Micropaleontologist: A.B.

Schlumberger interpreters: A.F.B.; J.M.D.; T.S.

Flyvbjerg No. 1 - D.G.U. File No. 9.317.

Gravity anomaly: SW flank of residual gravity maximum " 38 " with a relief of $6 \mathrm{mgal}$, about $8 \mathrm{~km}$. S of the centre of the anomaly.

Seismic survey: Reflection. The reflection horizon near the base of the Upper Cretaceous suggests a long NW-SE trending structure of anticlinal type, apparently flanked to the NE and WSW by faults. A graben with trend parallel to the structure close NE to its flank might be related to the suggested faulting. The well is located close to the top of the structure.

Previous core drill results: See Börglum No. 1. Flyvbjerg No. 1 is placed structurally higher than Börglum No. 1, probably the two wells test the same feature.

Objective: Test of the Lower Cretaceous-Jurassic-Rhaetic sequence for oil and gas accumulation.

Location: $7.5 \mathrm{~km}$. ENE of Brönderslev City and $3.2 \mathrm{~km}$. NW of Jerslev village. Coordinates: $57^{\circ} 18.260^{\prime} \mathrm{N} ; 2^{\circ} 31.365^{\prime} \mathrm{W}$ of Copenhagen Observatory.

Drilling: Spudded June 14, 1958; completed July 5, 1958.

Elevation: Ground $44.1 \mathrm{~m}$. Rotary table $47.4 \mathrm{~m}$.

Stratigraphy, main lithology and paleontology:

0 - 145 m. Pleistocene. Sand, gravel, marine clay, and glacial drift. (Sand, grus, marint ler og istidsdannelser).

145 - 492 m. Senonian. Chalk, white, soft, with chert in upper parts, downwards with greyish green marl; basal $10 \mathrm{~m}$.: limestone, white, glauconitic. (Skrivekridt foroven med flint, nedefter med grålig grøn mergel og nederst kalksten, hvid, glaukonitholdig). Buliminella laevis, Marssonella oxycona, Stensioeina pommerana, Bolivina incrassata, Globorotalites michelinianus.

492 - $520 \mathrm{~m}$. Turonian-Cenomanian. Marl, green, with limestone, white, glauconitic. (Mergel, grøn med hvid, glaukonitholdig kalksten). Globigerina spp., Cibicides formosus. 
520 - 777 m. Lower Cretaceous. Claystone and clay, dark greyish black. Basal $30 \mathrm{~m}$.: sand, white, loose, fine to medium grained. (Lersten og ler, gråsort; forneden: sand, hvidt, fint til mellemkornet). Gavelinella sp., Epistomina spinulifera, Epistomina caracolla.

777 - 951 m. Upper Jurassic, Malm. Sand, white, fine grained, glauconitic, micaceous, locally with claystone or clay, greyish green, silty. (Sand, hvidt, finkornet, glaukonit- og glimmerholdigt, stedvis med lersten eller ler, grågrønt, finsandet). Saracenaria $s p$., Macrodentina (Polydentina) wicherii (Klingler det.).

951 -1094 m. Middle Jurassic, Dogger. Claystone, greenish grey, light grey, silty; with beds of shale, greenish grey; sand, greenish white, glauconitic; and sandstone, glauconitic. (Lersten, grønliggrå, lysegrå, finsandet; med lag af lersten, grønliggrå; sand, grønlighvidt, glaukonitisk; og sandsten, glaukonitisk).

1094-1149 m. Lower Jurassic, Lias. Shale, green to greenish grey; with claystone, greenish grey, silty. (Lersten, grøn til grønliggrå, stedvis finsandet). Haplophragmoides sp., Ammobaculites sp., Ostracods, Megaspores.

$1149-1306 \mathrm{~m}$. Lias. Shale and Claystone, light greenish grey, sand, greyish white. (Lersten, lys grønliggrå og sand, grålighvidt). Reophax multilocularis, Bolivina liasica, Marginulina prima.

$1306-1486$ m. Rhaetic. Sand, greenish white; sandstone, brownish white, and shale, dark grey. (Sand, grønlighvidt; sandsten, brunlighvid og lersten, mørkegrå). Plant remains: leaves, spores. Ostracods.

$1486-1695$ m. Keuper. Shale, variegated, green, reddish brown, and sandstone, coarse, whitish grey. (Lersten, broget, grøn og rødligbrun, og sandsten, grovkornet, hvidliggrå).

Well geologists: A.F.B.; J.M.D.; L.J.A.

Micropaleontologist: A.B.

Schlumberger interpreters: A.F.B.; J.M.D.; T.S.

\section{Frederikshavn No. 1 - D.G.U. File No. 11.172.}

Gravity anomaly: NW flank of unnumbered residual gravity maximum.

Seismic survey: a. Reflection. The survey was of such poor quality that interpretation was extremely difficult. A high area W of Frederikshavn was indicated.

b. Refraction. $6000 \mathrm{~m}$./s. horizon at an estimated depth of $4600^{\prime}$ (ca. $1402 \mathrm{~m}$.) beneath the drilling location. Local structure on this horizon not known to exist, but closure on the order of $200^{\prime}$ (ca. $61 \mathrm{~m}$.) indicated some 7-8 km. to the SW. 
Previous core drill results: Indications of a high area, but no conclusive results.

Objective: A test of the Lower Cretaceous-Jurassic-Rhaetic sequence, the nature of the $6000 \mathrm{~m}$./s. material, and the source of the shallow natural gas in the area.

Location: Southern part of Frederikshavn City and $120 \mathrm{~m}$. W of Koktvedgaard farm. Coordinates: $57^{\circ} 26.02^{\prime} \mathrm{N} ; 2^{\circ} 03.40^{\prime} \mathrm{W}$ of Copenhagen Observatory.

Drilling: Spudded July 3, 1950; completed August 22, 1950.

Elevation: Ground 9.5 m. ( $\left(31^{\prime}\right)$. Rotary table 12.8 m. (42').

Stratigraphy, main lithology and paleontology:

0 - 204 m: Pleistocene. Glacial drift and marine interglacial clay. (Istids-

$\left(0^{\prime}-669^{\prime}\right)$ dannelser og marint, interglacialt ler).

204 - 333 m. Santonian. Chalk, white, soft, with laminae of greenish marl.

$\left(669^{\prime}-1094^{\prime}\right)$ Basal 18 m.: limestone with seams of greenish marl. (Kridt, blødt med tynde lag af grønlig mergel. Nederst hårdere kalksten med bånd af grønlig mergel). Stensioeina exsculpta.

$333-352 \mathrm{~m}$. Turonian. Shale, grey to greyish black, often silty, calcareous. $\left(1094^{\prime}-1154^{\prime}\right) \quad$ (Lersten, grå til gråligsort, ofte finsandet, kalkholdig). Globigerinae, Globotruncana spp.

$352-358 \mathrm{~m}$. Cenomanian. Silt, argillaceous, light greenish grey, with $\left(1154^{\prime}-1174^{\prime}\right)$ glauconite. (Finsand, leret, lyst grønliggråt med glaukonit). Gavelinopsis cenomanica, Cibicides formosus.

358 - 579 m. Lower Cretaceous. Sand and silty clay, light grey to greenish $\left(1174^{\prime}-1898^{\prime}\right)$ grey. (Sand og finsandet ler, lysegråt til grønliggråt). Arenaceous foraminifera, Planularia crepidularis.

$579-646$ m. Upper Jurassic, Malm. Silt and silty clay, greenish grey. $\left(1898^{\prime}-2119^{\prime}\right)$ (Finsand og finsandet ler, grønliggråt). Megaspores, Plant remains.

646 - 756 m. Middle Jurassic, Dogger. Sand, silty, clay and claystone, silty, $\left(2119^{\prime}-2479^{\prime}\right)$ greenish grey to greyish black. (Sand, finsandet; ler og lersten, finsandet, grønliggrå til gråsort). Arenaceous foraminifera, Plant remains.

$756-810 \mathrm{~m}$. Lower Jurassic, Lias. Claystone and shaly claystone, light $\left(2479^{\prime}-2657^{\prime}\right)$ green to greenish grey, often silty, some siderite. (Lersten, lys grøn til grønliggrå, ofte finsandet, med siderit).

810 - 903 m. Lower Jurassic, Lias. Claystone, often silty, greenish grey; $\left(2657^{\prime}-2962^{\prime}\right)$ sand, fine, brownish grey, greenish grey; claystone, greyish black, silty. (Lersten, ofte finsandet, grønliggrå; sand, fint, brunliggråt og grønliggråt; og lersten, gråsort, finsandet). Reophax sp., Ammobaculites fontinensis, Trochammina sp., Marginulina prima rugosa, Bolivina liasica. 
903 - 980 m. Rhaetic. Sand, whitish grey, with laminae of clay, greyish $\left(2962^{\prime}-3216^{\prime}\right)$ black. (Sand, hvidliggråt med tynde lag af ler, gråligsort). Plant remains.

980-1014 m. Keuper. Claystone, brownish grey, greenish grey, with lenses (3216'-3326') of sand. (Lersten, brunliggrå og grønliggrå med linser af sand).

$1014-1286 \mathrm{~m}$. ?Triassic. Arkose and argillaceous arkose. (Arkose og leret $\left(3326^{\prime}-4219^{\prime}\right)$ arkose).

$1286-1314$ m. Pre-Cambrian. Gneiss, light, greenish-grey, phyllitic, of granitic $\left(4219^{\prime}-4310^{\prime}\right)$ composition, with high potassium content. Low degree of metamorphism (NoE-NYGAARD 1963). Gnejs, lys, grønliggrå, fyllitisk, med granitisk sammensætning. Lav"metamorfosegrad).

Well geologists: K.J.L.; E.C.; P.H.B.; G.L.

Micropaleontologist: A.N.

Paleontologist: T.S.

Schlumberger interpreters: J.A.N.; T.S.

\section{Frederikshavn No. 2 - D.G.U. File No. 11.194.}

Gravity anomaly, seismic survey and previous core drill results: see Frederikshavn No. 1. (D.G.U. File No. 11.172).

Objective: Part of a program (including Frederikshavn No. 1, 2, and 3) to test the structural situation and the potential pre-Upper Cretaceous origin of the natural gas in the area.

Location: SW of Frederikshavn City and about $700 \mathrm{~m}$. SW of deep test Frederikshavn No. 1 . Coordinates: $57^{\circ} 25.76^{\prime} \mathrm{N} ; 2^{\circ} 03.92^{\prime} \mathrm{W}$ of Copenhagen Observatory.

Drilling: Spudded April 21, 1952; completed May 28, 1952.

Elevation: Ground 12.2 m. (40'). Rotary table 15.5 m. (51').

Stratigraphy, main lithology and paleontology:

0 - $208 \mathrm{~m}$. Pleistocene. Clay, sticky and silty; glacial drift and marine

$\left(0^{\prime}-682^{\prime}\right)$ interglacial beds. (Ler, fedt og finsandet; istidsdannelser og lag af marint interglacial).

$208-308 \mathrm{~m}$. Senonian. Chalk, white, soft, increasing content of greenish $\left(682^{\prime}-1009^{\prime}\right)$ grey marl with depth; near base: limestone, white, hard. (Skrivekridt, nedefter med tiltagende indhold af grønliggrå mergel; nedre del: kalksten, hvid, hård). Globorotalites michelinianus, Pseudovalvulineria cf. lorneiana, Stensioeina exsculpta, Globotruncana spp.

$308-325$ m. Turonian. Shale, greyish black to greenish grey. (Lersten, grå$\left(1009^{\prime}-1065^{\prime}\right)$ sort til grønliggrå). Globigerina spp., Globotruncana spp. 
325 - 332 m. Cenomanian. Siltstone, light grey, with glauconite. (Finsand$\left(1065^{\prime}-1089^{\prime}\right) \quad$ sten, lysegrå med glaukonit). Gavelinopsis cenomanica.

332 - 548 m. Lower Cretaceous. Sand, interbedded with silty clay and silt. $\left(1089^{\prime}-1798^{\prime}\right) \quad$ (Sand afvekslende med finsandet ler og finsand). Epistominae (ribbed forms).

$548-615$ m. Upper Jurassic, Malm. Sand, fine grained, towards bottom $\left(1798^{\prime}-2019^{\prime}\right)$ silty clay, greenish grey. (Sand, fint, nedefter finsandet ler, grønliggråt).

615 - 728 m. Middle Jurassic, Dogger. Sand, fine grained, grey to brownish $\left(2019^{\prime}-2389^{\prime}\right)$ grey, interbedded with silty clay and claystone, light greenish grey. (Sand, fint, gråt til brunliggråt, vekslende med finsandet ler og lersten, lys grønliggrå).

728 - 880 m. Lower Jurassic, Lias. Shale, brownish grey, with concretionary $\left(2389^{\prime}-2887^{\prime}\right)$ clay ironstone, interlaminated with sand, fine grained, and silt, dark grey. (Lersten, brunliggrå med lerjernstenskonkretioner vekslende med tynde lag af sand, fint, og finsand, mørkegråt). Marginulina prima rugosa, Vaginulina listi, Trochammina sp., Ammodiscus asper, Astacolus varians.

880 - 960 m. Rhaetic. Sand, light grey, with bands of claystone, shaly, dark $\left(2887^{\prime}-3149^{\prime}\right)$ grey. (Sand, lysegråt med bånd af mørkegrå lersten). Megaspores, Plant remains.

$960-1006 \mathrm{~m}$. Keuper. Claystone, varicoloured, with some lenses of sand. $\left(3149^{\prime}-3299^{\prime}\right) \quad$ (Lersten, broget med sandlinser).

$1006-1076 \mathrm{~m}$. ?Triassic. Arkose, and argillaceous arkose, varicoloured. (Ar$\left(3299^{\prime}-3531^{\prime}\right) \quad$ kose og leret arkose, broget).

\author{
Well geologists: J.F.F.; M.H.; L.B.R. \\ Micropaleontologist: A.N. \\ Paleontologist: P.H.B. \\ Schlumberger interpreters: J.A.N.; T.S.
}

Frederikshavn No. 3 - D.G.U. File No. 7.695.

Gravity anomaly, seismic survey and previous core drill results: see Frederikshavn No. 1 (D.G.U. File No. 11.172).

Objective: Part of a program (including Frederikshavn No. 1, 2, and 3) to test the structural situation and the potential pre-Upper Cretaceous origin of the natural gas in the area.

Location: $2 \mathrm{~km}$. $\mathrm{N}$ of Frederikshavn railway station and about $3 \mathrm{~km}$. $\mathrm{N}$ t. E of Frederikshavn No. 1. Coordinates: $57^{\circ} 27.52^{\prime} \mathrm{N} ; 2^{\circ} 02.64^{\prime} \mathrm{W}$ of Copenhagen Observatory.

Drilling: Spudded June 6, 1952; completed July 26, 1952.

Elevation: Ground 7.0 m. (23'). Rotary table 10.4 m. (34'). 
Stratigraphy, main lithology and paleontology:

0 - $287 \mathrm{~m}$. Pleistocene. Glacial drift and marine interglacial clay and silt.

$\left(0^{\prime}-943^{\prime}\right) \quad$ (Istidsdannelser og marint interglacialt ler og finsand).

$287-316 \mathrm{~m}$. Santonian. Chalk and limestone, white, greyish white, with $\left(943^{\prime}-1037^{\prime}\right)$ bands of marl, greenish grey; at base limestone, hard, greyish white. (Skrivekridt og hvid til grålighvid kalksten med bånd af grønliggrå mergel, nederst hård grålighvid kalksten). Stensioeina exsculpta.

316 - 334 m. Turonian. Shale, dark grey to greenish grey. (Lersten, mørkegrå $\left(1037^{\prime}-1096^{\prime}\right)$ til grønliggrå). Globigerinae.

$334-341 \mathrm{~m}$. Cenomanian. Sand and silt, argillaceous, light grey, with $\left(1096^{\prime}-1120^{\prime}\right)$ glauconite. (Sand og silt, leret, lysegråt med glaukonit). Gavelinopsis cenomanica.

341 - 554 m. Lower Cretaceous. Sand, fine grained, dark grey, silty clay. $\left(1120^{\prime}-1819^{\prime}\right) \quad$ (Sand, fint, mørkegråt, finsandet ler). Planularia crepidularis.

554 - 621 m. Upper Jurassic, Malm. Sand, silt and silty clay, greenish grey.

$\left(1819^{\prime}-2039^{\prime}\right) \quad$ (Sand, finsand og finsandet ler, grønliggråt).

621 - 724 m. Middle Jurassic, Dogger. Sand, silty clay, and claystone, inter$\left(2039^{\prime}-2374^{\prime}\right)$ bedded, grey to greenish grey. (Sand, finsandet ler og lersten i afvekslende lag, grå til grønliggrå).

724 - 867 m. Lower Jurassic, Lias. Shale and clay, light greenish grey, with $\left(2374^{\prime}-2844^{\prime}\right)$ concretions of clay ironstone; in lower part: sand, fine grained, argillaceous; at base: claystone, silty, dark grey. (Lersten og ler, lyst grønliggråt med lerjernstenskonkretioner, i nedre del sand, fint, leret og nederst lersten, finsandet, mørkegrå). Marginulina prima prima, Lenticulina acutiangulata, Dentalina matutina matutina, Bolivina liasica.

867 - 931 m. Rhaetic. Sand and clay, silty, interbedded, light grey. (Sand og (2844'-3054') finsandet ler i afvekslende lag, lysegråt). Plant remains.

931 - 978 m. Keuper. Claystone, light greenish grey, changing with reddish $\left(3054^{\prime}-3209^{\prime}\right)$ brown claystone; and sand, coarse with felspar. (Lersten, lys grønliggrå, vekslende med rødligbrun lersten, og sand, groft med feldspat).

$978-1005 \mathrm{~m}$. ?Triassic. Arkosic sandstone. (Arkoseagtig sandsten). $\left(3209^{\prime}-3296^{\prime}\right)$

Well geologists: E.C.; J.F.F.; G.V.O.; K.H.

Micropaleontologist: A.N.

Schlumberger interpreters: J.A.N.; T.S. 


\section{Gassum No. 1 - D.G.U. File No. 58.231.}

Gravity anomaly: Located about $2 \mathrm{~km}$. E of the centre of gravity anomaly "X" at Hvidsten mill, about $1.5 \mathrm{~km}$. S of Gassum, E of the highway. "X" is a residual gravity minimum with a negative relief of 3.8 mgal interpreted as a deepseated salt structure.

Seismic survey: a. Reflection. Not worked when the well was spudded. b. Refraction. Records fair to questionable. A relatively shallow horizon worked out, but interpretation hampered by velocity changes along profile "X-1" from $3550 \mathrm{~m}$./s. on the western end to 3360, 3550, and $3900 \mathrm{~m}$./s. at the eastern end. Closure of $300^{\prime}$ (ca. $90 \mathrm{~m}$.) between 1100' and 1400' (ca. 335-427 m.). The closed area is $12 \mathrm{~km}$. in length and $6.5 \mathrm{~km}$. in width.

Previous core drill results: The structure is evident from the surface geological map of the area as is also emphasized in the Danish geological literature, but closure was not obvious to the NE. Results from three very shallow "Failing" tests at Hem on the northeastern flank of the structure inconclusive.

Objective: A test of the Lower Cretaceous-Jurassic-Rhaetic interval. Attempt to reach the Zechstein dolomite horizon (i.e. "the Hauptdolomite of the middle Zechstein" later known as the "C-3 Dolomite").

Location: About $12 \mathrm{~km}$. $\mathrm{N}$ of Randers City, E of Mariager highway. Coordinates: $56^{\circ} 33.76^{\prime} \mathrm{N} ; 2^{\circ} 34.36^{\prime} \mathrm{W}$ of Copenhagen Observatory.

Drilling: Spudded March 18, 1948; completed March 9, 1951. Drilling operations suspended from February 25, 1949 to December 19, 1950.

Elevation: Ground 53.5 m. (175'). Rotary table 57.9 m. (190').

Stratigraphy, main lithology and paleontology:

0 - 25 m. Pleistocene. Glacial drift. (Istidsdannelser).

$\left(0^{\prime}-82^{\prime}\right)$

25 - $749 \mathrm{~m}$. Maastrichtian and Campanian. Chalk, white, with chert, and

$\left(82^{\prime}-2459^{\prime}\right)$ limestone, white, soft, in lower part harder, with beds of marl, greenish grey. (Skrivekridt med flint og blød, hvid kalksten, forneden hårdere og med lag af mergel, grønliggrå). Bolivina incrassata, Globorotalites michelinianus.

749 - 997 m. Santonian, ?Turonian, and Cenomanian. $\left(2459^{\prime}-3272^{\prime}\right)$

749 - 793 m. Santonian. Limestone, light grey, argillaceous, hard, with $\left(2459^{\prime}-2603^{\prime}\right)$ bands and thin beds of shale, dark grey to greenish grey. Near base gradual change into shale, dark grey, hard, with bands of limestone, light grey, hard. (Kalksten, lysegrå, leret, hård med tynde lag af lersten, mørkegrå til grønliggrå, forneden jævn overgang til hård lersten med bånd af lysegrå, hård kalksten). Stensioeina exsculpta. 
793 - 997 m. Santonian, ?Turonian, and Cenomanian. Limestone, green$\left(2603^{\prime}-3272^{\prime}\right) \quad$ ish grey to light grey, very hard, with frequent beds of shale, greenish grey. (Kalksten, grønliggrå til lysegrå, meget hård med talrige lag af lersten, grønliggrå). Globotruncana spp.

$997-1085$ m. Lower Cretaceous, Albian-Hauterivian. Shale, dark grey, and $\left(3272^{\prime}-3560^{\prime}\right)$ shale, sandy, grey to dark grey. (Lersten, mørkegrå og sandet lersten, grå til mørkegrå). ? Deshayesites sp., Lyticoceras noricum, Glomospira sp., Epistomina spinulifera, Planularia crepidularis.

$1085-1139$ m. ?Upper Jurassic. (Kimeridgian-Portlandian?) Sand, light grey, $\left(3560^{\prime}-3738^{\prime}\right)$ greenish grey, silty, with bands of sandstone, greenish grey. (Sand, lysegråt og grønliggråt, finsandet med bånd af sandsten, grønliggrå). Plant remains, small pelecypods.

$1139-1198$ m. Upper Jurassic, Oxfordian and basal Kimeridgian. Shale, sandy, $\left(3738^{\prime}-3931^{\prime}\right)$ dark grey to bluish grey, locally thin beds of sandstone, shaly, greenish grey. (Lersten, sandet, mørkegrå til blågrå, enkelte tynde lag af lersandsten, grønliggrå). Paravirgatites cf. paravirgatus, Lima mutabilis, Trigonia hudlestoni, Isognomon promytiloides.

$1198-1306$ m. Lower Jurassic, Lias delta. Shale, dark grey, locally with $\left(3931^{\prime}-4285^{\prime}\right) \quad$ concretionary clay ironstone. (Lersten, mørkegrå med enkelte lerjernstenskonkretioner). Pleuroceras spinatum, Amaltheus margaritatus, Saracenaria sublaevis, Bolivina liasica, Pseudoglandulina vulgata pupoides, Marginulina prima prima, Marginulinopsis breoni.

1306-1361 m. Lias gamma. Shale, dark grey, with shaly sandstone, grey in $\left(4285^{\prime}-4465^{\prime}\right)$ lower part. (Lersten, mørkegrå, forneden med grå lersandsten. Aegoceras capricornu, Polymorphites sp., Geinitzina tenera tenera, Marginulinopsis radiata, Ostracods.

$1361-1407 \mathrm{~m}$. Lias beta. Shale, dark greenish grey, locally concretionary clay $\left(4465^{\prime}-4615^{\prime}\right)$ ironstone. (Lersten, mørk grønliggrå med enkelte lerjernstenskonkretioner). Promicroceras planicosta, Paleoneilo galatea, Vaginulina listi, Dentalina matutina.

$1407-1513$ m. Lias alpha. Shale, dark grey, locally with laminae of sandstone, $\left(4615^{\prime}-4965^{\prime}\right)$ grey, with concretions of clay ironstone. (Lersten, mørkegrå med enkelte tynde lag af grå sandsten og lerjernstenskonkretioner). Schlotheimia angulata, Psiloceras sp., Oxytoma inaequivalvis, Gryphaea of. arcuata, Marginulina radiata, Nodosaria metensis, Marginulinopsis matutina, Planularia stilla.

$1513-1710$ m. Rhaetic. Shale, dark grey, interbedded with sand and sandstone, $\left(4965^{\prime}-5610^{\prime}\right)$ light grey, and oolites. (Lersten, mørkegrå afvekslende med sand og sandsten, lysegrå). Taeniodon ewaldi, Ammobaculites sp., Ammodiscus sp., Fish remains, Ostracods, Plant remains. 
$1710-2166$ m. Keuper. Shale, varicoloured, greenish grey to reddish brown, $\left(5610^{\prime}-7105^{\prime}\right)$ with anhydrite, rock salt and dolomite. (Lersten, broget, grønliggrå til rødligbrun med anhydrit, stensalt og dolomit).

$2166-3453 \mathrm{~m}$. Bunter. Shale, claystone and sandstone, reddish brown. (Ler$\left(7105^{\prime}-11331^{\prime}\right)$ sten og sandsten, rødligbrun).

$3453-3458 \mathrm{~m}$. ?Permian, Zechstein. Sandstone and silty clay, with anhydrite $\left(11331^{\prime}-11344^{\prime}\right)$ and rock salt. (Sandsten og finsandet ler med anhydrit og stensalt).

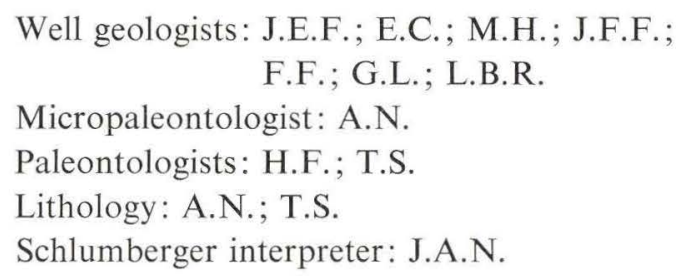

Glamsbjerg No. 1 - D.G.U. File No. 145.154.

Gravity anomaly: Residual gravity maximum " 56 " with a relief of 4.5 mgal. The feature suggests a basement uplift bordered by a northwest-southeast trending fault to the south. The location is on the southern edge of the crestal part of the anomaly.

Seismic survey: a. Reflection. Results were poor. Reflection horizon "D" which at Ringe corresponds with the top of the arkose at 4,200' (ca. $1280 \mathrm{~m}$.) could not be identified at Glamsbjerg. This suggested the arkose to be absent, and the basement to be found immediately beneath the Triassic.

b. Refraction. A high velocity rock $(5,400 \mathrm{~m}$./s.) coincident with the gravity anomaly suggested by the refraction survey.

Previous core drill results: None.

Objective: Stratigraphic test to check the character of the high velocity rock and to be carried down to the basement.

Location: About $20 \mathrm{~km}$. SW of Odense Central Station and $2.3 \mathrm{~km}$. NE of Glamsbjerg railway station. Coordinates: $55^{\circ} 17.55^{\prime} \mathrm{N} ; 2^{\circ} 26.88^{\prime} \mathrm{W}$ of Copenhagen Observatory.

Drilling: Spudded July 5, 1951; completed August 2, 1951.

Elevation: Ground 68.0 m. (223'). Rotary table 71.3 m. (234').

Stratigraphy, main lithology and paleontology:

0 - 126 m. Pleistocene. Glacial drift. (Istidsdannelser).

$\left(0^{\prime}-414^{\prime}\right)$

126 - 165 m. Paleocene. Clay, dark grey. (Ler, mørkegråt). Pseudovalvulineria $\left(414^{\prime}-540^{\prime}\right) \quad s p$. 
165 - 204 m. Danian. Bryozoan limestone with chert. (Bryozokalk). "Dis$\left(540^{\prime}-669^{\prime}\right)$ corbis" binkhorsti.

$204-814$ m. Senonian. Chalk, white, with chert; and limestone, white, with $\left(669^{\prime}-2669^{\prime}\right)$ greenish grey marl; at base: limestone, hard. (Skrivekridt med flint og hvid kalksten med grønliggrå mergel, nederst hård kalksten). Pseudotextularia elegans.

$814-834 \mathrm{~m}$. Cenomanian. Marl and limestone, light reddish brown to $\left(2669^{\prime}-2737^{\prime}\right)$ greyish white. (Mergel og kalksten, lys rødligbrun til grålighvid). Gavelinopsis cenomanica.

$834-857 \mathrm{~m}$. Lower Cretaceous. Claystone, clay and shale, reddish brown $\left(2737^{\prime}-2813^{\prime}\right) \quad$ to greyish black. (Lersten og ler, rødligbrun til gråsort).

857 - $901 \mathrm{~m}$. Triassic. Claystone, dark greenish grey and reddish brown $\left(2813^{\prime}-2957^{\prime}\right) \quad$ with green spots. (Lersten, mørk grønliggrå og rødligbrun med grønne pletter).

$901-903$ m. ?Triassic. Arkose, reddish brown with green portions, coarse $\left(2957^{\prime}-2962^{\prime}\right)$ grained with quartz, felspar and dark mica. (Arkose, rødligbrun med grønne partier, grov, med kvarts, feldspat og mørk glimmer).

903 - 909 m. Pre-Cambrian. Hornblende gneiss, dark grey, medium grained, $\left(2962^{\prime}-2981^{\prime}\right)$ granodioritic. Dip abt $45^{\circ}$. Anhydrite on fissures. (NoE-NYGAARD 1963). (Gnejs, mørkegrå, mellemkornet, granodioritisk. Laghældning ca. $45^{\circ}$. Anhydrit i revner i bjergarten).

Well geologists: K.J.L.; J.F.F.; G.L.

Micropaleontologist: A.N.

Schlumberger interpreters: J.A.N.; T.S.

\section{Grindsted No. 1 - D.G.U. File No. 113.123.}

Gravity anomaly: Close to the highest point of residual gravity maximum "11". The anomaly has a minimum relief of $2.5 \mathrm{mgal}$ with a NE - SW trend and the steeper gradient to the SW. It suggests a closed structure.

Seismic survey: Reflection. A complexly faulted local structure on a reflection horizon by drilling proved to be the top of the Precambrian metamorphic gneiss.

Previous core drill results: Eg No. 1-4 confirmed uplift with a relief of 400' (ca. $122 \mathrm{~m}$.) on the top of the Danian. Oligocene deposits probably absent over the structure, present on the flank.

Objective: To test probable fault and structural closure of the Triassic Lower Cretaceous unconformity and to test the Zechstein.

Location: $6.6 \mathrm{~km}$. W t. S of Grindsted railway station and $2 \mathrm{~km}$. ESE of Eg railway station. Coordinates: $55^{\circ} 45.443^{\prime} \mathrm{N} ; 3^{\circ} 45.262^{\prime} \mathrm{W}$ of Copenhagen Observatory.

Drilling: Spudded October 29, 1958; completed November 27, 1958.

Elevation: Ground $31.7 \mathrm{~m}$. Rotary table $34.9 \mathrm{~m}$. 
Stratigraphy, main lithology and paleontology:

0 - 7 m. Pleistocene. Sand.

7 - $187 \mathrm{~m}$. Miocene. Quartz sand and quartz gravel, light grey, and mica clay, brownish black. (Kvartssand og kvartsgrus, lysegråt, og glimmerler, brunligsort). Asterigerina staeschei, Nonion soldanii, Epistomina elegans, Pullenia sphaeroides.

187 - 263 m. Eocene. Marl and clay, greenish grey; lower part: clay, reddish brown. (Mergel og ler, grønliggråt, nedre del rødligbrunt ler). Vaginulinopsis decorata, Cibicides sulzensis, Spiroplectammina carinata.

263 - 289 m. Paleocene. Clay, dark grey, and shale, black. (Ler, mørkegråt og sort lerskifer). Spores, Calcareous spheres, Fish teeth.

289 - 422 m. Danian*. Bryozoan limestone with chert. (Bryozokalk med flint). Osangularia lens.

422 - 937 m. Senonian-?Turonian. Chalk, white, soft, with chert, and in lower part with marl, light grey. (Skrivekridt med flint og i nedre del med lysegrå mergel). Bolivina incrassata, Stensioeina pommerana, Stensioeiana exsculpta.

937 - 941 m. Cenomanian. Chalk, white, glauconitic. (Kalksten, hvid, blød, glaukonitholdig). Gavelinopsis cenomanica.

941 - 948 m. Lower Cretaceous, Albian. Claystone, reddish brown. (Lersten, rødligbrun). Glomospira sp., Planulina sp., Gavelinella sp.

948 - 973 m. Lower Cretaceous, Pre-Albian. Marl, brownish yellow and bluish grey, and shale, greenish grey, glauconitic. (Mergel, brunliggul og blågrå og lersten, grønliggrå, glaukonitisk). Planularia crepidularis.

$973-1208$ m. Keuper. Claystone, variegated, reddish brown, greyish green, and siltstone, greyish green. (Lersten, broget, rødligbrun, grågrøn og finsandsten, grågrøn).

1208 -1308 m. Muschelkalk. Claystone, light grey, calcareous, with limestone, argillaceous, light greyish white. (Lersten, lysegrå, kalkholdig med leret kalksten, lys grålighvid).

$1308-1599$ m. Bunter. Claystone, reddish brown, with anhydrite in top part. Locally sandstone, light reddish brown, fine grained. (Lersten, rødligbrun med anhydrit i øvre del. Enkelte lag af sandsten, rødligbrun, finkornet).

$1599-1647 \mathrm{~m}$. Pre-Cambrian. Biotite gneiss, grey and white, with pink felspar, planar texture (NoE-NygaARD 1963). (Biotitgnejs, grå og hvid med rosa feldspat, stribet tekstur).

Well geologists: A.F.B.; A.D.

Micropaleontologist: A.B.

Schlumberger interpreters: A.F.B.; J.M.D.

* The Danian was originally suggested from 289 to $472 \mathrm{~m}$. and not amended until the cross sections had been printed, this explains disagreements in depth figures. 
Haldager No. 1 - D.G.U. File No. 26.171.

Gravity anomaly: Residual gravity minimum "AH" at Aalborg. Location at the centre of the minimum.

Seismic survey: a. Reflection. Questionable structure coincident with the gravity anomaly suggested and interpreted as a deepseated salt structure of anticlinal type. Laboratory and field interpretations differ appreciably.

The existence of this structure strongly questioned subsequent to drilling of Haldager No. 1. See also Vedsted No. 1, p. 85.

b. Refraction. One profile across the "AH" anomaly ruled out the possibility of shallow salt, but was otherwise of little value.

Previous core drill results: Öster Halne No. 1-6 did not yield any conclusive reliable results as to the structural picture.

Objective: Test of the Cretaceous and the Jurassic.

Location: About $10 \mathrm{~km}$. NW of Nörre Sundby City and $6.5 \mathrm{~km}$. ESE of deep test Vedsted No. 1 (File No. 25.45), E of Haldager village. Coordinates: $57^{\circ} 07.05^{\prime} \mathrm{N} ; 2^{\circ} 47.90^{\prime} \mathrm{W}$ of Copenhagen Observatory.

Drilling: Spudded October 10, 1950; completed December 30, 1950.

Elevation: Ground $1.8 \mathrm{~m} .\left(6^{\prime}\right)$. Rotary table $5.2 \mathrm{~m} .\left(17^{\prime}\right)$.

Stratigraphy, main lithology and paleontology:

0 - $18 \mathrm{~m}$. Pleistocene. Sand, fine grained, and gravel. (Sand, finkornet,

$\left(0^{\prime}-59^{\prime}\right)$ og grus).

18 - 397 m. Senonian. Chalk, white, with chert, and limestone, whitish grey,

$\left(59^{\prime}-1302^{\prime}\right)$ with bands of marl, greenish grey, in basal parts: limestone, light grey. (Skrivekridt med flint og hvidgrå kalksten med bånd af grønliggrå mergel, i nedre del lysegrå kalksten).

397 - 399 m. Turonian. Clay and claystone, light green to greyish black. $\left(1302^{\prime}-1309^{\prime}\right) \quad$ (Ler og lersten, lysegrøn til gråligsort).

399 - 417 m. Cenomanian. Clay and claystone, greenish grey to green. (Ler $\left(1309^{\prime}-1369^{\prime}\right) \quad$ og lersten, grønliggrå til grøn). Gavelinopsis cenomanica.

417 - $825 \mathrm{~m}$. Lower Cretaceous. Claystone, clay and shale, dark grey to $\left(1369^{\prime}-2706^{\prime}\right)$ greyish black. Basal $50 \mathrm{~m}$.: siltstone and sandstone, greenish grey. (Lersten og ler, mørkegråt til gråsort; nederste $50 \mathrm{~m}$ : finsandsten og sandsten, grønliggrå). Saracenaria cf. spinosa, Planularia crepidularis, Lyticoceras noricum.

$825-1078$ m. Upper Jurassic.

$\left(2706^{\prime}-3537^{\prime}\right)$

$825-896$ m. Portlandian. Sandstone, fine grained, greenish grey with

$\left(2706^{\prime}-2950^{\prime}\right)$ laminae of clay, downwards changing into claystone and shale, dark grey to greyish black. (Sandsten, finkornet grønliggrå med tynde lag af ler, nedefter overgang til lersten, mørkegrå til gråsort). Buchia fischeri, Pecten sp., 
Protocardia morinica, Aulacoteuthis magnificus, Parapallasiceras cf. praecox, Reinholdella cf. dreheri, Saracenaria sp., Lenticulina (ribbed forms), Arenaceous foraminifera.

896 - 971 m. Kimeridgian. Siltstone, dark greenish grey, concretionary $\left(2950^{\prime}-3186^{\prime}\right)$ clay ironstone. (Finsandsten, mørk grønliggrå med lerjernstenskonkretioner).

971-1078 m. Oxfordian. Claystone, with shale, dark grey, greenish grey, $\left(3186^{\prime}-3537^{\prime}\right) \quad$ concretionary clay ironstone. (Lersten, mørkegrå og grønliggrå med lerjernstenskonkretioner). Trigonia hudlestoni, Camptonectes lens, Oxytoma expansa, Anisocardia sp., Belemnites sp.

$1078-1403$ m. Middle Jurassic, Dogger. Sandstone, interbedded with thin $\left(3537^{\prime}-4603^{\prime}\right)$ and thick beds of clay or shale, dark grey to light grey. (Sandsten vekslende med tynde og tykke lag af ler eller lersten, mørkegrå til lysegrå). Plant remains.

1403 -1521 m. Lower Jurassic, Lias gamma-Lias delta. Shale, grey to greenish $\left(4603^{\prime}-4989^{\prime}\right)$ grey with single seams and beds of sandstone, silty, argillaceous, greyish brown. (Lerskifer, grå til grønliggrå med enkelte striber og lag af sandsten, finsandet, leret, gråligbrun). Bolivina liasica, Lenticulina gottingensis, Geinitzina tenera praepupa, Dentalina $s p$.

Well geologists: K.J.L.; E.C.; O.B.; P.H.B.; G.L.

Micropaleontologist: A.N.

Paleontology: T.S.

Schlumberger interpreters: J.A.N.; T.S.

Harte No. 1 - D.G.U. File No. 133.108.a.

Geophysical evidence: Located at the southern end of the Vester Nebel magnetic anomaly (maximum).

Objective: Test of the pre-Upper Cretaceous formations.

Location: $4.5 \mathrm{~km}$. WNW of Kolding and $180 \mathrm{~m}$. N of Paaby Nörregaard, $\mathrm{S}$ of Harte village. Coordinates: $55^{\circ} 30.37^{\prime} \mathrm{N} ; 3^{\circ} 09.60^{\prime} \mathrm{W}$ of Copenhagen Observatory.

Drilling: Spudded July 27, 1935; completed July 29, 1936.

Elevation: Ground 29.4 m. $\left(96.5^{\prime}\right)$.

Stratigraphy, main lithology and paleontology:

0 - $72 \mathrm{~m}$. Pleistocene. Sand and boulder clay, glacial drift. (Sand og

$\left(0^{\prime}-236^{\prime}\right)$ moræneler, istidsdannelser).

$72-100 \mathrm{~m}$. Miocene-Oligocene.

$\left(236^{\prime}-327^{\prime}\right)$ 
72 - 99 m. Sand, micaceous, lignite. (Glimmersand, brunkul).

$\left(236^{\prime}-325^{\prime}\right)$

99 - $100 \mathrm{~m}$. Sandstone. (Sandsten).

$\left(325^{\prime}-327^{\prime}\right)$

$100-123$ m. Eocene. Clay, grey, calcareous. (Ler, gråt, kalkholdigt). $\left(327^{\prime}-405^{\prime}\right) \quad$ Terebratulina sp., Cibicides sulzensis, Alabamina sp., Globigerina spp., Globigerinella sp., Spiroplectammina carinata, Vaginulinopsis decorata.

123 - 195 m. Eocene. Clay, grey, light green, sticky, non calcareous. (Ler, $\left(405^{\prime}-640^{\prime}\right)$ gråt, lysegrønt, fedt, kalkfrit).

195 - 204 m. Eocene. Clay, reddish brown, sticky, calcareous. (Ler, rødbrunt, $\left(640^{\prime}-670^{\prime}\right)$ fedt, kalkholdigt).

$204-? 214$ m. Eocene. Clay, grey, with tuff beds. (Gråt ler med vulkanske $\left(670^{\prime}-? 703^{\prime}\right)$ askelag).

?214 - 236 m. Paleocene. Clay, grey. (Gråt ler). Nodosaria torsicostata.

$\left(? 703^{\prime}-775^{\prime}\right)$

236 - 244 m. Paleocene. Clay, grey, with hard siliceous layers. (Gråt ler med $\left(775^{\prime}-799^{\prime}\right)$ hårde, kiselholdige lag).

244 - ?283 m. Danian. Bryozoan limestone, hard, white; with chert. (Bryozo$\left(799^{\prime}-\right.$ ?929') kalk med flint).

?283 - 791 m. Senonian.

$\left(? 929^{\prime}-2595^{\prime}\right)$

?283 - 689 m. Chalk, white, soft with chert. (Skrivekridt og flint). 283-

(?929'-2259') 285 m.: (929'-934') Bolivina incrassata, "Discorbis" binkhorsti, Bolivinoides draco draco, Stensioeina pommerana, Ataxophragmium sp.,(Upper Maastrichtian). 678 m.(2226'): Stensioeina exsculpta gracilis. (Santonian-Coniacian).

$689-697 \mathrm{~m}$. Chert, very hard, white, probably with thin layers of $\left(2259^{\prime}-2287^{\prime}\right) \quad$ chalk, white. (Flint, meget hård, hvid, muligvis med tynde lag af hvid kalksten).

697 - 791 m. Limestone, with marl, grey, and chert (Kalksten med grå $\left(2287^{\prime}-2595^{\prime}\right)$ mergel og flint).

Well geologist: H.Ø.;

Micropaleontologist: A.B.

Paleontology: H.Ø.

Harte No. 2 - D.G.U. File No. 133.108.b.

Geophysical evidence: Same as Harte No. 1, see p. 51.

Objective: Test of the pre-Upper Cretaceous formations.

Location: $4.5 \mathrm{~km}$. WNW of Kolding and $30 \mathrm{~m}$. due W of Harte No. 1. Coordinates: $55^{\circ} 30.37^{\prime} \mathrm{N}$; $3^{\circ} 09.62^{\prime} \mathrm{W}$ of Copenhagen Observatory.

Drilling: Spudded September 2, 1936; completed August 16, 1937.

Elevation: Ground 30.9 m. (101.4') 
Stratigraphy, main lithology and paleontology:

0 - 61 m. Pleistocene. Sand, gravel, clay. (Sand, grus og ler).

$\left(0^{\prime}-200^{\prime}\right)$

61 - 123 m. Miocene, Oligocene, and Eocene. (see Harte No. 1) Clay. (Ler).

$\left(200^{\prime}-402^{\prime}\right)$

123 - 192 m. Eocene. Clay, sticky. (Fedt ler).

$\left(402^{\prime}-630^{\prime}\right)$

$192-210$ m. Eocene. Clay with tuff. (Ler med vulkansk aske).

$\left(630^{\prime}-690^{\prime}\right)$

210 - 232 m. Paleocene. Clay, grey. (Gråt ler).

$\left(690^{\prime}-760^{\prime}\right)$

232 - 240 m. Paleocene. Shale, sandy. (Lersten, sandet).

$\left(760^{\prime}-786^{\prime}\right)$

240 - 276 m. Danian. Bryozoan limestone with chert. (Bryozokalk med flint).

$\left(786^{\prime}-905^{\prime}\right)$

276 - $891 \mathrm{~m}$. Senonian.

$\left(905^{\prime}-2924^{\prime}\right)$

$276-427 \mathrm{~m}$. Chalk, white, soft, with chert. (Skrivekridt med flint).

$\left(905^{\prime}-1400^{\prime}\right)$

427 - $655 \mathrm{~m}$. Chalk, with some chert. (Flintfattigt kridt).

$\left(1400^{\prime}-2150^{\prime}\right)$

$655-678 \mathrm{~m}$. Chalk, hard, no chert. (Kalksten uden flint).

$\left(2150^{\prime}-2226^{\prime}\right)$

$678-688 \mathrm{~m}$. Limestone, very hard with marl. (Kalksten, meget hård $\left(2226^{\prime}-2256^{\prime}\right)$ med mergel).

688 - 789 m. Limestone, with marl, grey, and chert. (Kalksten med grå $\left(2256^{\prime}-2590^{\prime}\right)$ mergel og flint).

789 - $880 \mathrm{~m}$. Chalk, with chert, very hard. (Kalksten med flint, meget $\left(2590^{\prime}-2887^{\prime}\right)$ hård).

880 - 891 m. Chalk, hard, with chert. (Hård kalksten med flint).

$\left(2887^{\prime}-2924^{\prime}\right)$

891 - 914 m. Albian. Claystone and limestone, reddish brown. (Lersten og (2924'-2997') kalksten, rødligbrun). Belemnites, prisms of Inoceramus.

914 - 946 m. Barremian. Shale, black, greenish grey, micaceous. Oolites at $\left(2997^{\prime}-3103^{\prime}\right)$ base. (Lersten, sort og grønliggrå, glimmerholdig med ooliter nederst).

946 - 964 m. ?Rhaetic.

$\left(3103^{\prime}-3162^{\prime}\right)$

946 - $948 \mathrm{~m}$. Limestone and shale, thinly interbedded. Limestone green$\left(3103^{\prime}-3110^{\prime}\right)$ ish grey with calcite veins. Shale dark grey. (Kalksten, grågrøn med kalcitårer, afvekslende med tynde lag af lersten, mørkegrå). 
948 - $956 \mathrm{~m}$. Shale, mottled, black, green, yellow and red. (Lersten, $\left(3110^{\prime}-3138^{\prime}\right)$ broget, sort, grøn, gul og rød).

$956-959 \mathrm{~m}$. Limestone and claystone, thinly interbedded. Limestone $\left(3138^{\prime}-3145^{\prime}\right)$ dark grey, irregular light grey bands. Claystone light to dark grey, calcareous. (Kalksten og lersten vekslende i tynde lag. Kalkstenen er mørkegrå med uregelmæssige lysegrå bånd. Lerstenen er lysegrå til mørkegrå, kalkholdig). From the core: 956.4-958.75 m., seventeen $\mathrm{cm}$. of rock salt is reported. (I kærnen $956,5-958,75 \mathrm{~m} \mathrm{om-}$ tales $17 \mathrm{~cm}$ stensalt).

959 - $961 \mathrm{~m}$. Shale, grey, banded, mottled, calcareous. (Lersten, grå, $\left(3145^{\prime}-3153^{\prime}\right)$ tyndt lagdelt, broget, kalkholdig). 959-960 m. (3145'3150'): Ostracods (similar forms in Ullerslev No. 1, 941-980 m.).

961 - $964 \mathrm{~m}$. Shale, limestone and chalk, thinly interbedded, grey, grey$\left(3153^{\prime}-3162^{\prime}\right)$ ish white and brown. (Lersten og kalksten i afvekslende, tynde lag, grå, grålighvid og brun). Fish remains.

$964-1036 \mathrm{~m}$. Keuper. Claystone, greyish, reddish brown parts, thin laminae $\left(3162^{\prime}-3400^{\prime}\right)$ of anhydrite at ca. $1023 \mathrm{~m}$. (Lersten, grålig med rødligbrune partier og tynde lag af anhydrit ved ca. $1023 \mathrm{~m}$ ).

$1036-1096$ m. Keuper. Siltstone, brownish, micaceous, calcareous, and clay$\left(3400^{\prime}-3595^{\prime}\right)$ stone, reddish brown, greenish grey parts, anhydrite. (Finsandsten, brunlig, glimmerholdig, kalkholdig, og lersten, rødligbrun med grønliggrå partier og anhydrit).

Well geologists: H.Ø.; S.M.; A.N.N.

Micropaleontologist: O. BRUUN CHRISTENSEN

Paleontology: H.Ø.

\section{Hönning No. 1 - D.G.U. File No. 150.197.}

Gravity anomaly: Near the highest point of unnumbered residual gravity minimum trending NW-SE with a relief of $0.7 \mathrm{mgal}$. The northeastern flank of the anomaly is parallel with the contours on the southwestern flank of unnumbered residual gravity maximum with a relief of $6 \mathrm{mgal}$. The steeper gradient of the maximum is at right angles with the trend of the minimum, suggesting a fault zone separating the anomalies described.

Seismic survey: Reflection. NW-SE trending complex anticlinal structure suggested by a reflection horizon in the Upper Permian Zechstein evaporite formation. Apparent closure against a northwest-southeast trending fault suggesting more than $100 \mathrm{~km}^{2}$ of fault closure. The well was located about $4.5 \mathrm{~km}$. W of the highest point of the reflection horizon, SW of the suggested fault. 
Previous core drill results: None.

Objective: A stratigraphic test of increased section in the Zechstein and a test of the Zechstein dolomite members.

Location: Approximately $18 \mathrm{~km}$. SE of Ribe City and $9.1 \mathrm{~km}$. ENE of Skärbäk railway station. Coordinates: $55^{\circ} 10.863^{\prime} \mathrm{N}$; $3^{\circ} 40.175^{\prime} \mathrm{W}$ of Copenhagen Observatory.

Drilling: Spudded August 9, 1958; completed October 19, 1958.

Elevation: Ground $28.5 \mathrm{~m}$. Rotary table $32.4 \mathrm{~m}$.

Stratigraphy, main lithology and paleontology:

0 - $59 \mathrm{~m}$. Pleistocene. Glacial drift. (Istidsdannelser).

59 - 222 m. Miocene. Mica clay, dark grey, quartz sand and quartz gravel, bluish grey. (Glimmerler, mørkegråt, kvartssand og kvartsgrus, blågråt). Asterigerina staeschei, Epistomina elegans.

222 - 267 m. Oligocene. Mica clay, dark brown. (Glimmerler, mørkebrunt). Ceratobulimina contraria, Angulogerina sp., Cassidulina sp., Sphaeroidina variabilis.

267 - 379 m. Eocene. Clay, grey, and greenish grey, sticky, lower parts brick red. (Ler, gråt og grønliggråt, fedt, nedre del teglstensrødt).Vaginulinopsis decorata, Alabamina sp., Cibicides sulzensis.

379 - 418 m. Lower Eocene and Paleocene. Clay, grey. (Ler, gråt). Anomalinoides grosserugosa, Thurammina $c f$. crinacea.

418 - 426 m. Danian. Bryozoan limestone with chert. (Bryozokalk med flint). Osangularia lens, Cibicides voltzianus, Ataxophragmium sp.

426 - 873 m. Senonian. Chalk, white, soft, with chert, downwards with marl, greyish white. (Skrivekridt med flint, nedre del med grålighvid mergel). Pseudotextularia elegans, Bolivinoides draco draco, Buliminella laevis, Reussella pseudospinulosa, Stensioeina exsculpta, Pseudovalvulineria cf. lorneiana, Bolivina incrassata.

873 - 890 m. Turonian. Limestone, greyish white. (Kalksten, grålighvid). Ataxophragmium variabilis, Spiroplectinata jaekeli.

890 - 911 m. Cenomanian. Chalk, greyish white. (Kalksten, grålighvid). Gavelinopsis cenomanica, Cibicides of. formosus, Verneuilina sp.

911 - 916 m. Lower Cretaceous, Albian. Marl, reddish brown. (Mergel, rødlig brun). Glomospira sp., Gaudryina sp., Gavelinella sp.

916-1020 m. Aptian and Barremian. Claystone, greenish grey, dark grey. (Lersten, grønliggrå og mørkegrå). Conorotalites aptiensis, Lenticulina eichenbergi, Saracenaria spinosa.

$1020-1289$ m. Keuper. Claystone, reddish brown, minor green parts, with anhydrite, whitish grey. (Lersten, rødligbrun med mindre, grønne partier med hvidgrå anhydrit).

$1289-1449$ m. Muschelkalk. Limestone, pale grey, argillaceous, with shale, 
greenish grey, and anhydrite. (Kalksten, lysegrå, leret med lersten, grønliggrå, og anhydrit).

$1449-1991$ m. Bunter. Claystone, reddish brown, with variegated shales, minor beds of sand, reddish brown and pale green. (Lersten, rødligbrun med brogede lag og små lag af sand, rødligbrunt og lysegrønt). Core 1627-1632 m.: Chara oogoniae (casts), Ostracods (casts).

1991 -2472 m. Upper Permian, Zechstein.

1991-2004 m. A8-Anhydrite, white, soft, with claystone, reddish, brown and shale, green. (Anhydrit, hvid, blød med lersten, rødligbrun og grøn).

2004 -2006 m. A8.1-Shale, variegated, red and green, traces of dolomite, brownish grey, dense, argillaceous. (Lersten, broget, rød og grøn med spor af dolomit, brunliggrå, tæt, leret).

2006-2035 m. A8-Anhydrite, white, soft, with claystone and shale. (Anhydrit, hvid, blød med lersten).

2035 -2044 m. A5-Rock salt. (Stensalt).

2044-2064 m. A4-Anhydrite, white, soft, with shale, variegated. (Anhydrit, hvid, blød med broget lersten).

$2064-2129$ m. B5-Rock salt. (Stensalt).

2129 -2136 m. B4-Anhydrite, white, soft. (Anhydrit, hvid, blød).

2136-2159 m. B3-Dolomite, greyish brown, dense, argillaceous, with irregular, thin bands of anhydrite. At $2143 \mathrm{~m}$. (core No. 4): slight fluorescence and cut with $\mathrm{CCl}_{4}$. (Dolomit, gråligbrun, tæt, leret med uregelmæssige, tynde bånd af anhydrit. Ved $2143 \mathrm{~m}$ (kærne nr. 4): svag fluorescens og oliereaktion med $\mathrm{CCl}_{4}$ ).

2159-2171 m. B1-Shale, greenish grey, and reddish brown, with thin laminae of dolomite and rock salt. (Lersten, grønliggrå og rødligbrun med tynde lag af dolomit og stensalt).

$2171-2175$ m. C8-Anhydrite. (Anhydrit).

2175 -2226 m. C5-Rock salt. (Stensalt).

2226 -2270 m. C4-Anhydrite, white, non-crystalline. (Anhydrit, hvid, ikkekrystallin).

2270-2283 m. C3-Dolomite, greyish brown, dense, anhydritic, fair fluorescence, slight oil cut, petroliferous odour, no gas. (Dolomit, gråligbrun, tæt, anhydritisk, god fluorescens, svag oliereaktion, olielugt, ingen luftformige kulbrinter).

2283 -2286 m. C1-2-Claystone, reddish brown, inclusions of shale, green, slightly calcareous. (Lersten, rødligbrun med partier af grøn lersten, kalkholdig).

2286 -2287 m. D9-Dolomite, greyish brown, very anhydritic. At $2286.5 \mathrm{~m}$. (core No. 7): fair fluorescence, slight oil cut, petroliferous 
odour. (Dolomit, gråligbrun, meget anhydritisk. Ved 2286,5 m (kærne nr. 7): god fluorescens, svag oliereaktion, olielugt).

2287 -2361 m. D4-8-Anhydrite, greyish white, lower part with shale, variegated (red and green) and with traces of dolomite, grey, dense. (Anhydrit, grålighvid, nedre del med lersten, broget (rød og grøn) og spor af dolomit, grå, tæt).

$2361-2375$ m. D3-Dolomite, grey; thin dark carbonaceous partings. Oil staining along fractures. Slight fluorescence. (Dolomit, grå, i lag adskilt af tynde sorte lag. Oliepletter langs sprækker. Svag fluorescens).

2375 -2397 m. D2-Dolomitic Limestone, light grey, laminated. Basal part: limestone dominating. (Dolomitisk kalksten, lysegrå, lagdelt. Nederst dominerer kalksten).

$2397-2452$ m. E4-Anhydrite, white, soft, in top part with dolomite and oolites (E9-Dolomite?). 2422-2428 m.: Anhydrite with shale, red and green. (Anhydrit, hvid, blød, i øvre del med dolomit og ooliter (E9-Dolomit?). Ved 2422-2428 $\mathrm{m}$ : Anhydrit med rød og grøn lersten).

2452 -2468 m. E3-Dolomite, grey, dense. (Dolomit, grå, tæt).

$2468-2472$ m. E1-3-Dolomitic conglomerate, with milky quartz inclusions, biotite and galena. Bedding approximately horizontal. (Dolomit-konglomerat med indeslutninger af "mælket" kvarts, biotit og blyglans. Lagdeling omtrent horisontal). 2472-2486 m. Pre-Zechstein. Claystone and shale, dark grey to reddish brown, dip $37^{\circ}$. (Lersten, mørkegrå til rødligbrun, hældning $37^{\circ}$.

Well geologists: A.F.B.; L.B.R.; L.J.A.; A.D.

Micropaleontologist: A.B.

Schlumberger interpreters: A.F.B.; J.M.D.; T.S.

\section{Horsens No. 1 - D.G.U. File No. 107.219.}

Gravity anomaly: Structure not related to any apparent gravity anomaly.

Seismic survey: Reflection. A closed elongate structure with WNW-ESE trend is indicated by a reflection horizon near the base of the Upper Cretaceous. From the flattened top area the steeper gradients are to the SE, S, and SW, and a more moderate gradient to the $\mathrm{W}$ and $\mathrm{N}$. The suggested structure covers about $50 \mathrm{~km}^{2}$. of closed area. The well has been located $\mathrm{S}$ of the crest near the northwestern centre. An E-W fault in the southern flank is possible. Questionable faulting in the northwestern flank with poor control.

Previous core drill results: None. 
Objective: To test the Lower Cretaceous-Jurassic-Rhaetic sequence for oil and gas accumulations.

Location: Approximately 9 km. NNE of Horsens City; $150 \mathrm{~m}$. N of Örskov village. Coordinates: $55^{\circ} 56.185^{\prime} \mathrm{N} ; 2^{\circ} 40.446^{\prime} \mathrm{W}$ of Copenhagen Observatory.

Drilling: Spudded July 13, 1958; completed July 31, 1958.

Elevation: Ground $53.5 \mathrm{~m}$. Rotary table $56.8 \mathrm{~m}$.

Stratigraphy, main lithology and paleontology:

0 - $167 \mathrm{~m}$. Pleistocene. Glacial drift. (Istidsdannelser).

167 - 202 m. Eocene. Clay, light grey, greenish grey, dark grey. (Ler, lysegråt, grønliggråt, mørkegråt).

202 - 217 m. Paleocene. Shale, dark grey. (Skiferler, mørkegråt).

217 - 469 m. Danian. Bryozoan limestone with chert. (Bryozokalk med flint).

$469-1146$ m. Senonian-Turonian. Chalk, white, soft, with chert, lower parts with marl, pale green; limestone, light grey. (Skrivekridt med flint, nedre del kalksten, lysegrå og lysegrøn mergel). Bolivina incrassata, Stensioeina pommerana, Neoflabellina rugosa, Stensioeina exsculpta, Globotruncana spp.

$1146-1165$ m. Cenomanian. Limestone, greenish white, glauconitic, with marl, pale greyish green, and shale, dark grey. (Kalksten, grønlighvid, glaukonitisk med lys gråliggrøn mergel og mørkegrå lersten). Gavelinopsis cenomanica, Globotruncana spp., Arenobulimina sp.

1165-1170 m. Albian-Aptian. Marl and shale, reddish brown. (Mergel og lersten, rødligbrun). Glomospira sp., Gavelinella sp., Tritaxia sp., Saracenaria bronnii.

1170 -1309 m. Middle Jurassic, Dogger. Shale, dark grey, brownish grey, sand and siltstone, pale green, glauconitic. (Lersten, mørkegrå, brunliggrå, sand og finsandsten, lysegrøn, glaukonitisk). Reinholdella $c f$. dreheri, Planularia sp.

1309 -1569 m. Lower Jurassic, Lias. Shale, dark grey, greyish black, with beds of shale, dark brown. Basal parts: with sand and siltstone, dark grey. (Lersten, mørkegrå, gråsort med lag af mørkebrun lersten. Nedre del med sand og finsandsten, mørkegrå). Marginulina prima, Dentalina matutina, Planularia inaequistriata, Planularia stilla.

$1569-1642$ m. Rhaetic. Sandstone and siltstone, grey, laminated with shale, greyish black, bands of lignite. Shale, light grey, and dark grey, with brownish bands; basal parts with bands of limestone, pale grey. (Sandsten og finsandsten, grå afvekslende i tynde lag med lersten, gråsort med tynde kulførende bånd. Lersten, lysegrå og mørkegrå med brunlige bånd. Nederste dele med bånd af lysegrå kalksten). Ostracods. 
$1642-1726$ m. Keuper. Claystone and shale, rust brown and variegated, with gypsum. (Lersten, rustbrun og broget, med gips).

Well geologists: A.F.B.; J.M.D.; A.D.

Micropaleontologist: A.B.

Schlumberger interpreters: A.F.B.; J.M.D.

\section{Lavö No. 1 - D.G.U. File No. 186.165.}

Gravity anomaly: About $6 \mathrm{~km}$. W of the centre of residual gravity minimum "AU" with a negative relief of about $2 \mathrm{mgal}$, about $5 \mathrm{~km}$. S of the centre of residual gravity maximum " 51 " with a positive relief of about 4 mgal.

Seismic survey: Reflection. The reflection horizon near the base of the Upper Cretaceous suggests a closed structure with a minimum closure of about $20 \mathrm{~m}$. on the crest of an anticline trending WNW. The southwestern flank is probably cut by a fault parallel to the trend, leaving the structure on the downthrown side. Another fault is suggested to cut the flank to the NE, but seismic control is very poor.

Previous core drill results: None.

Objective: To test the Lower Cretaceous-Jurassic-Rhaetic sequence for hydrocarbons and to test the Jurassic for source bed studies.

Location: $2.2 \mathrm{~km}$. NW of Helsinge railway station and $0.8 \mathrm{~km}$. SW of Lavö village. Coordinates: $56^{\circ} 01.970^{\prime} \mathrm{N} ; 0^{\circ} 24.150^{\prime} \mathrm{W}$ of Copenhagen Observatory.

Drilling: Spudded January 19, 1959; completed March 1, 1959.

Elevation: Ground $25 \mathrm{~m}$. Rotary table $28.3 \mathrm{~m}$.

Stratigraphy, main lithology and paleontology:

0 - $67 \mathrm{~m}$. Pleistocene. Glacial drift. (Istidsdannelser).

67 - 147 m. Danian. Calcarenite and limestone, whitish grey, sandy. (Kalksandskalk og hvidgrå, sandet kalksten). Osangularia lens.

$147-1866 \mathrm{~m}$. Senonian. Chalk, white, soft, with chert, downwards with beds of marl, grey; lower half: limestone, grey, argillaceous. (Skrivekridt med flint, nedefter med lag af grå mergel; nederste halvdel: kalksten, grå, leret). Pseudotextularia elegans, Buliminellalaevis, Bolivinoides draco draco, Stensioeina pommerana, Stensioeina exsculpta, Globotruncana ventricosa.

$1866-1940 \mathrm{~m}$. ?Turonian. Limestone, white, in basal part with shale, dark greenish grey, glauconitic. (Kalksten, hvid, nederst med lersten, mørk grønliggrå, glaukonitisk). Globotruncana spp., Arenobulimina sp., Gyroidina sp.

1940 -1996 m. Cenomanian-Albian. Siltstone, grey, and shale, dark greenish grey. Basal part: sandstone, green, glauconitic. (Finsandsten, grå og lersten, mørk grønliggrå; nederst sandsten, grøn, glau- 
konitisk). Globigerina sp., Gaudryina sp., Ammobaculites sp., Haplophragmoides sp., Glomospira sp.

1996 -2069 m. Lower Cretaceous. Sandstone, whitish grey, shale, dark grey, brownish grey. (Sandsten, hvidliggrå og lersten, mørkegrå og brunliggrå). Haplophragmoides sp., Gaudryina sp., Ammobaculites $s p$.

2069 -2290 m. Lower Jurassic, Lias. Shale, dark greenish grey, siltstone, light grey. (Lersten, mørk grønliggrå og finsandsten, lysegrå). Planularia stilla, Dentalina matutina, Ammodiscus incertus.

$2290-2365$ m. ?Rhaetic. Shale, greenish grey, brownish grey, greyish black. (Lersten, grønliggrå, brunliggrå, gråsort).

2365-2438 m. ?Keuper. Claystone, variegated, reddish brown, green and yellow, and sandstone, pale green. (Lersten, broget, rødligbrun, grøn og gul, og sandsten, lysegrøn).

Well geologists: A.F.B.; A.D.

Micropaleontologist: A.B.

Schlumberger interpreters: A.F.B.; J.M.D.

\section{Ringe No. 1 - D.G.U. File No. 146.169.}

Gravity anomaly: Located about $1.5 \mathrm{~km}$. SW of the centre of gravity maximum " 53 " interpreted as the expression of a NW-SE trending fault block with shallow basement.

Seismic survey: a. Reflection. The NW-SE trending faulted structure was confirmed by the reflection survey. The structure is bounded by a conspicuous fault to the SW; displacement increases with depth. The well is located near the centre of a structural crest suggested by a deep reflection horizon. Reflection horizon " $\mathrm{A}$ " near the base of the Upper Cretaceous is strikingly unconformable with all subjacent horizons. The fault block dips to the NE. Pinch-outs are found.

b. Refraction. Basement suggested at 4000' (ca. 1220 m.) sub-sea on NW-SE trending refraction profile. Anticlinal reversal in both 2360 and $5900 \mathrm{~m}$./s. markers. Approximately $150^{\prime}$ (ca. $46 \mathrm{~m}$.) of positive relief indicated at the level of the $5900 \mathrm{~m}$./s. marker.

Subsurface geology: The Danian-Paleocene contact has been mapped on the basis of water well data. This level indicates an anticlinal structure coincident with gravity anomaly " 53 ".

Objective: Stratigraphic test to the basement with the purpose of a special investigation of the Lower Cretaceous-Jurassic-Triassic interval.

Location: $16 \mathrm{~km}$. SE of Odense Central station, and $5 \mathrm{~km}$. NNE of Ringe railway station. Coordinates: $55^{\circ} 16.89^{\prime} \mathrm{N} ; 2^{\circ} 04.30^{\prime} \mathrm{W}$ of Copenhagen $\mathrm{Ob}-$ servatory.

Drilling: Spudded February 4, 1951; completed April 19, 1951.

Elevation: Ground 73.5 m. $\left(241^{\prime}\right)$. Rotary table 76.8 m. $\left(252^{\prime}\right)$. 
Stratigraphy, main lithology and paleontology:

0 - $85 \mathrm{~m}$. Pleistocene. Glacial drift. (Istidsdannelser).

$\left(0^{\prime}-279^{\prime}\right)$

85 - 91 m. Paleocene. Marl, light grey. (Mergel, lysegrå). Pseudovalvuli$\left(279^{\prime}-298^{\prime}\right)$ neria sp.

91 - 141 m. Danian. Bryozoan limestone with chert. (Bryozokalk med flint). (298'- 464') "Discorbis" binkhorsti.

$141-819$ m. Senonian-Turonian. Chalk, white, soft, with chert; limestone, $\left(464^{\prime}-2687^{\prime}\right)$ white, soft, interlaminated with greenish marl. (Skrivekridt med flint og kalksten, hvid, blød med tynde lag af grønlig mergel). Stensioeina pommerana, Bolivina incrassata, Bolivinoides draco draco, Angulogavelinella bettenstedti, Reussella pseudospinulosa, Pseudovalvulineria of. lorneiana, Globorotalites $c f$. michelinianus, Stensioeina exsculpta.

819 - 826 m. Cenomanian-Albian. Claystone, brownish grey, greenish grey. $\left(2687^{\prime}-2711^{\prime}\right)$ (Lersten, brunliggrå, grønliggrå). Gavelinopsis cenomanica, Arenobulimina sp., Globigerina spp.

826 - 835 m. Lower Cretaceous, Albian. Claystone, reddish brown. (Lersten, (2711'-2739') rødligbrun). Arenobulimina sp., Planulina sp., Glomospira sp., Spiroplectinata sp.

835 - 840 m. Lower Cretaceous. Siltstone, greenish black, argillaceous, glau$\left(2739^{\prime}-2756^{\prime}\right)$ conitic, limonite spheres near base. (Siltsten, grønligsort, leret, glaukonitisk med limonitsfæroliter nederst).

$840-1268 \mathrm{~m}$. Triassic.

$\left(2756^{\prime}-4161^{\prime}\right)$

840 - $902 \mathrm{~m}$. Claystone, varicoloured, greyish brown, greyish green.

$\left(2756^{\prime}-2959^{\prime}\right)$ (Lersten, broget, gråligbrun, gråliggrøn).

$902-1114 \mathrm{~m}$. Claystone, varicoloured, light green, reddish brown, beds,

$\left(2959^{\prime}-3654^{\prime}\right)$ lumps, and seams of gypsum and anhydrite. (Lersten, broget, lysegrøn, rødligbrun, med lag, knolde og bånd af gips og anhydrit).

$1114-1137 \mathrm{~m}$. Dolomite and claystone, dolomitic, beds and seams of $\left(3654^{\prime}-3729^{\prime}\right)$ anhydrite. (Dolomit og dolomitisk lersten med lag og bånd af anhydrit).

$1137-1268 \mathrm{~m}$. Claystone, reddish brown, green spots, sand content in-

$\left(3729^{\prime}-4161^{\prime}\right)$ creasing downwards. (Lersten, rødligbrun med grønne pletter, nedefter med forøget sandindhold).

$1268-1277 \mathrm{~m}$. ?Permian. Sandstone, fine to coarse grained, reddish brown. $\left(4161^{\prime}-4190^{\prime}\right) \quad$ (Sandsten, finkornet til grovkornet, rødligbrun).

$1277-1437$ m. Lower Permian or Eocambrian. Sandstone and arkose, vari$\left(4190^{\prime}-4715^{\prime}\right)$ coloured, felspar content increasing downwards, kaolinitic banded. At base vertical seams of calcite, locally with chips 
of granite. (Sandsten og arkose, broget, nedefter med forøget indhold af feldspat og med kaoliniserede bånd. Nederst med lodrette kalcitbånd og brudstykker af granit).

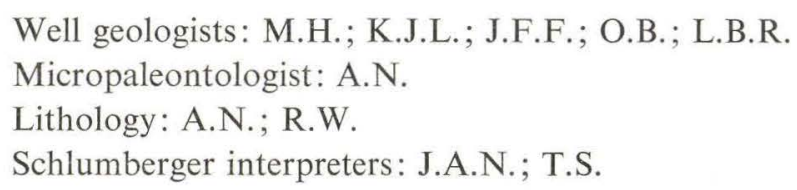

Rödby No. 1 - D.G.U. File No. 240.75.

Gravity anomaly: Located on the culmination of residual gravity maximum " 29 " interpreted as a structural uplift.

Seismic survey: No seismic surveys had been carried out when the well was spudded in.

Subsurface geology: The centre of gravity anomaly " 29 " coincides with an area in which shallow water wells encountered Upper Cretaceous Chalk, while Eocene clay was encountered below glacial drift outside the Chalk area. This suggested gravity maximum " 29 " to be a structural uplift.

Objective: Stratigraphic test; strict wildcat.

Location: $500 \mathrm{~m}$. SE of Rödby railway station. Coordinates: $54^{\circ} 41.62^{\prime} \mathrm{N}$; $1^{\circ} 10.37^{\prime} \mathrm{W}$ of Copenhagen Observatory.

Drilling: Spudded January 11, 1952; completed March 24, 1952.

Elevation: Ground $2.1 \mathrm{~m}$. ( $\left(7^{\prime}\right)$. Rotary table $5.5 \mathrm{~m} .\left(18^{\prime}\right)$.

Stratigraphy, main lithology and paleontology:

0 - 29 m. Pleistocene. Glacial drift. (Istidsdannelser).

$\left(0^{\prime}-95^{\prime}\right)$

29 - $439 \mathrm{~m}$. Senonian-Turonian. Chalk, white, soft, with chert; and lime$\left(95^{\prime}-1439^{\prime}\right)$ stone, white, soft, with laminae and bands of greenish marl. Basal 13 m.: marl, greenish grey, sticky. (Skrivekridt med flint og kalksten, hvid, blød med tynde lag af grønlig mergel. Nederste $13 \mathrm{~m}$ : mergel, grønliggrå, fed). Angulogavelinella bettenstaedti, Reussella pseudospinulosa, Pseudovalvulineria c $f$. lorneiana, Globorotalites michelinianus, Stensioeina exsculpta, Globotruncana spp.

439 - 459 m. Cenomanian Limestone, white, soft, much marl, greenish, soft. $\left(1439^{\prime}-1506^{\prime}\right) \quad$ (Kalksten, hvid, blød, med meget mergel, grønlig, blød). Gavelinopsis cenomanica.

459 - 469 m. Lower Cretaceous, Albian. Claystone, reddish brown, with $\left(1506^{\prime}-1538^{\prime}\right)$ green parts. (Lersten, rødligbrun med grønne partier). Gavelinella $s p$. 
469 - 557 m. Lower Jurassic, Lias.

$\left(1538^{\prime}-1826.5^{\prime}\right)$

$469-470 \mathrm{~m}$. Silt, argillaceous, varicoloured, red, reddish, yellowish,

$\left(1538^{\prime}-1541^{\prime}\right)$ greenish. (Finsand, leret, broget, rødt, rødligt, gulligt og grønligt).

470 - $531 \mathrm{~m}$. Clay, dark grey, greyish black, interbedded with sand, $\left(1541^{\prime}-1741^{\prime}\right)$ fine grained, light grey. (Ler, mørkegråt, gråsort, afvekslende med sand, fint, lysegråt). Geinitzina tenera tenuistriata, Ostracods, Holothurian plates, Spandelina bicostata bicostata, Astacolus varians convolutus, Megaspores, Dentalium sp., small gastropods, young Ostreid s. l., Pelecypods, Dentalina sp., Marginulina (sp. indet.).

$531-532 \mathrm{~m}$. Silt, grey, sandy, with carbonaceous streaks, $0.5 \mathrm{~cm}$. $\left(1741^{\prime}-1744\right.$ ') horizon of fish teeth and scales ("Bone bed"). (Finsand, gråt, sandet med mørktfarvede striber, $0.5 \mathrm{~cm}$ horisont af fisketænder og fiskeskæl ("Bone bed")). Plant remains, Hybodus sp., Saurichtys sp., Trochammina sp.

$532-545 \mathrm{~m}$. Claystone and shale, dark greenish grey, locally lenses of $\left(1744^{\prime}-1787^{\prime}\right) \quad$ fine grained sand. (Lersten, mørk grønliggrå, med enkelte linser af fint sand).

$545-547 \mathrm{~m}$. Lower to Middle Lias gamma, (jamesoni-ibex zone). $\left(1787^{\prime}-1796^{\prime}\right) \quad$ Claystone, shaly, grey, and silt, light grey. (Lersten, skifret, grå og siltsten, lysegrå). Palaeoneilo galatea, Grammatodon cypriniformis, Astarte cf. ryensis, Chlamys interpunctata, Beaniceras "centaurus", Marginulinopsis ( $s p$. indet.), Astacolus varians convolutus, Eoguttulina liassica, Lamarckina nov. sp., Geinitzina tenera tenuistriata, Astacolus sp., Trochammina sp.

547 - 557 m. Lias alpha. Claystone, silty, shaly, dark grey. (Lersten, fin$\left(1796^{\prime}-1826,5^{\prime}\right)$ sandet, skifret, mørkegrå). Geinitzina tenera tenuistrata, Eoguttulina liassica.

547 - $550 \mathrm{~m}$. ?Liostrea irregularis.

$\left(1796^{\prime}-1805,5^{\prime}\right)$

553 - 554 m. Lias alpha 1, (planorbis zone). Protocardium phillippiana, (1814'-1816') Psiloceras planorbis.

556 - 557 m. Lias, (pre-planorbis zone). Modiola minuta, Eotrapezium

$\left(1824^{\prime}-1826,5^{\prime}\right)$ hyllingense, ?Liostrea irregularis.

557 - 713 m. Rhaetic.

$\left(1826.5^{\prime}-2339^{\prime}\right)$

$557-686 \mathrm{~m}$. Sand, fine grained, argillaceous, light grey, interbedded

$\left(1826,5^{\prime}-2249^{\prime}\right)$ with clay, silty, greenish grey. (Sand, fint, leret, lysegråt afvekslende med ler, finsandet, grønliggråt). Megaspores with circular fold. 
$686-713 \mathrm{~m}$. Claystone, interbedded with sand and sandstone, light $\left(2249^{\prime}-2339^{\prime}\right)$ grey, calcareous, in basal parts with shale and silt.

(Lersten afvekslende med sand og sandsten, lysegrå, kalkholdig, i nedre del med lersten og finsand). Plant remains, Ostracod C, Ostracod F, Fish remains.

713 - $784 \mathrm{~m}$. Keuper. Claystone, light greenish grey to light green, with $\left(2339^{\prime}-2573^{\prime}\right)$ brownish parts, with anhydrite. (Lersten, lys grønliggrå til lysegrøn, med brunlige partier og med anhydrit). Estheria $s p$,

784 - 967 m. Muschelkalk.

$\left(2573^{\prime}-3174^{\prime}\right)$

$784-862 \mathrm{~m}$. Marlstone, greenish grey, occasionally with beds of lime-

$\left(2573^{\prime}-2829^{\prime}\right)$ stone, light grey, and concretionary anhydrite. (Mergelsten, grønliggrå, med underordnede lag af kalksten, lysegrå, og knolde af anhydrit). Fish scales, Megafossils (poorly preserved).

$862-967 \mathrm{~m}$. Limestone, pale green, greenish grey, interbedded with $\left(2829^{\prime}-3174^{\prime}\right)$ claystone, green to pale greenish grey. (Kalksten, lysegrøn til grønliggrå afvekslende med lersten, grøn til lys grønliggrå). Brachiopods and Pelecypods (poorly preserved).

$967-1531$ m. Bunter.

$\left(3174^{\prime}-5024^{\prime}\right)$

$967-1091$ m. Röt. Claystone, varicoloured, dark brown and green, with

$\left(3174^{\prime}-3580^{\prime}\right)$ anhydrite. (Lersten, broget, mørkebrun og grøn, med anhydrit).

$1091-1126$ m. Röt. Limestone, argillaceous, dolomitic, light grey to pale $\left(3580^{\prime}-3694^{\prime}\right)$ greenish grey, interbedded with claystone, greenish, calcareous. (Kalksten, leret, dolomitisk, lysegrå til lys grønliggrå, vekslende med lersten, grønlig, kalkholdig).

$1126-1139$ m. Röt. Claystone, light greenish grey, calcareous, with an$\left(3694^{\prime}-3736^{\prime}\right) \quad$ hydrite. (Lersten, lys grønliggrå, kalkholdig, med anhydrit).

$1139-1162 \mathrm{~m}$. Sand, fine grained, reddish brown with green portions. $\left(3736^{\prime}-3811^{\prime}\right) \quad$ (Sand, fint, rødligbrunt med grønne partier).

$1162-1206 \mathrm{~m}$. Siltstone, argillaceous, reddish brown, bands of calcareous

$\left(3811^{\prime}-3957^{\prime}\right) \quad$ sandstone. (Finsandsten, leret, rødligbrun med bånd af kalkholdig sandsten). Chara oogoniae.

$1206-1232 \mathrm{~m}$. Sandstone, fine grained, argillaceous, reddish brown with $\left(3957^{\prime}-4043^{\prime}\right)$ green portions. (Sandsten, finkornet, leret, rødligbrun med grønne partier).

$1232-1531 \mathrm{~m}$. Siltstone and sandstone, interbedded with claystone, silty, $\left(4043^{\prime}-5024^{\prime}\right)$ reddish brown, with green portions, locally oolitic. (Finsandsten og sandsten, vekslende med lersten, finsandet, rødligbrun med grønne partier, stedvis oolitisk). 


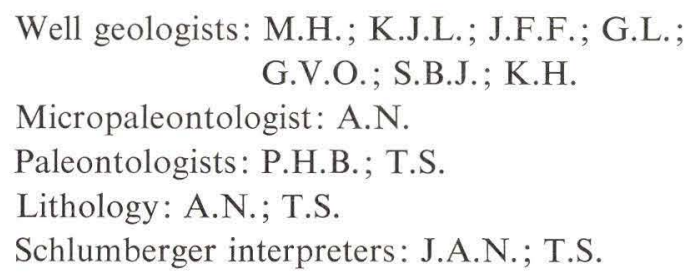

Rödby No. 2 - D.G.U. File No. 240.77.

Gravity anomaly: Located near the centre of residual gravity maximum " 29 " with a positive relief of $2.5 \mathrm{mgal}$.

Seismic survey: a. Reflection. A well defined anticlinal uplift practically coincident with gravity anomaly "29". Closure of about 400' (ca. $122 \mathrm{~m}$.) near the top of the Lower Cretaceous. Slight convergence between the top of the Lower Cretaceous and the Rhaetic.

b. Refraction. Refraction profile "LF-13" confirmed the situation as mapped during the reflection survey, although the profile was not carried far enough to the east to confirm closure.

Previous core drill results: None. Structure evident from the subsurface geological map (see Rödby No. 1).

Objective: A test of the entire Zechstein. (The Jurassic was tested in Rödby No. 1, and the difference in location between Rödby No. 1 and 2 as to the structural position was negligible).

Location: About $2 \mathrm{~km}$. WSW of Rödby railway station and $2.1 \mathrm{~km}$. W to $\mathrm{S}$ of Rödby No. 1 (File No. 240.75). Coordinates: $54^{\circ} 41.49^{\prime} \mathrm{N} ; 1^{\circ} 12.30^{\prime} \mathrm{W}$ of Copenhagen Observatory.

Drilling: Spudded April 20, 1953; completed October 24, 1953.

Elevation: Ground 2.7 m. (9'). Rotary table 7.9 m. (26').

Stratigraphy, main lithology and paleontology:

$0-143 \mathrm{~m}$. Pleistocene. Glacial drift. (Istidsdannelser).

$\left(0^{\prime}-468^{\prime}\right)$

143 - 422 m. Senonian-Turonian. Chalk, white, soft, with chert, downwards $\left(468^{\prime}-1383^{\prime}\right)$ with bands of marl, greenish, basal: marl, greenish grey to grey. (Skrivekridt med flint, nedefter med bånd af grønlig mergel og nederst: mergel, grønliggrå til grå). Pseudovalvulineria cf. lorneiana, Globorotalites michelinianus, Stensioeina exsculpta, Globotruncana spp.

422 - 438 m. Cenomanian. Limestone, white, streaks of marl, pale greenish $\left(1383^{\prime}-1436^{\prime}\right)$ grey and pink. (Kalksten, hvid med striber af mergel, lys grønliggrå og rosa). Gavelinopsis cenomanica. 
438 - 448 m. Lower Cretaceous, Albian. Marlstone, reddish brown, green $\left(1436^{\prime}-1469^{\prime}\right)$ parts. (Mergelsten, rødligbrun med grønne partier). Arenobulimina sp., Gavelinella sp.

448 - 528 m. Lower Jurassic, Lias.

$\left(1469^{\prime}-1733^{\prime}\right)$

448 - 502 m. Clay, dark to light grey, sandy, silty; sand, fine grained,

$\left(1469^{\prime}-1648^{\prime}\right)$ and sandstone, light grey. Lignite. (Ler, mørkegråt til lysegråt, sandet, og finkornet sand og sandsten, lysegrå, med lignit). Geinitzina tenera.

$502-528 \mathrm{~m}$. Claystone, shaly, dark to light grey. (Lersten, mørkegrå $\left(1648^{\prime}-1733^{\prime}\right)$ til lysegrå).

$528-693$ m. Rhaetic.

$\left(1733^{\prime}-2275^{\prime}\right)$

$528-559 \mathrm{~m}$. Claystone, greenish grey, with frequent beds and bands

$\left(1733^{\prime}-1833^{\prime}\right)$ of sand, fine grained, light grey. (Lersten, grønliggrå, med talrige lag og bånd af fint sand, lysegråt).

559 - 693 m. Sand, light grey, fine grained, some bands of clay. Basal

$\left(1833^{\prime}-2275^{\prime}\right)$ part: sandstone, limestone, claystone, interbedded, many bands of lignite. (Sand, lysegråt, fint med bånd af ler; nederst: sandsten, kalksten og lersten i vekslende lag, mange lignitiske bånd). Ostracod F.

693 - $767 \mathrm{~m}$. Keuper. Claystone, light greenish grey, occasionally brownish; $\left(2275^{\prime}-2518^{\prime}\right)$ anhydrite. (Lersten, lys grønliggrå, stedvis brunlig, med anhydrit).

767 - 946 m. Muschelkalk. Claystone, grey to green, limestone, argillaceous, $\left(2518^{\prime}-3103^{\prime}\right)$ grey to greenish grey, and shale, interbedded. (Lersten, grå til grøn og kalksten, grå til grønliggrå, leret i afvekslende lag).

$946-1657$ m. Bunter.

$946-1065 \mathrm{~m}$. Röt. Claystone, chocolate brown, reddish brown, with

$\left(3103^{\prime}-3493^{\prime}\right) \quad$ anhydrite. (Lersten, mørkebrun, rødligbrun med anhydrit). Chara oogoniae.

1065 -1102 m. Röt. Claystone, dark brown, limestone, grey, hard, and $\left(3493^{\prime}-3615^{\prime}\right)$ sandstone, grey, hard, interbanded with anhydrite. (Lersten, mørkebrun, kalksten, grå, hård og sandsten, grå, hård, afvekslende med anhydritbånd).

$1102-1112$ m. Röt. Claystone, greenish grey, silty, calcareous, with an$\left(3615^{\prime}-3649^{\prime}\right)$ hydrite. (Lersten, grønliggrå, finsandet, kalkholdig, med anhydrit).

$1112-1129 \mathrm{~m}$. Sand, chocolate brown, argillaceous, with beds of shale, $\left(3649^{\prime}-3703^{\prime}\right)$ greenish grey, hard, and thin bands of sandstone, hard, calcareous. (Sand, mørkebrunt, leret med lag af lersten, grønliggrå, hård og tynde sandstensbånd, hårde, kalkholdige). 
$1129-1171 \mathrm{~m}$. Claystone, chocolate brown to reddish brown, with $\left(3703^{\prime}-3843^{\prime}\right)$ greenish grey portions, with few bands of sandstone, with anhydrite. (Lersten, mørkebrun til rødligbrun med grønne partier og få sandstensbånd og med anhydrit). Chara oogoniae.

$1171-1199 \mathrm{~m}$. Sandstone, brown to grey, interbedded with siltstone, $\left(3843^{\prime}-3933^{\prime}\right)$ reddish brown and greenish grey, calcareous, with anhydrite. Oolites. (Sandsten, brun til grå, afvekslende med finsandsten, rødligbrun og grønliggrå, kalkholdig, anhydritisk).

$1199-1309 \mathrm{~m}$. Sandy siltstone and claystone, reddish brown and greenish $\left(3933^{\prime}-4293^{\prime}\right)$ grey, calcareous, micaceous. (Finsandsten og lersten, rødligbrun og grønliggrå, kalkholdig, glimmerholdig).

$1309-1340 \mathrm{~m}$. Sandstone, reddish brown and green, hard, calcareous, $\left(4293^{\prime}-4395^{\prime}\right)$ interbanded with siltstone and claystone, reddish brown, micaceous, anhydritic. (Sandsten, rødligbrun og grøn, hård, kalkholdig med finsandstens- og lerstensbånd, rødligbrune, glimmerholdige, anhydritiske).

$1340-1657 \mathrm{~m}$. Claystone, silty, reddish brown, with green portions, $\left(4395^{\prime}-5436^{\prime}\right)$ calcareous, with beds of oolitic limestone, hard, tight; basal part with increasing content of anhydrite. (Lersten, finsandet, rødligbrun med grønne partier, kalkholdig med lag af oolitisk kalksten, hård, tæt, nederst med stigende indhold af anhydrit).

\section{7 -2677 m. Upper Permian, Zechstein.} $\left(5436^{\prime}-8782^{\prime}\right)$

1657 -1658 m. A8-Anhydrite, white to pinkish, massive. (Anhydrit, hvid, $\left(5436^{\prime}-5439^{\prime}\right)$ rosa, massiv).

1658-1729 m. A5-7-Rock salt interbedded with anhydrite and clay. $\left(5439^{\prime}-5672^{\prime}\right) \quad$ (Stensalt, skiftende med anhydrit og lerlag).

1658-1664 m. Rock salt, colourless to pinkish, stringers of clay and $\left(5439^{\prime}-5458^{\prime}\right)$ anhydrite. (Stensalt, farveløst til rødligt, med striber af ler og anhydrit).

$1664-1708 \mathrm{~m}$. Clay, shaly, red, silty, beds and stringers of rock salt and $\left(5458^{\prime}-5603^{\prime}\right)$ anhydrite. (Ler med lersten, rødt, finsandet, og lag og striber af stensalt og anhydrit).

$1708-1723$ m. Rock salt, clear to pink. (Stensalt, klart til lyst rødligt). $\left(5603^{\prime}-5653^{\prime}\right)$

$1723-1726 \mathrm{~m}$. Anhydrite, probably with rock salt. (Anhydrit, sandsynlig$\left(5653^{\prime}-5662^{\prime}\right)$ vis med stensalt).

$1726-1729 \mathrm{~m}$. Clay, reddish brown and greenish, very soft, probably $\left(5662^{\prime}-5672\right.$ ') with chloride minerals. (Ler, rødligbrunt og grønligt, meget blødt, sandsynligvis med kloridmineraler). 
$1729-1779$ m. A5-Rock salt, clear to pinkish, some anhydrite. (Stensalt, $\left(5672^{\prime}-5836^{\prime}\right) \quad$ klart, farveløst til lyst rødligt, med anhydrit).

$1779-1787 \mathrm{~m}$. A4-Anhydrite, light grey, brownish, much included rock

$\left(5836^{\prime}-5862^{\prime}\right)$ salt. (Anhydrit, lysegrå til brunlig med mange indeslutninger af stensalt).

$1787-1846$ m. B5-Rock salt, colourless to orange, rather much anhydrite $\left(5862^{\prime}-6058^{\prime}\right)$ in thin beds at top and bottom. (Stensalt, farveløst til orange med ret mange tynde lag af anhydrit øverst og nederst $\mathrm{i}$ intervallet).

1846-1908 m. B4-Anhydrite, dolomitic, light to dark grey, brownish $\left(6058^{\prime}-6259^{\prime}\right)$ parts, small inclusions of rock salt throughout. (Anhydrit, dolomitisk, lysegrå til mørkegrå, med brunlige partier og små indeslutninger af stensalt).

1908 -1910 m. B3-Dolomite, calcareous, greyish brown, colloform gran$\left(6259^{\prime}-6266^{\prime}\right)$ ular to earthy texture, euryhaline megafossils. (Dolomit, kalkholdig, gråbrun, kolloform granulær til jordagtig tekstur, med euryhaline megafossiler).

1910 -1911 m. B1-Clay, shaly, dark grey, soft to tough. (Ler med lersten, (6266'-6268') mørkegråt, blødt til sejgt).

1911 -1916 m. C8-9-Anhydrite-Dolomite, grey, beds and bands of dolo$\left(6268^{\prime}-6287^{\prime}\right)$ mite, very fine grained. (Anhydrit, grå med lag og bånd af dolomit, meget finkornet).

1916-2609 m. C5-7-Rock salt, orange at very top, otherwise clear, colour$\left(6287^{\prime}-8560^{\prime}\right)$ less to milky, seams and distributions of anhydrite. (Stensalt, allerøverst orange, ellers klart og farveløst til uigennemsigtigt med striber og spredt indhold af anhydrit).

$2609-2657 \mathrm{~m}$. C4-Anhydrite, dolomitic, lower half interbedded with

$\left(8560^{\prime}-8716^{\prime}\right)$ dolomite. (Anhydrit, dolomitisk, i nedre halvdel vekslende med dolomit).

2657 -2659 m. C3-Dolomite, dolomitic limestone. (Dolomit og dolomitisk $\left(8716^{\prime}-8723^{\prime}\right) \quad$ kalksten).

2659 -2671 m. C2-Limestone, dark grey, massive, lower part: limestone $\left(8723^{\prime}-8763^{\prime}\right) \quad$ conglomerate. (Kalksten, mørkegrå, massiv, nedre del med kalkstenskonglomerat).

$2671-2677 \mathrm{~m}$. C1-Limestone, interbedded with shale, vertical calcite veins;

$\left(8763^{\prime}-8782^{\prime}\right)$ lower part: sandstone, coarse grained, poorly sorted, grey, mostly quartz, some felspar. (Kalksten vekslende med lersten, med vertikale kalcitårer, nedre del: sandsten, grov, slet sorteret, hovedsagelig kvarts med noget feldspat).

2677 -2941 m. Lower Permian, Rotliegendes. $\left(8782^{\prime}-9649^{\prime}\right)$

$2677-2829 \mathrm{~m}$. Siltstone and sandstone, argillaceous, reddish to brown, $\left(8782^{\prime}-9283^{\prime}\right)$ increasing content of sand downwards. (Finsandsten og 
sandsten, leret, rødlig til mørkt rødbrun. Sandindhold tiltagende nedefter).

$2829-2863 \mathrm{~m}$. Conglomerate, subangular to rounded granules, pebbles, $\left(9283^{\prime}-9392^{\prime}\right)$ and small cobbles mostly of brown siltstone and claystone, grey, fine grained sandstones, and vein quartz. Matrix: sand, clay, reddish. (Konglomerat med kantede til afrundede korn og småblokke fortrinsvis af brun finsandsten og lersten, og af grå, finkornede sandsten med kvartsårer. Matriks af sand og ler, rødligt).

$2863-2941 \mathrm{~m}$. Extrusive igneous rock, dark grey to black, in part $\left(9392^{\prime}-9649^{\prime}\right)$ greenish. Groundmass very fine grained, small phenocrysts of felspar. Propylitized dacite at 2892 m. (9488').-(Eruptivbjergart, mørkegrå til sort, stedvis grønlig. Grundmasse meget finkornet med små feldspatstrøkorn. Propylitiseret dacit ved $2892 \mathrm{~m}$.

Well geologists: E.C.; J.F.F.; K.H.

Micropaleontologist: A.N.

Paleontologists: P.H.B.; T.S.

Lithology: T.S.; A.N.N.

Schlumberger interpreters: P.H.B.; J.F.F.; T.S.

Rödekro No. 1 - D.G.U. File No. 160.286.

Gravity anomaly: See Aabenraa No. 1. (file no. 160.101).

Seismic survey: Reflection. A local structure on a broad regional anticlinal feature, to the SW and S cut by an arched system of faults, to the NW by one or two faults. To the NE connection with another NW-SE trending anticline with closure against a NW-SE fault. The two anticlines are separated by a parallel syncline with a flat transversal gradient. The well is located on top of the southern structure on the upthrown side of a fault.

Previous core drill results: None.

Objective: Test of the Zechstein evaporite series for oil and gas accumulation.

Location: $6.5 \mathrm{~km}$. NW of Aabenraa City and $1.7 \mathrm{~km}$. N of Rödekro railway station. Coordinates: $55^{\circ} 05.139^{\prime} \mathrm{N} ; 3^{\circ} 14.245^{\prime} \mathrm{W}$ of Copenhagen Observatory. Drilling: Spudded December 5, 1958; completed December 30, 1958.

Elevation: Ground $49 \mathrm{~m}$. Rotary table $52.3 \mathrm{~m}$.

Stratigraphy, main lithology and paleontology:

0 - 102 m. Pleistocene. Glacial drift. (Istidsdannelser).

102 - 202 m. Miocene. Mica clay, brown, quartz sand and quartz gravel, grey. (Glimmerler, brunt, kvartssand og kvartsgrus, gråt). 
202 - 344 m. Eocene. Clay, grey, green, sticky. Basal parts red. (Ler, gråt og grønt, fedt, nederste del rødt). Vaginulinopsis decorata, Alabamina sp., Gaudryina hiltermanni.

344 - 391 m. Lower Eocene and Paleocene. Clay, dark grey, and shale, grey. (Ler, mørkegråt og lerskifer, grå). Anomalinoides grosserugosa, Epistomina scalaris, Trochammina inflata.

391 - 401 m. Danian. Bryozoan limestone, with chert. (Bryozokalk med flint). "Discorbis" binkhorsti, Gavelinopsis cf. involuta, Conorbina conula, Cibicides voltzianus, Osangularia lens, Pyramidina curvisutura.

401 - 545 m. Maastrichtian. Chalk, white, soft, with chert. (Skrivekridt med flint). Stensioeina pommerana, Bolivina incrassata, Bolivinoides draco draco, Gavelinella pertusa.

545 - 694 m. Campanian. Chalk, white, soft, with marl, grey. (Skrivekridt med grå mergel). Reussella pseudospinulosa, Gavelinella costata, Gyroidinoides sp.

694 - 791 m. Santonian. Limestone, white, chalky. (Kalksten, hvid, med bløde partier). Stensioeina exsculpta, Pseudovalvulineria cf. lorneiana, Gavelinella tumida, Globorotalites michelinianus.

791 - 855 m. Emscherian. Limestone, white, soft, with chert, light grey, whitish grey. (Kalksten, hvid, blød, med lysegrå og hvidgrå flint). Stensioeina praeexsculpta, Globotruncana cf. lapparenti, Gaudryina carinata, Globotruncana globigerinoides.

855 - $882 \mathrm{~m}$. Turonian. Marl, greyish white, beds of marl, greenish grey, (Mergel, grålighvid med lag af grønlig mergel). Gavelinella sp., Globorotalites $s p$.

882 - 899 m. Cenomanian. Marl, greenish grey. (Mergel, grønliggrå). Gavelinopsis cenomanica.

899 - 918 m. Albian. Claystone, clay, reddish brown, slightly calcareous. (Lersten og ler, rødligbrunt, svagt kalkholdigt). Gaudryina sp., Planulina sp., Gavelinella sp.

918 - 942 m. Aptian, Barremian, and ?Hauterivian. Claystone, greenish grey. Basal 5 m.: sand, yellowish grey, quartz, oolites. (Lersten, grønliggrå. Nederste $5 \mathrm{~m}$ : gulliggråt sand, kvarts, ooliter). Glomospira sp., Globorotalites sp., Lenticulina sp., Planularia crepidularis.

$942-1188$ m. Triassic, Keuper. Claystone, red, reddish brown, with claystone, green, greenish grey, traces of anhydrite. (Lersten, rød og rødligbrun, med lersten, grøn og grønliggrå og spor af anhydrit).

$1188-1313 \mathrm{~m}$. Muschelkalk. Claystone and siltstone, grey; anhydrite, and limestone, light grey, argillaceous. (Lersten og finsandsten, grå; anhydrit og kalksten, lysegrå, leret). 
$1313-1634$ m. Bunter. Claystone, reddish brown, some green parts. Locally beds of siltstone, reddish brown. (Lersten, rødligbrun med grønne partier. Stedvis lag af rødbrun finsandsten). Ditch sample: 1392-1402 m.: Chara oogoniae.

$1634-1645$ m. Pre-Zechstein. Igneous extrusive, greenish black, microcrystalline, dense, with quartz inclusions. (Eruptivbjergart, grønligsort, mikrokrystallinsk, tæt, med kvartsindeslutninger).

Well geologists: A.F.B.; L.B.R.

Micropaleontologist: A.B.

Schlumberger interpreters: A.F.B.; J.M.D.

Skagen No. 2 - D.G.U. File No. 1.43.

Gravity anomaly: No well defined expression of the feature evident on the residual gravity map. A gravity minimum trend suggested with negative gradient to the SE and the central part possibly in the Kattegat.

Location $\mathrm{N}$ of suggested central part of residual gravity minimum trend.

Seismic survey: a. Reflection. No reflection survey carried out.

b. Refraction. Refraction survey indicated a questionable low speed marker at about 700' (ca. $214 \mathrm{~m}$.) below well location.

Previous core drill results: The Skagen No. 1 core hole suggests top of prePleistocene at a depth of about 720' (ca. 219 m.) based upon ditch samples. First core taken at $825^{\prime}$ (ca. $251 \mathrm{~m}$.) supposed to be Wealden sand.

Objective: A stratigraphic test of the coal bearing beds of the Lower Cretaceous-Jurassic-Rhaetic sequence encountered by the Skagen No. 1 well.

Location: $1.6 \mathrm{~km}$. $\mathrm{N}$ to $\mathrm{E}$ of Skagen railway station. Coordinates: $57^{\circ} 44.22^{\prime} \mathrm{N}$; $1^{\circ} 58.54^{\prime} \mathrm{W}$ of Copenhagen Observatory.

Drilling: Spudded September 24, 1951; completed October 25, 1951.

Elevation: Ground $1.8 \mathrm{~m}$. (6 $\left.6^{\prime}\right)$. Rotary table $2.2 \mathrm{~m}$. $\left(7^{\prime}\right)$.

\section{Stratigraphy, main lithology and paleontology:}

$0-214 \mathrm{~m}$. Pleistocene. Marine beds of clay and sand, and glacial drift.

$\left(0^{\prime}-703^{\prime}\right) \quad$ (Marine lag af ler og sand samt glacigene istidsdannelser).

214 - 326 m. Lower Cretaceous.

$\left(703^{\prime}-1070^{\prime}\right)$

$214-304 \mathrm{~m}$. Silt and silty clay, dark greenish grey, dark brown, coal$\left(703^{\prime}-997^{\prime}\right)$ beds of $1 \mathrm{~cm}$. thickness. (Finsand og finsandet ler, mørkt grønliggråt og mørkebrunt med centimetertykke kullag).

$304-308 \mathrm{~m}$. Clay, grey, sticky, concretionary clay ironstone, gravel at $\left(997^{\prime}-1009^{\prime}\right)$ base. (Ler, gråt, fedt, med lerjernstenskonkretioner. Nederst: grus). 
$308-326 \mathrm{~m}$. Silt and silty clay, dark grey, at $321 \mathrm{~m}$.: coal bed $1 \mathrm{~m}$.

$\left(1009^{\prime}-1070^{\prime}\right) \quad$ thick. (Finsandsten og finsandet ler, mørkegråt, ved $321 \mathrm{~m}$ et kullag af een meters tykkelse).

326 - 406 m. Upper Jurassic, Malm. Silt and silty clay, interbedded, greenish $\left(1070^{\prime}-1333^{\prime}\right)$ grey. (Finsand og finsandet ler, afvekslende, grønliggråt). Shell fragments.

406 - 473 m. Middle Jurassic, Dogger. Sand, silt and clay, interbedded, grey $\left(1333^{\prime}-1553^{\prime}\right)$ to dark grey, coal beds, up to $6 \mathrm{~cm}$. thickness. (Sand, finsand og ler, afvekslende, gråt til mørkegråt med kullag af indtil $6 \mathrm{~cm}$ tykkelse).

473 - 553 m. Lower Jurassic.

$\left(1553^{\prime}-1814^{\prime}\right)$

473 - 547 m. Lias (middle?). Clay, light greenish grey, grey, tough, beds

$\left(1553^{\prime}-1794^{\prime}\right)$ of sand and concretionary clay ironstone. (Ler, lyst grønliggråt, gråt, sejgt med lag af sand og lerjernstenskonkretioner). Bolivina liasica abundant, Nodosaria spp., Geinitzina tenera.

547 - $553 \mathrm{~m}$. Lias alpha 3. Clay, silty, and silt, dark greenish grey, (1794'-1814') limestone $7 \mathrm{~cm}$. argillaceous, grey. (Ler, finsandet og finsand, mørkt grønliggråt med $7 \mathrm{~cm}$ kalksten, leret, grå). Oxytoma sinemuriensis, Belemnites sp.

553 - $564 \mathrm{~m}$. Rhaetic. Clay and silt, greenish grey, lignite. (Ler og finsand, $\left(1814^{\prime}-1852^{\prime}\right)$ grønliggråt, med lignit). Shell fragments.

564 - 593 m. Triassic, Keuper. Clay, green, tough; yellow, orange, yellowish $\left(1852^{\prime}-1944^{\prime}\right)$ brown parts. (Ler, grønt, sejgt, gult og orange med gulligbrune partier).

$593-620 \mathrm{~m}$. Triassic or ?Permian, Arkose, argillaceous; chunks of base(1944'-2035') ment. (Arkose, leret, med brudstykker af grundfjeld).

Well geologists: J.F.F.; M.H.; O.B.; G.V.O.

Micropaleontologist: A.N.

Schlumberger interpreter: J.A.N.; T.S.

\section{Slagelse No. 1 - D.G.U. File No. 215.257.}

Gravity anomaly: About $6 \mathrm{~km}$. NNW of the centre of residual gravity minimum "AT" with a negative relief of about 3 mgal.

Seismic survey: Reflection. A reflection horizon in the Triassic suggests an intensely faulted block-structure with a minimum fault-closure of about $60 \mathrm{~m}$. on the upthrown side of a fault system $\mathrm{S}$ of the well.

Previous core drill results: None.

Objective: To test suggested fault closure for oil and gas accumulation in the Zechstein. 
Location: $4.4 \mathrm{~km}$. SSE of Slagelse City and $700 \mathrm{~m}$. N of Harrested village. Coordinates: $55^{\circ} 22.364^{\prime} \mathrm{N}$; $1^{\circ} 11.978^{\prime} \mathrm{W}$ of Copenhagen Observatory.

Drilling: Spudded March 9, 1959; completed May 21, 1959.

Elevation: Ground $37.6 \mathrm{~m}$. Rotary table $40.9 \mathrm{~m}$.

Stratigraphy, main lithology and paleontology:

0 - 102 m. Pleistocene. Glacial drift, clay, sand and gravel. (Istidsdannelser, ler, sand og grus).

12 - 17 m. Marine interglacial. Clay, grey, silty. (Ler, gråt, finsandet). Elphidium clavatum, Nonian depressulus, Cassidulina laevigata, Streblus beccarii.

77 - 92 m. Eocene. (dislocated). Clay, greenish grey, sticky. (Ler, grønliggråt, fedt. Eocæn flage). Globigerina yeguaensis, Anomalinoides grosserugosa, Alabamina sp., Cibicides sulzensis.

92 - 102 m. Glacial drift. Sand, coarse grained, gravel and pebbles. (Sand, groft, grus og småsten. Istidsdannelser).

102 - 262 m. Paleocene. Marl, light grey, with marlstone, dark grey. (Mergel, lysegrå og mørkegrå mergelsten). Nodosaria torsicostata, Bulimina trigonalis.

262 - 313 m. Danian. Bryozoan limestone with chert, and chalk, white, soft. (Bryozokalk og slamkalk med flint). Osangularia lens, Cibicides voltzianus, Gavelinella bullata.

313 - 608 m. Maastrichtian-Campanian. Chalk, white, soft, chert; limestone, white, soft. (Skrivekridt og flint og hvid, blød kalksten). Bolivina incrassata, Stensioeina pommerana, Gavelinella pertusa, Marssonella oxycona, Buliminella laevis, Gavelinella costata, Reussella pseudospinulosa.

608 - 935 m. Santonian-Coniacian. Limestone, white, soft, with beds of marl, grey, limestone, greyish white, argillaceous, harder towards base. (Kalksten, hvid, blød, med lag af grå mergel og grålighvid kalksten, leret, forneden hård). Stensioeina exsculpta, Stensioeina praeexsculpta, Globotruncana spp.

935 - 949 m. ?Turonian. Limestone, greyish white. (Kalksten, grålig hvid). Globotruncana spp.

949 - 962 m. Albian-?Aptian. Claystone, yellowish-reddish brown, calcareous. (Lersten, gullig og rødlig brun, kalkholdig). Planulina sp., Gavelinella sp., Arenobulimina sp., Tritaxia sp.

962 - 971 m. Lower Cretaceous. Claystone, greyish green, with oolites, brown. (Lersten, gråliggrøn, med brune ooliter). Hedbergella sp., Fish teeth. 
$971-1169$ m. Lower Jurassic, Lias.

971 - 997 m. Claystone bluish, grey, calcareous. (Lersten, blågrå, kalkholdig).

$997-1022$ m. Shale, dark grey, slightly calcareous. (Lersten, mørkegrå, svagt kalkholdig). Planularia inaequistriata, Planularia stilla, Dentalina matutina.

$1022-1169 \mathrm{~m}$. Claystone, dark grey, calcareous, and shale, grey, beds of siltstone, light greenish grey. (Lersten, mørkegrå og grå, kalkholdig med lag af finsandsten, lys grønliggrå).

$1169-1332 \mathrm{~m}$. Rhaetic. Shale, grey, greenish grey, thin beds of siltstone and lignite. Oolites. (Lersten, grå og grønliggrå med tynde lag af finsandsten og lignit). Teeth, Ostracods.

$1332-1652 \mathrm{~m}$. Keuper. Claystone and shale, variegated, anhydritic at base. (Lersten, broget, nederst med anhydrit).

$1652-1760 \mathrm{~m}$. Muschelkalk. Claystone, light grey, calcareous, and limestone, greenish grey, argillaceous. (Lersten, lysegrå, kalkholdig og kalksten, grønliggrå, leret).

$1760-2254 \mathrm{~m}$. Bunter. Claystone and shale, reddish brown, locally grey, greyish green, and siltstone, light reddish brown. (Lersten, rødligbrun, stedvis grå og grågrøn, og finsandsten, lys rødligbrun). Chara oogoniae.

$2254-2583$ m. Upper Permian, Zechstein.

$2254-2287$ m. A8-Anhydrite, greyish white. (Anhydrit, grålighvid).

$2287-2403$ m. A5-Rock salt? semi-translucent. (Stensalt, halvtgennemskinneligt).

2403 -2423 m. A4-Anhydrite? greyish white, dolomite, brownish grey. (Anhydrit, grålighvid og dolomit, brunliggrå).

$2423 \mathrm{~m}$. Boulders of shale, dark grey; igneous rock, brownish red, slight scoreaceous texture, and shale, brown. (Blokke af lersten, mørkegrå, af brunligrød eruptiv, let slagget tekstur, og brun lersten).

2423 -2433 m. B4-Anhydrite, greyish white, and dolomite, grey, argillaceous, pale oil cut, faint petroleum odeur. (Anhydrit, grålighvid, og dolomit, grå, leret, svag oliereaktion og svag olielugt).

$2433-2439$ m. B3-Dolomite, buff, hard, in lower part interlaminated argillaceous material, dark grey. Several slickensides, basal $1 \mathrm{~m}$. badly fractured; dip on contact $28^{\circ}$. (Dolomit, brunliggul, hård, i nedre del med tynde lag af leret dolomit, mørkegrå. Talrige glideflader. Nederste $1 \mathrm{~m}$ stærkt opsprækket. Kontaktfladens hældning $28^{\circ}$ ).

$2439-2576$ m. C5-Rock salt, white to pinkish, semi-translucent, trace of 
anhydrite. (Stensalt, hvidt til lyst rødligt, halvgennemskinneligt med spor af anhydrit).

2576-2583 m. C4-Anhydrite, greyish white, beds of dolomite. Dip $9^{\circ}$ (Anhydrit, grålighvid med lag af dolomit; laghældning $9^{\circ}$ ).

$2583-2917 \mathrm{~m}$. Ordovician-Silurian.

$2583-2626 \mathrm{~m}$. Limestone, grey, and shale, dark grey, thinly laminated. Dip 6-7 $7^{\circ}$ (Kalksten, grå og tynde lag af lerskifer, mørkegrå; laghældning $\left.6-7^{\circ}\right)$. Graptolithes.

$2626-2637 \mathrm{~m}$. Claystone, dark red, silty, non calcareous. (Lersten, mørkerød, finsandet, kalkfri).

$2637-2917 \mathrm{~m}$. Shale, dark grey, beds of siltstone, light grey. Dip $16^{\circ}$ ?$24^{\circ}-30^{\circ}-40^{\circ}$. (Lerskifer, mørkegrå med lag af finsandsten, lysegrå. Laghældninger $16^{\circ}$ ? $-24^{\circ}-30^{\circ}-40^{\circ}$ ). $2768-2774 \mathrm{~m}$ : Dictyonema sp., 2810-2812 m: Monograptus crispus LAPWORTH.

2917 -2944 m. Cambrian. Shale, black, pyritic, with spindle-shaped Baryte crystals, "Alum shale". Dip 10-12 . (Lerskifer, sort, pyritisk, med tenformede tungspatkrystaller, "Alunskifer". Laghældning $10-12^{\circ}$ ).

2944 -2966 m. Shale, dark grey, hard. Dip 20․ (Lerskifer, mørkegrå, hård. Laghældning $20^{\circ}$ ).

2966 -2972 m. Lower Cambrian or Eocambrian. Sandstone, quartzitic, light grey. Dip $22^{\circ}$ ? (Sandsten, kvartsitisk, lysegrå; laghældning $22^{\circ}$ ?).

Well geologists: A.F.B.; E.S.; L.B.R.; G.L.

Micropaleontologist: A.B.

Paleontologist: L.B.R.

Schlumberger interpreters: A.F.B.; J.M.D.

Tönder No. 1 - D.G.U. File No. 166.230.

Gravity anomaly: No well defined expression of the feature evident on the residual gravity map except that there is a gravity nose a little off set to the north.

Seismic survey: Reflection. Excellent results were obtained and two horizons mapped, one at 2800' (ca. $850 \mathrm{~m}$.) over the crest and the other at 7600' (ca. $2320 \mathrm{~m}$.). Indicated minimum closure on the shallower horizon amounts to $400^{\prime}$ (ca. $122 \mathrm{~m}$.) and on the deeper horizon to $800^{\prime}$ (ca. $244 \mathrm{~m}$.). Flattening of the relief below 10.000' (ca. $3048 \mathrm{~m}$.) indicated on some of the profiles.

Previous core drill results: Five holes drilled on the Tönder structure carried to the top of the Danian. Closure was less at the shallower depth, but it was 
possible to estimate the top of the Danian within a few feet in advance of drilling. Absence of the Oligocene over the structure.

Location: About $3 \mathrm{~km}$. N to W of Tönder Central station and $1 \mathrm{~km}$. W of Highway No. 11 (Tönder-Ribe). Coordinates: $54^{\circ} 57.62^{\prime} \mathrm{N} ; 3^{\circ} 43.38^{\prime} \mathrm{W}$ of Copenhagen Observatory.

Drilling: Spudded May 5, 1951; completed June 19, 1952.

Elevation: Ground 7.9 m. (26'). Rotary table 13.4 m. (44').

Stratigraphy, main lithology and paleontology:

0 - $46 \mathrm{~m}$. Pleistocene. Sand and clay. (Sand og ler).

$\left(0-152^{\prime}\right)$

46 - $251 \mathrm{~m}$. Miocene. Mica sand, grey, fine grained, mica clay, brown, silty.

$\left(152^{\prime}-822^{\prime}\right) \quad$ (Glimmersand, gråt, fint og glimmerler, brunt, finsandet).

251 - 379 m. Eocene.

$\left(822^{\prime}-1242^{\prime}\right)$

251 - 293 m. Clay, greyish green, sticky. (Ler, gråliggrønt, fedt).

$\left(822^{\prime}-962 '\right)$ Vaginulinopsis decorata, Cibicides sulzensis.

293 - 372 m. Clay, green, sticky. (Grønt plastisk ler). Radiolaria abun$\left(962^{\prime}-1222^{\prime}\right)$ dant.

372 - 379 m. Clay, brown, sticky. (Brunt plastisk ler). Gaudryina hilter(1222'-1242') manni, Vaginulinopsis decorata.

379 - 417 m. Lower Eocene and Paleocene. Clay, grey, sticky. (Gråt fedt ler). $\left(1242^{\prime}-1368^{\prime}\right)$

417 - 421 m. Danian. Bryozoan limestone with yellowish chert. (Bryozokalk $\left(1368^{\prime}-1382^{\prime}\right)$ med gullig flint).

421 - 897 m. Upper Cretaceous. Chalk, white, soft, with chert, downwards

$\left(1382^{\prime}-2942^{\prime}\right)$ interbedded marl, greenish white. (Skrivekridt, med flint, nedefter vekslende med grønlighvid mergel). Stensioeina pommerana, Angulogavelinella bettenstaedti, Reussella pseudospinulosa, Globorotalites michelinianus, Pseudovalvulineria of. lorneiana, Stensioeina exsculpta.

897 - 960 m. Lower Cretaceous. Clay, reddish brown, soft, highly calcareous; $\left(2942^{\prime}-3151^{\prime}\right)$ downwards: claystone, dark grey, greenish grey, silty; at base: sand, fine grained, greenish and yellowish grey, interbedded with shale and claystone, black, greyish black. (Ler, rødbrunt, blødt, kalkrigt; nedefter: lersten, mørkegrå til grønliggrå, finsandet. Nederst: sand, fint, grønliggråt og gulliggråt, vekslende med lersten, sort til gråsort). Gavelinella $s p$.

$960-1262 \mathrm{~m}$. Keuper. Claystone and clay, varicoloured, brown, green, $\left(3151^{\prime}-4142^{\prime}\right)$ locally interbedded with sand, fine grained, brownish, grey; anhydrite. (Lersten og ler, broget, brunt og grønt, stedvis vekslende med sand, fint, brunligt til gråt med anhydrit). 
$1262-1431 \mathrm{~m}$. Muschelkalk. Claystone, beds of limestone and sand, fine $\left(4142^{\prime}-4695^{\prime}\right)$ grained. Section is greenish grey, grey, brown, locally varicoloured. (Lersten med lag af kalksten og fint sand. Serien er grønliggrå, grå, brun og stedvis broget).

$1431-2148$ m. Bunter.

$\left(4695^{\prime}-7047^{\prime}\right)$

$1431-1544$ m. Röt. Claystone greenish brown, with lumps of anhydrite;

$\left(4695^{\prime}-5066^{\prime}\right)$ with rock salt near the base. (Lersten, grønligbrun, med anhydritknolde og nederst med stensalt).

$1544-1558$ m. Röt. Claystone, silty, grey, greenish grey, calcareous, with

$\left(5066^{\prime}-5112^{\prime}\right)$ anhydrite. (Lersten, finsandet, grå og grønliggrå, kalkholdig, med anhydrit).

$1558-1605$ m. Röt. Rock salt, clear to faint orange, with beds of anhy-

$\left(5112^{\prime}-5265^{\prime}\right)$ drite. (Stensalt, klart til svagt orangefarvet med lag af anhydrit).

$1605-1650 \mathrm{~m}$. Claystone, greenish grey, reddish brown, with anhydrite.

$\left(5265^{\prime}-5412^{\prime}\right) \quad$ (Lersten, grønliggrå og rødligbrun, med anhydrit).

1650-1681 m. Sandstone, argillaceous, interbedded with claystone,

$\left(5412^{\prime}-5514^{\prime}\right)$ reddish brown, with anhydrite. (Sandsten, leret, afvekslende med lersten, rødligbrun, med anhydrit).

$1681-1783 \mathrm{~m}$. Claystone, reddish brown with greenish spots, with an-

$\left(5514^{\prime}-5849^{\prime}\right)$ hydrite. (Lersten, rødligbrun med grønlige partier, med anhydrit).

$1783-1816 \mathrm{~m}$. Sandstone, argillaceous, reddish brown, soft, calcareous.

$\left(5849^{\prime}-5959^{\prime}\right) \quad$ (Sandsten, leret, rødligbrun, blød, kalkholdig).

$1816-2148 \mathrm{~m}$. Claystone, reddish brown, with green spots, with anhy-

$\left(5959^{\prime}-7047^{\prime}\right)$ drite. (Lersten, rødligbrun med grønne pletter, med anhydrit).

2148 -3118 m. Upper Permian, Zechstein.

$\left(7047^{\prime}-10230^{\prime}\right)$

$2148-2154$ m. A8-Anhydrite, white, finely crystalline. (Anhydrit, hvid,

$\left(7047^{\prime}-7067^{\prime}\right)$ finkrystallinsk).

2154-2159 m. ?A6-Potassium zone (probably zone of brine flow with

$\left(7067^{\prime}-7082^{\prime}\right)$ potassium). (?Kalizone (sandsynligvis zone for indbrud af kaliholdig saltopløsning)).

$2159-2239$ m. A5-Rock salt, greyish pink, faint orange, milky white, $\left(7082^{\prime}-7346^{\prime}\right)$ seams of anhydrite. (Stensalt, gråligt lyst rødt til svagt orange, halvgennemsigtigt hvidt, med striber af anhydrit).

2239 -2259 m. A4-Anhydrite, grey, yellowish grey, dolomitic, with in-

$\left(7346^{\prime}-7413^{\prime}\right)$ clusions of rock salt. (Anhydrit, grå, gulliggrå, dolomitisk, med indeslutninger af stensalt).

2259 -2260 m. A3-dolomite, ca. $30 \mathrm{~cm}$., greyish brown, micro crystalline.

(7413'-7414') (ca. $30 \mathrm{~cm}$ dolomit, gråligbrun, mikrokrystallinsk). 
$2260-2377$ m. B5-Rock salt, orange, finely to coarsely crystalline, ir$\left(7414^{\prime}-7797^{\prime}\right)$ regular laminae of anhydrite. (Stensalt, fin- til grovkrystallinsk med tynde uregelmæssige lag af anhydrit).

$2377-2395 \mathrm{~m}$. B4-Anhydrite, dolomitic, yellowish brown, locally inter$\left(7797^{\prime}-7856^{\prime}\right)$ bedded with dolomite. (Anhydrit, dolomitisk, gulligbrun, anhydrit og dolomit stedvis vekslende i tynde lag).

2395-2401 m. B3-Dolomite, brownish grey, knots of anhydrite, very $\left(7856^{\prime}-7876^{\prime}\right)$ light stain of oil. (Dolomit, brunliggrå, med små anhydritknolde. Enkelte pletter af råolie).

$2401-2402$ m. B1-Salt clay, anhydrite, whitish, dark grey, interbedded $\left(7876^{\prime}-7879^{\prime}\right)$ with grey clay. (Saltler, hvidlig til mørkegrå anhydrit vekslende med gråt ler).

2402-2428 m. C7-Rock salt, faint orange, greyish, thin laminae of an$\left(7879^{\prime}-7967^{\prime}\right)$ hydrite. (Stensalt, svagt orange til gråligt med tynde lag af anhydrit).

2428 -2477 m. C6-Potassium zone. Rock salt, faint orange, finely lam$\left(7967^{\prime}-8127^{\prime}\right)$ inated with lines and seams of polyhalite. (Kalizone. Stensalt, svagt orange med striber og tynde bånd af polyhalit).

2477 -3088 m. C5-Rock salt, clear, milky white, greyish, brownish. Very $\left(8127^{\prime}-10130^{\prime}\right)$ irregular bedding about $2850 \mathrm{~m}$. (9350'). (Stensalt, klart til halv gennemskinneligt hvidt, gråligt og brunligt. Meget uregelmæssig lagdeling omkring $2850 \mathrm{~m}$ ).

3088 -3091 m. C4-Anhydrite, light grey, slightly dolomitic, veins and $\left(10130^{\prime}-10142^{\prime}\right)$ seams of salt. (Anhydrit, lysegrå, svagt dolomitisk med årer og bånd af stensalt).

$3091-3118 \mathrm{~m}$. C3-Dolomite, greyish brown, seams and inclusions of salt $\left(10142^{\prime}-10230^{\prime}\right)$ and anhydrite. Oil stained. (Dolomit, gråbrun med bånd og indeslutninger af stensalt og anhydrit. Plettet af råolie).

Well geologists: E.C.; M.H.; G.L.; P.H.B.; L.B.R.; A.B. Micropaleontologist: A.N.

Paleontologist: R.W.

Lithology: W.S.; W.C.; T.S.

Schlumberger interpreters: J.A.N.; T.S.

\section{Tönder No. 2 - D.G.U. File No. 166.232.}

Gravity anomaly: Gravity nose south of a residual minimum trend. The minimum trends NW-SE suggesting a downfaulted graben zone north of the Tönder area.

Seismic survey: Reflection. The extended and revised seismic reflection work suggested the Tönder structure to be a sort of a salt anticline bounded 
by a fault to the north. The salt sequence of the Zechstein very much reduced along the fault probably due to salt flowage. The C3-Dolomite dipping SW situated about 500' (ca. $152 \mathrm{~m}$.) structurally higher than at Tönder No. 1. Previous core drill results: See Tönder No. 1.

Objective: A test of the Zechstein.

Location: $6 \mathrm{~km}$. N of Tönder Central station and $600 \mathrm{~m}$. N of Abild church at western side of Highway No. 11 (Tönder-Ribe). Coordinates: $54^{\circ} 59.12^{\prime} \mathrm{N}$; $3^{\circ} 43.04^{\prime} \mathrm{W}$ of Copenhagen Observatory.

Drilling: Spudded July 10, 1952; completed March 7, 1953.

Elevation: Ground 12.5 m. (41'). Rotary table 17.4 m. (57').

Stratigraphy, main lithology and paleontology:

0 - $47 \mathrm{~m}$. Pleistocene. Sand and glacial drift. (Sand og istidsdannelser).

$\left(0^{\prime}-154^{\prime}\right)$

$47-297 \mathrm{~m}$. Miocene. Clay, silty, greyish brown, greenish brown; mica $\left(154^{\prime}-974^{\prime}\right)$ clay, greyish brown and dark brown, a bed of fossiliferous quartz-gravel. (Ler, finsandet, gråbrunt og grønligbrunt, glimmerler, gråbrunt og mørkebrunt med lag af fossilførende kvartsgrus). Streblus beccarii, Nonion soldanii, Bulimina elongata, Uvigerina hosiusi, Cancris auriculus, Ceratocancris haueri, Ceratobulimina contraria, Epistomina elegans, Asterigerina staeschei.

297 - 436 m. Eocene. Clay, sticky, greyish green; basal 3 m. reddish brown. $\left(974^{\prime}-1429^{\prime}\right) \quad$ (Ler, fedt, grågrønt. Nederste 3 m rødbrunt). Vaginulinopsis decorata, Globigerina spp., Eponides candidulus, Radiolaria, Gaudryina hiltermanni.

436 - 469 m. Paleocene and Lower Eocene. Clay, dark grey, tuff beds in $\left(1429^{\prime}-1539^{\prime}\right)$ upper part. Below $464 \mathrm{~m}$.: Claystone, dark grey, seams of sandstone, slightly glauconitic. (Ler, mørkegråt med lag af vulkansk aske i øvre del. Fra $464 \mathrm{~m}$ : Lersten, mørkegrå, med bånd af sandsten, svagt glaukonitholdig).

469 - 478 m. Danian. Bryozoan limestone, white, soft. (Bryozokalk, hvid, (1539'-1567') blød). "Discorbis" binkhorsti, Pyramidina curvisuturata.

478 - 964 m. Senonian-Turonian. Chalk, white, soft, downwards harder, with $\left(1567^{\prime}-3164^{\prime}\right)$ greenish marl. (Skrivekridt, nedefter kalksten, hvid, med grønlig mergel). Stensioeina pommerana, Angulogavelinella bettenstaedti, Pseudovalvulineria cf. lorneiana, Globorotalites michelinianus, Stensioeina exsculpta.

964 - 986 m. Cenomanian. Limestone, white, with greenish marl. (Kalksten, (3164'-3234') hvid, med grønlig mergel). Gavelinopsis cenomanica.

986 - 996 m. Albian. Clay, reddish brown, yellowish brown. (Ler, rødbrunt $\left(3234^{\prime}-3269^{\prime}\right) \quad$ og gulbrunt). Arenobulimina sp., Gavelinella sp. 
996-1082 m. Lower Cretaceous. Clay, dark grey, greenish grey; at base: $\left(3269^{\prime}-3550^{\prime}\right)$ sand, sandy clay and shale, dark grey, interbedded. (Ler, mørkegråt, grønliggråt, nederst vekslende lag af sand, sandet ler og lersten, mørkegrå). Planularia crepidularis.

$1082-1161 \mathrm{~m}$. Rhaetic. Siltstone and sand, fine grained, interbedded with $\left(3550^{\prime}-3809^{\prime}\right)$ claystone, silty, dark grey. Lower part: shale, limestone, claystone, interbedded, grey. (Finsandsten og fint sand, vekslende med lag af finsandet lersten, mørkegrå. Nederste del: vekslende lersten og kalksten, grå). Ostracods abundant.

$1161-1593$ m. Keuper. Claystone, varicoloured, light grey, brown, greenish $\left(3809^{\prime}-5228^{\prime}\right)$ grey; anhydrite, beds of sandstone, silty, greenish grey, light brownish. (Lersten, broget, lysegrå, brunt, grønliggråt; anhydrit og sandstenslag, finsandet, grønliggrå og lys brunlig).

$1593-1760 \mathrm{~m}$. Muschelkalk. Claystone and limestone, interbedded with thin $\left(5228^{\prime}-5774^{\prime}\right)$ beds of sand, varicoloured, grey, green, brown. (Lersten og kalksten, afvekslende med tynde lag af sand, broget, gråt, grønt og brunt).

$1760-2428 \mathrm{~m}$. Bunter.

$\left(5774^{\prime}-7967^{\prime}\right)$

1760-1867 m. Röt. Claystone, chocolate brown to dark brown, with

$\left(5774^{\prime}-6124^{\prime}\right)$ anhydrite. Possibly with crystals of rock salt. (Lersten, brun til mørkebrun, med anhydrit. Muligvis med krystaller af stensalt).

$1867-1927$ m. Röt. Claystone, dark brown and greenish grey, interbedded $\left(6124^{\prime}-6321^{\prime}\right)$ with laminated anhydrite and rock salt. (Lersten, mørkebrun og grønliggrå, vekslende med tynde lag af anhydrit og stensalt).

1927 -1973 m. Röt. Claystone, silty and sandy, reddish brown with green $\left(6321^{\prime}-6474^{\prime}\right)$ beds, calcareous, anhydritic, with crystals of rock salt. (Lersten, finsandet og sandet, rødligbrun med grønne lag, kalkholdig, anhydritisk med krystaller af stensalt). Chara oogoniae.

$1973-1995$ m. Röt. Claystone, silty, interbedded with sandstone, reddish $\left(6474^{\prime}-6544^{\prime}\right)$ brown with green portions, with rock salt. (Lersten, finsandet, vekslende med sandsten, rødbrun med grønne partier, med stensalt).

1995 -2004 m. Röt. Limestone, crystalline, dolomitic, greenish grey, inter$\left(6544^{\prime}-6574^{\prime}\right)$ bedded with claystone, reddish brown and green. (Kalksten, krystallinsk, dolomitisk, grønliggrå, vekslende med lersten, rødligbrun og grøn).

2004-2077 m. Claystone, silty and sandy, reddish brown with green $\left(6574^{\prime}-6814^{\prime}\right)$ portions, calcareous and dolomitic. Oolites. (Lersten, fin- 
sandet og sandet, rødbrun og med grønne partier, kalkholdig og dolomitisk).

$2077-2113 \mathrm{~m}$. Sand and argillaceous sand, reddish brown, with anhydrite. $\left(6814^{\prime}-6932^{\prime}\right) \quad$ (Sand og leret sand, rødligbrunt, med anhydrit).

$2113-2428 \mathrm{~m}$. Claystone, occasionally silty, reddish brown with green $\left(6932^{\prime}-7967^{\prime}\right)$ portions, with nodular anhydrite. (Lersten, stedvis finsandet, rødbrunt med grønne partier, med anhydritknolde).

\section{8 -3083 m. Upper Permian, Zechstein.}

$\left(7967^{\prime}-10115^{\prime}\right)$

2428-2432 m. A8-Anhydrite, salt clay, dark brown, green parts. (Anhy$\left(7967^{\prime}-7978^{\prime}\right)$ drit, saltler, mørkebrunt med grønne partier).

2432-2511 m. A5-Rock salt, clear, colourless to pink; top: with salt clay, $\left(7978^{\prime}-8238^{\prime}\right)$ downwards with beds of anhydrite. (Stensalt, klart, farveløst til lyst rødigt, øverst med saltler, nedefter med lag af anhydrit).

2511 -2527 m. A4-Anhydrite, white, slightly dolomitic, inclusions of salt. $\left(8238^{\prime}-8291^{\prime}\right) \quad$ Blow out of non-inflammable gas. (Anhydrit, hvid, svagt dolomitisk med indeslutninger af salt. Udbrud af ikkebrændbar luftart).

2527-2655 m. B5-Rock salt, clear, colourless, faintly pink, anhydrite $\left(8291^{\prime}-8711^{\prime}\right)$ irregular seams. (Stensalt, klart, farveløst, svagt rødligt, uregelmæssige bånd af anhydrit).

2655-2669 m. B4-Anhydrite, dolomitic, greyish white and dolomite, grey$\left(8711^{\prime}-8755^{\prime}\right)$ ish brown. Very light yellowish oil cut. (Anhydrit, dolomitisk, grålighvid, og dolomit, gråligbrun. Meget lys gullig oliereaktion).

2669-2674 m. B3-Dolomite and B1-Shale, brownish grey, dense, down$\left(8755^{\prime}-8773^{\prime}\right)$ wards interbedded with anhydrite and black shale. (Dolomit, brunlig-grå, tæt, nedefter vekslende med anhydrit og sort lerskifer).

2674-2749 m. C7-Rock salt, colourless, faint orange, top part with seams $\left(8773^{\prime}-9018^{\prime}\right)$ and knots of anhydrite. (Stensalt, farveløst, svagt orange, øverst med bånd og knolde af anhydrit).

$2749-2778$ m. C6-Rock salt, veins of potassium minerals. (Stensalt, med (9018'-9113') årer af kalimineraler).

2778-2991 m. C5-Rock salt, colourless, faint orange, downwards laminae $\left(9113^{\prime}-9812^{\prime}\right)$ and streaks of anhydrite. (Stensalt, farveløst, svagt orange, nedefter tynde lag og striber af anhydrit).

2991-2994 m. C4-Anhydrite, slightly dolomitic, with gas. (Anhydrit, (9812'-9822') svagt dolomitisk med gas).

2994-3019 m. C3-Dolomite, and dolomitic limestone, greyish brown, $\left(9822^{\prime}-9905^{\prime}\right)$ dense, finely laminated, interbedded. Locally oil stained. 
(Dolomit og dolomitisk kalksten, gråligbrun, tæt, i skiftende tynde lag. Stedvis pletter af råolie).

3019 -3022 m. C2-Limestone. (Kalksten).

$\left(9905^{\prime}-9915^{\prime}\right)$

3022 -3024 m. D9-Dolomite, scattered inclusions of rock salt and anhy-

$\left(9915^{\prime}-9922^{\prime}\right)$ drite. (Dolomit med spredte indeslutninger af stensalt og anhydrit).

3024-3051 m. D4-Anhydrite, laminated, locally massive. (Anhydrit i $\left(9922^{\prime}-10010^{\prime}\right)$ tynde lag, stedvis massivt).

3051 -3055 m. D2-Limestone, in top transition to D4-anhydrite. (Kalk$\left(10010^{\prime}-10024^{\prime}\right)$ sten, øverst med overgang til D4-anhydrit).

3055 -3056 m. E9-Dolomite, about $30 \mathrm{~cm}$. (ca. $30 \mathrm{~cm}$ dolomit).

$\left(10024^{\prime}-10025^{\prime}\right)$

3056 -3061 m. E4-Anhydrite, greyish white, pinkish white, dolomitic. (An-

(10025'-10043') hydrit, grålighvid, rødlighvid, dolomitisk).

3061-3064 m. E3-Dolomite, greyish brown, pinkish brown, dense, and (10043'-10054') anhydrite interlaminated. (Dolomit, gråbrun og rødligbrun, tæt, vekslende med tynde lag af anhydrit).

3064-3083 m. E2 +3-Limestone and dolomite, greyish brown, reddish (10054'-10114') brown. (Kalksten og dolomit, gråligbrun og rødligbrun). At $3083 \mathrm{~m}$. E1-Siltstone, about $30 \mathrm{~cm}$., sandy, grey, greyish black.

$\left(10114^{\prime}-10115^{\prime}\right) \quad$ (ca. $30 \mathrm{~cm}$ finsandsten, sandet, grå og gråsort).

3083 -3196 m. Lower Permian, Rotliegendes. Siltstone, sandy, argillaceous, $\left(10115^{\prime}-10484^{\prime}\right)$ reddish brown. (Finsandsten, sandet og leret, rødbrun).

Well geologists: E.C.; M.H.; L.B.R.; G.L.

Micropaleontologist: A.N.

Paleontologist: P.H.B.

Lithology: P.H.B.; T.S.

Schlumberger interpreters: J.A.N.; T.S.

Uglev No. 1 - D.G.U. File No. 44.141.

Gravity anomaly: Located in the centre of residual gravity minimum " $G$ " classified as the expression of a shallow to moderately deep piercement salt dome.

Seismic survey: a. Reflection. E-W profile across the dome. Top of dome material suggested at about $2700^{\prime}$ (ca. $823 \mathrm{~m}$.) subsea at the location (ca. $2800^{\prime}=$ ca. $853 \mathrm{~m}$. depth).

b. Refraction. N-S line suggests the dome material at about $2700^{\prime}$ (ca. $823 \mathrm{~m}$.) subsea $\left(2800^{\prime}=853 \mathrm{~m}\right.$. depth). 
Previous core drill results: The well Hvidbjerg No. 1 drilled about $115 \mathrm{~m}$. north of Uglev No. 1 encountered Lower Cretaceous clay at final depth of $2249^{\prime}$ (ca. 686 m.).

Objective: Designed to test the sedimentary section above the cap rock for oil and gas and to test the salt section for the possible occurrence of potash minerals.

Location: About $32 \mathrm{~km}$. S of Thisted City and $2.8 \mathrm{~km}$. S of Hvidbjerg railway station. Coordinates: $56^{\circ} 37.58^{\prime} \mathrm{N} ; 4^{\circ} 02.52^{\prime} \mathrm{W}$ of Copenhagen Observatory.

Drilling: Spudded October 11, 1951; completed December 17, 1951.

Elevation: Ground 32.3 m. (106'). Rotary table 35.7 m. (117').

Stratigraphy, main lithology and paleontology:

0 - 32 m. Danian. Limestone, white. (Kalksten, hvid).

$\left(0^{\prime}-104^{\prime}\right)$

32 - 538 m. Upper Cretaceous, Senonian, ?Turonian, ?Cenomanian. Chalk

$\left(104^{\prime}-1765^{\prime}\right)$ white, soft, with chert; limestone, white, laminae of marl, greenish grey. (Skrivekridt med flint, og kalksten, hvid med tynde lag af grønliggrå mergel). Angulogavelinella bettenstaedti, Reussella pseudospinulosa, Globorotalites michelinianus, Pseudovalvulineria of. lorneiana, Stensioeina exsculpta, Globotruncana sp.

538 - 818 m. Lower Cretaceous. Claystone, dark grey, greenish grey. (Ler(1765'-2683') sten, mørkegrå og grønliggrå). Ammodiscus sp., Glomospira sp., Haplophragmoides sp., Conorotalites sp., Planularia crepidularis, Ostracods.

818 - 881 m. Upper Jurassic, Malm. Claystone, shaly, silty. (Lersten, fin(2683'-2891') sandet). Protocardium spp., Grammatodon sp., "Ostrea" s. l., ?Pleuromyidae sp., Vaginulina cf. inconstans, Ostracods.

881 - 943 m. Middle Jurassic, Dogger. Sandstone, light grey, claystone, dark (2891'-3095') grey, greyish black, interbedded. (Sandsten, lysegrå, og lersten, mørkegrå og gråsort i afvekslende lag).

943 - 966 m. Cap rock. Anhydrite, grey, dense and limestone, dark grey, in $\left(3095^{\prime}-3169^{\prime}\right)$ top. Laminae of clay, dark grey, throughout. (Anhydrit, grå, tæt, og kalksten, mørkegrå øverst. Tynde lag af ler, mørkegråt, $\mathrm{i}$ hele intervallet).

$966-1240$ m. Salt dome. Rock salt, rather pure, greyish white to translucent. $\left(3169^{\prime}-4069^{\prime}\right) \quad$ (Stensalt, ret rent, grålighvidt til gennemskinneligt).

Well geologists: J.F.F.; K.J.L.; J.B.S.

Micropaleontologists: A.N.; R.W.

Paleontologists: P.H.B.; T.S.

Schlumberger interpreters: J.A.N.; T.S. 


\section{Ullerslev No. 1 - D.G.U. File No. 146.172.}

Gravity anomaly: Located in an intermediate position between residual gravity maximum " 53 " and minimum "AX".

Seismic survey: a. Reflection. Pinch-out below the Upper-Lower Cretaceous unconformity at shot point " 122 " on profile "F-1". No final control on closure.

b. Refraction: None.

Objective: A test of the pinch-out zone below the Upper Cretaceous and above the Middle Keuper.

Location: About $12 \mathrm{~km}$. NW of Nyborg City and about $1.5 \mathrm{~km}$. NW of Ullerslev railway station. Coordinates: $55^{\circ} 22.23^{\prime} \mathrm{N} ; 1^{\circ} 55.98^{\prime} \mathrm{W}$ of Copenhagen Observatory.

Drilling: Spudded May 2, 1951; completed June 11, 1951.

Elevation: Ground 22.0 m. (72'). Rotary table $25.3 \mathrm{~m}$. (83').

Stratigraphy, main lithology and paleontology:

0 - 15 m. Pleistocene. Glacial drift. (Istidsdannelser).

$\left(0^{\prime}-49^{\prime}\right)$

15 - 47 m. Paleocene. Marl, greenish grey, silicified shale beds. (Mergel,

$\left(49^{\prime}-154^{\prime}\right)$ grønliggrå med forkislede skiferlag). Pseudovalvulineria sp., Clavulina cf. parisiensis.

47 - 96 m. Danian. Bryozoan limestone, much chert. (Bryozokalk, flintrig). $\left(154^{\prime}-314^{\prime}\right)$

96 - $801 \mathrm{~m}$. Senonian-Cenomanian. Chalk, white, and limestone. (Skrive$\left(314^{\prime}-2629^{\prime}\right)$ kridt og kalksten). Bolivina incrassata, Gavelinopsis cenomanica.

$801-820 \mathrm{~m}$. Lower Cretaceous, Albian-Aptian. Claystone, light brown, $\left(2629^{\prime}-2689^{\prime}\right)$ reddish brown, sticky, calcareous. (Lersten, lysebrun, rødbrun, fed, kalkholdig). Glomospira sp., Hedbergella spp., Gavelinella sp., Conorotalites aptiensis.

820 - 826 m. Lower Cretaceous, Aptian-Hauterivian. Clay, bluish black, soft, $\left(2689^{\prime}-2709^{\prime}\right)$ shale, dark grey, at base sandstone, dark greenish grey. Oolites. (Ler, blåsort, blødt og lersten, mørkegrå, nederst sandsten, mørk grønliggrå). Marginulina sp., Planularia crepidularis, Pelecypods.

826 - 978 m. Rhaetic. Shale and claystone, dark and light grey, interbedded $\left(2709^{\prime}-3209^{\prime}\right)$ with sandstone, light grey. (Lersten, mørkegrå og lysegrå, vekslende med sandsten, lysegrå). Ostracods, Freshwater Molluscs, Plant remains.

$978-1060 \mathrm{~m}$. Rhaetic and ?Keuper. Claystone, brown and green, interbedded. $\left(3209^{\prime}-3477^{\prime}\right)$ Patches and streaks of varicoloured claystone. Lower parts with anhydrite. (Lersten, brun og grøn i vekslende lag. Uregel- 
mæssige partier og striber af broget lersten. Nedre del med anhydrit).

Well geologists: J.F.F.; K.J.L.; G.L.; G.V.O.

Micropaleontologists: A.N.; R.W.

Paleontologist: R.W.

Lithology: R.W.

Schlumberger interpreter: J.A.N.

Vedsted No. 1 - D.G.U. File No. 25.45.

Gravity anomaly: Structure not related to any apparent gravity anomaly.

Seismic survey: Reflection. The shallower reflection horizon near the base of the Upper Cretaceous indicates a NNW-SSE trending structure of anticlinal type. The steeper gradient is to the $\mathrm{W}$ of the crest, a moderate gradient to the $\mathrm{N}$ and a flattening gradient to the SSE along the crest. The eastern flank of the structure is suggested to have a steeper gradient to the $\mathrm{E}$ in the northern part. A shallow $\mathrm{E}$ gradient in the southern part indicates connection with a smaller anomaly with questionable fault closure to the E. The Haldager No. 1 deep test was located on this smaller feature.

The deeper reflection horizon is based on poor data. It suggests a NW-SE trending high offset to the SW from the probable Cretaceous anomaly.

Vedsted No. 1 deep test is located on the SW flank close to the crest of the probable Cretaceous structure and on the NE flank of the closure of the deeper reflection horizon.

The shallower reflection horizon indicates about $70 \mathrm{~km}^{2}$. of closed area.

Previous core drill results: Ö. Halne No.s 1-6 give no contribution to the structure pattern in the region of Vedsted No. 1.

Objective: Test of the Lower Cretaceous-Jurassic-Rhaetic sequence to check the suggested closures for oil and gas accumulation.

Location: About $18 \mathrm{~km}$. NW of Nörre Sundby and $1.2 \mathrm{~km}$. SW of Birkelse railway station. Coordinates: $57^{\circ} 08.432^{\prime} \mathrm{N} ; 2^{\circ} 54.462^{\prime} \mathrm{W}$ of Copenhagen Observatory.

Drilling: Spudded May 9, 1958; completed June 8, 1958.

Elevation: Ground $2.0 \mathrm{~m}$. Rotary table $5.3 \mathrm{~m}$.

Stratigraphy, main lithology and paleontology:

0 - $37 \mathrm{~m}$. Pleistocene. Glacial drift. (Istidsdannelser).

$37-427 \mathrm{~m}$. Senonian and Turonian. Chalk, white, soft, chert, lower parts with marl, whitish green, shale, dark grey. (Skrivekridt med flint, nedre del med hvidliggrøn mergel og mørkegrå lersten). Bolivinoides draco draco, Bolivina incrassata, Stensioeina pomme- 
rana, Reussella pseudospinulosa, Globotruncana sp., Globorotalites sp.

427 - 457 m. Cenomanian. Marl, whitish green, trace of shale, dark grey. (Mergel, hvidliggrøn med spor af mørkegrå lersten). Cibicides formosus, Gavelinopsis cenomanica.

457 - 623 m. Albian-Aptian. Claystone, dark grey, soft, silty; shale, dark grey, very silty, glauconitic, slightly micaceous. (Lersten, mørkegrå, finsandet og lerskifer, mørkegrå, meget finsandet, med glaukonit og svagt glimmerholdig). Hedbergella sp., Gavelinella sp., Lenticulina sp., Haplophragmoides sp., Epistomina spinulifera.

623 - 707 m. Barremian. Claystone, dark grey, soft, silty, locally pyritic. (Lersten, mørkegrå, blød, finsandet, stedvis pyritisk). Vaginulina sp., Lenticulina sp., Haplophragmoides sp.

$707-840 \mathrm{~m}$. Hauterivian. Claystone, dark grey, soft, slightly silty and slightly pyritic. (Lersten, mørkegrå, blød, svagt finsandet og svagt pyritisk). Triplasia emslandensis emslandensis, Lagena hauteriviana hauteriviana, Epistomina caracolla, Marginulinopsis cf. oldenburgensis.

840 - 979 m. Valanginian. Claystone, dark grey, soft, some shale, dark grey, slightly fissile. (Lersten, mørkegrå, blød med lerskifer, mørkegrå, svagt spaltelig). Ammovertella cellensis, Epistomina caracolla, Protocythere cf. 504 (Klingler det.).

979 -1057 m. Upper Jurassic, Malm. Claystone, greenish grey, locally very silty. (Lersten, grønliggrå, stedvis meget finsandet). Planularia sp., Haplophragmoides sp., Saracenaria sp.

1057 -1376 m. Middle Jurassic, Dogger. Claystone, greenish grey, very silty, micaceous; shale, grey, slightly fissile, sandy, micaceous; sandstone, grey and yellowish brown, very friable. (Lersten, grønliggrå, meget finsandet, glimmerholdig; lerskifer, grå, svagt spaltelig, sandet, glimmerholdig og sandsten, grå og gulligbrun, meget løst sammenkittet). Plant remains, Haplophragmoides sp., Ammobaculites sp., Vaginulina harpa, Reinholdella cf. dreheri, Ostracod sp. 101 (Klingler det.).

1376 -1899 m. Lower Jurassic, Lias. Shale, grey, dark grey, fissile, locally trace of siltstone, white, locally siderite. (Lerskifer, grå, mørkegrå, spaltelig, stedvis med spor af finsandsten, hvid, stedvis siderit). Geinitzina tenera, Marginulina sp., Marginulina prima, Procytheridea $\mathrm{c} f$. laqueta (Klingler det.).

$1899-2065$ m. Rhaetic. Siltstone, white; shale, grey; thin interbedded streaks, crossbedding; sandstone, white, coal seams. Basal $6 \mathrm{~m}$.: conglomerate, arkosic, sandstone, arkosic, coal inclusions, shale, mottled red and green. (Finsandsten, hvid og lerskifer, 
grå vekslende i tynde lag, krydslejring, og sandsten, hvid med bånd af kul. Nederste $6 \mathrm{~m}$ : arkosekonglomerat og arkoseagtig sandsten med kul og skifer, broget rød og grøn). 2003-2009 m: Cladophlebis sp. (leaves).

Well geologists: A.F.B.; L.B.R.

Micropaleontologist: A.B.

Schlumberger interpreters: A.F.B.; J.M.D.; T.S.

Vemb No. 1 - D.G.U. File No. 63.174.

Gravity anomaly: About $1 \mathrm{~km}$. NW of the centre of a residual gravity nose $\mathrm{N}$ of residual gravity maximum " 19 " and between residual gravity minima "P", Gording, and "E", Linde.

Seismic survey: Reflection. A well defined interdomal structure of anticlinal type. The reflection horizon near the base of the Upper Cretaceous indicates approximately $75 \mathrm{~m}$. of closure covering about $16 \mathrm{~km}^{2}$. Complex faulting in the eastern and southern parts of the structure is suggested. A second reflection horizon at greater depth, probably near the base of the Rhaetic, indicates an anticlinal structure with almost the same geographical situation as indicated by the shallower horizon. Minimum closure on the deeper horizon about $300 \mathrm{~m}$. covering an area of more than $25 \mathrm{~km}^{2}$.

Previous core drill results: None.

Objective: To test seismic indicated closure for oil and gas accumulation in the Lower Cretaceous-Jurassic-Rhaetic strata.

Location: About $16 \mathrm{~km}$. W of Holstebro and $4.3 \mathrm{~km}$. NNE of Vemb railway station. Coordinates: $56^{\circ} 22.884^{\prime} \mathrm{N}$; $4^{\circ} 12.886^{\prime} \mathrm{W}$ of Copenhagen Observatory.

Drilling: Spudded December 14, 1957; completed January 27, 1958.

Elevation: Ground $12.2 \mathrm{~m}$. Rotary table $15.7 \mathrm{~m}$.

Stratigraphy, main lithology and paleontology:

0 - ?20 m. Pleistocene. Glacial drift. (Istidsdannelser).

?20 - $391 \mathrm{~m}$. Miocene. Mica clay and -silt, greyish black and light grey, quartz sand and quartz gravel, grey. (Glimmerler og glimmersand, gråsort og lysegråt, kvartssand og kvartsgrus, gråt). Cibicides pseudoungerianus, Nonion soldanii.

391 - 453 m. Oligocene. Mica clay, greenish grey, glauconitic. (Glimmerler, grønliggråt, glaukonitisk). Uvigerina sp., Asterigerina gürichi, Angulogerina sp., Sphaeroidina variabilis.

453 - 471 m. Oligocene-Eocene. Clay, whitish grey, highly calcareous. (Hvidgråt ler, særdeles kalkrigt). Globigerina sp. 
471 - 518 m. Eocene. Clay, greyish white, highly calcareous, marl, yellowish grey. (Ler, gråhvidt, særdeles kalkrigt og gulliggrå mergel). Bulimina aff. truncanella, Alabamina sp., Globigerina sp.

518 - 545 m. Eocene. Clay, greenish grey, brownish grey, sticky. (Ler, grønliggråt og brunliggråt, fedt).

545 - 564 m. Eocene. Clay, brick red, sticky. (Ler, teglrødt, fedt). Cibicides sulzensis, Gaudryina hiltermanni.

564 - 593 m. Eocene. Shale, greenish grey, non calcareous, tuff, banded, black. (Lerskifer, grønliggrå, kalkfri med bånd af vulkansk aske, sort).

593 - 620 m. Paleocene. Shale, light grey, calcareous. (Skiferler, lysegråt, kalkholdigt). Gyroidinoides sp., Bulimina cf. midwayensis.

620 - 659 m. Paleocene. Shale, grey, dark grey, non calcareous. (Skiferler, gråt og mørkegråt, kalkfrit). Bulimina trigonalis.

659 - 787 m. Danian. Limestone, white, greyish white, chert, light grey. (Kalksten, hvid og gråhvid med lysegrå flint). Globigerina spp., Cibicides voltzianus, Gavelinopsis cf. involuta, Osangularia lens.

$787-1325$ m. Senonian. Chalk, white, soft, chert; limestone, white, hard, lower parts with marl, grey. (Skrivekridt med flint og hvid kalksten, hård, nedre del med grå mergel). Buliminella laevis, Pseudotextularia elegans, Bolivinoides draco draco, Stensioeina pommerana, Stensioeina exsculpta, Stensioeina praeexsculpta.

$1325-1342 \mathrm{~m}$. Turonian. Limestone, white, with inclusions of shale, grey, basal parts harder, with chert. (Kalksten, hvid med grå lerskifer, nedre del hårdere, med flint). Globotruncana spp., Stensioeina praeexsculpta.

1342 -1387 m. Cenomanian. Limestone, white, marl, olive green. (Kalksten, hvid og mergel, olivengrøn). Gavelinopsis cenomanica.

1387 -1410 m. Albian-?Aptian. Claystone, reddish brown, calcareous. (Lersten, rødbrun, kalkholdig). Glomospira sp., Gavelinella sp., Haplophragmoides sp., Bigenerina sp., Tritaxia sp.

1410-1554 m. Barremian, Hauterivian, and Valanginian. Claystone, grey, greenish grey, shaly. (Lersten, grå og grønliggrå, med skifer). Conorotalites bartensteini, Planularia crepidularis, Epistomina caracolla.

1554 -1587 m. Middle Jurassic, Dogger. Claystone and shale, dark grey, silty, and siltstone, grey, glauconitic. (Lersten og -skifer, mørkegrå, finsandet, og finsandsten, grå, glaukonitisk). Lenticulina d'orbignyi, Reophax cf. metensis, Haplophragmoides canariensis.

1587 -1792 m. Lower Jurassic, Lias. Claystone and shale, dark grey, greyish black. (Lersten og -skifer, mørkegrå, gråligsort). Marginulina prima, Reophax multilocularis, Planularia inaequistriata.

$1792-1956$ m. Triassic, Rhaetic-?Keuper. Siltstone, greenish grey, micaceous, 
limonitic inclusions, downwards with lignite and shale, interchanging, patches of olive shale. (Finsandsten, grønliggrå, glimmerholdig med limonitiske indeslutninger, nedefter med lignit og lerskifer, afvekslende i tynde lag og uregelmæssige partier af lysegrøn lerskifer).

Well geologists: A.F.B.; L.B.R.

Micropaleontologist: A.B.

Schlumberger interpreters: A.F.B.; J.M.D.

\section{Vinding No. 1 - D.G.U. File No. 74.94.}

Gravity anomaly: Centre of residual gravity minimum "W" with a negative relief of about 3 mgal suggesting a deep or semi-deep salt anticline.

Seismic survey: a. Reflection. Not worked when the well was spudded in.

b. Refraction. Interpretation of results complicated due to two refraction horizons being close together: a $4240 \mathrm{~m}$./s. horizon at 3400' (ca. $1040 \mathrm{~m}$.) and another $3600 \mathrm{~m}$./s. horizon at 3700' (ca. $1130 \mathrm{~m}$.) over the crest. The feature as finally outlined conformed in position, size and shape to the "W" gravity minimum, and it was felt that it represented geologic structure in the section above a deep seated salt dome. Closure very small and poorly defined.

Previous core drill results: None.

Objective: A test of the Lower Cretaceous-Jurassic- and Zechstein sequence.

Location: About $8.8 \mathrm{~km}$. SE of Holstebro Central station and $3.6 \mathrm{~km}$. S to $\mathrm{W}$ of Tvis railway station. Coordinates: $56^{\circ} 17.43^{\prime} \mathrm{N} ; 3^{\circ} 52.73^{\prime} \mathrm{W}$ of Copenhagen Observatory.

Drilling: Spudded July 17, 1947; completed December 24, 1947.

Elevation: Ground 56.7 m. (186'). Rotary table 61.6 m. (202').

Stratigraphy, main lithology and paleontology:

0 - $? 59 \mathrm{~m}$. Pleistocene. Sand, gravel, glacial drift. (Sand, grus, istidsdan-

$\left(0^{\prime}-? 193^{\prime}\right)$ nelser $)$.

?59 - $292 \mathrm{~m}$. Miocene. Mica sand, grey, and mica clay, brown. (Glimmer$\left(? 193^{\prime}-959^{\prime}\right)$ sand, gråt og glimmerler, brunt). Cibicides pseudoungerianus.

292 - 352 m. Oligocene. Clay, greenish grey, brownish grey. (Ler, grønliggråt $\left(959^{\prime}-1154^{\prime}\right)$ og brunliggråt). Asterigerina gürichi, Ceratobulimina contraria.

352 - 475 m. Eocene. Clay, whitish grey, greenish tinge, greyish brown, $\left(1154^{\prime}-1559^{\prime}\right)$ reddish brown, basal parts with tuff. (Ler, hvidgråt med grønt skær, gråligbrunt og rødligbrunt. Nederst med vulkansk aske). Vaginulinopsis decorata, Globigerinoides sp.

475 - 548 m. Paleocene. Shale, dark grey, bluish grey. (Skiferler, mørkegråt $\left(1559^{\prime}-1797^{\prime}\right)$ og blågråt). Spiroplectammina spectabilis, Osangularia sp., Gaudryina $s p$. 
548 - 670 m. Danian. Limestone, whitish grey, chert. (Kalksten, hvidgrå $\left(1797^{\prime}-2199^{\prime}\right)$ med flint).

$670-1292$ m. Upper Cretaceous. Chalk, white, soft, chert; limestone, white, $\left(2199^{\prime}-4239^{\prime}\right) \quad$ whitish grey, beds and laminae of marl, greenish grey. (Skrivekridt med flint og kalksten, hvid og hvidgrå med lag af grønliggrå mergel). Stensioeina pommerana, Bolivina incrassata, Stensioeina exsculpta.

$1292-1367$ m. Lower Cretaceous, Albian, Valanginian. Claystone, reddish $\left(4239^{\prime}-4484^{\prime}\right)$ brown, dark grey, greyish black with interbedded sand. (Lersten, rødbrun, mørkegrå, gråsort, vekslende med sandlag). Gavelinella sp., Planulina sp., Glomospira sp., Planularia crepidularis.

$1367-1453$ m. ?Middle Jurassic. Claystone, sandy, greyish brown. (Lersten, (4484'-4766') sandet, gråbrun). Vaginulina sp.

$1453-1580$ m. Lower Jurassic, Lias alpha-beta. Shale, bluish grey, dark grey, $\left(4766^{\prime}-5184^{\prime}\right)$ concretionary clay ironstone. (Lerskifer, blågrå, mørkegrå, med lerjernstenskonkretioner). Aegoceras planicosta, Modiola sp., Pentacrinus sp., Ammodiscus asper, Marginulina prima praerugosa, Geinitzina tenera tenuistriata, Planularia inaequistriata, Astacolus sp., Ostracods, Holothurian remains.

$1580-1763 \mathrm{~m}$. Rhaetic. Claystone, shaly, dark grey, sand, fine, light grey, $\left(5184^{\prime}-5784^{\prime}\right)$ interlaminated. (Lersten, skifret, mørkegrå, og fint sand, lysegråt i afvekslende lag). Pteria contorta, Protocardia sp. indet., Fish remains.

1763 -2174 m. Keuper. Claystone, sandy, varicoloured, reddish brown, greyish $\left(5784^{\prime}-7134^{\prime}\right)$ green; anhydrite and dolomite. (Lersten, sandet, broget, rødbrun og gråliggrøn med anhydrit og dolomit). In basal part of interval: Chara oogoniae.

$2174-2429$ m. ?Muschelkalk. Claystone, varicoloured, reddish brown, brown$\left(7134^{\prime}-7969^{\prime}\right)$ ish grey, greyish green, with anhydrite. (Lersten, broget, rødbrun, brungrå og grågrøn, med anhydrit).

Well geologist: J.E.F.

Micropaleontologist: A.N.

Paleontologist: H.F.

Lithology: M.H. 


\title{
DANSK SAMMENDRAG
}

\author{
DYBDEBORINGER I DANMARK 1935-1959
}

INDLEDNING. KORT OVERSIGT OVER OLIEEFTERFORSKNINGEN.

Olieefterforskningen i Danmark indtil 1959 er skitseret af HILMAR ØDUM (1960) i oversigten over saltefterforskningen.

I indledningskapitlet til det foreliggende arbejde nævnes de vigtigste begivenheder, der fandt sted i løbet af den 24-årige efterforskningsperiode.

Det koncessionerede selskab, Danish American Prospecting Company, tog fra 1938 de mest moderne metoder i brug. Man gennemførte en meget nøjagtig kortlægning af tyngdeforholdene $\mathrm{i}$ hele landet med undtagelse af Bornholm og fik derved et tilnærmet billede af undergrundens struktur. Ved de efterfølgende seimiske undersøgelser, der omfattede såvel refraktions- som reflektionsmålinger, og ved hjælp af strukturboringer til forholdsvis ringe dybde, blev en lang række tyngdeanomalier kortlagt. Efterhånden som kortlægningen skred frem, og undergrundens højdestrukturer aftegnede sig, udførtes dernæst de 31 dybdeboringer, som er dette arbejdes hovedemne.

Boringerne er udført med 4 forskellige boretårne. Strukturboringerne blev udført med et transportabelt tårn af typen »Sullivan « og et »Cardwell« boretårn, model $\mathrm{R}$, mens de egentlige olieboringer og de dybe stratigrafiske boringer blev boret med »Cardwell« tårnet og to »Emsco« boretårne, model J-750 og 800 (se pl. 12).

\section{BAGGRUNDEN FOR OLIEEFTERFORSKNINGEN I DANMARK}

Incitamentet til de danske olieundersøgelser fremkom ved fundet af en række oliefelter i Nordtyskland i tidsrummet mellem de to verdenskrige. Det nordligste af oliefelterne lå ved Heide, kun ca. $80 \mathrm{~km}$ syd for den dansk-tyske grænse.

På dette tidspunkt havde man endnu ikke noget kendskab til formationerne under senoniet i Danmark vest for Øresund. Der var dog god grund til at antage lignende forhold som i Tyskland. Salt grundvand forskellige steder i landet blev tolket som tegn på saltaflejringer under kridtet. Dertil kom end- 
videre, at forskellige geofysiske undersøgelser, som blev foretaget i slutningen af tyverne og begyndelsen af trediverne af Geodætisk Institut og Danmarks Geologiske Undersøgelse, tydede på tilstedeværelsen af tektoniske strukturer af lignende art som i Tyskland.

Når man ser bort fra de små forekomster af metan i de kvartære aflejringer i Vendsyssel og i det sydlige Danmark, kendte man imidlertid ikke til kulbrinteforekomster af betydning i Danmarks undergrund.

Efterforskningsarbejdet i Danmark tog først og fremmest sigte på fremskaffelsen af konkrete oplysninger om den dybere undergrunds geologi, idet man navnlig var interesseret i, om de olie- og gasførende formationer, som man havde påvist i de nærliggende tyske områder, strakte sig ind under Danmark. Det var den herskende opfattelse, at olien og gassen i zechsteinen i Tyskland var dannet i den producerende formation. Zechstein aflejringerne blev derfor til at begynde med hovedmålet for olieboringerne i Danmark.

De nye oliefund, som blev gjort i Tyskland efter Anden Verdenskrig, afslørede, at andre formationer end zechstein kunne indeholde olie. Især sandstenslagene i juraen og i nedre kridt viste sig at være olieproducerende i adskillige strukturer. Følgen heraf blev, at man ved undersøgelserne i Danmark efter krigen rettede opmærksomheden, ikke blot mod zechsteinen, men også mod de mesozoiske lag.

\section{EFTERFORSKNINGSARBEJDERNE}

A. TYNGDEMÅLIngerne. Målingerne blev foretaget med Gulf gravimeteret. De beregnede Bouguerværdier er behæftet med en middelfejl på 0,06 milligal. I øvrigt findes en oversigt over det udførte opmålingsarbejde på side 11 .

Resultaterne sammenstilledes i form af kurvekort i 1:100.000 over Bouguer anomalierne. Fortolkningen af disse kort og udarbejdelsen af residualtyngdekort i 1: 100.000 blev foretaget af Dr. Sigmund Hammer (se pl. 14-16).

Det vigtigste resultat af tyngdemålingerne blev opdagelsen af den nordjyske salthorstprovins, der på tyngdekortet fremtræder som et område med dybe, runde minima omkring Limfjorden. En anden betydningsfuld erkendelse var, at der syd for salthorstprovinsen findes et regionalt maksimum, den såkaldte Ringkøbing-Fyn højderyg. Den er særlig karakteristisk på residualtyngdekortet, hvor den er opløst i et system af NNV-SSØ strygende lokale tyngdemaksima. De blev tolket som højtliggende grundfjeldshorste med mellemliggende gravsænkninger (se også SoRGENFREI 1959, p. 43).

Syd for Ringkøbing-Fyn højderyggen findes på den sydlige del af Sønderjyllands østkyst de nordlige udløbere af kraftige minima, hvis hovedudbredelse ligger på tysk område. De blev tydet som resultatet af zechsteinsaltets oppresning og antoges at repræsentere de nordligste partier af de langstrakte holstenske saltrygge.

Ved tolkningen af de geofysiske resultater støttede man sig på alle tilgængelige 
geologiske data. Oplysningerne i Danmarks Geologiske Undersøgelses borearkiv blev blandt andet stillet til rådighed, og de ikke-publicerede resultater af D.G.U.'s undersøgelser over prækvartæret blev frigivet til brug ved fortolkningsarbejdet.

B. SEISMISKE UNDERSøGELSER. I 1939 påbegyndtes seismiske refraktionsmålinger i salthorstprovinsen i Nordjylland. Efter afbrydelsen under krigen fortsattes refraktionsmålingerne til 1947, idet de efterhånden udstraktes til Sønderjylland. Udenfor salthorstprovinsen var resultaterne imidlertid af så ringe kvalitet, at man praktisk taget opgav refraktionsmetoden til fordel for refleksionsmålinger. Store områder af Nord- og Sønderjylland, og dele af Lolland og Sjælland, blev herefter kortlagt refleksionsseismisk. Blandt refleksionshorisonterne var følgende de vigtigste:

1. Terticerets basis. Denne refleksionshorisont er øjensynlig betinget af forskellen i lydhastighed i de tertiære ler- og skiferlag og den underliggende hårde danskekalk. Da niveauet ikke har særlig oliegeologisk betydning, blev der ikke tegnet kurvekort over denne flade.

2. Øvre kridts basis. Dette er den mest karakteristiske refleksionshorisont i seismogrammerne. Den blev kaldt for »top af nedre kridt « under eksplorationsarbejderne, selv om refleksionen uden tvivl er knyttet til den hårde turon kalksten, der findes et stykke over toppen af nedre kridt. Der blev almindeligvis fremstillet kurvekort for dette niveau.

3. Top af mellem keuper. Denne horisont, som danner grænsen mellem rhaet og mellem keuper, blev under kortlægningen konventionelt kaldt for »top af keuper «. Begrundelsen var den, at rhaetaflejringerne, der består af sandsten og skifre, repræsenterer begyndelsen til en ny sedimentationscyklus, som fortsætter i lias.

I princippet forefindes ved grænsefladen rhaet-mellem keuper forhold, der minder om situationen ved tertiærets basis: skifre og sandsten med relativt ringe lydhastighed er underlejret af en tæt, massiv mergelsten eller lersten med større lydhastighed. Refleksionshorisonten var dog ikke altid let at identificere under de seismiske arbejder. Der blev kun undtagelsesvis tegnet kurvekort over dette niveau.

4. Top af øvre perm zechstein salt. Denne horisont svarer til hastighedsændringen ved overgangen fra sandstenen og siltstenen i nedre trias til stensaltet i zechsteinformationen. Der blev tegnet kurvekort over saltoverfladen, hvor det var muligt.

5. Top af C3-dolomiten. Refleksionsfladen svarer tilnærmelsesvis til grænsen mellem C4-anhydriten og C3-dolomiten. I områder med tykke stensaltaflejringer var den normalt den dybeste refleksionshorisont.

6. Top af prakambrisk grundf jeld. Det lykkedes at opfange refleksioner fra prækambriets overflade på Ringkøbing-Fyn-højderyggen. 
De seismiske resultater blev fremlagt i form af seismiske profiler og kurvekort. Da refleksionernes kvalitet skiftede fra egn til egn, var det ikke muligt at tegne kort for alle de nævnte refleksionsflader.

Følgende geofysikere ved DANISH AMERICAN PROSPECTING COMPANY har udført beregnings- og fortolkningsarbejdet ved de seismiske undersøgelser: A. H. MAC Kee, H. Mac Grew, P. Jensen, J. C. Johnson, M. C. Hogue, R. Slettene og M. Spaeth.

Desuden har følgende medlemmer af GULF RESEARCH AND DEVELOPMENT COMPAny's stab deltaget i bearbejdelsen: H. MAC Grew og J. RoBInson.

C. GEOLOGISKE ARBEJDER. Ved efterforskningens begyndelse koncentrerede man sig om den biostratigrafiske inddeling af de marine lagserier, som man stødte på ved borearbejderne. Ikke-fossilførende intervaller inddeltes lithostratigrafisk, elektrostratigrafisk, eller kemostratigrafisk. Sideløbende hermed bidrog geologerne ved den strukturelle fortolkning af de geofysiske resultater. Geologiske kort og tværprofiler blev korreleret med tilsvarende geofysiske data. De mange strukturboringer og saltefterforskningsboringer, som er opført i tabellen side 14 var et led heri. Boringernes antal giver et indtryk af omfanget af denne del af det geologiske arbejdsprogram. Beliggenheden fremgår af kortet pl. 17.

Regionale studier af palæogeografiske forhold og kulbrinternes forekomstmåde, som også udstraktes til vore nabolande, gennemførtes på et senere stadium. Forskellige palæogeografiske kort blev udarbejdet på grundlag af disse studier til støtte for planlægningen af eksplorationsarbejderne.

I visse dele af landet, som f. eks. Sønderjylland og Vendsyssel, blev der udført relativt mange olieboringer, mens store dele af Midtjylland og flere af øerne er forholdsvis ufuldstændigt undersøgt med hensyn til de ældre prækretaciske formationer. Det lykkedes således ikke at få gennemboret saltserien i det nordjyske zechstein bassin, og syd for Ringkøbing-Fyn højderyggen nåede man længst mod syd ikke dybere ned i lagserien end til nedre perm rotliegendes.

Borejournalerne for de 31 dybdeboringer, der omfatter såvel de egentlige olieboringer som de stratigrafiske boringer, findes på side 28-90. De repræsenterer en betydelig forøgelse af vort kendskab til Danmarks geologi, idet man før olieefterforskningen tog sin begyndelse, som nævnt tildligere, ikke havde kendskab til lagene under senoniet vest for Øresund.

Den følgende kortfattede beskrivelse af den prækvartære geologi gør især rede for den mest betydningsfulde nye geologiske erkendelse. 


\section{A. SEDIMENTATIONSBASSINET OG DETS STRATIGRAFI}

I regional henseende hører Danmark til det nordvest-europæiske aflejringsbassin sammen med Sydsverige (Skåne), Nordtyskland, Holland og Østengland. Mod øst er det danske aflejringsområde begrænset af Fennoskandias højtliggende prækambriske grundfjeld. Ved de hidtil udførte dybdeboringer har man påvist formationerne, som er opført i skemaet side 22. Den mest fuldstændige lagserie er konstateret i Det Danske Sænkningsområde mellem den Fennoskandiske Randzone og Ringkøbing-Fyn Højderyggen.

Det karakteristiske for højderyggen er, at juraaflejringerne og væsentlige dele af nedre kridt mangler, samt at prækambriet ligger meget højt, sammenlignet med det danske sænkningsområde.

Det er ikke hensigten her at gøre rede for alle stratigrafiske detaljer i de enkelte boringer. Den følgende korte gennemgang af de anvendte stratigrafiske inddelingsmåder i relation til den opstillede stratigrafi og oversigten over formationernes tilstedeværelse i boringerne vil kunne illustrere, hvor sikre eller usikre de stratigrafiske konklusioner er, og hvilke palæogeografiske problemer, der stadig er uløste.

Prakambrium. Der henvises til omtalen af boringerne Frederikshavn no. 1, Grindsted no. 1 og Glamsbjerg no. 1.

Kambrium. Sandsten og skifre af kambrisk alder går som bekendt frem til overfladen på Bornholm og i Skåne. Desuden er de mørke skifre og den kvartsitiske sandsten under de ordovicisk-siluriske skifre i Slagelseboringen henført til kambrium på grund af deres stratigrafiske beliggenhed og seriens lighed med kambriet i Skåne og på Bornholm.

Det er ikke muligt at udtale sig med sikkerhed om kambriets udbredelse i Danmark i øvrigt. Men i betragtning af, at det forekommer i det baltiske område, i Oslofeltet og på Sjælland, er det rimeligt at formode et større aflejringsbassin med lagserier af sandsten, skifre og kalksten under Sjælland med omkringliggende øer, Kattegat og sandsynligvis også under visse egne af Jylland.

Ordovicium-Silur. Lagserien i Slagelseboringen, som er henført til dette formationsinterval, er dateret ved hjælp af sit indhold af graptoliter. Aflejringer af samme type er velkendte i Skåne og på Bornholm, og der er grund til at antage et aflejringsmiljø og et sedimentationsområde af lignende udstrækning som i den kambriske periode.

Pra-perm af ukendt alder. Der knytter sig særlig interesse til de umetamorfoserede præ-zechstein skifre, som er påvist ved Åbenrå og Hønning. Disse skifre er principielt forskellige fra de typiske rotliegend lag af rødlig sand- og siltsten, som forekommer under zechsteinaflejringerne i Tønder-, Böxlund- og 
Rødbyboringerne. Skifrene ved Hønning og Åbenrå indeholder øjensynlig ingen fossiler. Nogen biostratigrafisk datering foreligger derfor ikke. Alle forhold taget i betragtning er det mest sandsynligt, at der er tale om nedre palæozoiske skifre af kambro-silurisk alder; men der må heller ikke ses bort fra den mulighed, at der kan foreligge lag fra karbontiden.

Nedre perm. De rødlige sand- og siltsten under kalkstenen, som med sikkerhed har kunnet henføres til øvre perm og er korreleret med zechsteinkalk i Tyskland, er henregnet til nedre perm. På grund af ligheden med rotliegend-sedimenterne i Nordtyskland og den stratigrafiske beliggenhed under zechsteinkalkzonen, er de danske sedimenter også betegnet som rotliegend-aflejringer. Hidtil har man kun påvist disse lag $\mathrm{i}$ de dybe boringer syd og øst for Ringkøbing-Fyn højderyggen. Da der imidlertid forekommer nedrepermisk sandsten i Osloområdet, er der god grund til at vente nedrepermiske lag også i det danske sænkningsområde nord for højderyggen.

Opdagelsen af en tyk vulkansk serie i tilknytning til nedre perm aflejringerne ved Rødby vakte berettiget opsigt. Nogen sikker datering af vulkanismen foreligger endnu ikke. I betragtning af, at der foregik en livlig vulkansk virksomhed både syd og nord for Danmark i nedre perm og på grund af de stratigrafiske forhold ved Rødby, kan man indtil videre med føje anse Rødbyekstrusiverne for at være af nedrepermisk alder.

De formodede basaltiske bjergarter nederst i Rødekro-boringen er muligvis af samme alder. Her synes usikkerheden med hensyn til aldersforholdet dog at være større, idet eruptivbjergarten ved Rødekro forekommer under triassiske aflejringer. Da der måske kan være tale om en intrusiv basalt bør man afvente resultatet af nøjere undersøgelser, før den her foreslåede datering godkendes.

Øvre perm. De dolomitiske kalkstenslag, som findes ved basis af den tykke evaporitserie, der er korreleret med zechsteinsaltserien i Tyskland, indeholder arter af bryozoer, som både forekommer i zechsteinkalken i Tyskland og i Lower Magnesian Limestone i England. Evaporitseriens basale kalkstensinterval hører derfor til samme biozone som de nævnte to formationer i vore nabolande. Den danske evaporitserie er inddelt i fem inddampningscykler (A-E), som atter er inddelt i overensstemmelse med inddampningsfaserne. Cyklus A ligger øverst og E nederst, idet inddampningscyklerne blev defineret i den rækkefølge, de blev gennemboret (Sorgenfrei 1957 b). Dette skete ud fra betragtningen, at man i de marginale områder af evaporitbassinet, hvor zechsteinboringerne hidtil er udført, ikke kunne vente en så fuldstændig evaporitserie som i de hidtil ukendte centrale dele.

Ved at inddelingen er begyndt fra oven, er der skabt en mulighed for at fortsætte inddelingsprincippet, selv om der i fremtiden skulle blive opdaget endnu ældre inddampningscykler f. eks. i de dybe dele af det danske sænkningsområde. 
De øverste cykler A, B og C kan forholdsvis let korreleres med den tilsvarende zechsteinserie i Nordtyskland. Derimod afviger D og E cyklerne betydeligt fra Werra cyklen i dens typeområde, Werra bassinet, ved ikke at indeholde stensalt. D og E cyklerne i Danmark svarer langt bedre til nedre zechsteins marginale udvikling, som den kendes ved randen af det store nordvesttyske evaporitbassin ved Pyrmont og Detmold i Niedersachsen. (STILlE 1930). Forklaringen på variationen i sedimentationen af evaporitbjergarterne er uden tvivl, at der i begyndelsen af øvre perm fandtes lokale bassiner, hvor der skete en inddampning, der var ret uafhængig af udviklingen i det store hovedbassin. Det vil være en frugtbar tanke at forestille sig et system af laguner, som med hensyn til saltudskillelsen ikke nødvendigvis har haft den samme historie. Og hvis deres inddampningsserier skulle være kommet til at ligne hinanden, er det ikke ensbetydende med, at begivenhederne, som førte hertil, fandt sted på nøjagtig samme tid.

Trias. Ligesom ved permserien har det ved inddelingen af triaslagene i vid udstrækning været nødvendigt at nøjes med lithologiske kriterier.

De danske triasaflejringer består af fire store enheder:

a) Nederst findes en kontinental serie af sand- og siltsten med et evaporitinterval foroven. Denne serie korreleres med Buntsandstein i Tyskland.

b) Derover følger en grå, leret kalksten, hvori der er fundet marine fossiler (Rødby no. 1), og som er korreleret med Muschelkalk i Nordtyskland.

c) Over muslingekalken følger derpå grå og brogede ler- og mergelsten, som stedvis indeholder evaporitbjergarter. De henføres til nedre og mellem keuper.

d) Øverst afsluttes triaslagene med marine og deltaiske aflejringer bestående af sandsten og skifre, som hører til rhaet etagen.

I ganske enkelte boringer har det været muligt at korrelere muslingekalken og rhaetaflejringerne på biostratigrafisk grundlag. Men i langt de fleste tilfælde har det været nødvendigt at identificere lagene ved hjælp af skylleprøver og ved elektrostratigrafiske korrelationer fra boring til boring. I denne forbindelse har det været uheldigt, at der mangler elektriske logs fra Vinding og Gassum, og at boringerne nord for Ringkøbing-Fyn højderyggen øjensynlig ikke lader sig korrelere umiddelbart med boringerne i det sydlige Danmark.

Det ser ud til, at den brogede sandsten samt nedre-mellem keuper findes under størstedelen af landet, mens muslingekalken i sin typiske udvikling synes at være begrænset til den sydlige del af landet.

De danske triasaflejringer står uden tvivl i forbindelse med tilsvarende aflejringer under Skåne, Nordtyskland, Nordsøen, Holland og England. Disse triasområder danner tilsammen det nordvesteuropæiske triasbassin. 
Jura. Aflejringerne, der hører til jurasystemet, forekommer hovedsagelig i det danske sænkningsområde. De består nederst af mørke marine skifre med underordnede sandstenslag, som hører til nedre jura (lias). De overlejres af en deltaisk serie bestående af sandsten og skifre, som henføres til mellem jura (dogger), og øverst følger marine skifre og stedvis sandsten, der er identificeret som øvre jura (malm). Lagene er almindeligvis fossilrige, bortset fra doggerlagene og har derfor let kunnet paralleliseres biostratigrafisk med de tilsvarende aflejringer i vore nabolande. Foraminiferer, ostracoder og mollusker har været benyttet ved korrelationerne.

I palæogeografisk henseende sker der øjensynlig en reduktion af aflejringsområdet mellem den fennoskandiske randzone og Ringkøbing-Fyn højderyggen i mellem jura, og der er tegn på, at der sker en mindre udvidelse af området i løbet af øvre jura.

Navnlig liasaflejringerne viser udprægede lighedstræk med de tilsvarende lag i Nordtyskland og Østengland med hensyn til lithologi og fossilindhold. Doggerog malmaflejringerne viser paralleler med Østengland og det nordvestlige Nordtyskland. Derimod er det karakteristisk, at man i Danmark savner vidnesbyrd om en udvikling svarende til evaporitbassinet i Nordvesttyskland i malm. Det danske sænkningsområde var derfor øjensynlig et åbent havområde i den hertil svarende periode.

Kridt. Der er en fundamental forskel mellem Danmarks nedre og øvre kridt i lithologisk henseende.

Skifrene, lerstenene og sandstenslagene i nedre kridt er principielt af samme art som i øvre jura. Der er i begge tilfælde fortrinsvis tale om marine lag, og de nedrekretaciske aflejringer afspejler i virkeligheden, at sedimentationsforholdene stort set forblev uændrede ved overgangen fra øvre jura til nedre kridt. Også med hensyn til formationernes tykkelse ligner de to afsnit hinanden, idet maksimaltykkelserne for malm og nedre kridt findes i samme strøg i det danske sænkningsområde.

Øvre kridts aflejringer består derimod af kalksten, mergel og kridt, der som en meget tyk lagserie praktisk taget dækker alle tidligere dannede formationer. De afslører, at de geografiske forhold ændredes totalt ved øvre kridttids begyndelse, idet havet bredte sig over et større område end tidligere, og formodentlig indtrådte der også en klimaændring.

Den biostratigrafiske inddeling af nedre og øvre kridt har været begunstiget af lagenes rigdom på mikrofossiler.

Tertiar. Med hensyn til kendskabet til disse aflejringer har dybdeboringerne ikke bidraget med nye data af betydning. 


\section{B. OVERSIGT OVER DANMARKS TEKTONISKE STRUKTUR}

1. Den regionale struktur. a) Den fennoskandiske randzone. Grænsen mellem det højtliggende fennoskandiske grundfjeldsskjold og det danske sedimentationsområde fremtræder som en bred forkastningszone med retningen NV-S $\varnothing$ - kendt under betegnelsen den fennoskandiske randzone. I Skåne markeres den af landskabet med grundfjeldshorstene og de mellemliggende gravsænkninger mellem Hallandsås-Kullen mod NV og Ystad-Simrishamn mod SØ. Bornholm synes også at høre til denne strukturzone. Mod NV må man søge randzonens fortsættelse i det nordligste Vendsyssel, hvor grundfjeldet ligger relativt højt.

Forskydningerne langs forkastningerne i nærheden af grundfjeldshorstene er formodentlig stedvis af størrelsesordenen $3000 \mathrm{~m}$ eller mere.

b) Det danske sankningsområde. Sydvest for den fennoskandiske randzone følger et dybt sedimentationsbassin, som i Jylland er ca. $200 \mathrm{~km}$ bredt og i det sydlige Kattegat og Sjælland indsnævres til 125-150 km bredde. Det har været omtalt tidligere under betegnelsen Det Danske Sænkningsområde, idet det har reageret som en regional strukturel enhed gennem lange perioder af den geologiske udvikling. Ringkøbing-Fyn højderyggen danner sænkningsområdets sydvestlige begrænsning.

Afsænkningen i løbet af sedimentationen har været ganske betydelig. Ved en kombination af de forskellige boringers lagserier, ekstrapolationer med hensyn til endnu ikke påviste formationer og hensyntagen til den lokale tektoniske struktur, når man til den konklusion, at minimumsdybden for den prækambriske overflade er ca. $4500 \mathrm{~m}$ i bassinets dybeste dele i Nordjylland. På Sjælland ligger prækambriet sandsynligvis noget højere.

Salthorstprovinsen i Jylland illustrerer zechsteinsaltets strukturelle effekt i dette område. Evaporitserien indeholder stensaltlag med en samlet tykkelse på ca. 800-1000 m. Mellem salthorstene findes over saltet ca. $3000 \mathrm{~m}$ tykke yngre sedimenter af højere massefylde end saltet. Dette system af lette, deformerbare bjergarter dækket af tungere materiale er meget labilt. På grund af saltets plasticitet har systemet været i stand til at foretage strukturelle justeringer, der er mere eller mindre uafhængige af den dybere tektonik. Salthorstene er et håndgribeligt udtryk herfor. På begrænset område er saltet trængt op gennem de overliggende formationer, væsentlig på grund af saltets opdrift.

c) Ringkøbing-Fyn højderyggen. Hovedretningen for dette strukturområde er noget vanskelig at definere på grund af den noget komplekse opbygning og de ret sparsomme oplysninger. Længdeudstrækningen synes at være nordvestlig.

Prækambriet ligger ved Grindsted i 1599 m dybde og ved Glamsbjerg ved $903 \mathrm{~m}$.

Højderyggens sydvestflanke grænser op til det nordtyske sænkningsområde, hvortil det sydligste Sønderjylland hører. Det er naturligt at vælge zechstein- 
bassinets udbredelse som kriterium for sænkningsområdet, hvis grænse i Sønderjylland da kommer til at gå ca. fra Ribe til Åbenrå, hvorefter den bøjer mod øst syd om Fyn.

d) 'Det 'nordtyske sankningsområdes nordlige randområde. Den sønderjyske del af bassinet karakteriseres ved foldnings- og forkastningsstrukturer, som delvis skyldes bevægelser i zechsteinsaltet. På Sjælland, Lolland og Falster går det nordtyske og det danske sænkningsområde over i hinanden.

2. De lokale strukturformer. a) Den fennoskandiske randzone. Som nævnt er randzonen navnlig karakteriseret ved blokforkastningstektonik. Desuden er sedimentserien foldet adskillige steder. Man kan konstatere, at der er sket bevægelser i palæozoisk og postkretacisk tid, og sandsynligheden taler for, at der er foregået tektoniske forskydninger også i andre perioder.

b) Det danske sankningsområde. Zechsteinsaltets mobilitet har utvivlsomt haft stor betydning for den postpermiske strukturudvikling. En af følgerne er, at eventuelle præpermiske strukturer er blevet tilsløret.

Salthorstene er de dominerende lokalstrukturer. Imellem dem forekommer adskillige steder interdomalstrukturer, der fremtræder som lave folder eller domer. Udenfor salthorstprovinsen findes øjensynlig lave saltantiklinaler og forkastningsstrukturer. De tyder på en reduceret saltserie, en reduceret sedimentserie eller en kombination af begge disse muligheder sammenlignet med forholdene i salthorstprovinsens centrale dele.

c) Ringkøbing-Fyn højderyggen. Området er opdelt ved talrige forkastninger, og der har tydeligvis udviklet sig horste og gravsænkninger, som på Fyn er orienteret NNV-SSØ. Denne retningsafvigelse fra højderyggens nordvestsydøstlige orientering tyder på en échelon struktur.

De seismiske profiler fra Fyn lader formode, at bevægelser har fundet sted i trias, kridt og tertiær. Sandsynligvis er der delvis tale om langvarige, synsedimentære bevægelser.

Slagelseboringen afslørede, at de præpermiske lag hælder stærkt ved højderyggens østende. Bevægelserne, som har fremkaldt denne situation, kan enten have været af caledonisk eller variskisk alder. Dette er af betydelig interesse, da der her er tale om det første, sikre vidnesbyrd om palæozoiske bevægelser i det danske aflejringsområde.

Der er også grund til at nævne vinkeldiskordansen mellem den basale zechstein og de præpermiske skifre i Hønningboringen. Der er en vis sandsynlighed for, at man her står over for virkningerne af den samme tektoniske fase som ved Slagelse.

Med hensyn til tektonikens aldersproblem er det af vigtighed, at de dislocerede skifre ikke er metamorfoserede, hverken ved Slagelse eller Hønning. Dette taler noget til gunst for variskisk tektonik. 
d) Det nordtyske sankningsområdes nordlige randområde. Mellem Tønder og Flensborg findes lave saltantiklinaler (Tønder- og Böxlundstrukturerne). Gennembrudssaltstrukturer findes formodentlig på den sydlige del af Als. Strukturerne på Lolland og Falster ligner de sønderjyske strukturer mellem Tønder og Flensburg. Ved Rødby findes en af landets smukkeste saltantiklinaler, som blev opdaget på rent geologisk indikation.

\section{KULBRINTER}

Der blev konstateret oliespor i Zechsteinseriens dolomitintervaller i følgende boringer og dybder og med de angivne massefylder for olien:

Tønder no. 1

2395-2401 m B3-dolomit, mf. 0,893

3091-3118 m C3-dolomit, mf. 0,922

Tønder no. 2

2994-3019 m C3-dolomit, mf. 0,934

Ábenrå no. 1

2203-2221 m D2-dolomitisk kalksten, (mf. ikke bestemt)

Tønder strukturen fremtræder som antiklinal ned til B3-dolomitten. Også C5-saltet har en disloceret struktur, men der er tydelige tegn på salttektonik i borekernerne. Derimod er C3-dolomitten ikke foldet. Dette dolomitlag ligger som en mod syd hældende monoklinalstruktur, der er begrænset af en ca. NVSØ-strygende forkastning ved Abild, nord for Tønder.

Ved produktionsforsøgene i B3 og C3 dolomitzonerne ved Tønder viste det sig, at intervallerne ikke var i stand til at producere olie. Bjergarterne var for tætte, og i C3-dolomittens spalter fandtes saltvand. Boringen Tønder no. 2, hvor C3-dolomitten ligger $102 \mathrm{~m}$ højere end ved Tønder no. 1, gav ikkebrændbar, stærk kvælstofholdig gas fra C3-dolomitlaget.

Åbenrå boringens D2-kalksten var også uproduktiv. Strukturforholdene ved Åbenrå er uafklarede. Boringen blev i virkeligheden ikke udført som "olieboring", men som stratigrafisk boring.

I Hønning boringen viste B3, C3, D9 og D3 dolomitlagene svage oliespor. Heller ikke i dette tilfælde var der imidlertid tale om fund af betydning.

Under saltefterforskningsboringerne i Suldrup salthorst skete der et gasudbrud fra boringen Suldrup no. 8, mens man borede i Zechstein salt i $452 \mathrm{~m}$ dybde. Udbruddet ophørte ret hurtigt. Alt tyder på, at gassen stammer fra et dolomitlag i salthorsten, muligvis B3-zonen. Gassen indeholdt $84 \% \mathrm{CH}_{4}$ $7 \% \mathrm{C}_{2} \mathrm{H}_{6}$ og højere kulbrinter og ca. $9 \% \mathrm{~N}_{2}$.

Et lignende gasudbrud skete under udførelsen af boringen Tostrup no. 1, 
mens man borede i salt i $513 \mathrm{~m}$ dybde. Gassens sammensætning er ukendt, da det ikke lykkedes at tage en prøve af gassen.

Mindre gasudstrømninger kendes fra boringer, som er ført ned i danskekalken i Nordøstsjælland. Disse forekomster har en vis interesse, fordi de sandsynligvis er præ-øvrekretaciske og derved kunne tyde på kulbrinteholdige aflejringer under kridtet i denne del af det danske sænkningsområde.

I Sydøstsjælland, på Møn og på Falster indeholder grundvandet i kridtet ofte små mængder metan Dens oprindelse kendes ikke med sikkerhed. PAPE har i 1945 fremsat den opfattelse, at metanen skyldes bakterievirksomhed i grundvandet. Det er imidlertid også muligt, at gassen kan stamme fra prækretaciske lag, hvorfra din strømmer op i kridtlagene. At en sådan tanke ikke er helt urealistisk, viser fundet af oliefeltet Reinkenhagen på fastlandet syd for Rügen, kun ca. 100 km SØ for metanområdet.

\section{BOREJOURNALERNE}

På side 26 er der fremsat en række kommentarer til vejledning ved brugen af borejournalerne. Både borejournalerne og de grafiske boreprofiler (tavle 18-22) skulle i øvrigt tale for sig selv. Som nævnt i forordet må journaler og profiler betragtes som foreløbige, idet adskillige problemer er meget ufuldstændigt belyst. Efterhånden som det meget store materiale fra disse boringer bliver endeligt bearbejdet af Danmarks Geologiske Undersøgelse’s stab, må man være forberedt på ændringer i tolkningen og stratigrafisk opfattelse m.v. 


\section{TILLAG}

\section{OPLYSNINGER OM DEN FOSSILE FAUNAS ARTER}

Dybdeboringernes biostratigrafiske inddeling er baseret på en række fossiler, som formodentlig er ukendte for de fleste danske læsere.

Da oplysningerne om arterne findes spredt $\mathrm{i}$ et stort antal afhandlinger, er der i det følgende givet kortfattede kommentarer og henvisninger for at spare danske læsere for unødigt besvær m. h.t. at finde frem til den relevante litteratur.

Beskrivelserne er ordnet alfabetisk efter slægts- og artsnavne. På tavlerne 1 til 11 er de vigtigste former endvidere afbildet. Det ligger i sagens natur, at der ved de følgende små afsnit ikke er tale om nogen udtømmende beskrivelse af de enkelte arter. De meddelte oplysninger og illustrationerne af fossilerne vil imidlertid bedre end fossillister sætte læseren i stand til at vurdere præmisserne for de stratigrafiske konklusioner.

\section{FORAMINIFERA}

\section{Ammodiscus asper (TERQUEM).}

Involutina aspera Terquem, 1864; Ellis \& Messina, 1940 ff., fig. 21a-b.

Ammodiscus asper (Terquem); Nørvang, 1957, p. 331.

Karakterer: Eksemplarerne i præparaterne fra Frederikshavn no. 2, 783-789 m $\left(2568^{\prime}-2588^{\prime}\right)$ og $849-855 \mathrm{~m}\left(2785^{\prime}-2805^{\prime}\right)$ og fra Vinding no. 1, 1458-1459 m $\left(4782^{\prime}-4788^{\prime}\right)$ er i overensstemmelse med TERQuem's beskrivelse og figurer. Formerne fra de anførte intervaller i Frederikshavn no. 2 er imidlertid opbygget af grovere sandskorn end formerne fra Vinding no. 1.

Stratigrafisk udbredelse: TERQUEM: meget almindelig i nederste Lias. NøRVANG: sjælden i Lias alpha, almindelig til talrig i Lias beta til Lias delta; Nordjylland.

Ammovertella cellensis BARTENSTEIN \& BRAND. - Tvl. 6, fig. 70.

Ammovertella cellensis BARTENSTEIN \& BRAND, 1951, p. 267-268, pl. 13, fig. 359, pl. 15 A, fig. 1-3, pl. 15 B, fig. 1-4.

Ammovertella cellensis BARTENSTEIN \& BRAND; Simon \& BARTENSTEIN, 1962, p. 254 , tab. 17 , pl. 35 , fig. 6-7. 
Karakterer: Der er nøje overensstemmelse mellem eksemplarerne fra Vedsted no. 1 og beskrivelse og figurer hos BARTENSTEIN \& BRAND, 1951.

Stratigrafisk udbredelse: BARTENSTEIN \& BRAND: meget sjælden i nedre del af mellem Valanginien; fra øverste del af mellem Valanginien (Polyptychites lag) til nederste del af øvre Valanginien (nedre Dichotomites lag) meget hyppig. I øvrige dele af øvre Valanginien mangler arten helt.

SimON \& BARTENSTEIN: Udover det foranstående findes arten sjældent i Hauterivien. Hidtil beskrevet fra Nordvesttyskland og Polen.

Angulogavelinella bettenstaedti HofKer. - Tvl. 2, fig. 17.

Angulogavelinella bettenstaedti HoFKer, 1957, p. 367, fig. 421-422.

Karakterer: God overensstemmelse med originalbeskrivelsen.

Stratigrafisk udbredelse: HoFkeR: Mellemste del af øvre Campanien til nedre Maastrichtien, Lüneburg. Forekommer ofte i store mængder.

Anomalinoides grosserugosa (GüMBEL). - Tvl. 4, fig. 34-35.

Anomalina grosserugosa (GüMBEL); FrANKE, 1927, p. 37, tvl. 4, fig. 3.

Anomalina grosserugosa (GüMBEL); Ten DAM, 1944, p. 130, tvl. 5, fig. 2.

Anomalina grosserugosa (GüMBel); Simon \& BARTEnstein, 1962, tab. 21, p. 377, tv1. 53, fig. 11a-b.

Karakterer: De to afbildede eksemplarer er sammenlignet med FrANKE's typemateriale fra Sundkrogen. Der er så stor overensstemmelse med formerne fra dybdeboringerne, at det uden tvivl er samme art. Det danske materiale afviger fra Anomalinoides danica (BROTZEN) ved en helt afrundet skalrand, hvor BROTZEN's fig. 22 (1948) viser en affladet skalrand, grænsende med skarpe rande til dorsal- og ventralsiden.

Det er sandsynligt, at de danske eksemplarer er identiske med A. grosserugosa TEN DAM.

Stratigrafisk udbredelse: Franke: Paleocæn-recent. Ten Dam: Sjælden i Paleocæn, ret hyppig i Yprésien, meget sjælden i Bartonien, Holland. Simon \& BARTENSTEIN: Meget hyppig i nedre Eocæn 3, enkeltvis i øvre Eocæn; Nordvesttyskland.

Astacolus varians (BORNEMANN).

Astacolus varians (BornemanN); NøRVANG, 1957, p. 377, fig. 123-134.

Karakterer: Formen er indgående beskrevet og afbildet hos NøRVANG, 1957. Stratigrafisk udbredelse: NøRVANG: Almindelig til hyppig i Lias alpha til Lias delta i Gassum no. 1, Frederikshavn no. 2 og Børglum no. 1. 
Asterigerina guerichi (FRANKE). - Tvl. 4, fig. 43.

Asterigerina frankei Ten DAm \& ReInHold, 1942, p. 91, pl. 7, fig. 3.

Asterigerina gürichi (FrANKe); HofKer, 1948, p. 511, tekstfig. 2a-d.

Asterigerina gürichi (Franke); Troelsen, 1954, p. 467.

Asterigerina gürichi (Franke); Simon \& Bartenstein, 1962, p. 374, tab. 21, pl. 54, fig. 20a-b, 21.

Karakterer: Det afbildede eksemplar svarer nøje til beskrivelsen hos TEN DAM \& Reinhold. På basis af et materiale på 728 eksemplarer mener Troelsen i overensstemmelse med HofKer, at $A$. frankei og $A$. guerichi bør opfattes som een art.

Stratigrafisk udbredelse: Ten DAM \& ReINHOLD: Mellem Oligocæn og mellem Miocæn, Holland. Troelsen: Mellem og øvre Oligocæn, Danmark. Simon \& BARTENSTEIN: Hyppig til dominerende i øvre del af mellem Oligocæn, i øvrigt mindre hyppig i mellem og øvre Oligocæn samt i nedre og mellem Miocæn; Nordvesttyskland. I Chattien i Molassebækkenet, Sydtyskland.

Asterigerina staeschei TEN DAm \& ReInHold, 1941. - Tvl. 5, fig. 48.

Asterigerina staeschei TEN DAM \& ReInHOLD, 1942, p. 91, pl. 7, fig. 2. Asterigerina gürichi (FRANKE); HofKer, 1948, p. 509, fig. 1-6.

Asterigerina staeschei DAM \& ReInHold; Simon \& BARTEnstein, 1962, p. 375, tab. 21, pl. 54, fig. 22, 23a-b.

Karakterer: Beskrivelse og figur hos TEN DAM \& ReINHOLd er i god overensstemmelse med det afbildede eksemplar fra Hönning. Ventralsiden er meget mere hvælvet end dorsalsiden, og marginen er forsynet med en ret smal, skarp køl. Herved adskilles den tydeligt fra $A$. guerichi, der er symmetrisk hvælvet og uden skarp køl. Det danske materiale giver anledning til at tro, at $A$. staeschei er knyttet til yngre aflejringer end $A$. guerichi.

Stratigrafisk udbredelse: Ten DAM \& ReINHOLD: Nedre og mellem Miocæn, Holland, Belgien og Nordvesttyskland. Simon \& Bartenstein: Sjælden i øvre Miocæn, særdeles talrig i mellem Miocæn, hyppig i nedre Miocæn og sjældnere i øvre Oligocæn og øvre del af mellem Oligocæn; Nordvesttyskland.

Bolivina incrassata Reuss, 1851. - Tvl. 2, fig. 18 og 21.

Bolivina incrassata Reuss; Hofker, 1957, p. 228, fig. 282-826, 291.

Bolivina incrassata gigantea Wicher; Simon \& BARTenstein, 1962, p. 312, tab. 19, pl. 51, fig. 16-17.

Karakterer: HofKeR's beskrivelse og figurer svarer nøje til de to gengivne eksemplarer. Fig. 18 repræsenterer HOFKER's $A_{2}$-generation og fig. 21 hans $\mathrm{A}_{1}$-generation, begge megalosphæriske. 
Stratigrafisk udbredelse: HofKer: Mellemste del af øvre Campanien til øvre Maastrichtien. Simon \& Bartenstein: Øverste del af øvre Campanien og Maastrichtien, i øverste del af øvre Maastrichtien er den sjælden; Nordvesttyskland.

\section{Bolivina liasica (TERqUEM).}

»Bolivina« liasica (TERQUem); NøRVANG, 1957, p. 387, fig. 182.

Bolivina liasica liasica (Terquem); Simon \& Bartenstern, 1962, p. 122, tab. 7-8, pl. 15 , fig. 71 .

Karakterer: Formerne fundet i Fjerritslev no. 1-2 og Flyvbjerg no. 1 kan uden videre henføres til samme art, som NøRVANG har truffet i boringerne Frederikshavn no. 1 og 3, Gassum no. 1 og Haldager no. 1.

Stratigrafisk udbredelse: NøRvANG: Lias gamma og Lias delta i ovennævnte boringer. Simon \& BARTENSTEIN: I det nordtyske Lias gamma og Lias delta.

Bolivinoides draco (MARSSON, 1878). - Tvl. 2, fig. 22.

Bolivinoides draco draco (Marsson); Hiltermann \& Кoch, 1950, p. 598, fig. 1, nr. 72a-b, 73a-c.

Bolivinoides draco draco (Marsson); ReIss, 1954, p. 155, pl. 29, fig. 1-3.

Bolivinoides draco (MARSSON); HofKer, 1957, p. 264, fig. 321b.

Bolivinoides draco draco (MARsson); Simon \& BARTENSTeIn, 1962, p. 318, tab. 19, pl. 46, fig. 10.

Karakterer: Det afbildede eksemplar er i overensstemmelse med beskrivelsen hos Hiltermann \& Koch og svarer til HofKer's omtale og afbildning af den megalosphæriske form.

Stratigrafisk udbredelse: HiLtermanN \& КоCH: Enkelte eksemplarer i øvre Senon 5 (=øverste Campanien), i øvrigt begrænset til øvre Senon 6-7 (= nedre Maastrichtien). Hofker: Samme udbredelse. Reiss: Hele Maastrichtien i Israel. Simon \& BARTENSTEIN: Nedre til øverste Maastrichtien; Nordvesttyskland.

\section{Bulimina asperoaculeata BROTZEN.}

Bulimina aspero-aculeata Brotzen, 1948, p. 60, pl. 6, fig. 4, pl. 10, fig. 6-7. Karakterer: Formen fra Aabenraa no. 1 er i overensstemmelse med Brotzens originalbeskrivelse. Den mangler den apikale pig ligesom formerne fra Paleocænet ved Ystad. På de ældste to til tre vindinger ses meget svage costae, der giver initialdelen en fint stribet ornamentering.

Stratigrafisk udbredelse: I Paleocæn ved Ystad, sjælden, enkeltvis forekommende ved Klagshamn, hyppig i leret ved Tygelsjö, Solnäs. BROTZEN betegner den typiske form som almindelig i det danske nedre Paleocæn. 
Bulimina elongata D'OrbignY, 1846. - Tvl. 5, fig. 46.

Bulimina elongata D'Orbigny; Ten Dam \& Reinhold, 1942, p. 80, pl. 5, fig. 11. Bulimina elongata D'OrbignY; J. IndAns, 1958, pl. 5, fig. 10, pl. 6, fig. 8, pl. 7, fig. 8, pl. 8, fig. 15 .

Bulimina elongata D'OrbignY; A. Dinesen, 1959, p. 73, pl. 4, fig. 6 (type A). Bulimina elongata Orbigny; Simon \& Bartenstein, 1962, p. 370, tab. 21, pl. 55, fig. 7-8.

Karakterer: Eksemplaret fra Tønder no. 2, vist på tavle 5, svarer til beskrivelse og illustration (fig. 6) hos A. DiNESEN af hans type A.

Stratigrafisk udbredelse: TEN DAM \& REINHOLD: Ret sjælden til ret almindelig i øre Miocæn, meget sjælden i mellem Miocæn, Holland. J. Indans: Eochatt og Neochatt D-G, Hemmoor og Reinbek-Dingden, nedre rhinske bugt. DinESEN : Mellem og øvre Oligocæn, Brejning. Simon \& Bartenstein: Øverste del af mellem Oligocæn, sjælden, op til øvre Miocæn, hyppig; Nordvesttyskland.

Bulimina midwayensis (Cushman \& PARKer). - Tvl. 6, fig. 68.

Bulimina midwayensis Cushman \& Parker; Brotzen, 1948, p. 58, pl. 10, fig. 8. Karakterer: Formerne fra Vemb no. 1 er i overensstemmelse med BROTZEN's beskrivelse og figur. Deres skal har den karakteristiske dråbeform, der fremkommer ved den store forskel i størrelse mellem kamrene i skallens ældre del og kamrene i næstsidste og navnlig sidste vinding. En dentat ornamentering ses langs randen af alle kamrene.

Bemarkninger: I Vemb no. 1 er arten fundet i stort tal i skylleprøven fra 596-599 m under terræn. Den forekommer ikke i prøverne over 596 m og kun som enkelteksemplarer i de dybereliggende prøver.

Stratigrafisk udbredelse: Brotzen: Meget sjælden i paleocænt ler ved Tygelsjö. Talrig i øverste del af det danske Paleocæn.

Bulimina trigonalis TEN DAM, 1944. - Tvl. 3, fig. 30.

Bulimina trigonalis Ten DAM, 1944, p. 112, pl. 3, fig. 16.

Bulimina trigonalis TeN DAM; HoFKer, 1951 a, p. 147, fig. 90-91.

Bulimina trigonalis Dam; Simon \& Bartenstein, 1962, p. 370, tab. 20, pl. 52, fig. 1-2.

Karakterer: Det gengivne eksemplar svarer til TEN DAM's beskrivelse, men afviger fra hans fig. 16 på følgende måde: 1) Slagelse-eksemplaret er kun svagt snoet $i$ sine ældste vindinger. 2) Den nedre kammersutur danner en opadvendt bue $\mathrm{i}$ indsnøringerne mellem de vertikale kammerrækker. 3) Initialdelens kamre er svagt ornamenterede.

Bemarkninger: I materialet kan skelnes mellem to generationer, af hvilke tvl. 3, 
fig. 30 repræsenterer den mikrosphæriske generation. Den svage ornamentering af initialdelens kamre tyder på, at $B$. trigonalis fra Slagelseboringen står $B$. aspero-aculeata BROTZEN nær (BROTZEN, 1948).

Stratigrafisk udbredelse: TEN DAM: Meget hyppig til talrig i Hollands Paleocæn. Simon \& BARTENSTEIN: Meget hyppig i Paleocæn; Nordvesttyskland.

Bulimina aff. truncanella FINLAY. - Tvl. 6, fig. 66.

Bulimina truncanella Finlay, 1940; Ellis \& Messina, 1940 ff., fig. 89, 90, 91. Karakterer: Den foreliggende form fra Vemb no. 1 er i hovedsagen i overensstemmelse med originalbeskrivelsen af $B$. truncanella. Den måler ca. 0,26 mm i længden, holotypen måler $0,27 \mathrm{~mm}$; den er tillige forsynet med tætsiddende, parallelt forløbende længderibber, som næsten helt skjuler kammersuturerne. Et større materiale er nødvendigt for at kunne fastslå identiteten mellem den danske form og holotypen fra New Zealand.

Stratigrafisk udbredelse: Holotypen er fra mellem Eocæn (nedre Bartonien). Artens vertikale udbredelse opgives fra mellem Eocæn til øvre Miocæn. I Danmark træffes formen almindeligt i Søvindmergelen.

\section{Buliminella laevis (BEISSEL). - Tvl. 2, fig. 19.}

Bulimina laevis BeIssel, 1891; Ellis \& Messina, 1940 ff., fig. 40.

Buliminella laevis (BeIsSEL); Brotzen, 1945, p. 46.

Karakterer: Sidste vindings fire kamre udgør $\frac{3}{4}$ af skallens højde, og dens største diameter er $\frac{2}{3}$ af skalhøjden. Der er god overensstemmelse med originalbeskrivelsen og BeIsSEL's fig. 40.

Stratigrafisk udbredelse: BeIsSEL: Nedre og øvre mucronata-mergel. BRotzEN: Typisk i Campanien og Maastrichtien i Höllvikenboringerne, Campanien ved Ystad og Kristianstad, almindelig i Rügens skrivekridt. Ikke fundet i Santonien.

Cancris auriculus (FICHTEL \& Moll, 1798). - Tvl. 5, fig. 45, 47.

Cancris auriculus Ficht. \& Moll; Staesche \& Hiltermann, 1940, pl. 51, fig. 1-2.

Cancris auriculus (Fichtel \& Moll); Ten Dam \& ReInhold, 1942, p. 89, pl. 6, fig. 8 .

Cancris auriculus (Fichtel \& Moll); Simon \& Bartenstein, 1962, p. 373, tab. 21, pl. 55, fig. 10-11.

Karakterer: Der er god overensstemmelse mellem Ten DAM \& ReINHOLD's beskrivelse og den danske form. Det er dog ikke nævnt, at det yngste kammer er forsynet med en læbe, der halvvejs dækker umbilicus og delvis skjuler næst- 
sidste og trediesidste kamres umbilicalende. En tilsvarende læbe kan ses på pl. 51, fig. 1 hos Staesche \& Hiltermann (1940).

Stratigrafisk udbredelse: StAesche \& Hiltermann: Øvre Miocæn; Nordvesttyskland. Ten Dam \& ReINHOLd: Meget sjælden i Pliocæn og i øvre Miocæn $(1 \%)$, ret sjælden i øvre Mellemiocæn ( $12 \%)$, ret hyppig i nedre Mellemmiocæn $(16 \%)$ og meget sjælden i øvre Oligocæn $(1 \%)$; Holland. Meget typisk for Mellemmiocæn i Nordvesteuropa. Simon \& BartensteIn: Ret sjælden i øvre Oligocæn og mellem Miocæn, ret hyppig i øvre Miocæn; Nordvesttyskland.

Ceratobulimina contraria (Reuss, 1851). - Tvl. 4, fig. 42.

Ceratobulimina contraria Reuss; Staesche \& Hiltermann, 1940, pl. 50, fig. 11, 12, non fig. 10, 13, 14.

Ceratobulimina contraria (Reuss); Ten DAM \& ReInHold, 1942, p. 92, pl. 6, fig. $9 \mathrm{a}-\mathrm{c}$.

Ceratobulimina (Ceratobulimina) contraria (Reuss); Troelsen, 1954, p. 456, pl. 10, fig. 5, 13.

Ceratobulimina contraria (Reuss); Simon \& BARTEnstein, 1962, p. 375, tab. 21, pl. 54, fig. 10-12.

Karakterer: Der er ikke fundet anledning til ændring af beskrivelsen hos TeN DAM \& ReInHOLD, jvf. TROELSEN.

Stratigrafisk udbredelse: StAesche \& Hiltermann. Øvre Oligocæn, Reitbrook I. Ten DAM \& ReINHold : Øvre Miocæn ( $1 \%$ ), mellem Miocæn (2-8\%), Oligocæn $(1 \%)$; Holland. Troelsen: Mellem Oligocæn, Faarup, 206 eksemplarer. Simon \& BARTENSTEIN: Hyppig i Miocæn og mellem Oligocæn, sjælden i det øvrige Oligocæn; Nordvesttyskland.

Ceratocancris haueri (D'ORBIGNY). - Tvl. 5, fig. 52.

Rotalina hauerii D'OrbignY, 1846, p. 151, pl. 7, fig. 22, 23, 24.

Ceratobulimina haueri (D’Orbigny); Cushman, 1927, p. 175, pl. 29, fig. 6-10. Ceratobulimina contraria Reuss; Staesche \& Hiltermann, 1940, pl. 50, fig. 13, 14, non. fig. 11, 12.

Ceratobulimina haueri (D'ORBIGNY); MARKs, 1951, p. 67.

Ceratobulimina (Ceratocancris) haueri (D'OrbignY); Troelsen, 1954, p. 457, pl. 10, fig. 4, 6 .

Karakterer: Det afbildede eksemplar stemmer overens med beskrivelsen hos P. MARKs. Den accessoriske interne skillevæg (TroelsEN, 1954) er ikke bemærket, da dissektion ikke er foretaget.

Stratigrafisk udbredelse: StAesche \& Hiltermann: Øvre Miocæn; Nordvesttyskland. Troelsen: Miocæn; Østrig og Ungarn. 
Cibicides formosus Brotzen. - Tvl. 6, fig. 62.

Cibicides formosa Brotzen, 1945, p. 55, pl. 2, fig. 3.

Cibicides formosus Brotzen; Simon \& Bartenstein, 1962, p. 319, tab. 19, pl. 46, fig. 1.

Karakterer: Spiralsiden stærkt hvælvet, umbilicalsiden flad. De øvrige karakterer er også i nøje overensstemmelse med beskrivelser og figurer hos BROTZEN og hos Simon \& Bartenstein.

Stratigrafisk udbredelse: BRotzen: I Höllviken no. 1-2 kun i Gault-Cenomanien, sjælden. I Tormarpkonglomeratet ikke ualmindelig i Albien-Cenomanien. Simon \& BARTENSTEIn: Ikke hyppig i Cenomanien, forekommer enkeltvis i nedre Cenomanien og nedre Turonien; Nordvesttyskland.

Cibicides cf. pseudoungerianus (Cushman). - Tvl. 5, fig. 54.

Truncatulina pseudoungeriana CusHman, 1922, p. 97, fig. 9.

Cibicides pseudoungeriana (Cushman); Dinesen, 1959, p. 85, pl. 7, fig. 2a-c.

Karakterer: Der er god overensstemmelse med CuSHMAN's og med DinESEN's beskrivelser. Det afbildede eksemplar afviger dog med én karakter: Marginen er afrundet i modsætning til den subcarinate margin på CusHMAN's figur 9 og DINESEN's figur 2c. Der er grund til at mene, at afvigelsen ligger inden for artens variation.

Stratigrafisk udbredelse: Cushman: Recent. Dinesen: Oligocæn og Miocæn. Ten Dam \& Reinhold, 1941: Øvre Oligocæn, mellem Miocæn og Scaldisien; Holland.

Cibicides sulzensis (HerrmanN). - Tvl. 4, fig. 39.

Cibicides sulzensis (HerrmanN); Batjes, 1958, p. 149, pl. 9, fig. 5.

Cibicides sulzensis (HerrmanN); KAAsschieter, 1961, p. 223, pl. 13, fig. 11. Karakterer: Der er god overensstemmelse med bemærkningerne hos BATJES og KAASSCHIETER. Det danske eksemplar er groft poret på dorsal- og ventralsiden, ligesom det vises på figurerne af de belgiske former.

Stratigrafisk udbredelse: BATJEs: Øvre Oligocæn, Berg-sand og Boom-ler; Belgien. KaAsschieter: Nedre og øvre Eocæn, Jeper-ler, n. Panisel, Lede-sand, Wemmel-sand, Asse-ler; Belgien.

Cibicides voltzianus (D'OrbignY). - Tvl. 3, fig. 28.

Rotalina voltziana D’Orbigny, 1840, p. 31, pl. 2, fig. 32-34; Ellis \& Messina, 1940, ff.

Discorbina bembix MARsson, 1878, p. 167, pl. 5, fig. 37a-d. 
Cibicides voltziana (D'Orbigny); Brotzen, 1940, p. 24, fig. 7, 3a-c.

Karakterer: Den afbildede form er i overensstemmelse med originaldiagnosen og med BRotzen's figur 7,3. MARSSON's beskrivelse og figur viser tydeligt, at hans Discorbina bembix er synonym med Slagelse-eksemplaret.

Stratigrafisk udbredelse: Brotzen: Campanien til grænsen Danien-Paleocæn. Når et maksimum i øvre Mellemdanien.

Clavulina parisiensis D'Orbigny. - Tvl. 4, fig. 40.

Clavulina parisiensis D’OrbignY, 1826, p. 268, modèles, no. 66, $3^{\text {me }}$ livr.; Ellis \& Messina, $1940 \mathrm{ff}$.

Clavulina parisiensis D'Orbigny; KAASSChIETER, 1961, p. 144, pl. 1, fig. 27-28. Karakterer: Materialet er i overensstemmelse med originalbeskrivelsen og KAASSCHIETER's figurer.

Stratigrafisk udbredelse: D'OrbIGNY: Lutetien, Pariserbasinet. KAASSCHIETER: Lede formation, nedre Asse formation i øvre Eocæn; Belgien.

Conorotalites aptiensis (BettenstAedt). - Tvl. 6, fig. 64.

Globorotalites bartensteini aptiensis Bettenstaedt, 1952, p. 282, pl. 3, fig. 32 pl. 4, fig. 59-72.

Conorotalites aptiensis (BetTenstaedT); Simon \& Bartenstein, 1962, p. 278, tab. 18, pl. 37, fig. 3 tekst-fig. 22.

Karakterer: Den afbildede form fra Hönning no. 1 har en spidskonisk umbilicalside og plan til svagt konveks spiralside. Den hører derfor til variantgruppe $\mathrm{m}$ eller $\mathrm{n}$ af de Conorotalites-arter, som er variationsstatistisk undersøgt af Bettenstaedt (1958), se Simon \& Bartenstein, 1952, tekstfig. 22, no. 5, p. $276-277$.

Stratigrafisk udbredelse: Simon \& BARTENSTEIn: Øverste del af øvre Barrêmien til nederste del af nedre Albien, ikke sjælden, stedvis hyppig; Nordvesttyskland, Sydtyskland, Østrig, Frankrig, Sicilien og Trinidad.

Conorotalites intercedens (BettenstaedT). - Tvl. 1, fig. 9.

Globorotalites bartensteini BetTENSTAEDT, 1952, p. 277, tvl. 3, fig. 30-32, tvl. 4, fig. 33-72.

Conorotalites intercedens (Bettenstaedt); Simon \& Bartenstein, 1962, p. 277, tab. 18, tvl. 37, fig. 2, tekstfig. 22.

Karakterer: Sidste vinding har 5 kamre, lobat, kantet margin, dyb umbilicus. Talrige tydelige porer i skaloverfladen. God overensstemmelse med artsdiagnosen. 
Bemarkninger: Det afbildede eksemplar fra Vemb no. 1 har meget stor lighed med paratypoid fig. 53 (G. bartensteini intercedens) hos BetTEnstaedT, 1952. Stratigrafisk udbredelse: BetTENSTAEDT: nedre Barrêmien (pugio-zonen), særlig hyppig i mellem Barrêmien, mindre hyppig i øvre Barrêmien og Aptien. Ender i nederste nedre Albien (omkr. nolani-zonen). G. bartensteini intercedens: M1. til øvre Barrêmien (denckmanni-zonen til bidentatum-zonen). Simon \& BARTENSTEIN: denckmanni-zonen (mellem Barrêmien) til bidentatum-zonen (øverste del af øvre Barrêmien) mest hyppig.

\section{Dentalina matutina D'ORBIGNY}

Dentalina matutina matutina D'OrbIGNY; NøRVANG, 1957, p. 361, fig. 88, 90-93. Karakterer: Formerne fra de nyere dybdeboringer (1957-1959) er i overensstemmelse med beskrivelsen og figurerne hos NøRVANG.

Stratigrafisk udbredelse: BARTENSTEIN \& BRAND, 1937: sjælden i Lias alpha, hyppig i Lias beta, ikke sjælden i Lias gamma og Lias delta, Nordvesttyskland. BARNARD, 1950: Meget talrig i semicostatum-zonen, forekommer fra selve den øvre grænse af bucklandi-zonen til den øverste del af raricostatum-zonen.

»Discorbis« binkhorsti (Reuss). - Tvl. 3, fig. 25.

Rosalina binkhorsti Reuss, 1862, tvl. 2, fig. 3a-c.

Conorbina binkhorsti (Reuss); BROTZEN, 1936, p. 145.

Discorbis binkhorsti (Reuss); BROTZEN, 1940, p. 32.

Mississippina binkhorsti (REUss); HoFKeR, 1958, p. 101, fig. 1-6.

Bemoerkninger: I litteraturen har denne art været henført til mange forskellige slægter (HoFKeR, 1958). Den benævnes »Discorbis«, da den sandsynligvis er identisk med Discorbis binkhorsti Brotzen, 1940. Arten afviger væsentligt fra Mississippina monsouri Howe og kan derfor ikke henføres til Mississippina.

Stratigrafisk udbredelse: Reuss: Kreidetuff, Maastricht; Holland. Brotzen (1940): Sjælden i Maastrichtien, hyppig i zoner i mellem Danien og særlig hyppig i nederste øvre Danien.

Elphidium clavatum Cushman, emend. Loeblich \& TAPpan. - Tvl. 5, fig. 56. Elphidium incertum (Williamson) var. clavatum Cushman, 1939, p. 57, tvl. 16, fig. 1-2.

Elphidium incertum var. clavatum CUSHMAN; VoORTHUYSEN, 1950a, p. 42, tvl. 4, fig. 1a-b.

Elphidium clavatum Cushman, emend. Loeblich \& TAPpan, 1953, p. 98, 101, 102, fig. 8-10; Ellis \& Messina, 1940 ff. 
Karakterer: Det afbildede eksemplar fra Slagelse no. 1 er i god overensstemmelse med typebeskrivelsen af 1953. Den er mere sammentrykt end typeeksemplaret, fig. 8b, en afvigelse, der muligvis ligger inden for artens variation.

Stratigrafisk udbredelse: CusHman: Recent, LOEBLICH \& TAPPAN: Recent, nordlige Alaska. VoORTHUYSEn: En af de hyppigste former i marint Kvartær; Holland. I Danmark er den fundet i de fleste marine kvartæraflejringer ofte som dominerende art.

Epistomina caracolla (Roemer). - Tvl. 1, fig. 7.

Epistomina caracolla caracolla (RoEMER); BARTENSTEIN \& BRAND, 1951, p. 326, tvl. 11, fig. 323, tvl. 12A, fig. 330.

Epistomina caracolla (Roem.); SzTejn, 1957, p. 248, tvl. 10, fig. 93.

Epistomina (Höglundina) caracolla caracolla (Roemer); Simon \& BARTEnstein, 1962, p. 260, tab. 17, pl. 35, fig. 13.

Karakterer: Beskrivelse og figur hos SZTEJN er i god overensstemmelse med Vedstedeksemplaret. Yngste kammer mangler. Septalforamen en spidsvinklet trekant, hvor den spidse vinkel når tæt ind mod foregående vindings margin. Stratigrafisk udbredelse: SzTEJN: Øvre Valanginien og Hauterivien, centrale Polen. Bartenstein \& Brand: Øvre Valanginien, nedre og øvre Hauterivien, uddøende i Barrêmien, Nordvesttyskland. Simon \& Bartenstein: Mellemste Dichotomites-lag (øvre Valanginien) til nedre Barrêmien, mest hyppig. Kosmopolitisk form i nedre del af nedre Kridt.

Epistomina elegans (D'OrbignY). - Tvl. 5, fig. 55.

Epistomina elegans (D'Orbigny, 1826); Ten Dam \& Reinhold, 1942, p. 89, tvl. 6, fig. 10 .

Epistomina elegans (D'Orbigny); BAtJes, 1958, p. 155, tvl. 10, fig. 2.

Epistomina partschiana (Orbigny, 1846); Simon \& Bartenstein, 1962, p. 374, tab. 21, pl. 55 fig. 3-4.

Karakterer: Der er god overensstemmelse med beskrivelsen hos TEN DAM \& Reinhold og hos Simon \& Bartenstein.

Bemarkninger: SimON \& BARTENSTEIN betragter E. elegans som synonym til E. partschiana.

Stratigrafisk udbredelse: TEN DAM \& ReINHOLD: Mellem Oligocæn - mellem Miocæn, typisk for hollandsk septarieler. BAtJEs: Øvre Oligocæn og mellem Miocæn. Simon \& Bartenstein: Mellem Oligocæn, til øvre Miocæn, mest hyppig; Nordvesttyskland. 
Epistomina polypioides (EICHENBERG). - Tvl. 6, fig. 59.

Epistomina (Brotzenia) spinulifera polypioides (EICHENBERG); Simon \& BARTENSTEIN, 1962, p. 288, tab. 18, pl. 41, fig. 2.

Karakterer: I god overensstemmelse med beskrivelse og figur hos SimON \& BARTENSTEIN.

Stratigrafisk udbredelse: Øverste del af øvre Aptien til nederste del af øvre Albien; Nordvesttyskland.

Epistomina spinulifera (Reuss). - Tvl. 1, fig. 8.

Rotalia spinulifera Reuss, 1862, p. 93, tvl. 13, fig. 3-5.

Epistomina spinulifera (ReUss); TEN DAM, 1948, p. 169.

Epistomina spinulifera (Reuss); BetTENSTAedt, 1952, p. 266.

Epistomina (Brotzenia) spinulifera spinulifera (REUss); Simon \& BARTENSTEIN, 1962 , p. 281 , tab. 18 , pl. 41, fig. 4.

Karakterer: I originaldiagnosen og i TEN DAM's beskrivelse opfattes de fortykkede suturer med småtakket rand som særlig karakteristisk for arten. Det afbildede eksemplar (tvl. 1, fig. 8) måler 0,4 mm langs største diameter, hvorimod SimON \& BARTENSTEIN anfører $1,02 \mathrm{~mm}$ langs største diameter på deres eksemplar (tvl. 41, fig. 4).

Stratigrafisk udbredelse: Reuss: Hyppigste art i Gault, Folkestone. Ten DAm: Yderst talrig i Albien, Holland, Tyskland og England. Bettenstaedt: Lokalt hyppig i øvre Barrêmien (bidentatum-zone), ikke sjælden i øvre Barrêmien (rude-zone), sjælden i mellem Barrêmien. Simon \& Bartenstein: Mellem Barrêmien til øvre Albien. I Nordvesttyskland kun mellem til øvre Barrêmien, sædvanligvis sjælden og kun lokalt forekommende. Dog stedvis hyppig i Crioceras bidentatum-zonen, øverste del af øvre Barrêmien.

Eponides candidulus (Schwager). - Tvl. 4, fig. 36.

Eponides candidulus (Schwager); Ten Dam, 1944, p. 119, tvl. 4, fig. 4.

Karakterer: Der er god overensstemmelse med beskrivelse og figur hos TEN DAM.

Stratigrafisk udbredelse: Schwager: Eocæn, Mokkatam-Stufe, Ægypten. TeN DAM: sjælden, stedvis hyppigere, Bartonien; Holland.

Gaudryina hiltermanni MEISL. - Tvl. 4, fig. 37.

Clavulina aff. szaboi Staesche \& Hiltermann, 1940, p. 16, pl. 38, fig. 3. Gaudryina hiltermanni Meisl; Simon \& Bartenstein, 1962, p. 362, tab. 20, pl. 53, fig. 6 . 
Karakterer: Formen står Staesche \& Hiltermann's fig. 3 meget nær, idet den består af en serie yngre kamre i triserial følge, efterfulgt af en kort biserial del, der afsluttes med eet uniserialt kammer. Det triseriale afsnit er trekantet i tværsnit, det har svagt konkave sider og i nogle eksemplarer er det svagt spiralsnoet. Den biseriale del udgøres af få, oftest kun to kamre med afrundet tværsnit.

Stratigrafisk udbredelse: Staesche \& Hiltermann: nedre Eocæn 3. I de danske boringer er formen karakteristisk i dele af det nedre, røde, plastiske Røsnæs-ler. Simon \& Bartenstein: Meget hyppig i nedre Eocæn 3, enkeltvis persisterende til øvre Eocæn; Nordvesttyskland.

Gavelinopsis cenomanica (BRotZeN). - Tvl. 1, fig. 11.

Cibicidoides (Cibicides) cenomanica Brotzen, 1945, p. 54, pl. 2, fig. 2.

Gavelinopsis cenomanica (Brotzen); Simon \& BARTENSTEIN, 1962, p. 318, pl. 48, fig. 1.

Karakterer: Det afbildede eksemplar fra Åbenråboringen svarer nøje til originalbeskrivelsen. Den fortykkede spiralsutur, som iflg. Brotzen gør arten let genkendelig, er tydeligt til stede på eksemplarerne fra danske dybdeboringer. Stratigrafisk udbredelse: Brotzen: Cenomanien og Gault i Höllviken I og II. Simon \& BARTENSTEIN: enkeltvis i øvre Albien, hyppigere i Cenomanien og i nedre Turonien; Nordvesttyskland.

Gavelinopsis ef. involuta (Reuss). - Tvl. 3, fig. 27.

Rotalia involuta Reuss var.; Reuss, 1861, p. 313, pl. 2, fig. 4a-b. Gavelinopsis involuta (ReUss); HoFKeR, 1956, p. 101, fig. 17A, B, C.

Karakterer: Overensstemmelse med beskrivelser hos ReUss og HOFKER med een afvigelse: Foreliggende eksemplars periferi er ikke lobulat. Grove porer findes både på spiral- og umbilicalsiden (jvf. HofKer 1960, p. 241).

Stratigrafisk udbredelse: HoFKeR: Danien og øverste skrivekridt (Pseudotextularia-zone) i Danmark (1959).

Bemarkninger: Muligvis identisk med Cibicides $c f$. constricta (REUSS), BROTZEN 1940, der betegnes som karakteristisk i øvre Danien.

\section{Geinitzina tenera praepupa NøRVANG.}

Geinitzina tenera praepupa NøRVANG, 1957, p. 338, fig. 30-31.

Karakterer: Se Nørvang, 1957 (Originaldiagnose).

Bemarkninger: Formen er opført ved Haldager no. 1, 1403-1521 m, jvf. NøRVANG, 1957, p. 330.

$8^{*}$ 
Stratigrafisk udbredelse: NørvaNG: Almindelig i Lias beta, Gassum no. 1, sjælden i Lias gamma; Nordjylland.

Geinitzina tenera pupoides NøRVANG.

Geinitzina tenera pupoides NøRvaNG, 1957, p. 338, fig. 25-29.

Karakterer: Se NøRVANG, 1957 (Originaldiagnose).

Stratigrafisk udbredelse: NøRvANG: Almindelig i Lias beta til Lias gamma; Danmark.

\section{Geinitzina tenera tenera (BORNEMANN).}

Gienitzina tenera tenera (BornemANN); NøRVANG, 1957, p. 336, fig. 18-23.

Karakterer: Se NøRVANG, 1957.

Bemarkninger: Formen, der er opført som Geinitzina tenera i intervallet 13761899 m under Vedsted no. 1, skal sandsynligvis henføres til G. tenera tenera. Stratigrafisk udbredelse: NørvaNG: Sjælden i Lias gamma i Danmark.

\section{Geinitzina tenera tenuistriata NøRVANG.}

Geinitzina tenera tenuistriata NøRVANG, 1957, p. 334, fig. 13, 16, 17, 24.

Karakterer: Se NøRVANG, 1957 (Originaldiagnose).

Stratigrafisk udbredelse: NøRVANG : almindelig i Lias alpha i Danmark, desuden sjælden i Lias beta i Gassum no. 1. Sandsynligvis begrænset til nedre Lias.

Globigerina yeguaensis Weinzierl \& Applin, 1929. - Tvl. 4, fig. 38.

Globigerina yeguaensis Weinzierl \& Applin; BergGren, 1960, p. 74, pl. 2, fig. 1-4, pl. 3, fig. 1-3, pl. 4, fig. 1-2, pl. 8, fig. 1-5, tekstfig. 11.

Karakterer: I nøje overensstemmelse med den meget fyldige beskrivelse hos BERGGREN.

Stratigrafisk udbredelse: BergGren: Røsnæsler, Røgle Klint, nedre Eocæn, Danmark. Katarinenhof på Fehmarns østkyst, nedre Eocæn 3; Tyskland.

Globorotalites michelinianus (D'ORBIGNY). - Tvl. 1, fig. 12.

Rotalia micheliniana (D'ORB.); Franke, 1928, p. 188, tvl. 17, fig. 11.

Globorotalites michelinianus (D'OrBIGNY); HOFKer, 1957, p. 405, fig. 460-466. Karakterer: HOFKER's beskrivelse og figurer er i god overensstemmelse med det afbildede eksemplar. Den interne opbygning er ikke undersøgt.

Stratigrafisk udbredelse: HoFKER: Nedre Campanien. 
Haplophragmoides canariensis (D'OrBIGNY). - Tvl. 6, fig. 61.

Haplophragmoides canariensis (D'ORBIGNY); BARTENSTEIN \& BRAND, 1937, p. 189, pl. 10, fig. 46, pl. 11A, fig. 20.

Karakterer: Den afbildede form fra Vemb no. 1 er i god overensstemmelse med beskrivelse og figurer hos BARTENSTEIN \& BRAND.

Stratigrafisk udbredelse: BARTENSTEIN \& BRAND: Hele Dogger, sjælden; Nordvesttyskland.

Lagena hauteriviana hauteriviana BARTENSTEIN \& BRAND. - Tvl. 6, fig. 67.

Lagena hauteriviana hauteriviana BARTENSTEIN \& BRAND, 1951, p. 317, pl. 10, fig. 277-278.

Lagena hauteriviana hauteriviana BARTENSTEIN \& BRAND, 1951; SIMON \& Bartenstein, 1962, tab. 17, p. 265, pl. 35, fig. 18.

Karakterer: Skallen kugleformet, glat, med to diametralt stillede, oftest ulige lange mundingsrør. De øvrige karakterer svarer ligeledes nøje til originalbeskrivelsen og figurerne hos BARTENSTEIN \& BRAND, 1951.

Stratigrafisk udbredelse: BARTENSTEIN \& BRAND: Hyppig fra øverste del af nedre Hauterivien (bivirgatus-zonen) til mellemste del af øvre Hauterivien (hildesiense-zonen), mangler helt, eller er sjælden, i det øvrige Nedre Kridt, Nordvesttyskland. SimON \& BARTENSTEIn: Hauterivien, særlig nedre Hauterivien, hyppig. Oftest sjælden i øvre Hauterivien. Meget sjælden i små eksemplarer i mellem Barrêmien; Nordvesttyskland.

\section{Lenticulina acutiangulata (TERQUEM).}

Lenticulina acutiangulata (Terquem); NørVANG, 1957, p. 383, fig. 177-178.

Lenticulina acutiangulata (Terquem); Simon \& BARTENSTEIn, 1962, p. 118, tab. 7, pl. 15, fig. 65 .

Karakterer: Se NøRvang, 1957.

Stratigrafisk udbredelse: NøRVANG: Lias gamma i Frederikshavn no. 1 og Lias delta i Gassum no. 1. Simon \& Bartenstein: Øvre Lias gamma og Lias delta; Nordtyskland.

Lenticulina eichenbergi BARTENSTEIN \& BRAND. - Tvl. 1, fig. 6.

Lenticulina (Lenticulina) eichenbergi BARTENSTEIN \& BRAND, 1951, p. 285, tvl. 5, fig. 118-119.

Karakterer: En Lenticulina med limbate suturer, der mere eller mindre regelmæssigt er opløst i enkeltstående knuder på begge skalsider. Dette karakteristiske træk er tillige med øvrige karakterer overensstemmende med originalbeskrivelsen.

Stratigrafisk udbredelse: BARTENSTEIN \& BRAND: Øvre Valanginien og Hauterivien. 


\section{Lenticulina gottingensis (BORNEMANN).}

Lenticulina gottingensis (BORNEMANN); NøRVANG, 1957, p. 382, fig. 153-170. Karakterer: Se NøRVANG, 1957.

Stratigrafisk udbredelse: NøRvANG: Hyppig i Lias beta, Gassum no. 1; almindelig til sjælden i Lias gamma i Børglum no. 1, Frederikshavn no. 1 og 2, Gassum no. 1; almindelig i Lias delta i Gassum no. 1.

Lenticulina d'orbignyi (ROEMER). - Tvl. 1, fig. 5.

Cristellaria (Lenticulina) d'orbignyi (ROEMER); BARTENSTEIN \& BRAND, 1937, p. 178, tvl. 6, fig. 37, tvl. 9, fig. 56 .

Lenticulina (Lenticulina) d'orbignyi (Roemer); Simon \& BARTEnstein, 1962, p. 118 , tab. 7 og 8, tvl. 15, fig. 66.

Karakterer: Hvert kammer på overfladen dækket af parallele, aksialt orienterede, ækvidistante ribber. Hver ribbe møder suturlisten ud for et mellemrum mellem det næstfølgende kammers længderibber. Suturlisterne får derved et ret regelmæssigt zig-zagformet forløb.

Stratigrafisk udbredelse: ROEMER: Dogger, Nordtyskland. BARTENSTEIN \& Brand: Lias zeta (Jurensis-lag) - Dogger beta (Ludwigia-lag). Simon \& BArTenSTEIN: Hyppig i tysk Lias zeta og Dogger alpha.

\section{Marginulina prima D'ORBIGNY.}

Marglinuina prima D'ORBIGNY; BARTENSTEIn \& BRAND, 1937, p. 161, pl. 2B, fig. 26, pl. 3, fig. 39-40, pl. 4, fig. 60, pl. 5, fig. 46.

Marginulina prima D'OrbignY; Simon \& BARTenstein, 1962, p. 120, tab. 7, 8, pl. 15, fig. 68.

Karakterer: Beskrivelsen hos SIMON \& BARTENSTEIN er så rummelig, at formerne fra Flyvbjerg no. 1, Fjerritslev no. 2, Vedsted no. 1, Vemb no. 1 og Horsens no. 1 ligger inden for artens variation.

Stratigrafisk udbredelse: Simon \& BARTENSTEIN: Lias alpha 1 til øvre del af Lias delta i Tyskland og desuden i nederste og øverste del af Lias epsilon i Sydtyskland.

\section{Marginulina prima praerugosa NøRVANG.}

Marginulina prima praerugosa NøRVANG, 1957, p. 369, fig. 96.

Karakterer: Se NøRvANG, 1957 (Originaldiagnose).

Stratigrafisk udbredelse: Lias alpha til Lias gamma i Gassum no. 1, Lias alpha til Lias beta i Vejrum no. 1., Lias alpha i Vinding no. 1. 
Marginulina prima prima D'ORBIGNY.

Marginulina prima prima D’OrBIGNY; NøRVANG, 1957, p. 367, fig. 98, 99, 103, 104.

Karakterer: Se Nørvang, 1957.

Stratigrafisk udbredelse: Lias gamma i Frederikshavn no. 1 og Børglum no. 1, Lias delta i Gassum no. 1.

\section{Marginulina prima rugosa BORNEMANN.}

Marginulina prima rugosa Bornemann; NøRVAnG, 1957, p. 368, fig. 97.

Karakterer: Se Nørvang, 1957.

Stratigrafisk udbredelse: Lias gamma, almindelig til hyppig i Børglum no. 1, Frederikshavn no. 1 og 2 og Gassum no. 1. Sjælden i Lias beta og Lias delta i Gassum no. 1 .

Marginulina radiata TERQUEM.

Marginulina radiata Terquem; Nørvang, 1957, p. 364, fig. 94-95.

Karakterer: Se NøRvANG, 1957.

Stratigrafisk udbredelse: NøRvANG: Almindelig i Lias alpha, Gassum no. 1.

\section{Marginulinopsis matutina (D'ORBIGNY).}

Marginulinopsis matutina (D'OrbIGNY); NøRVANG, 1957, p. 374, fig. 115, 117. Karakterer: Se Nørvang, 1957.

Stratigrafisk udbredelse: Almindelig til sjælden i Lias alpha, Gassum no. 1 og Vejrum no. 1.

Marginulinopsis ef. oldenburgensis BARTENSTEIN \& BRAND. - Tvl. 6, fig. 69.

Lenticulina (Marginulinopsis) oldenburgensis BARTENSTEIN \& BRAND, 1951, p. 288, pl. 6, fig. 140 .

Karakterer: Den afbildede form fra Vedsted no. 1, 801-806 m, er i flere henseender i overensstemmelse med originalbeskrivelsen: Dens længde er 0,5 mm som holotypen, og ligesom hos den består den evolutte del af 3 kamre, der er adskilt af indsænkede suturer. Den afviger kun på eet punkt: Originalbeskrivelsen nævner langstrakte ornamenter (»Leisteneckchen «), tætsiddende langs den proximale kant af hvert kammer. Vedsted-eksemplaret har på samme steder en enkelt- eller dobbeltrække afrundede knuder. Om denne afvigelse falder uden 
for artens variation, kan kun afgøres, når et større materiale kan skaffes til veje. Bemarkninger: BARTENSTEIN \& BRAND omtaler en form, som HECHT, 1938, (pl. 23, fig. 84-86) publicerede under betegnelsen Marginulina D 26 fra øvre Hauterivien. Marginulina D 26 afviger både fra Marginulinopsis oldenburgensis og fra Vedstedformen, idet den er udstyret med talrige, mere uregelmæssigt arrangerede lister og pigge. De er dog tydeligt grupperet fortrinsvis langs de enkelte kamres proximale kant, og de tre former må derfor anses for at være nært beslægtede.

Stratigrafisk udbredelse: BARTENSTEIN \& BRAND: Mellem Valanginien og øvre Valanginien 1 (nedre Dichotomites-lag); Nordvesttyskland.

Marginulinopsis radiata (FRANKE non TERQUEM).

Marginulinopsis radiata (Franke non Terquem); NørVAng, 1957, p. 371, fig. 105, 107.

Karakterer: Se NøRvANG, 1957.

Stratigrafisk udbredelse: Nørvang: Almindelig i nedre del af Lias beta, Gassum no. 1, sjælden i Lias gamma til Lias delta, Gassum no. 1. Desuden er den sjælden i Lias beta i Vejrum no. 1 og i Lias gamma i Frederikshavn no. 2.

\section{Marssonella oxycona (Reuss).}

Marssonella oxycona (Reuss); HoFker, 1957, p. 85, fig. 86-90.

Karakterer: HOFKeR giver en udførlig beskrivelse ledsaget af 14 tegninger af denne art.

Stratigrafisk udbredelse: Hofker: Øvre del af nedre Campanien til øvre Maastrichtien i Nordvesttyskland og Holland.

Neoflabellina rugosa (D'OrbignY). - Tvl. 1, fig. 14.

Neoflabellina rugosa (D’Orbigny); Hiltermann \& Koch, 1956, p. 36, Abb. 4, fig. 7-9.

Neoflabellina rugosa (D'Orbigny); Hiltermann \& Кoch, 1957, p. 274, Abb. 2 , tvl. 7-14.

Neoflabellina rugosa (D'Orbigny); Simon \& Bartenstein, 1962, p. 308, tab. 19, tvl. 48, fig. 13-15.

Karakterer: Den foreliggende form ligger inden for artens variation, som beskrevet i monografien af 1957.

Stratigrafisk udbredelse: Hiltermann \& Koch: Campanien. Simon \& BartenSTEIN: I hele Campanien; Nordvesttyskland. 
Nodosaria metensis TERQUEM.

Nodosaria metensis Terquem; NørVAng, 1957, p. 352, fig. 72.

Karakterer: Se Nørvang, 1957.

Stratigrafisk udbredelse: Nørvang, 1957, p. 75: Sjælden i Lias beta i Gassum no. 1 og Vejrum no. 1; p. 36 (skema): Almindelig i Lias alpha, Gassum no. 1. Fig. 72 viser arten fra Gassum no. 1, 4950'-4970' = Lias alpha.

\section{Nodosaria torsicostata TeN DAM. - Tvl. 3, fig. 32-33.}

Nodosaria torsicostata Ten DAM, 1944, p. 96, tvl. 2, fig. 16.

Nodosaria torsicostata DAm; Simon \& BARTENSTEIN, 1962, p. 364, tab. 20, tvl. 52, fig. 12.

Karakterer: De enkelte kamre meget store (ca. $1 \mathrm{~mm}$ i diameter) med kraftige længderibber, der forløber i skrå retning i de dybe indsnøringer mellem kamrene. God overensstemmelse med originalbeskrivelsen.

Bemarkninger: Fig. 32 og 33 viser samme enkeltkammer i to forskellige optiske planer for at vise de grove ribbers forløb.

Stratigrafisk udbredelse: TeN DAm: Sjælden til ret sjælden i Paleocæn; Holland. Simon \& Bartenstein: Hyppigst i Paleocæn, sjældnere i nedre Eocæn 3; Nordvesttyskland.

Nonion soldanii (D'OrbignY). - Tvl. 5, fig. 49.

Nonion soldanii (D’Orbigny); Cushman, 1939, p. 13, pl. 3, fig. 11.

Nonion soldanii (D'Orbigny); Ten Dam \& Reinhold, 1942, p. 76, pl. 5, fig. 1. Nonion soldanii (D'Orbigny); Dinesen, 1959, p. 89.

Karakterer: Der er god overensstemmelse med beskrivelsen hos CusHMAN og hos Ten Dam \& ReInhold. Det foreliggende eksemplar har ni kamre i sidste vinding.

Stratigrafisk udbredelse: Cushman: Miocæn i Østrig, i Ungarn, på Sardinien og i Ægypten. Ten DAM \& ReINHold: Ret sjælden i mellem Miocæn og nedre Øvremiocæn; Holland. DinesEn: Mellem Oligocæn - nedre Miocæn, enkelte eksemplarer.

Osangularia lens Brotzen. - Tvl. 3, fig. 29.

Osangularia lens Brotzen, 1940, p. 30, fig. 8, nr. 1.

Parella lens (Brotzen); Brotzen, 1945, p. 56, fig. 10, pl. 2, fig. 7.

Osangularia lens Brotzen; Hofker, 1957, p. 390, fig. 434.

Karakterer: Den foreliggende form svarer nøje til BRoTzEN's klare beskrivelse. Stratigrafisk udbredelse: BRotzen, 1940: Øvre Maastrichtien. Nedre og mellem Danien meget hyppig. Brotzen, 1945: Karakteristisk for Danien; Sverige og 
Danmark, talrig. Sjælden i øvre Maastrichtien. Hofker: Maastrichtien i Lüneburg, Gross-Hehlen, Oldenbüttel, Hemmoor, Basbeck; Nordvesttyskland, og øvre Gulpenkridt; Syd-Limburg, Holland. Kun i nedre $\mathrm{M}_{\mathrm{b}}$ i Tuffkridt fra Maastricht.

Planularia crepidularis (RoEMER). - Tvl. 1, fig. 4.

Cristellaria (Astacolus) tricarinella Reuss, 1863; BARTENSTEIN \& BRAND, 1937, p. 173, pl. 13, fig. 35, pl. 14B, fig. 13, pl. 15A, fig. 33, pl. 15C, fig. 18.

Planularia tricarinella (Reuss); BRAND, 1949, pl. 13, fig. 1, pl. 14, fig. 25.

Lenticulina (Planularia) crepidularis (Roemer, 1842); SIMON \& BARTENSTEIn, 1962 , p. 260 , tab. 17 , pl. 36, fig. 7.

Karakterer: Det afbildede eksemplar fra Fjerritslev no. 1 er i god overensstemmelse med beskrivelsen hos Simon \& Bartenstein, 1962.

Stratigrafisk udbredelse: Reuss: Nedre Kridt, øvre Hils, lerbænk med Crioceras emerici, mellemste Kridt; nedre Gault, Speeton Clay. Bartenstein \& BRAnD, Dogger epsilon (Parkinsoni) - Malm alpha (Heersumer lag), sjælden. Simon \& Bartenstein: Øvre Dogger, marin Malm, Valanginien til Aptien. I Nordvesttysklands nedre Kridt: Mellemste Dichotomites-lag (øvre Valanginien) til nedre Barrêmien ikke sjælden til hyppig, i mellemste Barrêmien og øvre Aptien kun meget sjælden og lokalt forekommende.

\section{Planularia inaequistriata (TERQUEM).}

Planularia inaequistriata (Terquem); NørVANG, 1957, p. 380, fig. 148, 149.

Karakterer: Formerne, der er fundet i de nyere boringer (Horsens no. 1, Slagelse no. 1 og Vemb no. 1), er i nøje overensstemmelse med beskrivelsen og figurerne hos NøRVANG, 1957.

Stratigrafisk udbredelse: NøRvANG: Sjælden i Lias alpha i Gassum no. 1, Vejrum no. 1 og Vinding no. 1. Almindelig i Lias alpha i Nordvesteuropa.

\section{Planularia stilla (TERQUEM).}

Cristellaria (Planularia) stilla Terquem; Franke, 1936, p. 96, pl. 9, fig. 26.

Planularia stilla (TERQuem); NøRVANG, 1957, p. 379, fig. 136-147.

Karakterer: Formerne fra de nyere boringer (Horsens no. 1 og Slagelse no. 1) viser en variation, der falder inden for arten, som den opfattes af NøRVANG ifølge tolv figurer. En marginal køl er sjældent tydeligt til stede.

Stratigrafisk udbredelse: NøRVANG: almindelig til hyppig i Lias alpha, sjælden i Lias beta, Gassum no. 1. 
Pseudoglandulina vulgata pupoides (BORNEMANN).

Pseudoglandulina vulgata pupoides (BORnEMANN); NørVANG, 1957, p. 359.

Karakterer: Se NøRVANG, 1957.

Stratigrafisk udbredelse: NøRvANG: Almindelig i Lias delta i Gassum no. 1.

Pseudotextularia elegans (RzенAк). - Tvl. 2, fig. 24.

Pseudotextularia elegans (Rzehak); Brotzen, 1945, p. 45, pl. 1, fig. 4-5.

Pseudotextularia varians (elegans) RzEHAK; Hofker, 1957, p. 422, fig. 478i, $\mathrm{k}, 1, \mathrm{~m}$.

Pseudotextularia elegans (Rzehak); Simon \& Bartenstein, 1962, p. 337, tab. 19, pl. 46, fig. 11-12.

Karakterer: Der henvises til HoFKER's beskrivelse. Den foreliggende form svarer til HoFKer's »b-form «. HoFker anser $P$. elegans for apogam.

Stratigrafisk udbredelse: BROTZEN: Karakteristisk for øverste 10-15 m af Maastrichtien umiddelbart under Danien i boringer ved Landskrona, Lund, Malmö og Trelleborg. Yderligere i Jylland og Sjælland. Hofker: Øverste Maastrichtien; Holland og Nordvesttyskland. Simon \& BARTENSTEIN: I borealt Kridt i øverste del af øvre Maastrichtien (casimirovensis zonen). »Pseudotextularia-niveauet « (WICHER, 1953).

Pseudovalvulineria ef. lorneiana (D'OrbignY). - Tvl. 2, fig. 15.

Rosalina lorneiana D'OrbignY, 1840, p. 36, pl. 3, fig. 20, 21, 22; Ellis \& Messina, $1940 \mathrm{ff}$.

Anomalina lorneiana (D’ORB.); Franke, 1928, p. 181, pl. 17, fig. 3.

Pseudovalvulineria lorneiana (D'Orbigny); BRotzen, 1942, p. 20, fig. 6 no. 7. Karakterer: Der er god overensstemmelse med beskrivelser og figurer hos de tre forfattere, dog med een afvigelse: dorsalsiden er konveks på eksemplarerne fra danske dybdeboringer; de beskrevne formers dorsalside er konkav undtagen hos BROTZEN (1942).

Stratigrafisk udbredelse: Franke: Cenomanien-Senonien. I danske boringer findes den op til øvre Campanien.

Pullenia sphaeroides (D'OrbignY). - Tvl. 5, fig. 50.

Pullenia sphaeroides (D’Orbigny); Ten Dam \& Reinhold, 1942, p. 94. Pullenia sphaeroides (D'OrbigNy); Dinesen, 1959, p. 80, pl. 5, fig. 8. Karakterer: Det afbildede eksemplar svarer til beskrivelsen hos TEN DAM \& REINHOLD. Det er næsten kugleformet som DinESEN's form med $4 \frac{1}{2}$ kammer i sidste vinding. 
Stratigrafisk udbredelse: Ten DAM \& ReINHOLD: Meget sjælden i hele Miocæn og Oligocæn, Holland. DiNESEN: Enkelte eksemplarer, mellem Oligocæn.

Pyramidina curvisuturata Brotzen. - Tvl. 3, fig. 26.

Pyramidina curvisuturata Brotzen, 1940, p. 29, fig. 6: 4a, b, c.

Karakterer: Den foreliggende form svarer nøje til beskrivelse og figur hos BRotzen.

Stratigrafisk udbredelse: Begrænset til øvre Danien, særlig hyppig i den nederste del.

Reinholdella cf. dreheri (BARTENSTEIN). Tvl. 1, fig. 2-3.

Discorbis dreheri BARTEnstein; BARTENSTEIN \& BRAND, 1937, p. 192, pl. 6, fig. 45, pl. 18, fig. 42, pl. 10, fig. 47.

Reinholdella dreheri (BARTENSTEIN); HoFKer, 1952, p. 20, fig. 7-10.

Karakterer: Den danske form er i overensstemmelse med beskrivelserne hos Bartenstein og hos Ten Dam, som den citeres af Hofker. Den interne struktur er ikke undersøgt.

Stratigrafisk udbredelse: BARTEnsteIn: Lias zeta (Jurensis-lag), Dogger alpha (Opalinus-lag) og beta (Ludwigia-lag), ikke sjælden.

Reophax cf. metensis FranKe. - Tvl. 6, fig. 58.

Reophax metensis Franke, 1936, p. 19, pl. 1, fig. 17a-b.

Reophax metensis Franke; Bartenstein \& Brand, 1937, p. 133, pl. 10, fig. 8, pl. 13, fig. 1a-b, 4.

Karakterer: Den afbildede form fra Vemb no. 1 er morfologisk i overensstemmelse med FrankE's originalbeskrivelse. Der indgår dog grove partikler i skalmaterialet i den foreliggende form. Der er også stor lighed med figurerne hos BARTENSTEIN \& BRAND, hvor det dog er vanskeligt at afgøre byggematerialets grovhed. Disse forfattere giver ingen beskrivelse af arten.

Stratigrafisk udbredelse: Franke: Lothringen, Lias delta, Margaritatus lag, ikke sjælden. BARTENSTEIN \& BRAND: Meget sjælden i hele Dogger; Nordvesttyskland.

Reophax multilocularis HAEUSLER. - Tvl. 1, fig. 1.

Reophax multilocularis Haeusler, 1883, p. 26; Ellis \& Messina, 1940, ff. Reophax multilocularis HAEUSLER; BARTENSTEIN \& BRAND, 1937, p. 133, pl. 5, fig. 8, pl. 8, fig. 8, pl. 10, fig. 9, pl. 11A, fig. 5, pl. 15A, fig. 4, pl. 15C, fig. 2. Karakterer: I overensstemmelse med beskrivelse og figurer hos BARTENSTEIN \& BRAND.

Stratigrafisk udbredelse: HAEUSLER: Nedre Malm (A. transversarius-zone). BARTENSTEIN \& BRAND: Lias alpha-delta, hele Dogger. 
Reussella pseudospinulosa Troelsen MS., 1945. - Tvl. 2, fig. 16.

Reussella pseudospinulosa Troelsen, 1937, p. 261 (nomen nudum)

Reussella pseudospinulosa Troelsen MS., 1945; Brotzen, 1945, p. 46, pl.1, fig. 6.

Reussella pseudospinulosa Troelsen (Brotzen 1945); Hofker, 1957, p. 212, fig. 259, 260.

Karakterer: Det afbildede eksemplar er i god overensstemmelse med HOFKER's beskrivelse og figur $259 \mathrm{~d}$, e, f, af den megalosphæriske generation.

Stratigrafisk udbredelse: Troelsen 1937: Skrivekridt, Bostrichoceras-zone, nedre Constrictus-zone. Brotzen: Santonien, meget sjælden, hyppig i Campanien, sjælden i nedre Maastrichtien. Hofker: Meget karakteristisk for nedre Campanien og nedre del af øvre Campanien; Nordvesttyskland.

Saracenaria bronnii (ROEMER). Tvl. 1, fig. 10.

Lenticulina (Saracenaria) bronnii (Roemer); Simon \& Bartenstern, 1962, p. 257, tab. 17, pl. 36, fig. 3, pl. 38, fig. 3 .

Karakterer: Den afbildede form fra Horsens no. 1 er i overensstemmelse med beskrivelsen hos Simon \& BARTEnstein. Mundingspartiet er beskadiget, så aperturets karakter ikke kan iagttages. Eksemplaret repræsenterer sandsynligvis en form, der er intermediær mellem de to former, der er afbildet hos Simon \& BARTENSTEIN (loc. cit.).

Stratigrafisk udbredelse: SIMON \& BARTENSTEIN: Almindeligt forekommende i $ø v r e$ Valanginien til nedre Aptien, hyppig i øvre del af øvre Hauterivien. I øvre Aptien og nedre del af nedre Albien meget sjælden og samtidig afvigende ved uregelmæssigheder i kammerformen i skallens langstrakte del.

\section{Saracenaria sublaevis FRANKE.}

Saracenaria sublaevis Franke; NørVANG, 1957, p. 381, fig. 151.

Lenticulina (Saracenaria) sublaevis (Franke); Simon \& BARTENSTEIN, 1962, p. 119 , tab. 7-8, pl. 15, fig. 67.

Karakterer: Formerne fra de nyere boringer er i overensstemmelse med figur og beskrivelse hos Nørvang og hos Simon \& BARTENSTEIn.

Stratigrafisk udbredelse: Nørvang: Almindelig i Lias delta, Gassum. Simon \& BARTENSTEIN: I Nordtyskland i Lias delta 2 spinatus-zonen og øverst i Lias delta 1b; i Sydtyskland i hele Lias delta undtagen Pleuroceras bechteri-zonen.

Sphaeroidina variabilis Reuss, 1851. - Tvl. 5, fig. 51.

Sphaeroidina variabilis Reuss; Ten DAm \& ReInhold, 1942, p. 95, pl. 7, fig. 5. Sphaeroidina variabilis Reuss; DINESEN, 1959, p. 81, pl. 6, fig. 2. 
Karakterer: Det afbildede eksemplar fra Vemb svarer til beskrivelsen hos TEN DAM og ReINHOld og hos Dinesen.

Stratigrafisk udbredelse: TeN DAM \& ReINHOLD: Sjælden i øvre Oligocæn, stedvis hyppigere i mellem Oligocæn; Holland. Dinesen: Øvre Oligocæn, ni eksemplarer.

\section{Spiroplectammina carinata (D'ORBIGNY). - Tvl. 4, fig. 44.}

Spiroplectammina carinata (D'ORBIGNY); TEN DAM \& ReINHOLD, 1942, p. 42, pl. 1, fig. 2-3, tekstfig. 2.

Spiroplectammina carinata (D’ORBIGNY); TEN DAM, 1944, p. 81.

Spiroplectammina carinata (ORbigny); Simon \& Bartenstein, 1962, p. 361, tab. 21, pl. 54, fig. 5, 6a-b, 7, 8 .

Karakterer: Der er god overensstemmelse med beskrivelsen af den megalosphære generation hos Ten DAM \& ReINHold, 1942, og hos Simon \& BARTENSTEIN.

Stratigrafisk udbredelse: TEN DAM \& ReINHOLD: Regelmæssig, hyppig til sjælden, hele Oligocæn og mellem Miocæn, Holland. Ten DAM, 1944: Af og til fundet i flere eksemplarer i Bartonien; Holland. Simon \& Bartenstein: Hyppig til dominerende i Oligocæn og i nedre og mellem Miocæn, sjælden i øverste del af mellem Eocæn og i øvre Eocæn; Nordvesttyskland.

Spiroplectammina spectabilis (GRZYBOWSKI). - Tvl. 3, fig. 31.

Spiroplectammina spectabilis (GrzyBovski); Ten DAm, 1944, p. 81, pl. 2, fig. 6-7.

Spiroplectammina spectabilis (Grzybowski); Simon \& BARTEnStern, 1962, p. 361, tab. 20, pl. 52, fig. 7-9.

Karakterer: Der er god overensstemmelse med beskrivelse og figur (fig. 6) af den megalosphæriske form hos TEN DAM og med den udførlige beskrivelse samt figurerne hos Simon \& BARTEnSTEIN.

Stratigrafisk udbredelse: TEN DAM: Ikke sjælden i Paleocæn i Holland, især i brakvandslag. Sjælden i brakt Yprésien; Holland. Simon \& Bartenstein: Oftest ikke sjælden i Paleocæn og nedre Eocæn 1, 2 og 3 i Nordvesttyskland.

Stensioeina exsculpta (Reuss). - Tvl. 1, fig. 13.

Stensiöina exsculpta (Reuss); Brotzen, 1936, p. 165, pl. 11, fig. 8. Stensiöina exsculpta (Reuss); HofKer, 1957, p. 348, fig. 398, 399, 400.

Stensiöina exsculpta (Reuss); Simon \& BARTENStein, 1962, p. 325, tab. 19, pl. 49, fig. 15-18. 
Karakterer: Dorsalsiden konveks med ophøjet spiralsutur; i overensstemmelse med beskrivelserne hos Brotzen, Hofker og Simon \& BARtenstein.

Stratigrafisk udbredelse: Brotzen, 1945: Santonien og Emscherien; Höllviken. Hofker: Mellem Santonien til nederste del af nedre Campanien. Simon \& Bartenstein: Santonien til nedre del af øvre Campanien, hyppig til dominerende i nedre Campanien.

Stensioeina exsculpta gracilis BROTZEN. - Tv1. 6, fig. 63.

Stensiöina exsculpta gracilis Brotzen, 1945, p. 52, pl. 1, fig. 15.

Stensiöina gracilis (Brotzen); Hofker, 1957, p. 347, fig. 396-397.

Stensiöina exsculpta gracilis Brotzen; Simon \& Bartenstein, 1962, p. 324, tab. 19, p1. 49, fig. 13-14.

Karakterer: Det afbildede eksemplar fra Harte no. 1 er i god overensstemmelse med beskrivelser og figurer i de ovennævnte publikationer. Umbilicus er dækket af kridtslam og derfor ikke nærmere undersøgt.

Stratigrafisk udbredelse: Brotzen: Almindelig i Santonien og Emscherien, sjælden i nedre Campanien. Hofker: Fra nedre grænse af mellemste Santonien til nederste del af nedre Campanien; Nordvesttyskland. Simon \& Bartenstein: I Coniacien og Santonien, hyppig i øvre Coniacien og i nedre Santonien.

Stensioeina pommerana BrotZEN. - Tvl. 2, fig. 20, 23.

Stensiöina pommerana BRotZEN, 1936, p. 166.

Stensiöina pommerana Brotzen; Brotzen, 1945, p. 51, pl. 1, fig. 14.

Stensiöina pommerana Brotzen; Simon \& Bartenstein, 1962, p. 327, tab. 19 , pl. 51, fig. 11-13.

Karakterer: De to afbildede former er i god overensstemmelse med beskrivelserne hos Brotzen (1936 og 1945) og hos Simon \& BARTENSTEIN.

Stratigrafisk udbredelse: Brotzen, 1945: Meget sjælden i Santonien, talrig i Campanien og Maastrichtien, Höllviken. - 1936: Mucronatasenonien i Pommern (Rügen, Finkenwalde), i Skåne (Kvarnby) og i Frankrig (Meudon). Simon \& BARTENSTEIN: I det boreale kridt enkeltvis i øvre del af nedre Campanien, hyppigere i øvre Campanien og Maastrichtien. Mangler helt i nedre del af øvre Maastrichtien, bortset fra sjældne enkeltfund.

\section{Stensioeina praeexsculpta (Keller). - Tvl. 6, fig. 65.}

Stensiöina prae-exsculpta (KelleR); Brotzen, 1945, p. 52, pl. 1, fig. 16-17. Stensiöina prae-exsculpta (KELLER); HofKer, 1957, p. 345, fig. 394-395. Stensiöina praeexsculpta (Keller); Simon \& BARTEnstein, 1962, p. 323, tab. 19, pl. 49, fig. 10-11. 
Karakterer: Det afbildede eksemplar fra Vemb no. 1 er i god overensstemmelse med beskrivelser og figurer i de tre ovennævnte publikationer. Der er en jævnt afrundet overgang mellem den svagt konvekse spiralside og marginen.

Stratigrafisk udbredelse: Brotzen: Turonien og Emscherien i Höllviken, udelukkende Turonien i Donetzbassinet; Hofker: Nederste del af nedre Santonien til mellemste Santonien; Nordvesttyskland; Simon \& BARTEnsteIn: Øvre Turonien til mellemste Santonien, hyppig i Coniacien; Tyskland.

Streblus beccarii (LINNÉ). - Tvl. 5, fig. 57.

Rotalia beccarii (Linneus); Ten Dam \& Reinhold, 1941, p. 58, tvl. 4, fig. 7-9, tvl. 6, fig. 12.

Streblus beccarii (Linné); LANGE, 1956, p. 79, tvl. 10, fig. 13.

Rotalia beccarii (Linnaeus); Simon \& BARTEnstein, 1962, p. 372, tab. 21, tvl. 55, fig. 18a-c.

Karakterer: Det afbildede eksemplar er i god overensstemmelse med beskrivelse og figurer hos Ten Dam \& ReInhold og fig. 13 hos LANGe.

Bemarkninger: Som hos LANGE er der afstået fra en henføring til subgenus, før detaillerede undersøgelser foreligger.

Stratigrafisk udbredelse: TEN DAM \& ReINHOLD: Pliocæn og Pleistocæn, Holland. Lange: Recent, Skagerak og Kattegat. Simon \& Bartenstein: I Nordvesttyskland hyppig i øvre Miocæn. Fra Pliocæn til nu hører denne formrige og kosmopolitiske art til de hyppigst forekommende foraminiferer i marine og brakke lavtvandsområder.

Triplasia emslandensis emslandensis BARTENSTEIN \& BRAND. - Tvl. 6, fig. 71.

Triplasia emslandensis emslandensis BARTENSTEIN \& BRAND, 1951, p. 274, pl. 3, fig. 65-67.

Karakterer: Den afbildede form fra Vedsted no. 1 svarer nøje til beskrivelsen og figurerne hos BARTENSTEIN \& BRAND, 1951.

Stratigrafisk udbredelse: (op. cit.) øvre Valanginien 3 til øvre Hauterivien, sjælden til ikke sjælden; i nedre noricus-lag dog stedvis hyppig.

Uvigerina hosiusi Ten Dam \& ReINHold. - Tvl. 5, fig. 53.

Uvigerina hosiusi Ten Dam \& Reinhold, 1941; Ten DAm \& Reinhold, 1942, p. 84 , pl. 6, fig. $1-3$, pl. 9 , fig. 4 , tekstfig. 7 .

Uvigerina hosiusi DAM \& ReInHOLD; Simon \& BARTENSTEIN, 1962, p. 371, tab. 21, pl. 55, fig. 12-13.

Karakterer: God overensstemmelse med beskrivelsen af den megalosphæriske 
form, Ten Dam \& Reinhold, 1942, og med beskrivelsen hos Simon \& BartenSTEIN.

Stratigrafisk udbredelse: TEN DAM \& REINHOLD: Karakterart for Dingdener Stufe, mellem Miocæn, Holland, hyppig.

Vaginulina harpa RoEMER. - Tvl. 6, fig. 60.

Vaginulina harpa Roemer; BARTENSTEIn \& BRAND, 1937, p. 163, pl. 14B, fig. 7, pl. 14C, fig. 10, pl. 15A, fig. 24a-b, pl. 15C, fig. 12a-d.

Karakterer: Der er god overensstemmelse med beskrivelse og figurer hos BARTENSTEIN \& BRAND, 1937.

Stratigrafisk udbredelse: BARTENSTEIN \& BRAND: Dogger epsilon (Aspidoideslag) til Malm alpha (Heersumer lag), sjælden; Nordvesttyskland.

\section{Vaginulina ef. inconstans (TERQUEM).}

Vaginulina inconstans (TERquem); BARTENSTEIN \& BRAND, 1937, p. 164, pl. 10, fig. 26.

Bemarkninger: Formen rapporteret 16. november 1951 af Robert Weynschenk fra kærne no. 11 (2810'-2830') i Uglev no. 1. Præparatet er ikke til stede.

Stratigrafisk udbredelse: BARTENSTEIN \& BRAND: Nedre Dogger, (Opalinus-lag og Ludwigia-lag), meget sjælden; Nordvesttyskland.

\section{Vaginulina listi (BORNEMANN).}

Vaginulina listi (Bornemann); NørVAnG, 1957, p. 370, fig. 119.

Karakterer: Se NøRVANG, 1957.

Stratigrafisk udbredelse: NøRVANG: Almindelig i Lias beta i Gassum no. 1 og almindelig i Lias gamma i Frederikshavn no. 2.

Vaginulinopsis decorata (REUSs). - Tvl. 4, fig. 41.

Cristellaria decorata Reuss, 1855; Staesche \& Hiltermann, 1940, p. 16, pl. 42, fig. 4.

Vaginulinopsis decorata (Reuss); TeN DAM, 1944, p. 101, pl. 2, fig. 12-13.

Lenticulina (Vaginulinopsis) decorata (Reuss); Simon \& BARTENSTEIN, 1962, p. 366 , tab. 20 , pl. 53 , fig. $13-15$.

Karakterer: Der er god overensstemmelse mellem foreliggende form og beskrivelsen hos Ten Dam og figur 4 hos Staesche \& Hiltermann. De hollandske afbildninger (fig. 12-13) er noget afvigende, men også det danske materiale giver indtryk af ret stor variation af denne særdeles karakteristiske form. 
Stratigrafisk udbredelse: Staesche \& Hiltermann: Hyppig i nedre Eocæn 3, sjældnere i øvre Eocæn i Nordvesttyskland. TEN DAM: Hyppig i Yprésien, stedvis sjælden i Lutétien og Bartonien; Holland. Simon \& BARTENSTEIN: I Nordvesttyskland mest hyppig til dominerende i nedre Eocæn 3, mellem Eocæn og øvre Eocæn. I øvrige Nordeuropa ikke sjælden i Yprésien, Lutétien og Bartonien.

\section{GRAPTOLITHINA}

Monograptus crispus LAPWORTH. - Tvl. 11, fig. 113.

Monograptus crispus LAPWORTH 1876, p. 503, pl. 20, fig. 7.

Monograptus crispus LAPWORTH; 1918, Elles \& WoOD, p. 456, pl. 45, fig. 6.

Karakterer: Rhabdosomet har form som et spørgsmålstegn. Thekerne udadbøjede og spiralsnoede som følge af dorsalvæggens stærke udvikling (lobate theker). Thekerne når ikke ind over hinanden. Eksemplarerne fra Slagelse svarer godt til ELLES \& WoOD's beskrivelse.

Stratigrafisk udbredelse: Skotland og Wales: Monograptus crispus zonen, øvre del af Llandovery Series (Gala-Tarannon beds). Skåne: Rastrites skifer.

\section{PELECYPODA}

Astarte ef. ryensis TroEDSSON.

Astarte ryensis TroedsSON; 1951, p. 171, pl. 11, fig. 11-13.

Karakterer: Subtriangulær Astarte, hvælvet, med få »tilvækstringe« og fin koncentrisk stribning. Eksemplarerne fra Rødby no. 1 har op til 10 kraftige koncentriske ribber på skallens ældste del og nærmer sig derved $A$. oerbyensis Troedsson (1951, p. 171, pl. 11, fig. 6-9).

Stratigrafisk udbredelse: Katslösa stadiet: Grammatodon cypriniformis og Pseudopecten aequivalvis zonerne (nedre Pliensbachien = Lias gamma), Skåne.

Astarte cf. subdepressa Blake \& Hudleston. - Tvl. 7, fig. 79.

Astarte subdepressa Blake \& Hudleston; 1877, p. 393, pl. 14, fig. 10 (dårlig figur).

Astarte subdepressa Blake \& Hudleston; Arkell, VI, 1934, p. 235, pl. 33, fig. 1-9.

Karakterer: Holotypen er afbildet hos Arkell (fig. 1). Et typisk træk er, at der findes ca. 40 eller flere, fine, koncentriske ribber på skallen indtil en afstand af ca. $20 \mathrm{~mm}$ fra umbo. I øvrigt henvises til ARKELL's beskrivelse m.h.t. nærstående former fra Englands jura. Skallen fra Børglum ret defekt.

Stratigrafisk udbredelse: ARKelL: Hambleton Oolite Series (sandsynligvis 
Cardioceras cordatum zonen), Osmington Oolite Series (Perisphinctes martelli zonen) og Trigonia clavellata beds, endvidere i Glos Oolite Series (Perisphinctes antecedens zonen). Biozonerne iflg. Arkell, 1933.

Astarte Sæmanni DE LORIOL. - Tvl. 7, fig. 80-82.

Astarte Scrmanni De Loriol; de Loriol \& Pellat, 1866, p. 68, pl. 6, fig. 9. Astarte Scemanni de Loriol; Ethel G. Skeat \& Victor Madsen, 1898, p. 123, pl. 3, fig. 2.

Karakterer: Denne meget karakteristiske og hyppige art er kommenteret, delvis beskrevet og udmærket afbildet hos SKeAt og MADSEN. Der er god overensstemmelse mellem det af disse to forfattere beskrevne materiale og skallerne i kernen fra Børglumboringen.

Stratigrafisk udbredelse: Loriol \& Pellat: Marnes à Perna Bouchardi, Portlandien; Boulogne s.-m., Frankrig. Skeat \& Madsen: Nedre Portland i Wiltshire (Portland sand) og Buckinghamshire (Hartwell clay) i England. Samme forfattere: Løs blok nr. 30, Hirtshals, der er korreleret med nedre Portland.

Buchia Fischeri (D'Orbigny), - Tvl. 7, fig. 72; tvl. 8, fig. 86.

Avicula Fischerianum D'Orbigny; 1845 in Murchison, Verneyl \& Keyserling. II, p. 472, pl. 41, fig. 8-10.

Aucella Fischeri D'Orb.; PAvlow, 1907, p. 58, pl. 4, fig. 15-19.

Karakterer: Skallen kun lidt konveks, udtrukket skævt nedad-bagud. Venstreskallen med forholdsvis lille umbo, der er drejet lidt fremad. Højreskallen betydeligt mindre konveks end venstreskallen. Bageste øre svagt udviklet, lille byssusøre. Umbonalvinkelen ca. $80^{\circ}$. Koncentriske folder almindelig. Materialet fra Børglum og Haldager svarer godt til PAvLows beskrivelse og afbildninger.

Stratigrafisk udbredelse: PAvLow: Begynder at optræde i Virgatites virgatus zonen (mellem Portlandien = øvre del af nedre Volga-etage). Hyppig i Aquilonien $(\varnothing v r e$ Portlandien $=\varnothing v r e$ Volga-etage, bl. a. i Craspedites subditus zonen jfr. von Bubnoff, 1952 og ArKell, 1956).

Camptonectes lens (J. Sowerby). - Tvl. 8, fig. 87-88.

Pecten lens J. Sowerby; 1818, p. 3, pl. 205, fig. 2-3.

Camptonectes lens (J. Sowerby); Arkell, II, 1930, p. 94, pl. 7, fig. 1, pl. 9, fig. 4-7.

Karakterer: M.h.t. afgrænsningen af denne art har der hersket en del uklarhed, som er fjernet ved ARKelL's undersøgelse. Typisk for $C$. lens er det omtrent 
cirkelrunde omrids, en fin punkteret ornamentering, radiale punkterede striber på højreskallens bageste øre og mangel på lameller både på venstreskallens forreste øre og højreskallens bageste øre. Skallerne fra Børglum og Haldager svarer godt til ARKELL's beskrivelse og afbildninger.

Stratigrafisk udbredelse: Arkell: Lower Calcareous Grit (Cardioceras cordatum zonen), Berkshire Oolite Series og Osmington Oolite Series (begge: Perisphinctes martelli zonen) og Glos Oolite Series (Perisphinctes antecedens zonen, svarende til nederste del af serien). Biozonerne iflg. Arkell, 1933.

\section{Chlamys interpunctata TROEDSSON.}

Chlamys interpunctata Troedsson; 1951, p. 214. pl. 20, fig. 18.

Karakterer: Apicalvinkel ca. $100^{\circ}$. Forreste øre med tæt stribning. Skaloverfladen med 20-22 svage radialribber og tæt stribning af tilvækstlinier. Desuden meget fin skulptur af punkterede radiallinier og koncentriske linier. (Arten er rapporteret fra Rødby no. 1 men har ikke kunnet identificeres i kernestykkerne, som er overladt D.G.U.)

Stratigrafisk udbredelse: Katslösa stadiet: Ptychomphalus cfr. expansus zonen (nedre Pliensbachien $=$ Lias gamma), Skåne.

\section{Cucullaea contracta PhilLiPs. - Tvl. 7, fig. 74.}

Cuccullaea contracta PhiLlips; 1829 pl. 3, fig. 30.

Cuccullaea contracta Phillips. Arkell, I, 1929 p. 43, pl. 1, fig. 14-15.

Karakterer: En meget variabel form med fremstående umboner og en ornamentering bestående af fine radialstriber, der udvikler sig til radialribber på forreste del af skallen. Oftest kort forende og skævt udtrukket bagende. Skallen fra Børglum meget defekt.

Stratigrafisk udbredelse: ARKELL: øvre Oxfordien, nedre Kimeridgien og Portlandien; Frankrig.

Berkshire Oolite Series (Perisphinctes martelli zonen), Osmington Oolite Series (Perisphinctes martelli og P. antecedens zonerne) og Trigonia clavellata Beds (Perisphinctes antecedens zonen); England.

\section{Eotrapezium hyllingense TROEDSSON.}

Eotrapezium hyllingense Troedsson; 1951, p. 136, pl. 3, fig. 1.

Karakterer: Ækvivalv, subcirkulær; umbo lidt foran midten. Overflade med tilvækstlinier. Størrelsesorden: 5 mm. Enkelte defekte skaller fra Rødby no. 1 henføres til denne art. Synes at svare godt til Troedsson's afbildning og beskrivelse.

Stratigrafisk udbredelse: TroEDSSON: Rhaet over nedre kullag, Skåne. 


\section{Grammatodon cypriniformis (LUNDGREN).}

Cucullaea cypriniformis LUNDGREN; 1879, p. 19, fig. 29, 35.

Macrodon cypriniformis LundGR.; Malling \& Grönwall, 1909, p. 283.

Grammatodon cypriniformis (LundGRen); Troedsson, 1951, p. 154, pl. 17, fig. $1-15$; pl. 18, fig. 1.

Karakterer: Venstreskallen forsynet med 3 til 5 relativt stærke ribber foran forreste $\mathrm{k} \varnothing \mathrm{l}$ og få ribber ved og på bageste køl. Tynde, vertikale ribber på umbo. Højreskallen dækket med tynde, tætliggende ribber. To til tre ribber foran umbo kan være kraftigere udviklet end de øvrige. Ret stærk variation. Arten har ikke kunnet identificeres i materialet fra Rødby no. 1, som er overladt D.G.U., eksemplaret kan være gået tabt.

Stratigrafisk udbredelse: MALLING \& GRÖNWALL: Androgynoceras centaurus zonen, nedre Pliensbachien (Lias gamma), Bornholm. Troedsson: Grammatodon cypriniformis zonen Katslösa stadiet, nedre Pliensbachien (Lias gamma), Skåne.

\section{Isognomon promytiloides (ARKELL).}

Isognomon promytiloides ArKelL, 1933, V. p. 207, pl. 27, fig. 2, 3, $3 \mathrm{a}$.

Karakterer: Нøj, skæv skal, moderat hvælvet i umbonal og midterpartiet. Umbo spids. Skallens forrand stærkt konkav under umbo. Vinklen mellem dorsalrand og linien der forbinder umbo og det mest fremspringende punkt på forranden ca. $60-70^{\circ}$. Smalle ligamentgruber af omtrent samme bredde som deres mellemrum. Eksemplaret fra Gassum er et brudstykke, hvis bageste del mangler. Men det svarer godt til ArKeLL's beskrivelse.

Stratigrafisk udbredelse: Øverste del af Oxford clay og Lower Calcareous Grit, England (ArKell). Nøjagtig zone i Oxford clay ukendt. Lower Calcareous Grit svarer til Cardioceras cordatum zonen.

\section{Lima (Plagiostoma) mutabilis ArKeLL.}

Lima (Plagiostoma) mutabilis Arkell; 1926, p. 201, pl. 20, fig. 1-3.

Lima (Plagiostoma) mutabilis Arkell; Arkell, III, 1931, p. 130, pl. 12, fig. 4-5; pl. 14, fig. 4.

Karakterer: Smalle radialgruber adskilt ved indtil 85-100 flade ribber. Ingen punktering i radialgruberne. I øvrigt en ret stor art (ARKELL nævner en maksimallængde på $120 \mathrm{~mm}$ ). Stor variation m.h.t. radialskulpturen, idet der oftest findes et glat midterparti på skallen. Eksemplaret fra Gassum er i god overensstemmelse med afbildninger og beskrivelse hos ARKELL.

Stratigrafisk udbredelse: Arkell: Berkshire Oolite Series og Osmington Series (begge: Perisphinctes martelli zonen); England. Clynelish Quarry sandstone og Ardassie limestone (Cardioceras zonen). 


\section{Liogryphaea ef. arcuata (LAMARCK).}

Gryphaea arcuata LAMARCK; 1802, p. 398.

Gryphaea arcuata LAMARCK; SKEAT \& MAdSEN, p. 78.

Liogryphaea arcuata (LAMARCK); 1951, TroedSSON, p. 226, pl. 1, pl. 7, fig. 1-6, pl. 8, fig. 1-10.

Karakterer: Meget varieret skal. Højreskal ret stærkt indrullet. Analsinus antydet af tilvækstlinierne. Ingen dorsoventralfure i skallens bageste del. Højreskal omtrent cirkelrund. Ret velbevaret højreskal fra Gassum.

Stratigrafisk udbredelse: Troedsson: Nedre lias i Vesteuropa, Schlotheimia angulata zonen til øvre Sinemurien.

\section{Liostrea cf. irregularis MÜNSTER.}

Liostrea irregularis MüNSTER; SCHÄFLE, p. 16, pl. 1, fig. 1-14.

Karakterer: Glat ostreide uden særligt fremhævede karakteristika. Materialet fra Rødby no. 1 henføres kun med forbehold til denne art p.gr.a. manglende bestemmelseskriterier.

Stratigrafisk udbredelse: Nedre lias. Troedsson: Helsingborg stadiet i Skåne (Hettangien, lias alpha ${ }_{1}-$ alpha $_{2}$ ).

\section{Modiola minuta (GoldFuss).}

Mytilus minutus GoldFuss; 1837, p. 173, pl. 130, fig. 6.

Modiola minuta GoldF. Troedsson, 1951, p. 140, pl. 3, fig. 10-11.

Karakterer: Goldfuss' afhandling har ikke været tilgængelig og TROEDsson har ikke fremhævet artskriterierne. I kernematerialet fra Rødby no. 1 findes i intervallet $556-557 \mathrm{~m}$ talrige små Modiola, som med forbehold henføres til denne art.

Stratigrafisk udbredelse: Troedsson: Rhaet (Pteria contorta zonen) og nedre lias. Skåne: Rhaet.

Ostrea (Liostrea) delta Sмітн. - Tvl. 8, fig. 84-85.

Ostrea delta William SMith 1817, p. 18.

Ostrea deltoidea Sow.; Schmidt 1905, p. 160, pl. 5, fig. 7-12, pl. 6, fig. 1.

Ostrea (Liostrea) delta SмIтH; 1932 ARkell p. 149, pl. 16, fig. 2-4, pl. 15, fig. 6 og pl. 14, fig. 6 .

Karakterer: Næsten ækvivalv, men usymmetrisk. Posterodorsalrand med dyb sinus, hvorved skallen synes bøjet bagud. Lukkemuskelar nedenfor denne sinus. Overfladen med uregelmæssige, koncentriske tilvækstlinier. Ret variabel form. Velbevaret højreskal fra Børglum.

Stratigrafisk udbredelse: England: Glos Oolite Series fra Trigonia clavellata zonen til de nederste zoner i Kimeridge clay. Polen: øvre Oxford, Pommern. 
Oxytoma expansa (Phillips). - Tvl. 7, fig. 73.

Avicula expansa Phillips; 1829, p. 129, pl. 3, fig. 35.

Oxytoma expansa Phillips; Arkell, V. 1933, p. 190, pl. 24, fig. 1-5.

Karakterer: Hængselranden ca. 4/5 af skallens længde, bageste øre med ca. 15-20 radialribber og dyb sinus. Skulpturen på den flade højreskal som på venstreskallen, men udviklingen af primære, sekundære og tertiære radialribber meget mere uregelmæssig end på venstreskallen. Ca. $15 \mathrm{~mm}$ fra umbo 16 til 20 primære radialribber.

Stratigrafisk udbredelse: ARKELL: øvre Cornbrash-Corallian; England.

Oxytoma inaequivalvis (SOWERBY).

Avicula inaequivalvis Sowerby; 1819, III, p. 78, pl. 244, fig. 2.

Avicula (Oxytoma) inaquivalvis SOWERby; 1898, SkeAt \& MAdSEn, p. 78.

Oxytoma inaequivalvis (SOWERBY); ArKelL, V, 1933, p. 194-195, pl. 24, fig. 9. Oxytoma inaequivalvis (Sowerby); Troedsson, 1951, p. 200, pl. 10, fig. 11-14. Karakterer: Skulptur bestående af $14-15$ primære radialribber med fine radialstriber eller -ribber i mellemrummene. Ingen virkelige sekundærribber som hos O. expansa. Det er vanskeligt at afgøre, hvor konstant dette karaktertræk er i materialet fra Gassum p.gr.a. dets fragmentariske tilstand.

Stratigrafisk udbredelse: England: Hele Lias, fra Psiloceras planorbis zonen til Inferior Oolite. Nordvesttyskland: Lias, fra »Angulatenschichten « (=Schlotheimia angulata zonen) til »Amaltheenschichten« (= Amaltheus margaritatus zonen). Bornholm: Lias, Hasle sandstenen (Coroniceras bucklandi zonen?).

\section{Oxytoma sinemuriensis (D'ORBIGNY).}

Avicula sinemuriensis D'OrbIGNY; 1850, 1, 7e ét. p. 219, No. 125.

Oxytoma sinemuriensis D'Orb. Troedsson, 1951, p. 195, pl. 9, fig. 1-11; pl. 10, fig. 1-10.

Karakterer: Minder en del om $O$. inequivalvis, men er mindre skæv og har et større antal grove (primære) radialribber end denne art. Unge former: 14-15 primærribber og en sekundærribbe i de fleste mellemrum. Aldre former: 15-16 primærribber og indtil 3 eller flere sekundærribber i mellemrummene.

Stratigrafisk udbredelse: Troedsson: Döshult stadiet, Skåne (Sinemurien = Lias alphas).

Palaeoneilo galatea (D'ORBIGNy). - Tvl. 7, fig. 76-77.

Leda Galatea D’Orbigny; 1850, 8e ét no. 152.

Leda Galatea D'OrbignY; SkeAt \& MAdSEn, 1898, p. 83.

$9^{*}$ 
Palaeoneilo galatea (D’Orbigny); TroedsSon, 1951, p. 149, pl. 16, fig. 1, 2, 6, 9-11.

Karakterer: Umbo findes $\mathrm{i}$ en afstand af ca. 1/3 af skallængden fra forenden. Hvirvelpartiet relativt stærkt hvælvet. Fure fra umbo langs dorsalranden til bagenden. Længde: højde ca. 1.5-2. Stærk variabel form. Velbevaret venstreskal fra ca. 545 m i Rødby no. 2 med fine, koncentriske tilvækstlinier, der krydses af skæve, koncentriske, flade ribber.

Stratigrafisk udbredelse: SKEAT \& MADSEN: Nordvesttyskland og England: Lias fra Schlotheimia angulata zonen til Coeloceras annulatus zonen (Lias alphaepsilon). Danmark: Blok Nr. 4, Hirtshals, Skeat \& MAdSEN: Uptonia jamesoni zonen (Lias gamma). Troedsson: Skåne: Grammatodon cypriniformis zonen (Lias gamma, nedre Pliensbachien).

Protocardia morinica DE LORIOL. - Tvl. 8, fig. 83.

Protocardia morinica De Loriol; de Loriol \& Pellat, 1866, p. 59, pl. 6, fig. 3-5. Protocardia morinica De LoRIol; SKeAt \& MAdSEN, 1898, p. 132, pl. 3, fig. 5. Karakterer: I modsætning til $P$. striatula har denne art efter SKEAT omtrent samme højde og længde, d.v.s. at skallen nærmest er cirkelrund. De to skalhalvdele er stærkt konvekse, og umbo rager mere frem end hos $P$. striatula. Materialet fra boringerne er ret velbevaret og svarer godt til beskrivelser og afbildninger i litteraturen.

Stratigrafisk udbredelse: SKEAT \& MADSEN: Discina latissima zonen (øvre Kimeridgien) og Perna Bouchardi zonen (nedre Portlandien); Boulogne s.-m., Frankrig. Øvre Kimeridgian (Kimeridge clay) og nedre Portlandian (Portland sand); England. Samme forfattere: forekommer i 13 af 24 blokke, fortrinsvis fra Hirtshalsområdet, som er henført til Kimeridge-Portland.

\section{Protocardia cf. philippiana (DUNKER).}

Cardium Philippianum Dunker; 1847, p. 116, pl. 17, fig. 6. Protocardia philippiana (DUNKER); TrOEDSSON, 1951, p. 178.

Karakterer: Skallen omtrent rund, lidt trekantet; skævt afskåret bagende. Svage, koncentriske striber på hele skaloverfladen. Bag ved kølen, der fra umbo strækker sig ned mod skalranden, findes fine radialstriber. Umbo, der findes omtrent i skallens midterlinie, rager temmelig meget frem. Eksemplaret fra Rødby no. 1 er nærmest en stenkerne, som dog svarer godt til ovennævnte beskrivelse.

Stratigrafisk udbredelse: Troedsson: Psiloceras planorbis zonen, Halberstadt $($ Hettangien $=$ Lias alpha 1$)$; Pullastra bænken, Helsingborg $($ Hettangien $=$ Lias alpha $1-$ alpha $_{2}$ ). 
Pteria contorta (PoRTLOCK). - Tvl. 7, fig. 78.

Avicula contorta PoRTLOcK; 1843, p. 126, pl. 25A, fig. 16.

Avicula contorta PoRTL.; SCHMIDT, 1928, p. 143, fig. 290.

Pteria contorta (PoRTLOCK); ARKell, 1933, pl. 29, fig. 16.

Karakterer: Venstreskal stærkt krummet med uregelmæssige, noget bølgende, båndformede radialstriber. Bageste skaløre halvt så lang som bageste skaldel og med sinus. Højreskallen mindre end venstreskallen. Materialet fra Vinding svarer til beskrivelser og afbildninger i litteraturen, såvidt man kan skønne. Skallerne er fragmentariske. I Gassummaterialet har arten ikke kunnet identificeres.

Stratigrafisk udbredelse: SorgenfreI (1958): Rhaet: England, Irland, Nordtyskland, Sydtyskland, Alpeområdet.

\section{Taeniodon Ewaldi Bornemann.}

Taeniodon Ewaldi Bornemann; SCHMidT, 1928, p. 201, fig. 484.

'Schizodus' Ewaldi (Bornemann) Arkell, 1933, pl. 29, fig. 10.

Karakterer: Elliptisk omrids. Bagrand lige afskåret. Køl fra umbo til hjørnet mellem bagrand og ventralrand. Eksemplarerne fra Gassum er i besiddelse af disse karakterer. Hængsel ikke observeret.

Stratigrafisk udbredelse: SCHMIDT: Rhaet, Tyskland.

\section{Trigonia hudlestoni LyCET. - Tvl. 7, fig. 75.}

Trigonia hudlestoni LyCET; 1877, p. 194, pl. 34, fig. 5-6, pl. 39, fig. 1a, 2.

Trigonia perlata AgAssiz; Arkell, I. 1929, p. 67, pl. 4, fig. 1-7, pl. 5, fig. 1-2. Trigonia hudlestoni LyCET; ARKELL, II, 1930, p. 73-74.

Karakterer: Denne form viser stor lighed med $T$. clavellata. Da begge arter endvidere har meget varierende skaller er afgrænsningen af arterne meget vanskelig. Unge skaller af $T$. hudlestoni er i besiddelse af en tydelig konveksitet på area, hvor den øverste carina møder skalranden. (Dette skulpturelement findes ikke hos $T$. clavellata.). Vinklen hvorunder knuderækkerne løber ind i den nederste carina er normalt mindre end ca. $70^{\circ}$ (hos $T$. clavellata er den $70-80^{\circ}$ ). Eksemplarerne fra Gassum og Haldager svarer bedst til beskrivelse og afbildninger af $T$. hudlestoni.

Stratigrafisk udbredelse: ARKELL: Berkshire Oolite Series: Trigonia hudlestoni beds (inden for Perisphinctes martelli zonen) England.

\section{AMMONOIDEA}

Amaltheus margaritatus DE MONTFORT. - Tvl. 9, fig. 90, 94, 95.

Amaltheus margaritatus DE MONTFORT; 1808, p. 91, fig. p. 90.

Ammonites amaltheus QuenstedT; 1858, p. 166, pl. 20, fig. 1-5. 
Amaltheus margaritatus (MONTFORT); Arkell, 1933, pl. 31, fig. 2.

Karakterer: Ret fladtrykt, skiveformet skal med køl, hvorpå der er udviklet knuder, der danner snorornament. Bølgeformede tværribber og fin spiralstribning. Umbilicus mellem $1 / 3$ og $1 / 4$ af skaldiameteren. På en del eksemplarer fra Gassum kraftige pigge ved umbilicus, andre skaller helt glatte.

Stratigrafisk udbredelse: Frankrig: Nederste Domérien (øverste Charmouthien). England: Nedre del af Middle Lias (fra "The three Tiers" til "Margaritatus Bed"). Nordvesttyskland: Amaltheentone (Lias delta) nedre del. Amaltheus margaritatus zonen anses for at være et snævert interval, velegnet til stratigrafisk korrelation.

Beaniceras ef. centaurus (D'ORBIGNY). - Tvl. 9, fig. 91-92.

Ammonites Centaurus D'Orbigny; 1850, I, p. 224.

Ammonites centaurus D'OrbignY; Quenstedt, 1858, p. 135, pl. 16, fig. 16.

Karakterer: Lille skal med bredt, omvendt trapezoidisk kammertværsnit, enkle lige ribber. Evolut skal. Hverken lobelinier eller skaltværsnit har kunnet iagttages på skallen fra Rødby no. 1. Bestemmelsen derfor usikker.

Stratigrafisk udbredelse: Pliensbachien. Frankrig (Tragophyllum ibex zonen, Lias gamma $=$ Pliensbachien), Nordvesttyskland (HoffmanN, 1963) og England (ARKELL, 1956).

Lyticoceras noricum (SCHLOTHEIM). - Tvl. 10, fig. 102-103.

Ammonites noricus von Schlotheim, 1820, p. 77.

Hoplites noricus Roemer sp.; von Koenen, 1902, p. 174, pl. 31, fig. 3-7.

Karakterer: Lyticoceras med forholdsvis lige og ret tætliggende ribber; ca. halvdelen af ribberne deler sig. Tendens til knudedannelse på ribberne ved umbilicus og randen til ventralsiden. Stærkt opdelt lobelinie.

Stratigrafisk udbredelse: Nedre Hauterivien i Nordvesttyskland. L. noricum zonen synes at være af ringe vertikal udstrækning og betragtes derfor som et velegnet korrelationsinterval.

$\mathrm{D}_{1}-\mathrm{D}_{2}$ horisonterne ved Speeton og i Claxby ironstone (begge nedre Hauterivien) England (Spath, 1924).

Parapallasiceras ef. praecox (SCHNEID). - Tv1. 10, fig. 101.

Parapallasiceras praecox (SCHNeID) Treatise on Invertebr. Paleont. Pt. L. p. L329, fig. 431,2.

Karakterer: Lille, perlemorsskinnende skal med biplicate, regelmæssige ribber fra Haldager svarer fuldkommen til beskrivelse og afbildning i "Treatise". Lobelinierne har dog ikke kunnet iagttages. Der er utvivlsomt tale om $P$. praecox eller en meget nærstående art. 
Stratigrafisk udbredelse: Neuburger Schichten i Sydtyskland (Beriasella ciliata og Anavirgatites palmatus zonerne). Svarer muligvis til Pectinatites pectinatus zonen i England (ArKelL, 1956).

Paravirgatites cf. paravirgatus (BUCKMAN). - Tvl. 10, fig. 98-100.

Paravirgatites paravirgatus (Buck.) Treatise on Invertebr. Paleont. Pt. L p. L332, fig. 435,3 .

Karakterer: Den fragmentariske skal fra Gassum (1139-1145 m) svarer i sine karaktertræk helt til afbildning og beskrivelse i "Treatise", hvortil der derfor henvises. Lobelinierne kan iagttages, og skallen har det typiske uregelmæssige tværsnit samt de kraftige ribber, der fremhæves som slægtskendetegn.

Stratigrafisk udbredelse: Basis af øvre Kimeridge, Pectinatites pectinatus zonen, England.

\section{Pleuroceras spinatum (BRUGUIÈRE).}

Ammonites spinatus Bruguière 1789 (in Treatise on Invert. Paleontol. L, p. L251, fig. 282,2).

Paltopleuroceras spinatum (Bruguière); Arkell, 1933, pl. 31, fig. 1.

Karakterer: Kvadratisk vindingstværsnit. Kraftige ribber med kraftige knuder ved ventro-lateralkanten. Fremstående køl med knuder på ventralsiden. Stærkt opdelt lobelinie. Evolut. Brudstykket fra Gassum passer godt til denne beskrivelse, men lobelinier kan ikke iagttages.

Stratigrafisk udbredelse: Frankrig: Domérien (øverste Charmouthien), England: Thorncombe sands (øverste del af Middle Lias). Nordvesttyskland: Amaltheentone, Lias delta $=$ Domérien. Pleuroceras spinatum zonen findes øverst i alle disse formationer; bruges som korrelationsinterval.

\section{Promicroceras planicosta (SOWERBY).}

Ammonites planicosta Sowerby; 1812, I, p. 167, pl. 73.

Promicroceras planicosta (Sow.) Treatise on Invert. Paleont. L, p. L247, fig. 272,2 .

Karakterer: Ribberne uden pigge, lige og kraftige. Omtrent rundt vindingstværsnit. Meget kompleks lobelinie. Evolut skal. Skallerne fra Gassum og Vinding passer godt til diagnosen og beskrivelser i litteraturen.

Stratigrafisk udbredelse: Asteroceras obtusum zonen = øvre Sinemurien, Nordvesttyskland (= Lias beta) (HofFMAnN, 1949, 1963), Pariserbassinet (GignouX, 1950), England, bl. a. Yorkshirebassinet (Arkell, 1933). 
Psiloceras planorbis (SOWERBY). - Tvl. 9, fig. 89.

Ammonites Planorbis Sowerby; 1825, V, p. 69, pl. 448.

Psiloceras planorbis (Sowerby); ARKell, 1933, pl. 30, fig. 7 \& 1956, pl. 31, fig. 7.

Psiloceras planorbis (Sow.) Treatise on Invert. Paleont. L, p. L232, fig. 258.10. Karakterer: Smal, skiveformet, evolut skal, der er perlemorsskinnende. Simpel sutur. Meget tynd og skrøbelig skalvæg. Denne typiske art har let kunnet identificeres i materialet fra Rødby no. 1.

Stratigrafisk udbredelse: Hettangien, Psiloceras planorbis zonen, Frankrig (Gignoux), Tyskland (Lias alpha) (HoFfmann, 1949, 1963), England (Arkell, 1933, 1956).

Schlotheimia angulata (SCHLOTHEIM). - Tvl. 9, fig. 96-97.

Ammonites angulatus Schlotheim; 1820, p. 70.

Scamnoceras angulatum (SCHLOTHeIM); ARKell, 1933, pl. 30, fig. 6.

Schlotheimia angulata (SCHLOTHEIM); Arkell, 1956, pl. 31, fig. 5-6.

Karakterer: Relativt flad skal (høje kamre) med svagt buede, ret kraftige ribber, der mødes på ventralsiden. Ret enkel lobelinie. Adskillige eksemplarer fra Gassum.

Stratigrafisk udbredelse: Hettangien, Schlotheimia angulata zonen: Frankrig (Gignoux, 1950), Nordtyskland (= Lias alpha, nedre del, Hoffmann, 1949, 1963), England (Blue Lias limestones Arkell, 1933, 1956).

\section{BELEMNITES}

Belemnites (Aulacoteuthis?) magnificus (D’ORBIGNY). - Tvl. 10, fig. 104-110.

Belemnites magnificus D'Orbigny, 1845, p. 425, pl. 31, fig. 7, 1-5.

Belemnites magnificus D'OrbignY; 1892, PAvlow, p. 224, pl. 5, fig. 1, 2.

Karakterer: Rostrum meget slank. Subcylindrisk til ovalt, affladet tværsnit. Tydelig fure ved apex, der udvider sig til et lancetformet, fladt parti på midten af rostrum. Phragmoconen kort. Eksemplarerne fra Haldager svarer godt til beskrivelser og afbildninger hos D'ORBIGNY og PAvLow. Phragmoconen på det bedst bevarede eksemplar ca. 1/5 af rostrums længde. Dette eksemplar har en meget svag lateralfure på hver side af rostrum. Apicallinien ligger excentrisk, nærmet ventralsiden.

Stratigrafisk udbredelse: England: øverste Kimeridge. Sovjetunionen: øverste Kimeridge og nedre Portland (nedre Volgien, Virgatites virgatus zonen). 


\section{LITERATURE}

\section{Foraminifera}

Bartenstein, Helmut \& Erich Brand, 1937. Mikro-paläontologische Untersuchungen zur Stratigraphie des nordwest-deutschen Lias und Doggers. Abh. Senckenb. Naturf. Ges., Abh. 439, Frankfurt a. M.

Bartenstein, Helmut \& Erich Brand, 1951. Mikropaläontologische Untersuchungen zur Stratigraphie des nordwestdeutschen Valendis. Abh. Senckenb. Naturf. Ges. 485, p. 239, Frankfurt a. M.

Batjes, D. A. J., 1958. Foraminifera of the Oligocene of Belgium. Mém. Inst. Royal Sci. Nat. Belgique, no. 143, Bruxelles.

Berggren, W. A., 1960. Some planktonic Foraminifera from the lower Eocene (Ypresian) of Denmark and northwestern Germany. Stockholm Contr. Geol., vol. 5, no. 3, p. 41, Stockholm.

Bettenstaedt, Franz, 1952. Stratigraphisch wichtige Foraminiferen-Arten aus dem Barrême vorwiegend Nordwest-Deutschlands. Senckenbergiana, Band 33, 4/6, p. 263, Frankfurt am Main.

BRAND, ERICH, 1949. Neue Ergebnisse zur mikropaläontologischen Gliederung des nordwestdeutschen Dogger und Valendis. Erdöl und Tektonik in Nordwestdeutschland, p. 335, Hannover.

Brotzen, Fritz, 1936. Foraminiferen aus dem schwedischen, untersten Senon von Eriksdal in Schonen. Sveriges Geol. Undersökning, ser. C. no. 396, Stockholm.

Brotzen, Fritz, 1940. Flintrännans och Trindelrännans Geologi (Öresund). Sveriges Geol. Undersökning, ser. C. n: o 435, Stockholm.

Brotzen, Fritz, 1942. Die Foraminiferengattung Gavelinella nov. gen. und die Systematik der Rotaliiformes. Sveriges Geol. Undersökning, ser. C. n: o 451, Stockholm.

Brotzen, Fritz, 1945. De geologiska resultaten från borrningarna vid Höllviken. Del I: Kritan. Sveriges Geol. Undersökning, ser. C. n:o 465, Stockholm.

Brotzen, F., 1948. The Swedish Paleocene and its Foraminiferal Fauna. Sveriges Geol. Undersökning, ser. C. n: o 493, Stockholm.

Cushman, J. A., 1922. The Foraminifera of the Byram Calcareous Marl at Byram, Mississippi. U. S. Geol. Survey, Prof. Paper No. 129-E, Washington D.C.

Cushman, J., 1927. Some Notes on the Genus Ceratobulimina. Contr. Cushman Lab. Foram. Res., vol. 3, pt. 4, p. 171.

Cushman, J., 1939. A Monograph of the Foraminiferal Family Nonionidae. U. S. Geol. Surv., Prof. Paper No. 191, Washington.

Dam, A. Ten, 1944. Die stratigraphische Gliederung des niederländischen Paläozäns und Eozäns nach Foraminiferen (mit Ausnahme von Süd-Limburg). Mededeel. geol. Stichting, serie C-V-no. 3, Maastricht.

Dam, A. Ten, 1948. Les espèces du genre Epistomina Terquem 1883. Inst. Franc. Pétrole, Rev., vol. 3, no. 6, Paris, p. 161.

Dam, A. Ten, \& Th. ReInhold, 1941. Asterigerinen als Index-Foraminiferen für das nordwest-europäische Tertiär. Geol. Mijnbouw, n. ser., bd. III, no. 7, p. 220, Haag. 
Dam, A. Ten \& Th. ReInhold, 1942. Die stratigraphische Gliederung des niederländischen Oligo-Miozäns nach Foraminiferen (mit Ausnahme von S. Limburg). Mededeel. geol. Stichting, serie C-V-no. 2, Maastricht.

Dinesen, Arne, 1959, see Larsen \& Dinesen, 1959.

Ellis, B. F. \& A. R. Messina, 1940 f.f. Catalogue of Foraminifera. Am. Mus. Nat. Hist. Spec. Pub. New York.

Franke, A., 1927. Die Foraminiferen und Ostracoden des Paleocäns von Rugaard in Jütland und Sundkrogen bei Kopenhagen. D.G.U., II. rk. nr. 46, København.

Franke, A., 1928. Die Foraminiferen der Oberen Kreide Nord- und Mitteldeutschlands. Abh. Preuss. Geol. Landesanst., N. F., H. 111, Berlin.

Franke, A., 1936. Die Foraminiferen des deutschen Lias. Abh. preuss. geol. Landesanst. N. F. H. 169 , Berlin.

GüMBEL, C. W., 1868 (1870). Beiträge zur Foraminiferenfauna der nordalpinen, älteren Eocängebilde oder der Kressenberger Nummulitenschichten. Abh. Mathem. C1. Kön. Bay. Akad. Wissensch., vol. 10, 2. Abth., p. 581, München.

Hiltermann, H. \& W. Koch, 1950. Taxonomie und Vertikalverbreitung von BolivinoidesArten im Senon Nordwestdeutschlands. Geol. Jahrb., Bd. 64, p. 595, Hannover/Celle.

Hiltermann, H. \& W. Koch, 1956. Mikropaläontologische Feinhorizontierung von Santon-Profilen durch das Erzlager Lengede-Broistedt. Paläont. Zeitschr., vol. 30, Sonderheft, p. 33, Stuttgart.

Hiltermann, H. \& W. Koch, 1957. Revision der Neoflabellinen (Foram.) I. Teil: Neoflabellina rugosa (D'ORв.) und ihre Unterarten. Geol. Jahrb., vol. 74, p. 269, Hannover.

HOFKer, J., 1948. On Asterigerina gürichi (FRANKe) and remarks on polymorphism and the stratigraphic use of foraminifera. Jour. Pal. vol. 22, p. 509, Menasha (Wisconsin, U.S.A.).

Hofker, J., 1951. The Foraminifera of the Siboga Expedition, part III, Ordo Dentata. Siboga-Expeditie, Monographie IV a, Leiden.

Hofker, J., 1952. The Jurassic Genus Reinholdella Brotzen (1948) (Foram.). Paläont. Zeitschr., vol. 26, nr. 1-2, p. 15, Stuttgart.

Hofker, J., 1956. Foraminifera from the Cretaceous of Southern Limburg, Netherlands, XXI. - Natuurhist. Maandbl., 45e Jaarg., no. 9-10, p. 99, Maastricht.

Hofker, J., 1957. Foraminiferen der Oberkreide von Nordwestdeutschland und Holland. Beihefte Geol. Jahrb., Heft 27, Hannover.

HOFKer, J., 1958. The evolution of Mississippina binkhorsti (Reuss). Natuurhist. Maandbl., vol. 47, nr. 7-8, p. 101, Maastricht.

INDANS, JULIJA, 1958. Mikrofaunistische Korrelationen im marinen Tertiär der Niederrheinischen Bucht. Fortschr. Geol. Rheinland u. Westfalen, Bd. 1, p. 223, Krefeld.

KaAsschieter, J. P. H., 1961. Foraminifera of the Eocene of Belgium. Inst. Royal Sci. Nat. Belgique, Mém. no. 147, Bruxelles.

Lange, Wolfgang, 1956. Grundproben aus Skagerak und Kattegat, mikrofaunistisch und sedimentpetrographisch untersucht. Meyniana, Band 5, p. 51, Kiel.

Larsen, Gunnar \& Arne Dinesen, 1959. Vejle Fjord Formationen ved Brejning. Sedimenterne og foraminiferfaunaen (oligocæn-miocæn). D.G.U. II. rk. nr. 82, København.

Marks, Peter, Jr., 1951. A Revision of the Smaller Foraminifera from the Miocene of the Vienna Basin. Contr. Cushman Found. Foram. Res., vol. 2, no. 2, no. 29, p. 33, Washington.

Marsson, Th., 1878. Die Foraminiferen der weissen Schreibkreide der Insel Rügen. Mitt. naturwiss. Vereins Neuvorpommern Rügen, 10 Jahrg. p. 115, Greifswald.

Nørvang, A., 1957. The Foraminifera of the Lias Series in Jutland, Denmark. D.G.F., Bd. 13, p. 275, København. 
D'Orbigny, A., 1846. Foraminifères fossiles du bassin tertiaire de Vienne (Autriche). Gide et Comp., p. 151, Paris.

ReIss, Z., 1954. Upper Cretaceous and Lower Tertiary Bolivinoides from Israel. Contr. Cushman Found. Foram. Res., 5, pt. 4, Washington.

Reuss, Aug. E., 1862. Die Foraminiferen des Kreidetuffs von Maastricht. Sitzungsberichte Kaiserl. Akad. Wissensch. Matem. Naturw. Classe, Bd. 44, 1. Abt., Wien.

Reuss, A. E., 1863. Die Foraminiferen des norddeutschen Hils und Gault. Sitzungsberichte Kaiserl. Akad. Wissensch. Mathem. Naturw. Classe, Bd. 46, 1. Abt., Wien.

Simon, W. \& H. Bartenstein (ed.) m. fl. 1562. Leitfossilien der Mikropaläontologie. BerlinNikolassee.

Staesche, K. \& H. Hiltermann, 1940. Mikrofaunen aus dem Tertiär Nordwestdeutschlands. Abh. Reichsstelle für Bodenforschung, N. F., H. 201, Berlin.

Sztejn, JANINA, 1957. Stratygrafia Mikropaleontologiczna dolnej kredy w polce Srodkowej. (Micropalaeontological Stratigraphy of the Lower Cretaceous in Central Poland). Instytut Geologiczny Praće, Tom XXII, Warszawa.

Troelsen, J. C., 1937. Om den stratigrafiske Inddeling af Skrivekridtet i Danmark. D.G.F. Bd. 9, p. 1. København.

Troelsen, J. C., 1954. Studies on Ceratobuliminidae (Foraminifera). D.G.F. Bd. 12. p. 448. København.

Voorthuysen, J. H. VAn, 1950. The quantitative distribution of the Plio-Pleistocene Foraminifera of a boring at the Hague (Netherlands). Mededel. geol. Sticht., n. s. no. 4, p. 31, Haarlem.

\section{Graptolithina, Mollusca}

Arkell, W. J., 1926. Studies in the Corallian Lamellibranch Fauna of Oxford, Berks and Wilts. Geol. Mag. vol. 63, p. 193 og 534. London.

Arkell, W. J., 1929-1937. A Monograph of British Corallian Lamellibranchia. Part I-X. Palæontographical Society. London.

ArKell, W. J., 1933. The Jurassic System in Great Britain. Oxford.

Arkell, W. J., 1956. Jurassic Geology of the World. Edinburgh.

Blake, J. F. \& W. H. Hudleston, 1877. The Corallian Rocks of England. Quart. Journ. Geol. Soc. vol. 33, p. 260. London.

Bornemann, I. A., 1856. Über organische Reste der Lettenkohle Thüringens.

Brand, E. \& K. Hoffmann, 1963. Stratigraphie und Fazies des nordwestdeutschen Jura und Bildungsbedingungen seiner Erdöllagerstätten. Erdöl u. Kohle. 1963, Juni, p. 437. Hamburg.

Bubnoff, S. von, 1952. Fennosarmatia. Berlin.

Dittmar, A. von, 1864. Uber die zone der Avicula contorta Portl. München.

Dunker, W., 1846-1851. Ueber die in dem Lias bei Halberstadt vorkommenden Versteinerungen. Paleontographica 1. Cassel.

Elles \& WoOD, 1901-18. Monograph of British Graptolites. London.

Gignoux, M., 1950. Géologie Stratigraphique. Paris.

Goldfuss, A., 1826-1844. Petrefacta Germaniae. Düsseldorf. (Bd. 2)

Grönwall, K. A. \& V. Milthers, 1916. Kortbladet Bornholm. D.G.U. I. rk. nr. 13. København.

Hoffmann, K., 1949. Zur Paläogeographie des nordwestdeutschen Lias und Doggers. Erdöl u. Tektonik in Nordwestdeutschland. Celle.

Hoffmann, K., 1963. See Brand.

Hudleston, W. H., 1876-78. The Yorkshire Oolites, Part II. The Middle Oolites. Proc. Geol. Assoc. vol. 4, 1876, and vol. 5, 1878. London. 
Koenen, A., von, 1902. Die Ammonitiden des Norddeutschen Neokom. Abh. Preuss. Geol. Landesanst. NF. H. 24. Berlin.

LAMARCK, 1802. Système des animaux sans vertèbres. Paris.

LAMPlugh, G. W., 1896. On the Speeton Series in Yorkshire and Lincolnshire. Q.J.G.S. vol. 52. London.

Lamplugh, G. W., 1924. A Review of the Speeton Clays. Proc. Yorks. Geol. Soc., N.S., vol. 20, p. 1. Manchester.

Loriol, P. \& E. Pellat, 1866. Monographie paléontologique et géologique de l'étage portlandien des environs de Boulogne-sur-mer. Mém. soc. phys. vol. XIX, Genève.

Lund Gren, B., 1879. Bidrag til Kännedomen om Juraformationen på Bornholm. Festskr. t. Univ. i Köpenhamn v. dess jubileum 1879 fr. Lunds Univ. Lund.

Lycett, J. 1872-83. A Monograph of the British Fossil Trigoniæ. Palæontographical Society. London.

Malling, C. og K. A. Grönwall, 1909. En Fauna i Bornholms Lias. Medd. D.G.F. Bd. 3, p. 271, København.

Montfort, Denys De., 1808-10 Conchyliologie systématique et classification méthodiques des coquilles vol: $1-2$. Paris.

Murchison, R. I., Verneuil, E. De. \& Keyserling, A., von, 1845. The Geology of Russia in Europe and the Ural Mountains. (2 vol.). London.

Oppel, A., 1856-58. Die Juraformation Englands, Frankreichs und des Südwestlichen Deutschlands. Stuttgart.

Oppel, A., 1862-1863. Ueber jurassische Cephalopoden. Pal. Mitt. Mus. K. Bay. Staates vol. III.

D’Orbigny, A., 1844. Paléontologie Française. Terrains jurassiques. Paris.

D'Orbigny, A., 1850. Prodrome de paléontologie stratigraphique universelle des animaux mollusques et rayonnés. Paris.

Pavlow, A. \& G. W. Lamplugh, 1892. Argiles de Speeton et leurs équivalents. Bull. Soc. Imp. des Nat. de Moscou. N.S.T.V. p. 181, 455-570. Moskva.

Pavlow, A. P., 1907. Enchainements des Aucelles et Aucellines du Crétacé Russe, Nouv. hém. Soc. Imp. Nat. Moscou, vol. XVII livr. 1.

Phillips, J., 1829. Illustrations of the Geology of Yorkshire.

Portlock, J. E., 1843. Report on the Geology of the County of Londonderry, and parts of Tyrone and Fermanagh, Dublin.

Quenstedt, F. A., 1845-1849. Petrefactenkunde Deutschlands. Die Cephalopoden. M. Atlas. Tübingen.

Quenstedt, F. A., 1858. Der Jura. Tübingen.

Quenstedt, F. A., 1883-88. Die Ammoniten des Schwäbischen Jura. 3 vol. \& 3 vol. Atlas. Stuttgart.

Schäfle, L., 1929 .Über Lias- und Doggeraustern. Geol. u. Pal. Abh. N.F. 17. Jena.

Schlotheim, 1820-22. Die Petrefactenkunde auf ihrem jetzigen Standpunkte. Gotha.

Schmidt, M., 1905. Über Oberen Jura in Pommern. Abh. Preuss Geol. Landesamt (NF) H. 41. Berlin.

SchmidT, M., 1928. Die Lebewelt unserer Trias. Oehringen.

Skeat, Ethel \& Victor Madsen, 1898. On Jurassic, Neocomian and Gault boulders found in Denmark. D.G.U. II. række nr. 8. København.

Sorgenfrei, Theodor, 1957. Lexique Stratigraphique International. Vol. 1. F. 2 d. Danemark. Paris.

SorgenfreI, Theodor, 1958. The Rhaetic, a stratigraphic study. (Internal report).

Sowerby, J., 1812-1829. The Mineral Conchology of Great Britain. London.

Spath, L. F., 1924. On the Ammonites of the Specton Clay and the subdivision of the Neocomian. Geol. Mag. vol. 61. p. 73. London. 
Swinnerton, H. H., 1936-1955. A Monograph of British Lower Cretaceous Belemnites. Palæontographical Soc. London.

Troedsson, G., 1951. On the Höganäs Series of Sweden (Rhaeto-Lias). Skr. fr. Miner. och Pal.-Geol. Inst. Lund.

Uhlig, V., 1882. Die Jurabildungen in der Umgebung von Brünn. Beitr. z. Pal. u. Geol. Oesterreich-Ungarns u. des Orients. Vol. 1.

\section{Borings}

Buch, Arne, 1960. See Larsen, G. \& Arne Buch.

Christensen, Ole BruUn, 1962. Ostracodtyper fra Keuper-Rhaet lagserien i dybdeboringerne ved Harte og Ullerslev. Medd. Dansk Geol. Foren. Bd. 15, p. 90. København.

Dinesen, Arne, 1960. Dybdeboringer på Sjælland, Lavø nr. 1. Medd. Dansk Geol. Foren. Bd. 14 , p. 280 . København.

Dinesen, Birthe, 1961. Salt Mineralvand fra Danmarks dybere Undergrund. D.G.U. IV. rk. bd. 4. nr. 6. København.

Gregersen, Albert \& Theodor Sorgenfrei, 1951. Efterforskningsarbejdet i Danmarks dybere undergrund. Medd. Dansk Geol. Foren. Bd. 12, p. 141. København.

Holmsen, Per, 1958. Alkalisyenitter av Oslo-feltets eruptivstamme i Danmarks dypere undergrunn. Medd. Dansk Geol. Foren. Bd. 14, p. 61. København.

KALIBORINGERNE ved Suldrup 1959-1961. Rapport, udarbejdet af Egnsudviklingsrådets Boreudvalg i samarbejde med Saltudvalget og Danmarks geologiske Undersøgelse. København 1962.

Kehrer, Wilhelm \& Jakob Andres, 1953. Ergebnisse neuerer geophysikalischer Untersuchungen im nördlichen Schleswig-Holstein und Versuche ihrer geologischen Deutung. Neues Jb. Geol. u. Paläontol., Abh. 97, p. 79, Stuttgart.

Larsen, Gunnar, \& Arne Buch, 1960. Dybdeboringer på Sjælland, Slagelse nr. 1. Medd. Dansk Geol. Foren. Bd. 14, p. 281. København.

Larsen, Gunnar, 1964. Rhaetic-Jurassic-Lower Cretaceous Sediments from deep wells in North Jylland, Denmark. Developments in Sedimentology. Vol. 1. Amsterdam.

Noe-Nygaard, Arne, 1951. Det jydske grundfjeld. Medd. Dansk Geol. Foren. Bd. 12, p. 165. København.

Noe-NygaArd, Arne, 1963. The Precambrian of Denmark. The Geologic Systems, Vol. I. p. 1. London.

Nørvang, Aksel, 1946. Marine Lias in Jutland. Medd. Dansk Geol. Foren. Bd. 11, p. 139. København.

Nørvang, Aksel, 1957. The Foraminifera of the Lias Series in Jutland, Denmark. Medd. Dansk Geol. Foren. Bd. 13, p. 275. København.

PAPE, C. H. 1945. Studier over Grundvand. København.

Rasmussen, Leif BAnke, 1958. Nyere tyske undersøgelser i Sydslesvigs undergrund og deres betydning for Danmarks geologi. Medd. Dansk Geol. Foren. Bd. 13, p. 502. København.

SALTFUnDET ved Harte den 13. November 1936. Beretning afgivet af det af Ministeriet for offentlige Arbejder den 24. Januar 1946 nedsatte Udvalg til Revision af Undergrundslovene. København 1948.

Saltudvalget. 1959. Betænkning. A.T.V. Beretning Nr. 35. København.

SORGENFREI, THEODOR, 1951a. Oversigt over prækvartærets topografi, stratigrafi og tektonik i området Fyn-Sydsjælland-Lolland-Falster-Møn. Medd. Dansk Geol. Foren. Bd. 12, p. 166. København.

Sorgenfrei, Theodor, 1951b. See Gregersen. 
Sorgenfrei, Theodor, 1953-1964. Dybgrundens geologi. - Trap. Danmark Bd. 1-8 København.

Sorgenfrei, Theodor, 1957 a. Danemark. Lexique Stratigraphique International. Vol. I, Fasc. 2d. Paris.

Sorgenfrei, Theodor, 1957 b. Perm-systemet i det sydlige Danmark. Medd. Dansk Geol. Foren. Bd. 13, p. 263. København.

Sorgenfrei, Theodor, 1958 a. Molluscan Assemblages from the Marine Middle Miocene of South Jutland and their Environments. Vol. I-II. C. A. Reitzel Publisher. København.

Sorgenfrei, Theodor, 1958 b. Geologiske forholds betydning for vandindvindingen. »Vandbalance«. Teknisk Forlag. København.

Sorgenfrei, Theodor, 1964. Jura und Unterkreide in Dänemark. Z. deutsch geol. Ges. Bd. 114/II, p. 446. Stuttgart.

Stille, Hans, 1930. Das Einsetzen der »saxonischen« Richtung im westdeutschen Jung。 paläozoicum. Abh. Preuss. Geol. Landesanst. N. F. Heft 116. Berlin.

Ødum, Hilmar, 1960. Saltefterforskningen i Danmark. D.G.U. III. række. nr. 34. København. 
PLATES 
Plate 1.

Fig. 1. Reophax multilocularis Haeusler; Flyvbjerg No. 1, 1155-1160 m, Lias, p. 124.

Fig. 2. Reinholdella $c f$. dreheri (BARTENSTEIN); Vedsted No. 1, 1320-1325 m, Dogger, p. 124.

Fig. 3. Reinholdella of. dreheri (BARtenstein); Fjerritslev No. 2, 1347-1350 m, Dogger, p. 124.

Fig. 4. Planularia crepidularis (Roemer); Fjerritslev No. 2, 523-526 m, BarremianHauterivian, p. 122.

Fig. 5. Lenticulina d'orbignyi (Roemer); Vemb No. 1, 1554-1557 m, Dogger, p. 118.

Fig. 6. Lenticulina eichenbergi BARTENSTEIN \& BRAND; Hönning No. 1, 975-980 m, Lower Cretaceous, p. 117.

Fig. 7. Epistomina caracolla (Roemer); Vedsted No. 1, 814-820 m, Hauterivian, p. 113.

Fig. 8. Epistomina spinulifera (Reuss); Fjerritslev No. 1, 349-352 m, Barremian, p. 114.

Fig. 9. Conorotalites intercedens (BettenstaedT); Vemb No. 1, 1425-1428 m, Barremian, p. 111.

Fig. 10. Saracenaria bronnii (Roemer); Horsens No. 1, 1173-1178 m, Aptian, p. 125.

Fig. 11. Gavelinopsis cenomanica (Brotzen); Aabenraa No. 1, 908-911 m, Cenomanian, p. 115.

Fig. 12. Globorotalites michelinianus (D'OrbignY); Aabenraa No. 1, 552-555 m, Santonian, p. 116.

Fig. 13. Stensioeina exsculpta (Reuss); Aabenraa No. 1, 668-671 m, Santonian, p. 126.

Fig. 14. Neoflabellina rugosa (D'OrBIGNY); Horsens No. 1, 624-629 m, Campanian, p. 120.

All figures $50 \mathrm{x}$

Phot. J. A. Troels-Smith 


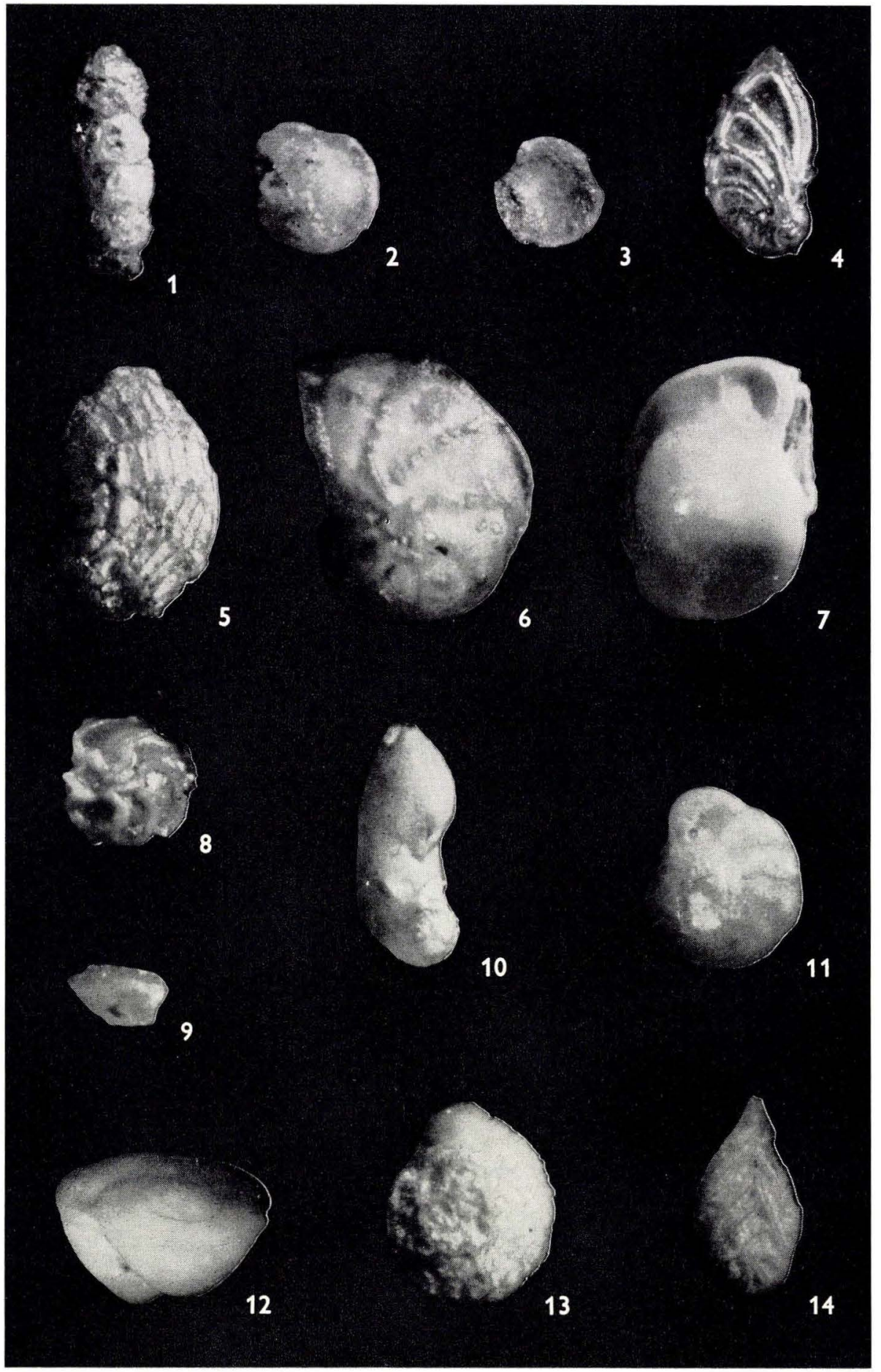


Plate 2.

Fig. 15. Pseudovalvulineria cf. lorneiana (D'Orbigny); Aabenraa No. 1, 543-546 m, Campanian, p. 123.

Fig. 16. Reussella pseudospinulosa Troelsen; Aabenraa No. 1, 530-533 m, Lower Maastrichtian, p. 125.

Fig. 17. Angulogavelinella bettenstaedti Hofker; Aabenraa No. 1, 530-533 m, Lower Maastrichtian, p. 104.

Fig. 18. Bolivina incrassata Reuss; Grindsted No. 1, 425-430 m, Maastrichtian, p. 105.

Fig. 19. Buliminella laevis (BEISSEL); Flyvbjerg No. 1, 342-347 m, Maastrichtian, p. 108.

Fig. 20. Stensioeina pommerana Brotzen; Horsens No. 1, 539-544 m, Maastrichtian, p. 127.

Fig. 21. Bolivina incrassata Reuss; Hönning No. 1, 443-448 m, Maastrichtian, p. 105.

Fig. 22. Bolivinoides draco (MARsson); Rödekro No. 1, 435-440 m, Maastrichtian, p. 106.

Fig. 23. Stensioeina pommerana BRotzen; Rödekro No. 1, 425-428 m, Maastrichtian, p. 127.

Fig. 24. Pseudotextularia elegans (Rzeнак); Glamsbjerg No. 1, 232-236 m. Upper Maastrichtian, p. 123.

All figures $50 \mathrm{x}$

Phot. J. A. Troels-Smith 

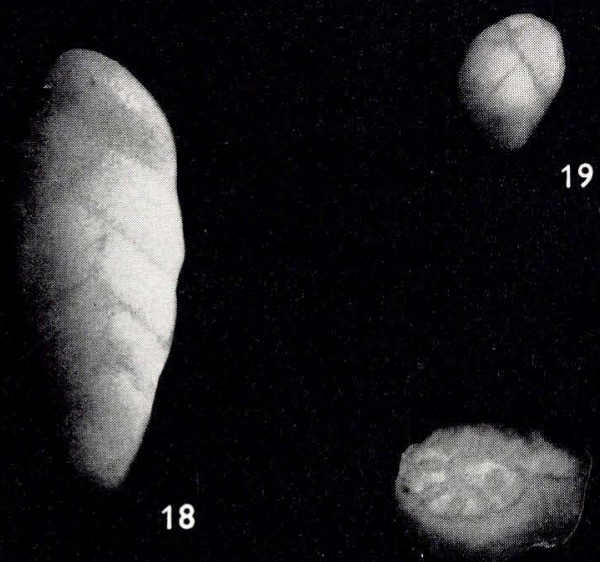

21

20

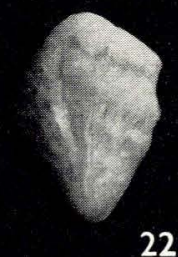

22

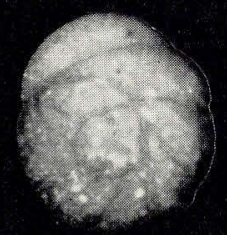

23 
Plate 3.

Fig. 25. »Discorbis « binkhorsti (Reuss); Rödekro No. 1, 390-395 m, Danian, p. 112. Fig. 26. Pyramidina curvisuturata Brotzen; Tönder No.2,477-482 m. Upper Danian, p. 124.

Fig. 27. Gavelinopsis cf. involuta (REUss); Rödekro No. 1, 390-395 m, Danian, p. 115.

Fig. 28. Cibicides voltzianus (D’Orbigny); Slagelse No. 1, 268-273 m, Danian, p. 110. Fig. 29. Osangularia lens Brotzen; Hönning No. 1, 418-423 m, Danian, p. 121.

Fig. 30. Bulimina trigonalis TeN DAM; Slagelse No. 1, 195-200 m, Paleocene, p. 107. Fig. 31. Spiroplectammina spectabilis (Grzybowski); Vinding No. 1, 488-491 m, Paleocene, p. 126.

Fig. 32. Nodosaria torsicostata Ten DAM; Slagelse No. 1, 135-140 m. Fragment, single chamber, Paleocene, p. 121.

Fig. 33. Nodosaria torsicostata TEN DAM; same specimen as fig. 32 photographed in a deeper optic plane, p. 121.

All figures $50 \mathrm{x}$

Phot. J. A. Troels-Smith 


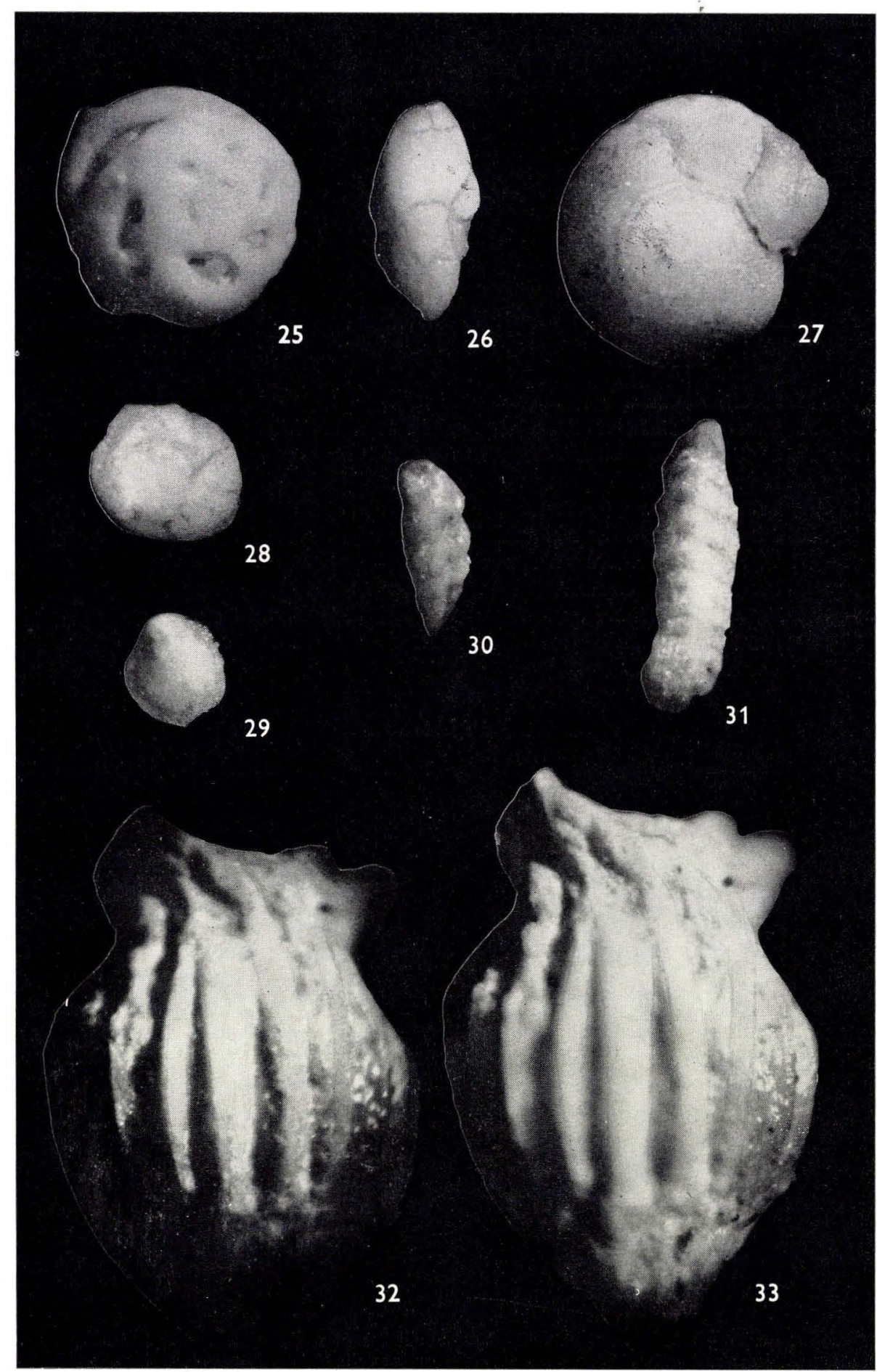




\section{Plate 4.}

Fig. 34. Anomalinoides grosserugosa (GüMBEL); Rödekro No. 1, 375-380 m, Paleocene, p. 104.

Fig. 35. Anomalinoides grosserugosa (GüMBEL); Hönning No. 1, 403-408 m. Lower Eocene, p. 104.

Fig. 36. Eponides candidulus (SchwAGER); Aabenraa No. 1, 207-210 m. Upper Eocene, p. 114.

Fig. 37. Gaudryina hiltermanni MeIsL; Tönder No. 2, 434-436 m, Lower Eocene, p. 114.

Fig. 38. Globigerina yeguaensis Weinzierl \& Applin; Aabenraa No. 1, 362-365 m. Lower Eocene, p. 116.

Fig. 39. Cibicides sulzensis (Herrmann); Aabenraa No. 1, 210-213 m. Upper Eocene, p. 110. Fig. 40. Clavulina parisiensis D'OrBIGNY; Ullerslev No. 1, 27-32 m. Paleocene, p. 111. Fig. 41. Vaginulinopsis decorata (Reuss); Rödekro No. 1, 295-300 m. Upper Eocene, p. 129.

Fig. 42. Ceratobulimina contraria (Reuss); Vinding No. 1, 336-338 m. Oligocene, p. 109. Fig. 43. Asterigerina guerichi (FrANKE); Vinding No. 1, 297-299 m. Upper Oligocene, p. 105. Fig. 44. Spiroplectammina carinata (D'OrbignY); Aabenraa No. 1, 207-210 m. Upper Eocene, p. 126.

All figures $50 \mathrm{x}$

Phot. J. A. Troels-Smith 


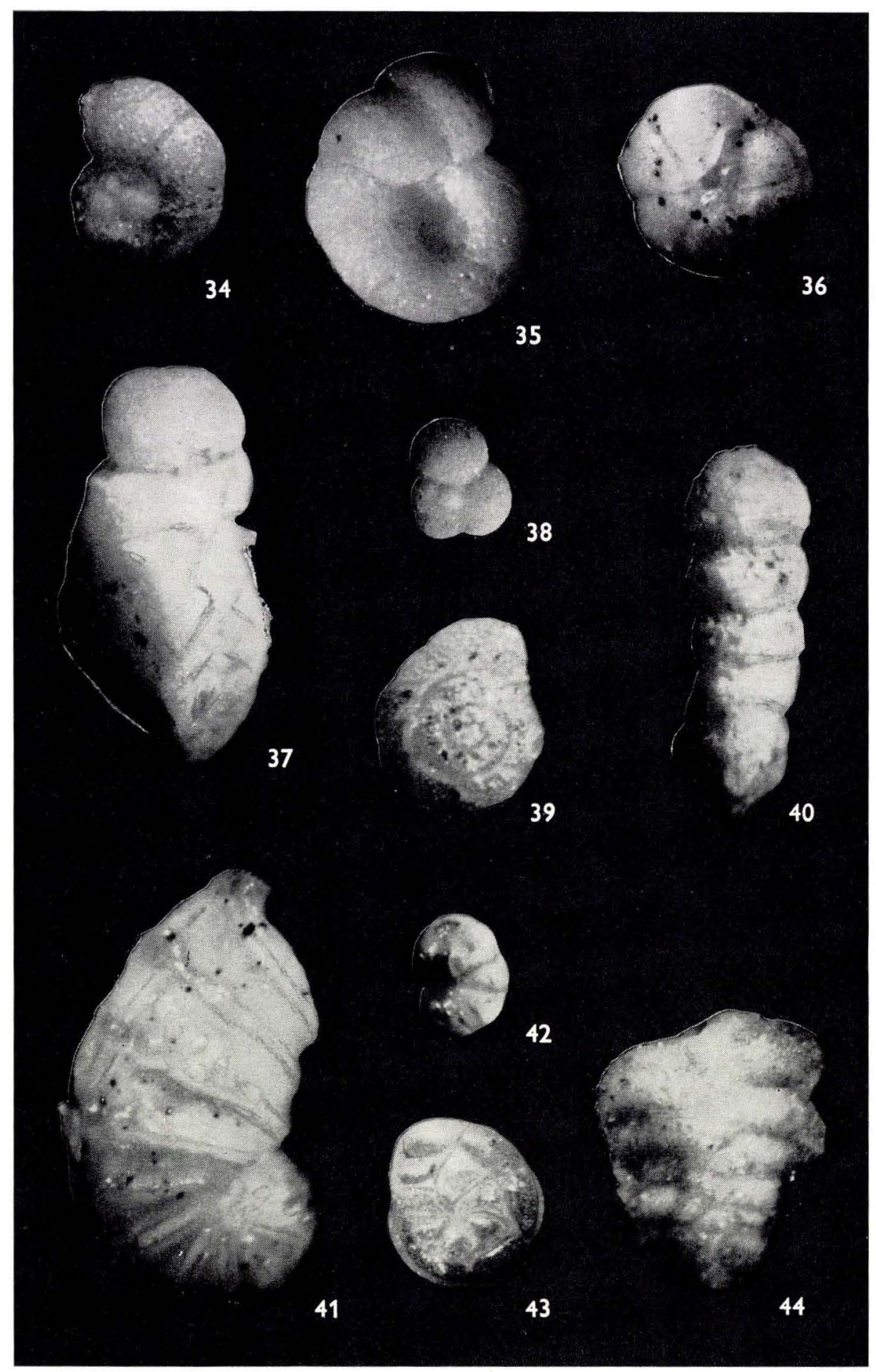


Plate 5.

Fig. 45. Cancris auriculus (Fichtel \& Moll); umbilical side, Arnum No. 1, $46-49$ m, Miocene, p. 108.

Fig. 46. Bulimina elongata D’OrbignY; Tönder No. 2, 148-152 m, Miocene, p. 107.

Fig. 47. Cancris auriculus (Fichtel \& Moll); spiral side, Tönder No. 2, 148-152 m, Miocene, p. 108.

Fig. 48. Asterigerina staeschei Ten Dam \& Reinhold; Hönning No. 1, 98-103 m, Miocene, p. 105.

Fig. 49. Nonion soldanii (D'Orbigny); Vemb No. 1, 284-294 m, Miocene, p. 121.

Fig. 50. Pullenia sphaeroides (D'OrbignY); Grindsted No. 1, 55-60 m, Miocene, p. 123.

Fig. 51. Sphaeroidina variabilis Reuss; Vemb No. 1, $421-431$ m, Oligocene, p. 125.

Fig. 52. Ceratocancris haueri (D’Orbigny); Tönder No. 2, 143-148 m, Miocene, p. 109.

Fig. 53. Uvigerina hosiusi Ten Dam \& ReInhold; Tönder No. 2, 143-148 m, Miocene, p. 128.

Fig. 54. Cibicides $c f$. pseudoungerianus (Cushman); Vinding No. 1, 183-186 m, Miocene, p. 110.

Fig. 55. Epistomina elegans (D'OrbignY); Hönning No. 1, 98-103 m, Miocene, p. 113.

Fig. 56. Elphidium clavatum Cushman, emend. Loeblich \& Tappan, Slagelse No. 1, 12-17 m, ? Interglacial, p. 112.

Fig. 57. Streblus beccarii (LINNÉ); Tönder No. 2, 171-175 m, (? Pliocene-) Miocene, p. 128.

All figures $50 \mathrm{x}$

Phot. J. A. Troels-Smith 


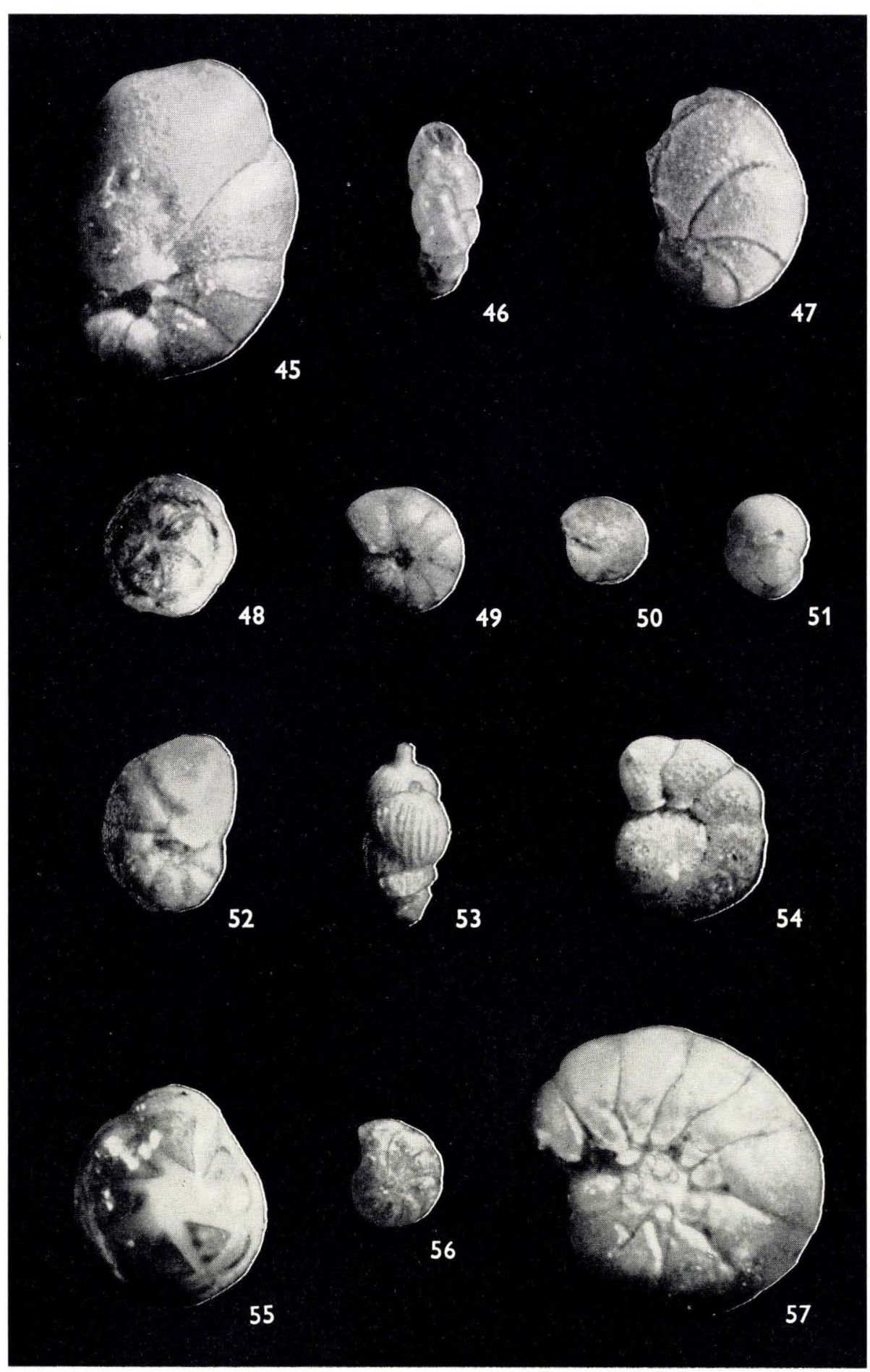


Plate 6.

Fig. 58. Reophax cf. metensis Franke; Vemb No. 1, 1568-1571 m, Dogger, p. 124.

Fig. 59. Epistomina polypioides (EICHENBerG); Fjerritslev No. 2, 445-448 m, Aptian, p. 114.

Fig. 60. Vaginulina harpa Roemer; Vedsted No. 1, 1230-1235 m, Dogger, p. 129.

Fig. 61. Haplophragmoides canariensis (D’Orbigny); Vemb No. 1, 1568-1571 m, Dogger, p. 117.

Fig. 62. Cibicides formosus Brotzen; Flyvbjerg No. 1, 505-510 m, Cenomanian-Turonian, p. 110 .

Fig. 63. Stensioeina exsculpta gracilis Brotzen; Harte No. 1, 678 m, Coniacian-Santonian, p. 127.

Fig. 64. Conorotalites aptiensis (Bettenstaedt); Hönning No. 1,940-945 m, Aptian, p. 111.

Fig. 65. Stensioeina praeexsculpta (Keller); Vemb No. 1, 1341-1344 m, Turonian, p. 127.

Fig. 66. Bulimina aff. truncanella Finlay; Vemb No. 1, 473-482 m, Eocene, p. 108.

Fig. 67. Lagena hauteriviana hauteriviana BARTENSTEIN \& BRAND; Vedsted No. 1, 786-791 m, Hauterivian, p. 117.

Fig. 68. Bulimina midwayensis (CUShMAn \& PARKer); Vemb No. 1, 605-608 m, Paleocene, p. 107.

Fig. 69. Marginulinopsis $c f$. oldenburgensis BARTENSTEIN \& BRAND; Vedsted No. 1, 801806 m, Hauterivian, p. 119.

Fig. 70. Ammovertella cellensis Bartenstein \& Brand; Vedsted No. 1, 870-875 m, Valanginian, p. 101.

Fig. 71. Triplasia emslandensis emslandensis BARTENSTEIN \& BRAND; Vedsted No. 1, 835-840 m, Hauterivian, 30 x, p. 128.

Figure $7130 \mathrm{x}$

Other figures $50 \mathrm{x}$

Phot. Chr. WestergaArd 


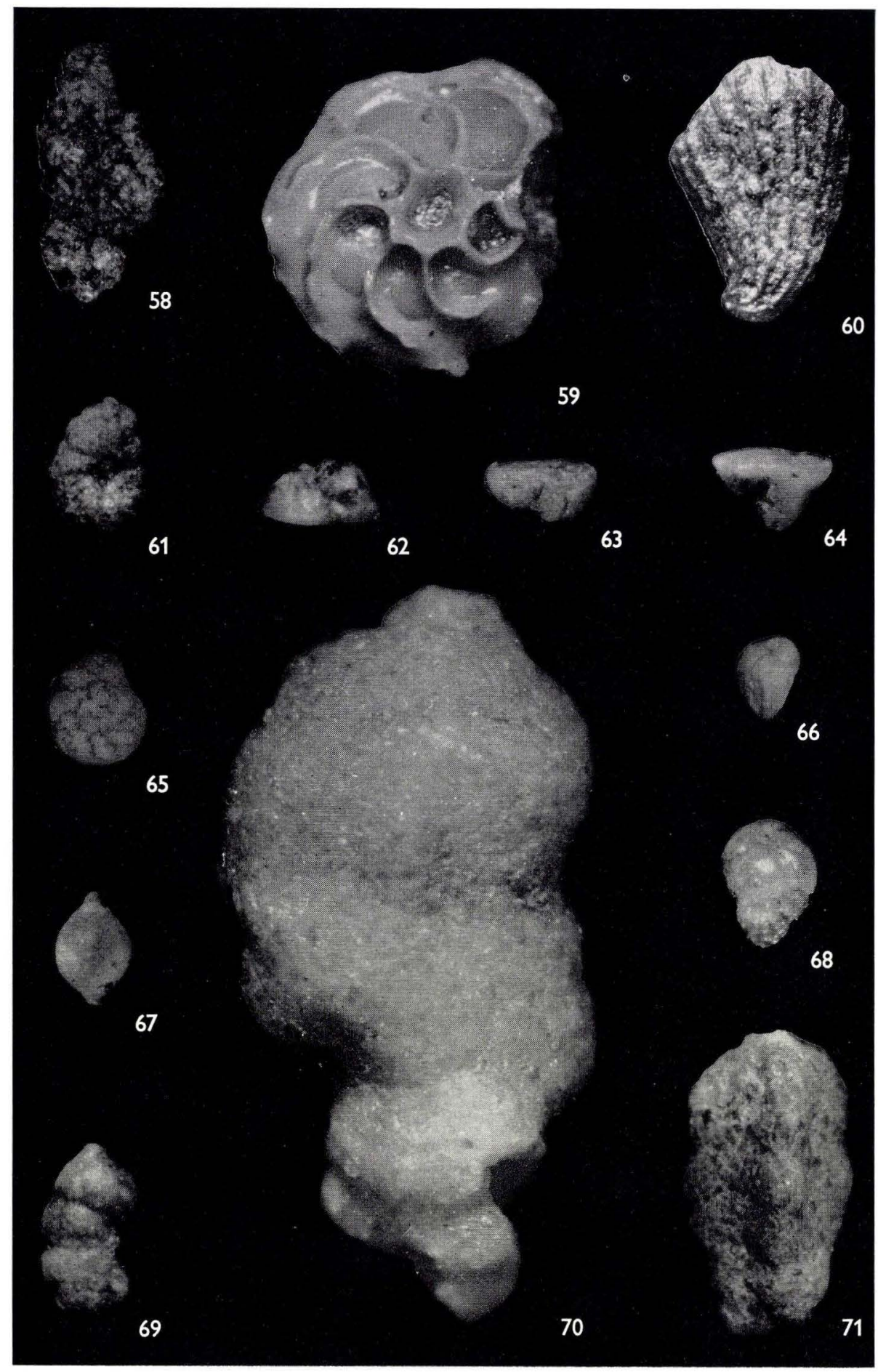




\section{Plate 7.}

Fig. 72. Buchia Fischeri (D'ORBIGNY) 2/1. Right valve and left valve behind in drilling core. Højreskal med bagvedliggende venstreskal i borekerne. Haldager No. 1. 873-879 m. Portlandian, p. 131.

Fig. 73. Oxytoma expansa (PHILliPs) 2/1. Left valve, cast of imprint. Venstreskal, aftryk i borekerne. Börglum No. 1. 983-989 m. Oxfordian, p. 135.

Fig. 74. Cucullaea contracta Phillips 1/1. Right valve. Højreskal i borekerne. Börglum L. No. 1.983-989 m. Oxfordian, p. 132.

Fig. 75. Trigonia hudlestoni LyCET 2/1. Paired valves. Tveskallet eksemplar i borekerne. Haldager No. 1. 1038-1044 m. Oxfordian, p. 137.

Fig. 76. Palaeoneilo galatea D'OrBIGNY 4/1. Damaged paired valves. Beskadiget, tveskallet eksemplar i borekerne. Rödby No. 1; 545 m. Lias, p. 135.

Fig. 77. Palaeoneilo galatea D'Orbigny 3/1. Left valve. Venstreskal i borekerne. Gassum No. 1; 1382-1388 m. Lias, p. 135.

Fig. 78. Pteria contorta (PoRTLOCK) 2/1. Shell bed; relatively well preserved valve at lower right corner. Skallag i borekerne; nederst t. h. forholdsvis velbevaret eksemplar. Vinding No. 1. 1627-1629 m. Rhaetic, p. 137.

Fig. 79. Astarte cf. subdepressa Blake \& Hudleston 2/1. Right valve. Højreskal. Börglum No. 1. 983-989 m. Oxfordian, p. 130.

Fig. 80. Astarte Samanni DE LoRiol 1/1. Fragment of right valve. Brudstykke af højreskal. Börglum No. 1. 832-838 m. Portlandian, p. 131.

Fig. 81. Astarte Samanni DE Loriol 1/1. Same specimen as fig. 80, dorsal view. Samme eksemplar som fig. 80, set fra dorsalsiden. Börglum No. 1832-838 m. Portlandian, p. 131.

Fig. 82. Astarte Samanni DE Loriol 1/1. Left valve. Venstreskal i borekerne. Börglum No. 1. $832-838 \mathrm{~m}$. Portlandian, p. 131. 


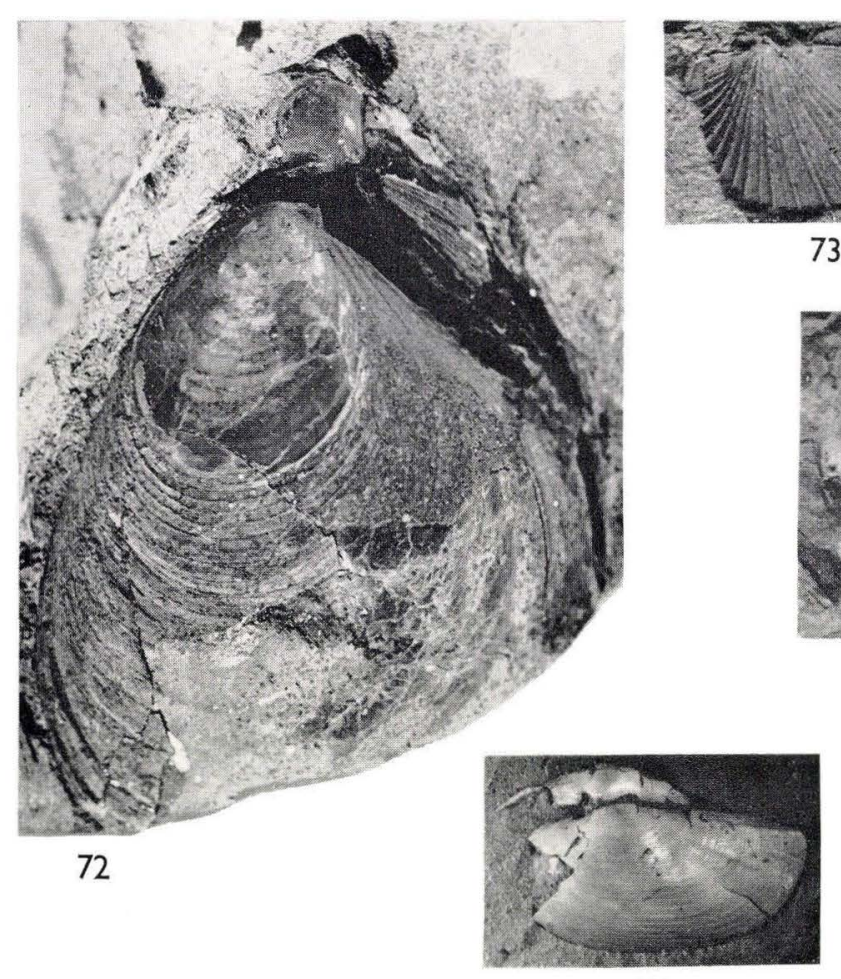

76

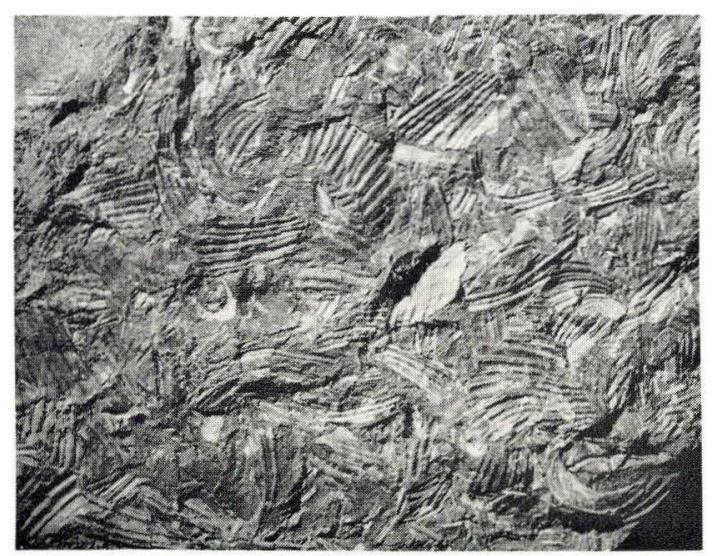

78

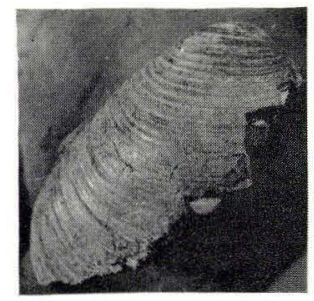

80

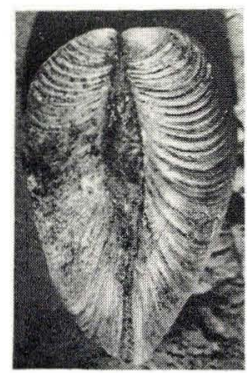

81

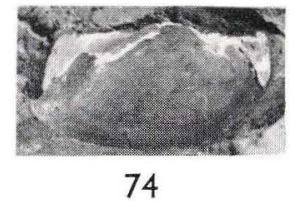

73

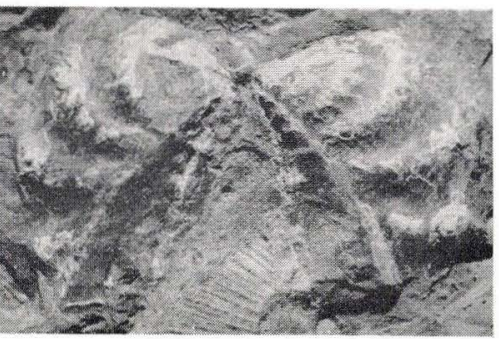

75

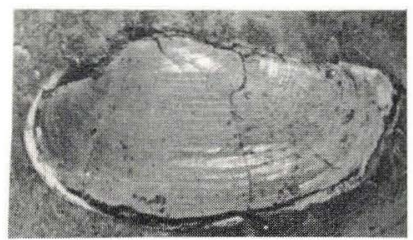

77

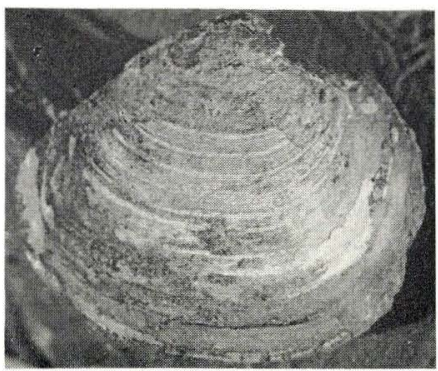

79

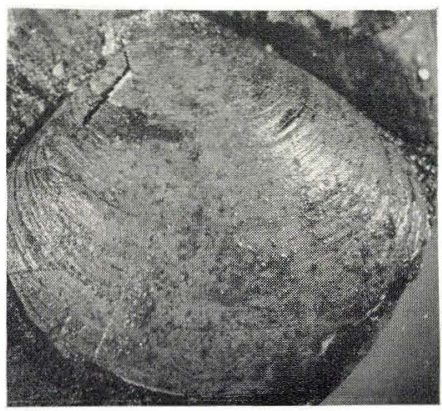

82 


\section{Plate 8.}

Fig. 83. Protocardia morinica DE LoRIol 2/1. Right valve. Højreskal i borekerne. Börglum No. $1.832-838 \mathrm{~m}$. Portlandian, p. 136.

Fig. 84 og 85. Ostrea (Liostrea) delta Sмітн 1/1. Right valve, internal and external view. Højreskal, hhv. inder- og yderside. Börglum No. 1. 983-989 m. Oxfordian, p. 134.

Fig. 86. Borekerne med Buchia Fischeri (D'OrbignY) 1/1. Haldager No. 1. 873-879 m. Portlandian, p. 131.

Fig. 87. Camptonectes lens (J. Sowerby) 2/1. Left valve. Venstreskal. Haldager No. 1. 988-989 m. Oxfordian, p. 131.

Fig. 88. Camptonectes lens (J. Sowerby) 2/1. Right valve. Højreskal. Börglum No. 1. 983-989 m. Oxfordian, p. 131.

Phot. Chr. WestergaArd 


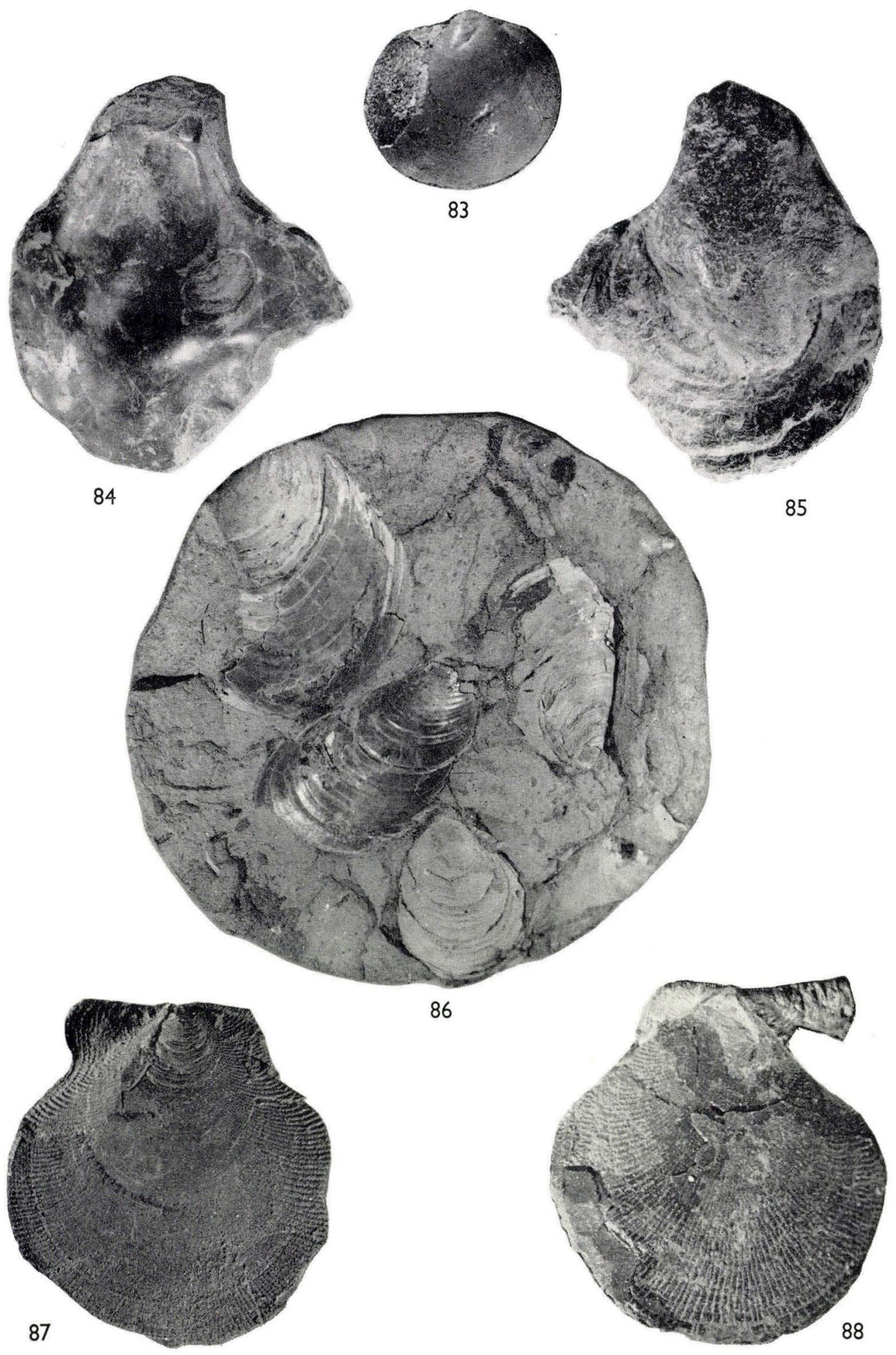


Plate 9.

Fig. 89. Psiloceras planorbis (Sowerby) 1/1. Shell and imprint. Skal og skalaftryk i borekerne. Rödby No. 1.553 m. Lias p. 140.

Fig. 90. Borekerne med Amaltheus margaritatus De Montfort 1/1. Gassum No. 1. 1282$1285 \mathrm{~m}$. Lias, p. 137.

Fig. 91 og 92. Borekerne med Beaniceras cf. centaurus D'OrbignY) 1/1. Rödby No. 1. 546-547 m. Lias, p. 138.

Fig. 93. Psiloceras sp. (Franziceras sp?) 1/1. Gassum No. 1. 1504-1510 m. Lias, p. 46.

Fig. 94. Amaltheus margaritatus DE MONTFORT 2/1. Same specimen as in fig. 90 at right. Eksemplaret t. h. i fig. 90. Gassum No. 1. 1282-1285 m. Lias, p. 137.

Fig. 95. Amaltheus margaritatus DE MontFort 2/1. Gassum No.1.1282-1285 m. Lias, p. 137. Fig. 96 og 97. Schlotheimia angulata (Schlotheim) 1/1. Ventral and left side. Hhv, ventralog venstreside. Gassum No. 1. 1458-1465 m. Lias, p. 140.

Phot. Chr. WestergaArd 


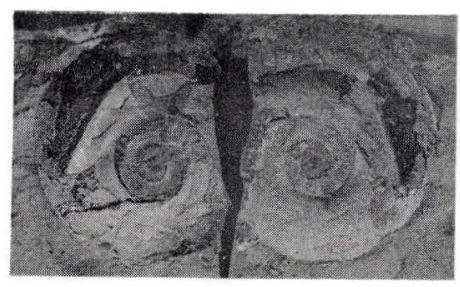

89
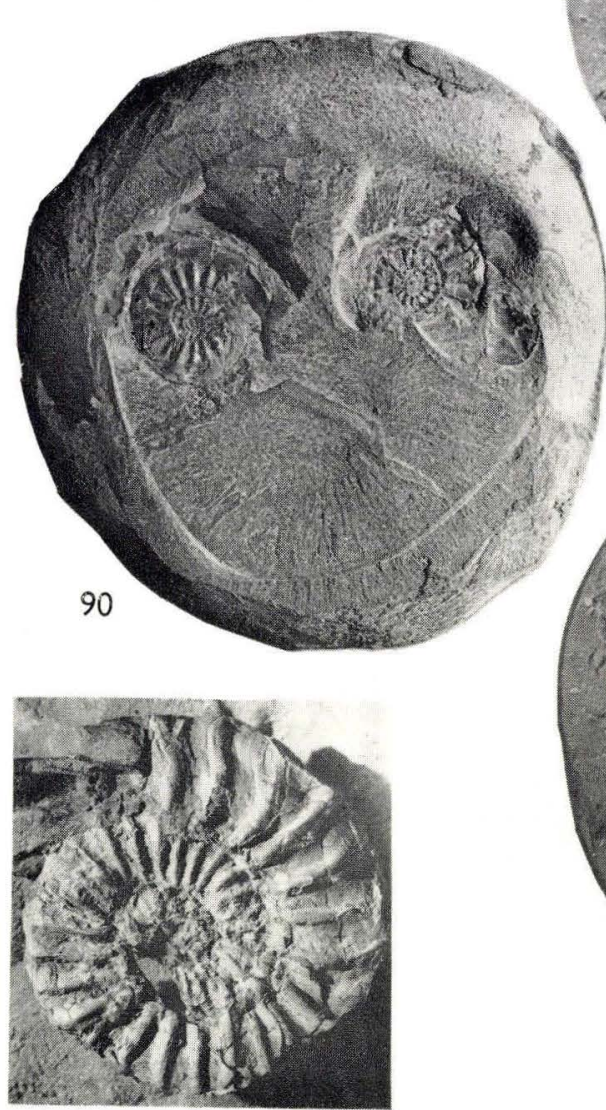

93

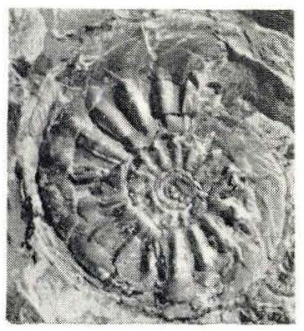

94

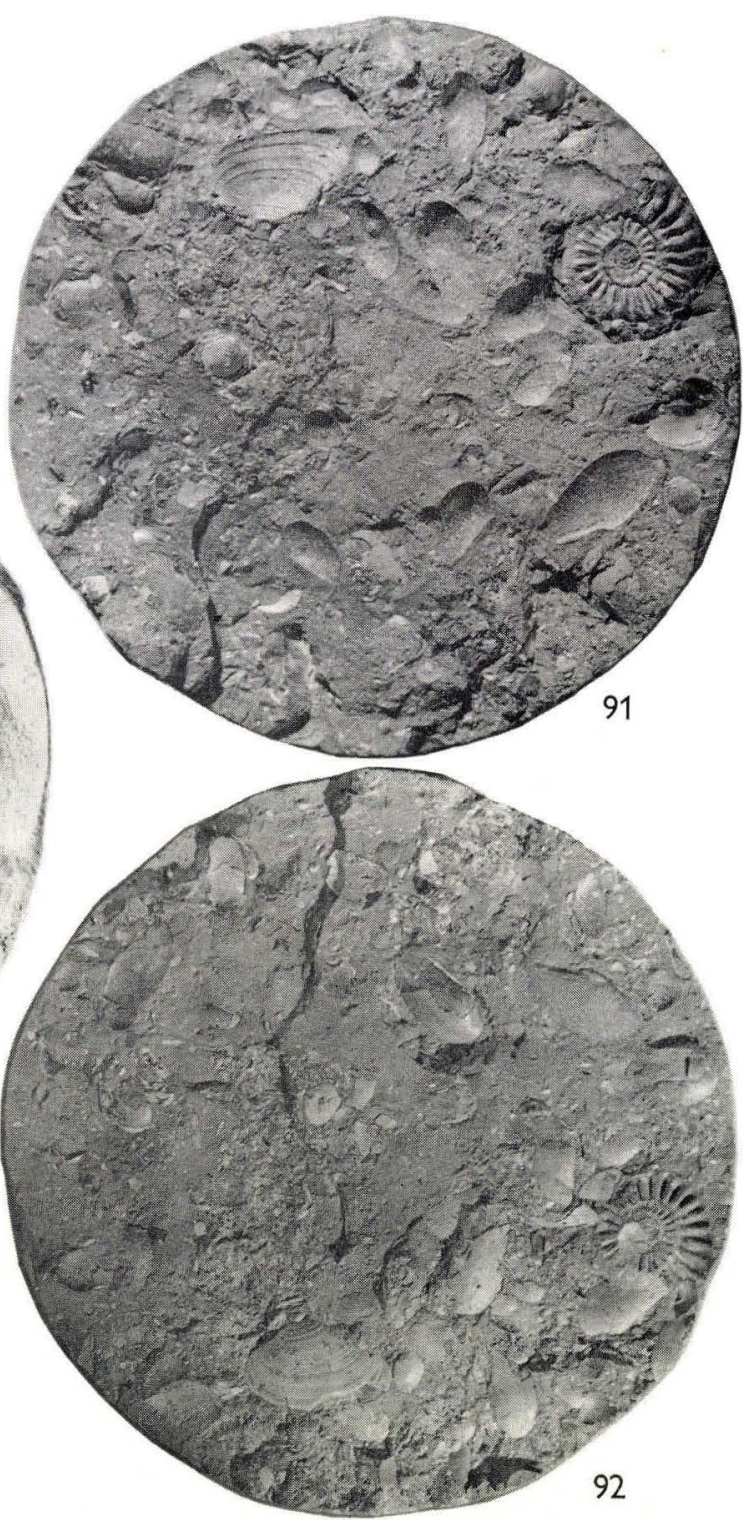

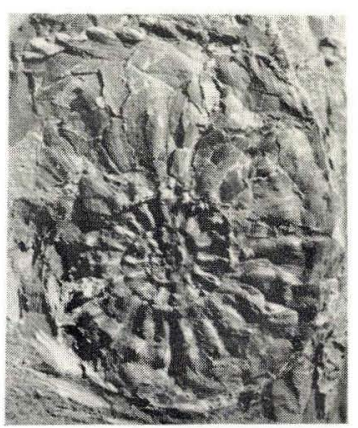

95

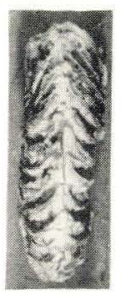

96

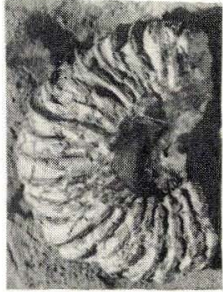

97 
Plate 10.

Fig. 98. Paravirgatites cf. paravirgatus (BuCKMAN) 1/1. Right side. Højre side. Gassum No. 1. 1139-1145 m. Kimeridgian, p. 139.

Fig. 99 og 100. Same specimen from the left and the ventral side. Samme set hhv. fra venstre og fra ventralsiden. 1/1. Kimeridgian, p. 139.

Fig. 101. Parapallasiceras cf. praecox (SchneId) 2/1. Haldager No. 1. 879-885 m. Portlandian, p. 138.

Fig. 102. Lyticoceras noricum (Schlotheim) 1/1. Haldager No. 1. 742-748 m. Lower Cretaceous (Hauterivian), p. 138.

Fig. 103. Lyticoceras noricum (Schlotheim) 1/1. Haldager No. 1. 748-754 m. Lower Cretaceous (Hauterivian). p. 138.

Fig. 104-107. Belemnites (Aulacoteuthis?) magnificus (D'Orbigny) 2/1. Haldager No. 1. 873-879 m. Portlandian. 104 dorsalsiden, 105 lateralsiden, 106 ventralside med fure og lancetformet parti ved apex, 107 tværsnit ved phragmoconen. Dorsal, lateral, ventral, and sectional views, p. 140.

Fig. 108-110. Belemnites (Aulacoteuthis?) magnificus (D’ORBIGNY) 2/1. Haldager No. 1. 873-879 m. Portlandian, p. 140. Fig. 108. rostrum med lancetformet parti, fig. 109 og 110 tværsnit af brudstykker.

Phot. Chr. WestergaArd 

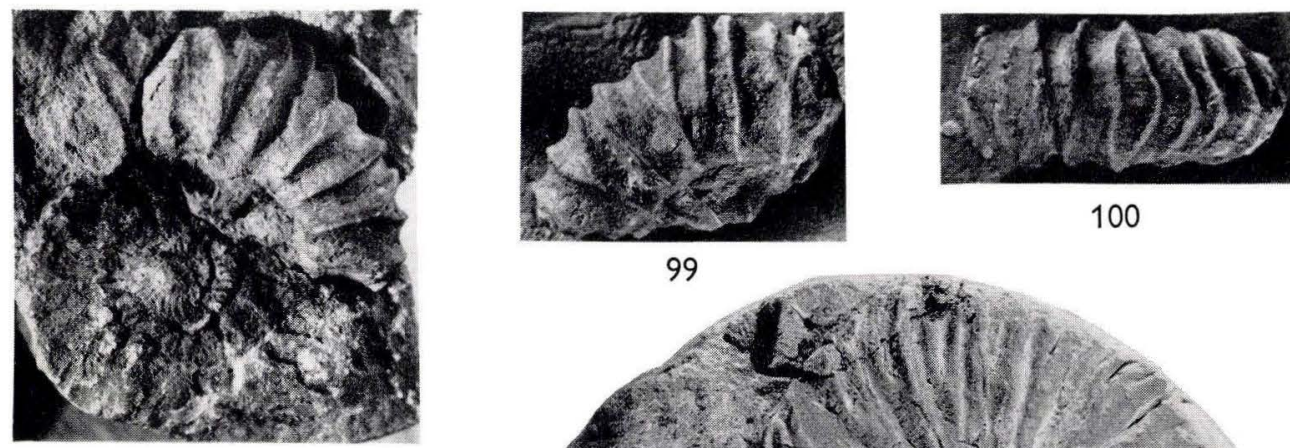

100

98
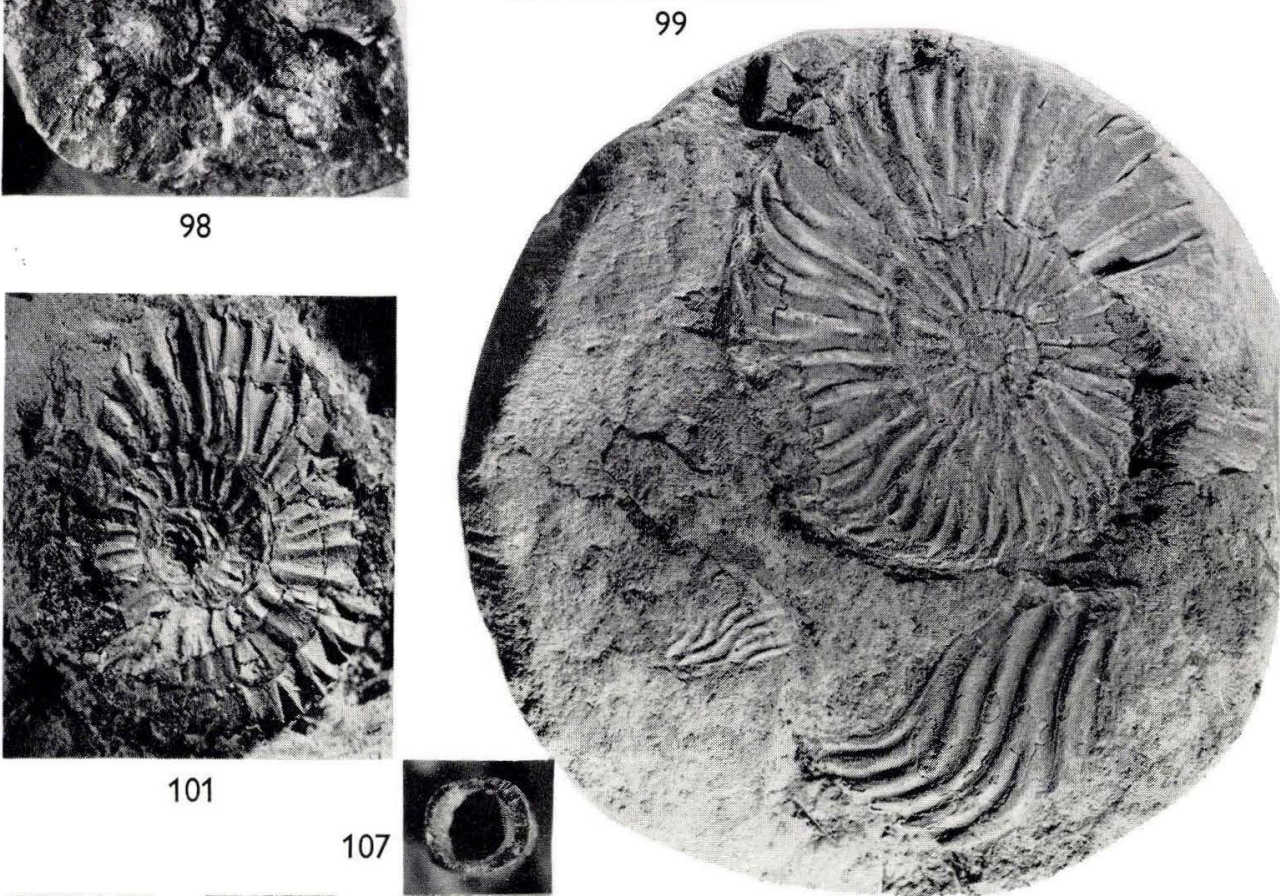

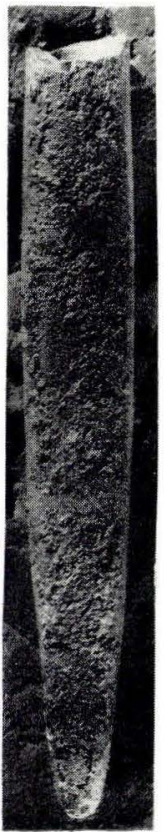

104

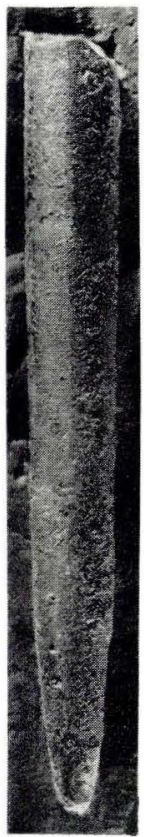

105
107

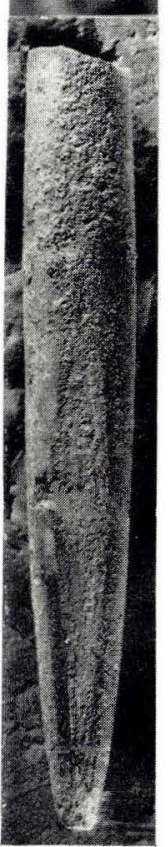

106

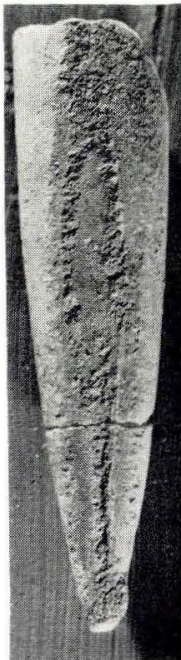

108

102

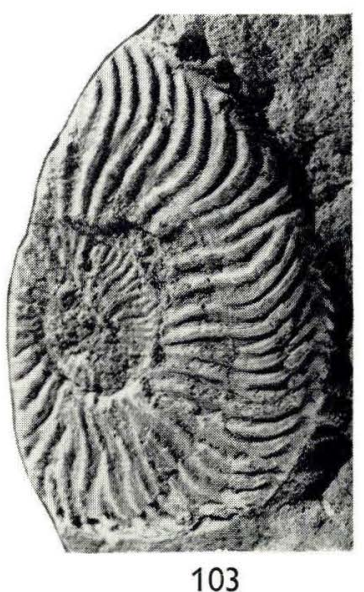

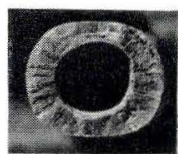

109

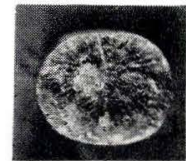

110 
Plate 11.

Fig. 111. Monograptus sp. ca. 10/1. Slagelse No. 1. 2809,2-2810,8 m. Silurian.

Fig. 112. Dictyonema sp. ca. 10/1 Slagelse No. 1. 2767,5-2774,3 m Silurian.

Fig. 113. Monograptus crispus LapwORTH ca. 10/1. Slagelse No. 1. 2809,2-2810,3 m. Silurian., p 130.

Fig. 114. Cladophlebis sp. 1/1. Vedsted No. 1. 2003-2009 m. Rhaet.

Phot. Chr. WestergaArd 
D.G.U. III. Ser. No. 36

Plate 11

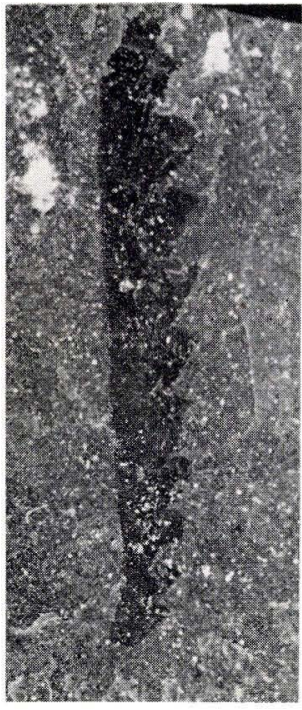

111

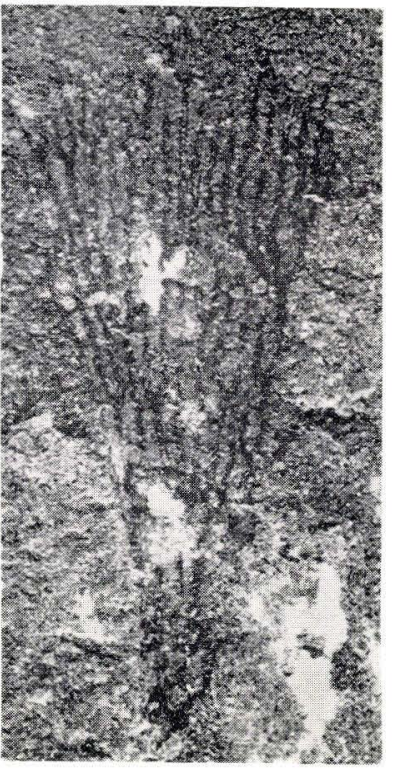

112

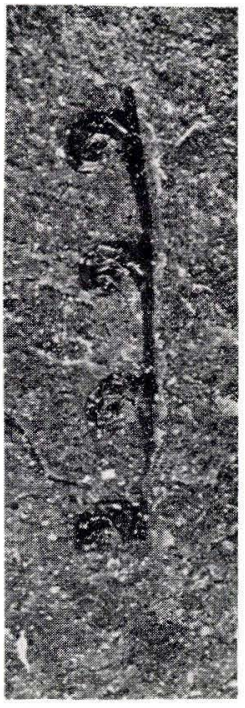

113

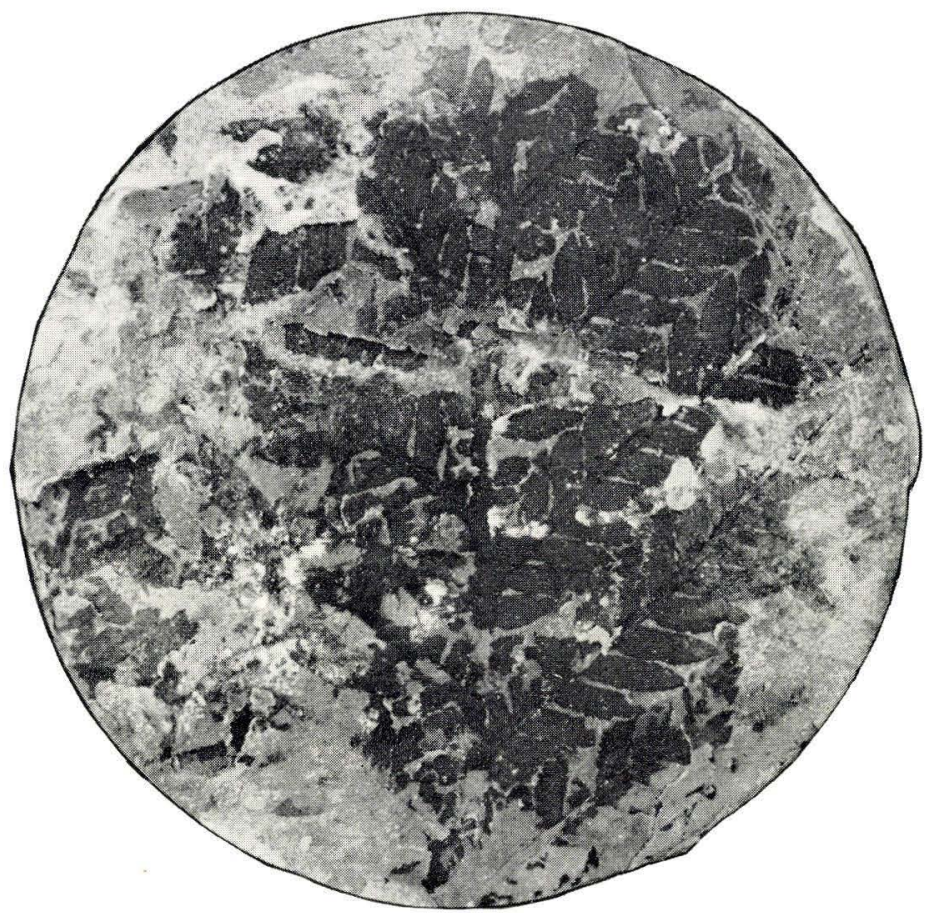

114 
Plate 12.

Fig. 1. The Sullivan rig at Vejrum No. 1, 1946.

Phot. Sigurd Hansen.

Fig. 2. The Cardwell model »R« rig at Arnum No. 1, 1952.

Phot. Leif Banke Rasmussen.

Fig. 3. The Emsco J-750 rig at Tönder No. 2, 1952.

Phot. Gunnar Larsen.

Fig. 4. The Emsco 800 rig at Vemb No. 1, 1958.

Phot. Leif Banke Rasmussen. 


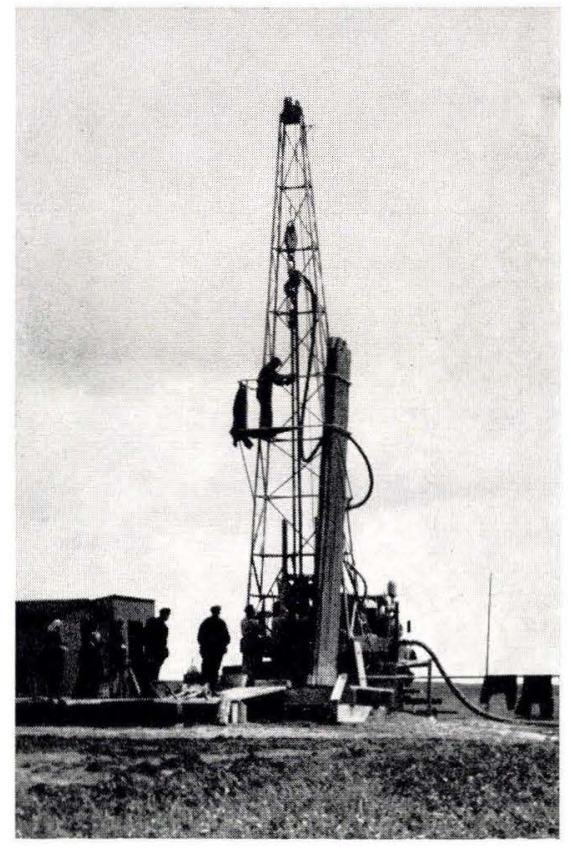

1

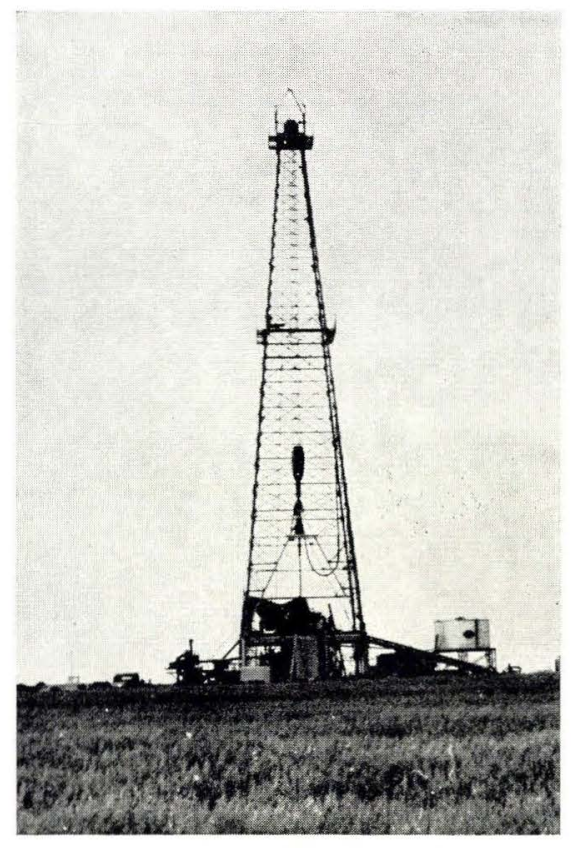

3

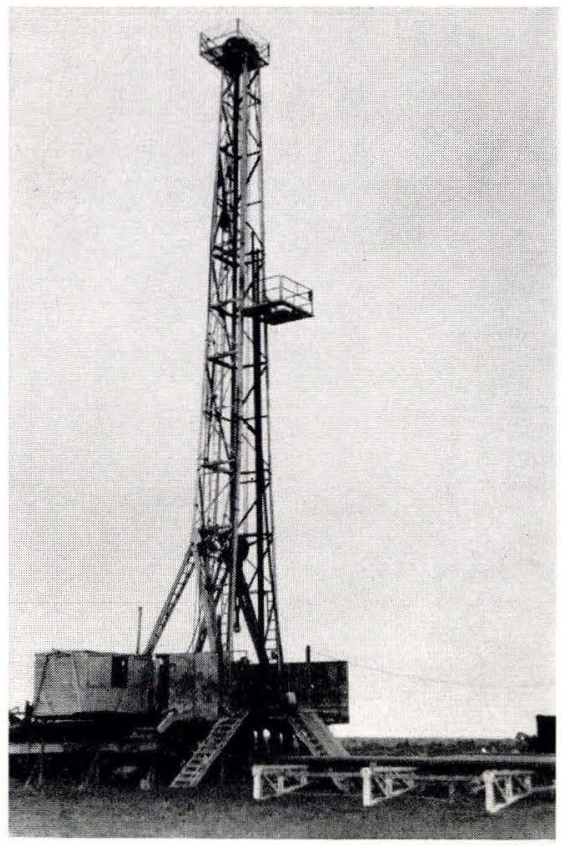

2

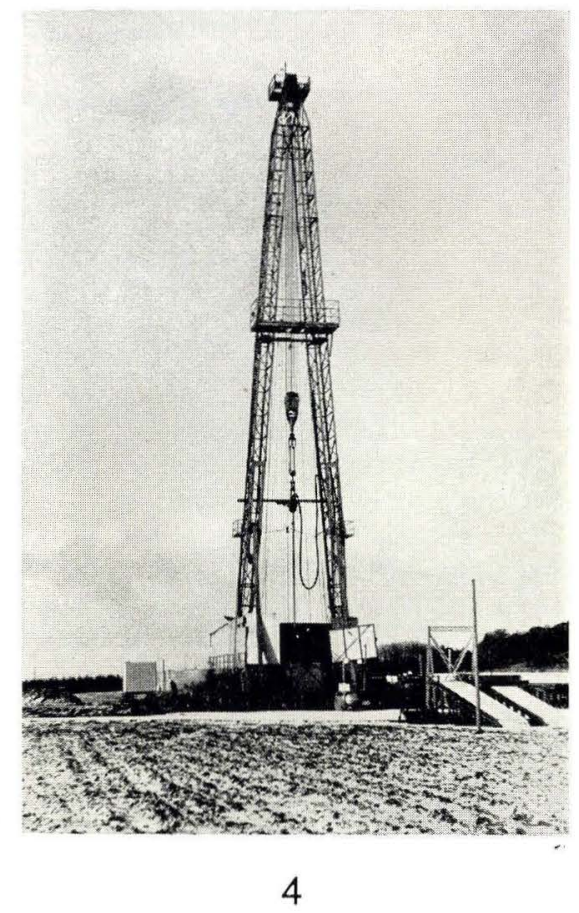


Denne bog er sat med Monotype Times og trykt i 2000 eksemplarer i Andelsbogtrykkeriet i Odense.

Papir: Ekstraglittet 605, 125 g, fra De forenede Papirfabrikker, og Svensk krideret, $100 \mathrm{~g}$. 


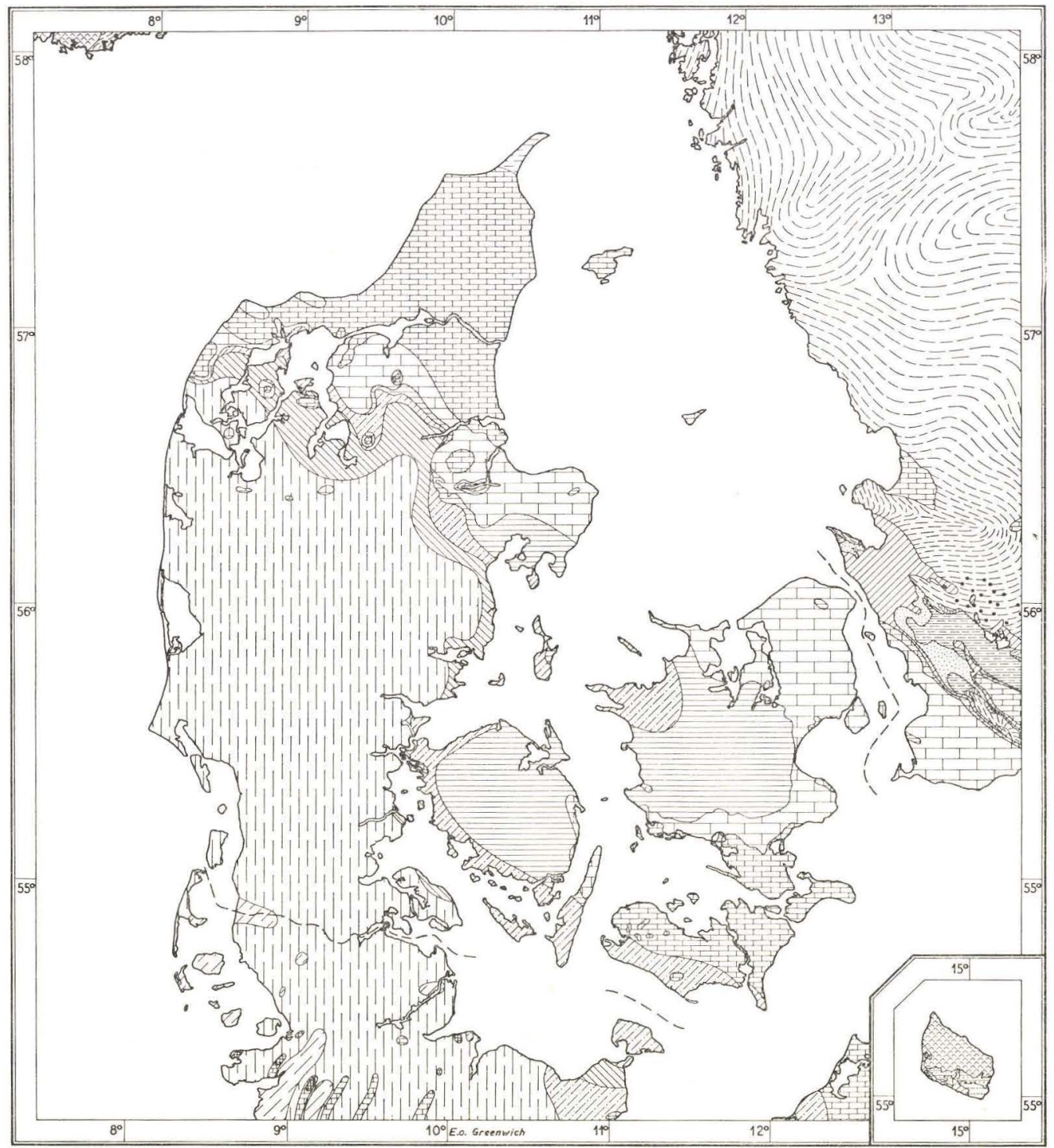

\section{GEOLOGICAL MAP OF DENMARK} FORMATIONS AT THE BASE OF THE PLEISTOCENE
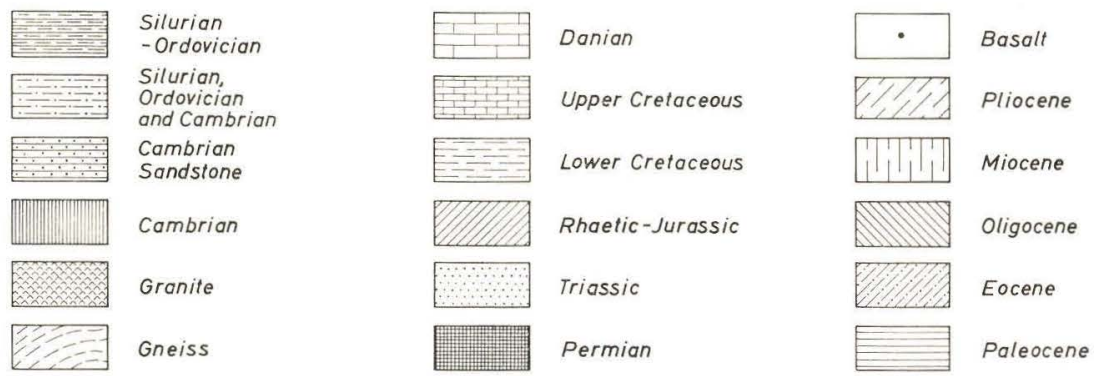

Map scale 


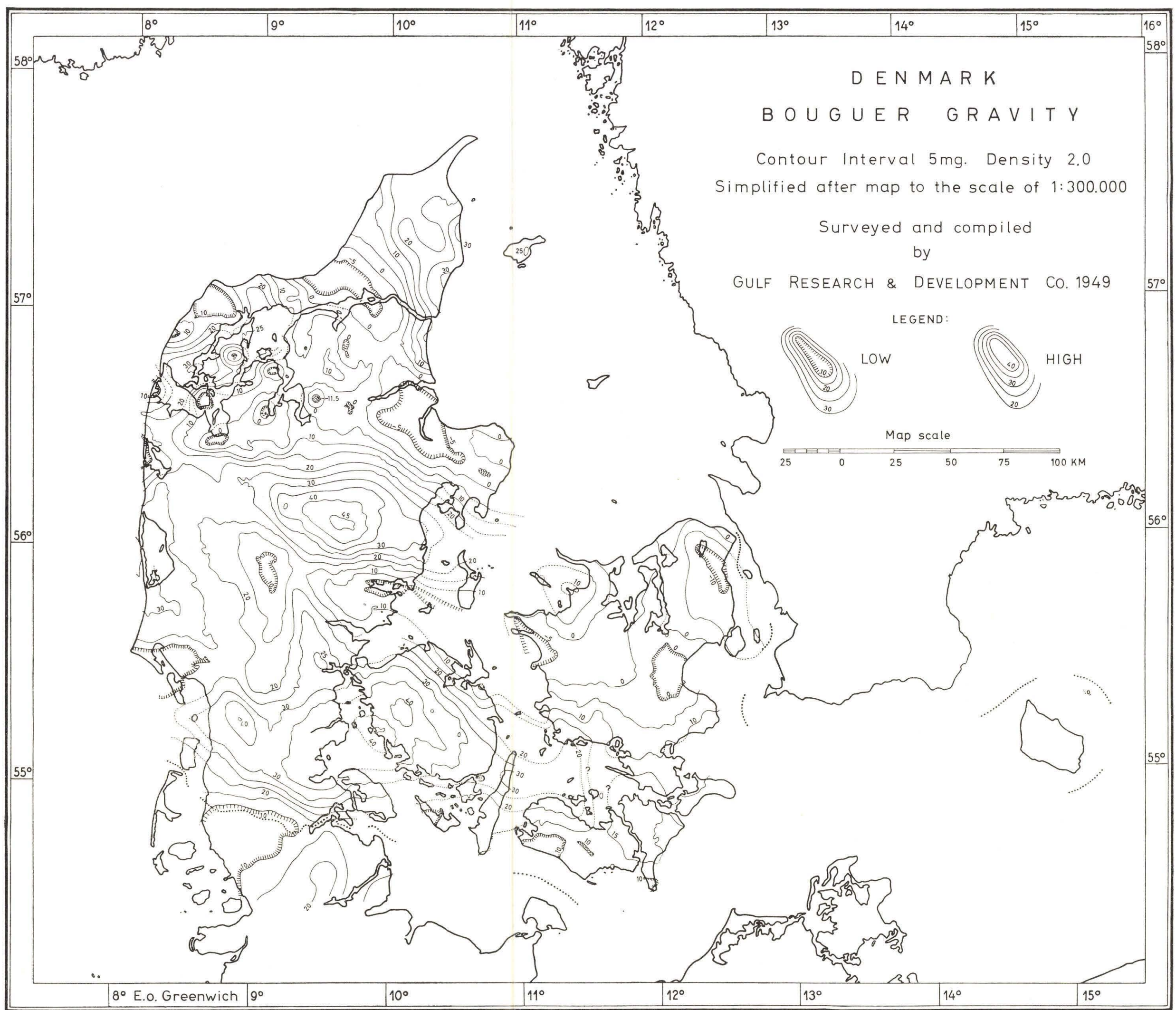




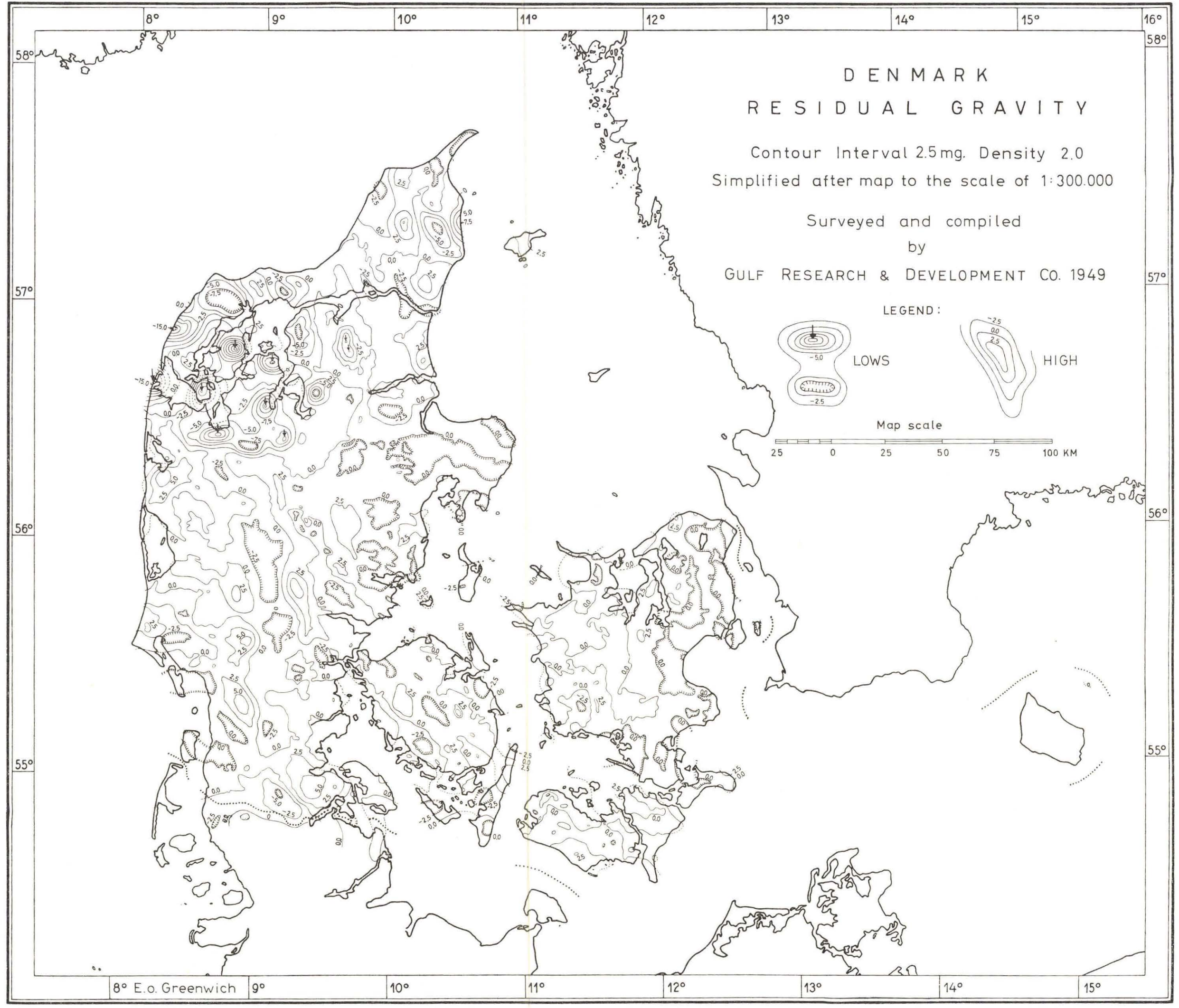

R. Borg del. 


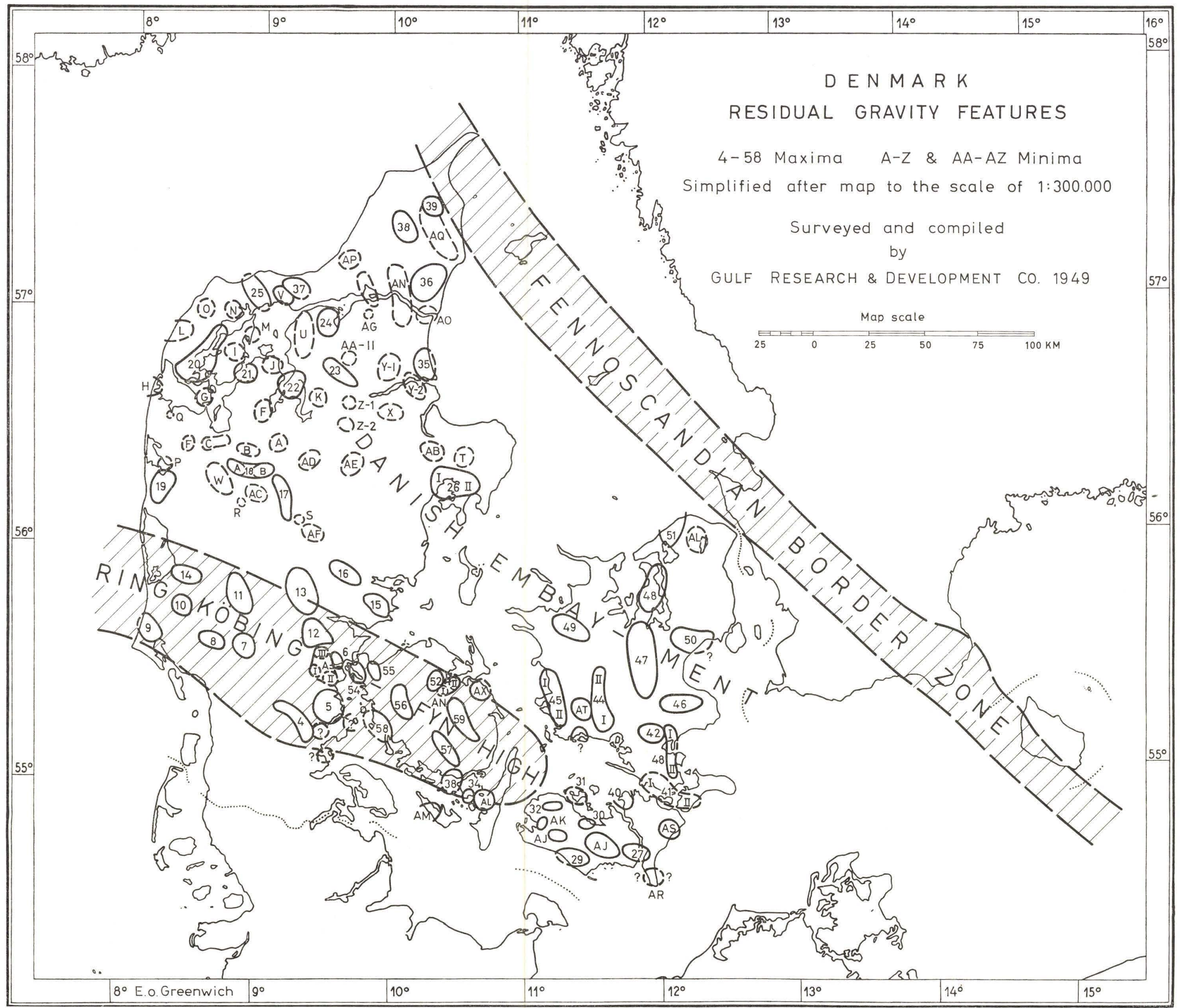

R. BorG del. 


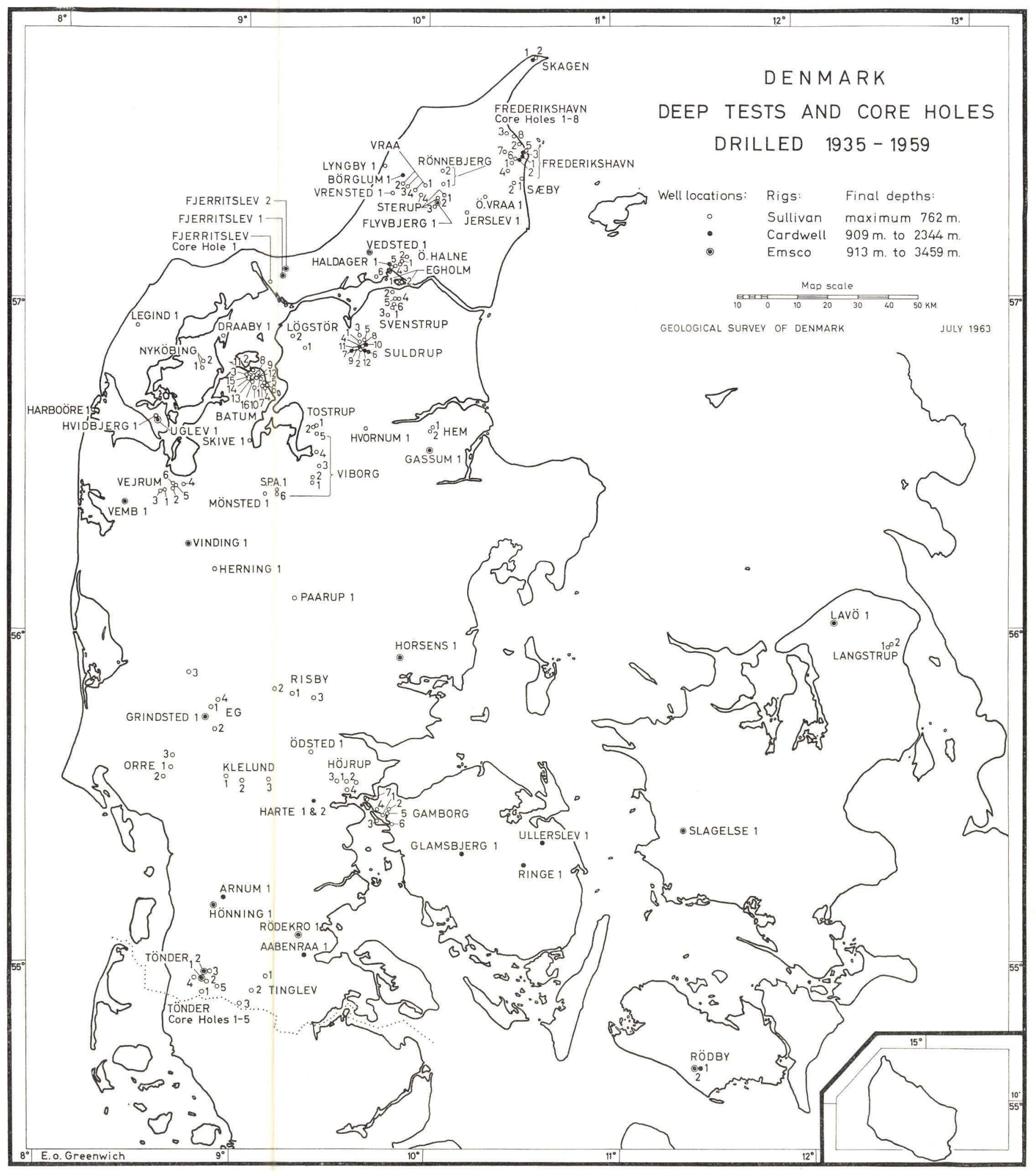

R. BORG del. 


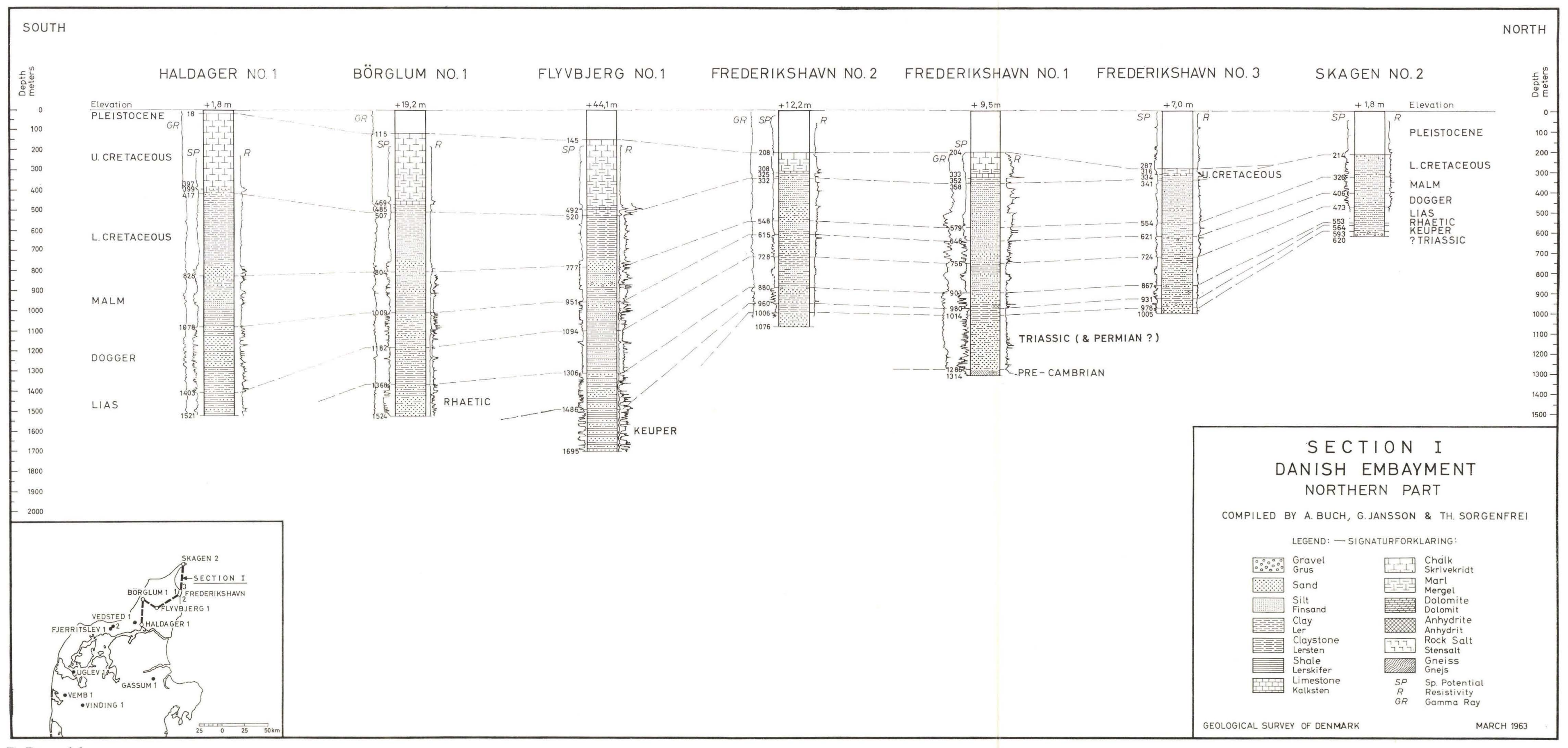

R. Borg del. 


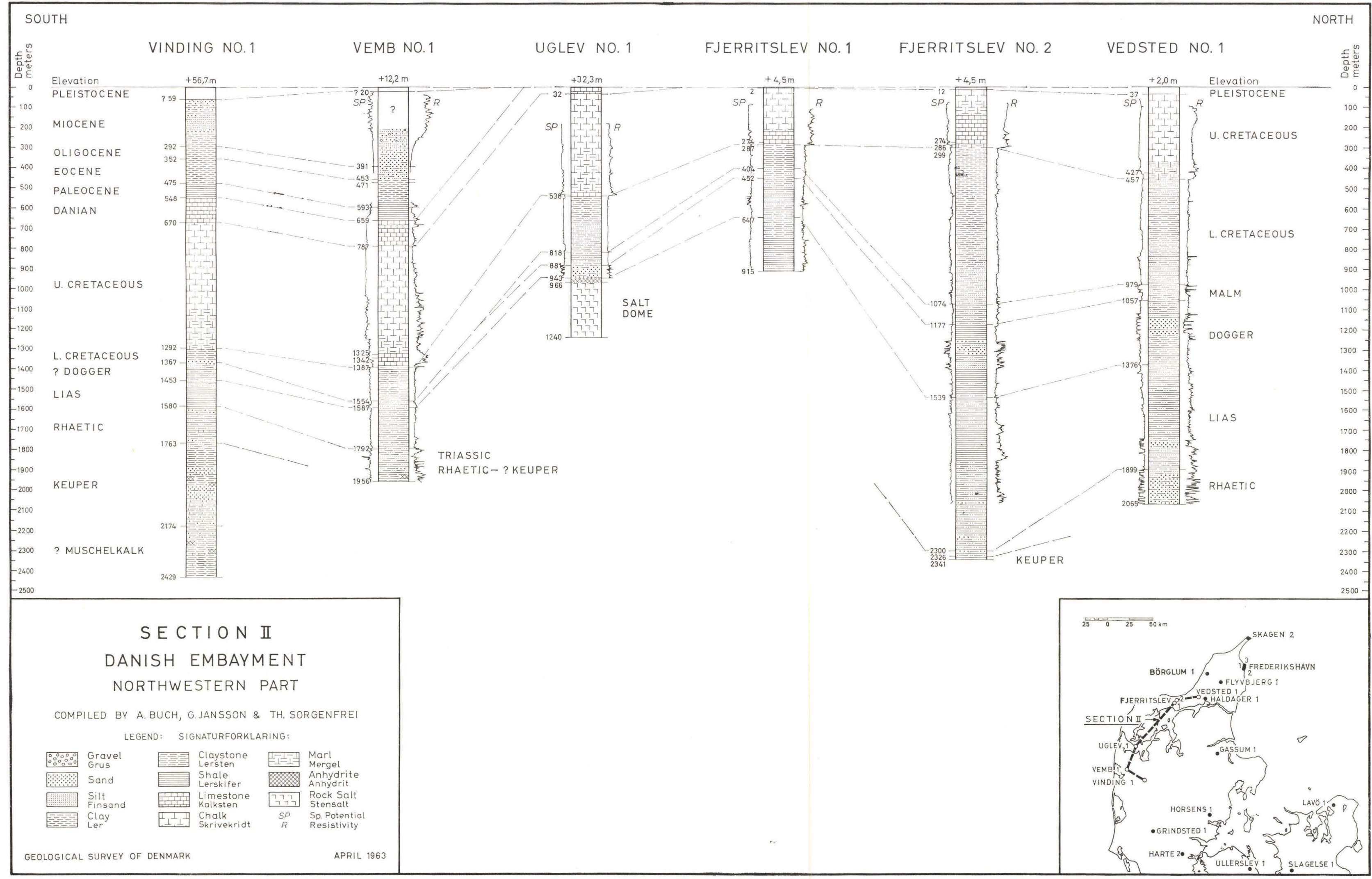




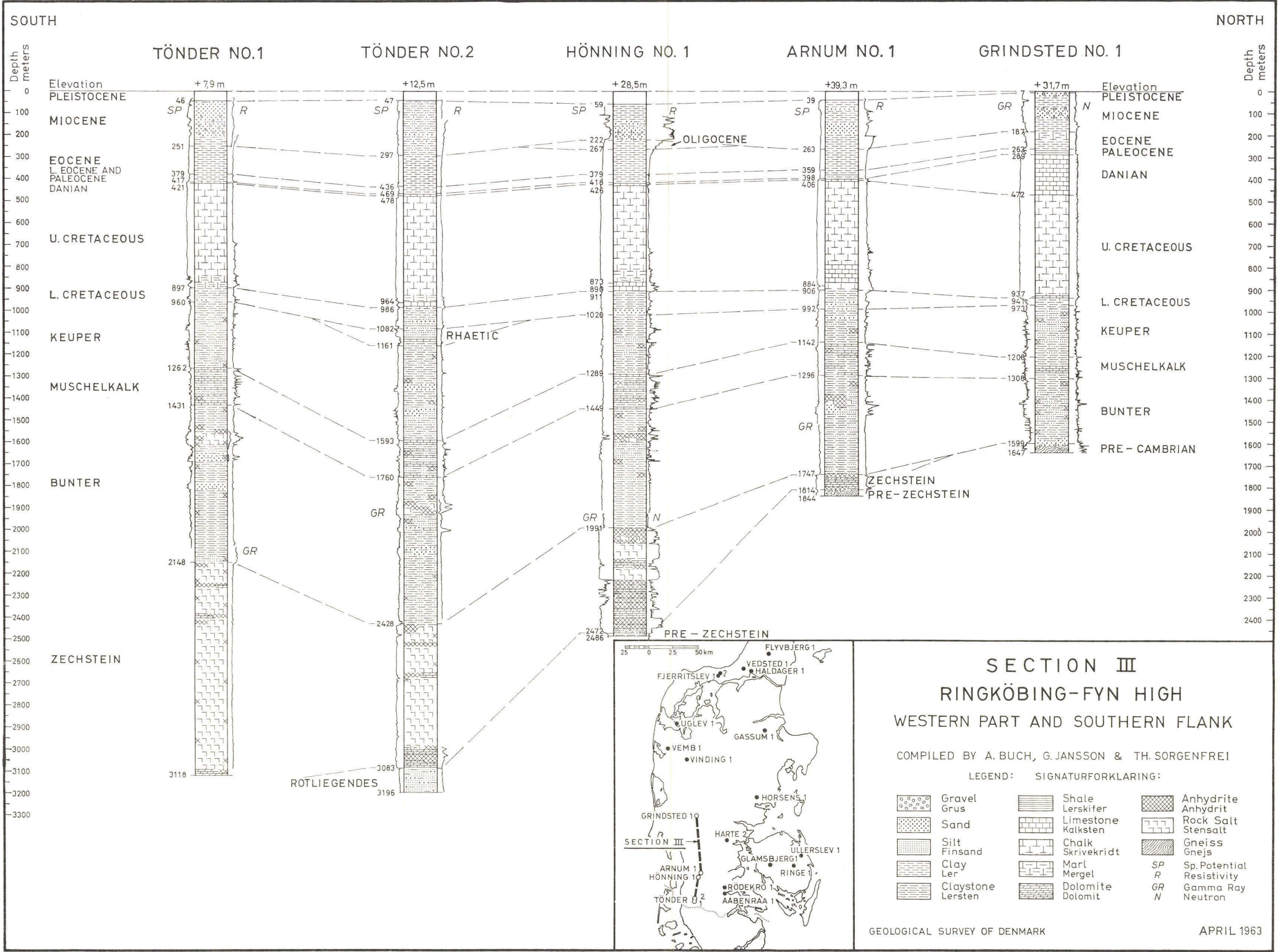

R. Borg del. 


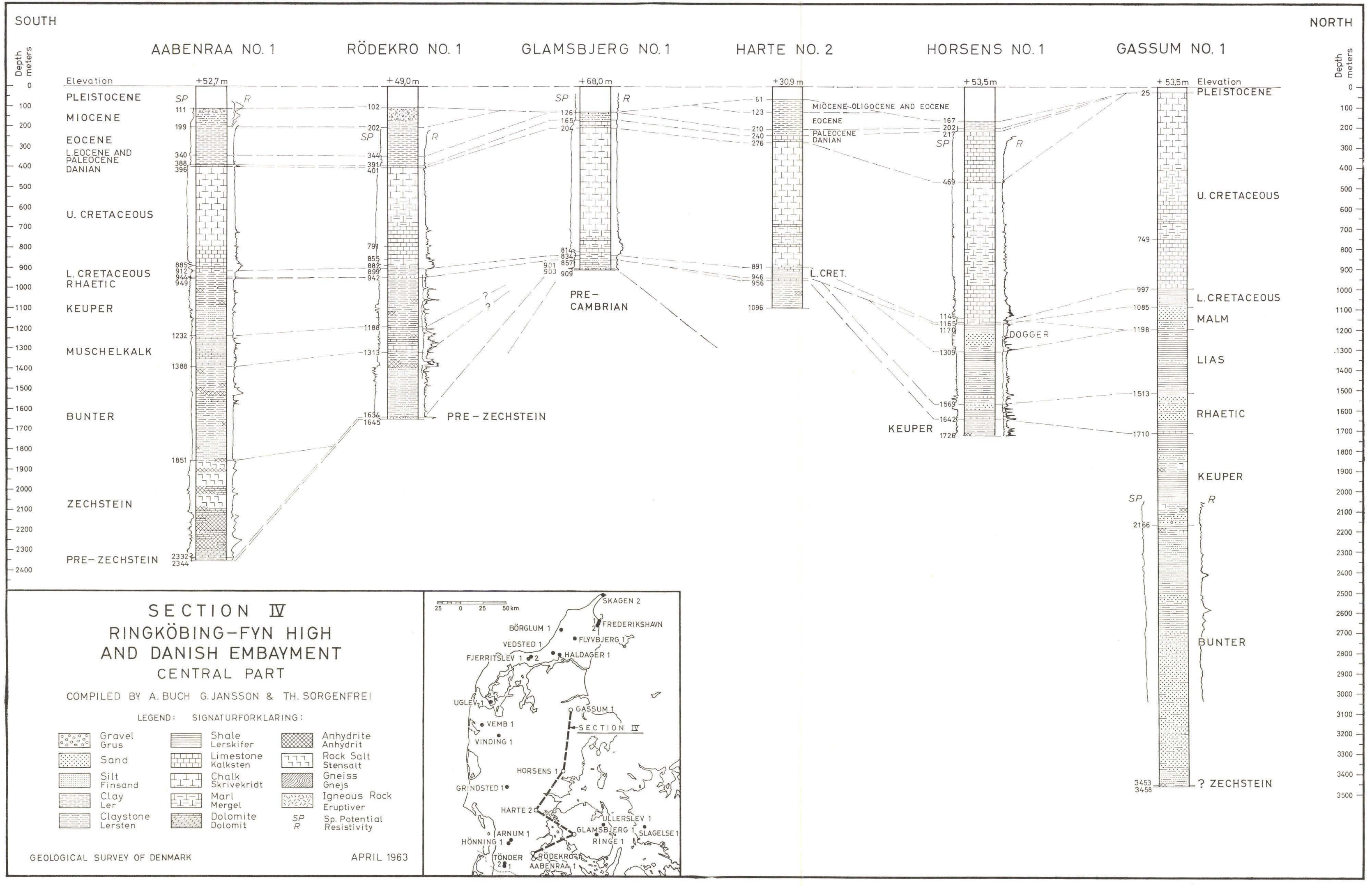

R. Borg del. 


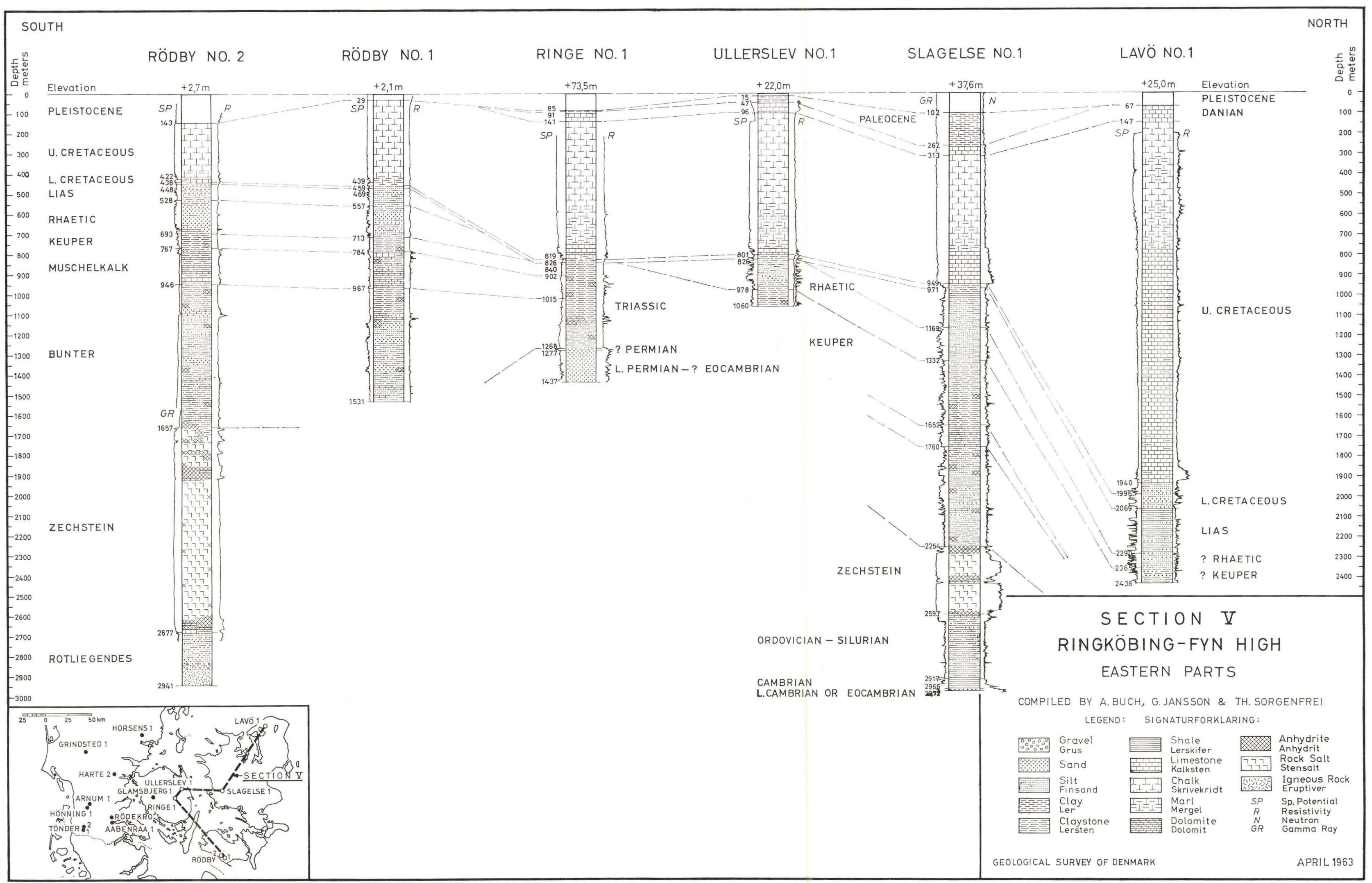

R. Borg del. 